A FULL CATALOGUE AND ANALYSIS OF A COLLECTION OF POSTCARDS

AT THE ART GALLERY OF ONTARIO

DEPICTING SCENES OF TORONTO

by

Brian Piitz,

B.A. York University, 1979

B.A.A. Ryerson Polytechnic (Ryerson University), 1986

\begin{abstract}
A Thesis Project
Presented at Ryerson University and Art Gallery of Ontario

in partial fulfillment of the

Requirements for the degree of

Masters of Arts

In the Program of

Photographic Preservation and Collections Management
\end{abstract}

Toronto, Ontario, Canada, 2013

CBrian Piitz 2013 
I hereby declare that I am the sole author of this thesis or dissertation.

I authorize Ryerson University to lend this thesis or dissertation to other institutions or individuals for the purpose of scholarly research.

\section{Brian Piitz}

I further authorize Ryerson University to reproduce this thesis or dissertation by photocopying or by other means, in total or in part, at the request of other institutions or individuals for the purpose of scholarly research

\section{Brian Piitz}

I understand that my thesis may be made electronically available to the public. 
A Full Catalogue and Analysis of a Collection of Postcards at the Art Gallery of Ontario Depicting Scenes of Toronto

Master of Art, 2013

Brian Piitz

Photographic Preservation and Collection Management

Ryerson University / Art Gallery of Ontario

\section{Abstract}

This applied thesis is focused on the full cataloguing and contextualizing of a collection of one hundred and sixteen postcards at the Art Gallery of Ontario (AGO) depicting scenes of Toronto at the beginning of the twentieth century. Twenty-seven publishers representing international, national and regional manufacturers are identified with their imprint on the verso of the postcard. The applied thesis includes a literature survey discussing a rationale for the cataloguing of postcards, as well as a brief overview of the history of postcards and the history of the urbanization of the City of Toronto. A description and analysis of the AGO postcards provides information about the production cycle of postcards, the scope of commercial photography and the dissemination of photographic imagery in Toronto. The thesis also examines the way images were altered in the production cycle and the manner in which photographers and publishers exchanged photographs intended for postcard production. 


\section{Acknowledgements}

I would like to take this opportunity to thank the many people who offered encouragement, advice and support for the research and completion of my applied thesis. These include my classmates, professors and staff at Ryerson University, the Ryerson Archives, the Art Gallery of Ontario, City of Toronto Archives, the Baldwin Room at the Toronto Reference Library, and the Canadian National Exhibition Archives.

To my first reader, Vid Ingelevics, thank you for your patience and advice, which was so instrumental for the completion of my project.

To Marta Braun my second reader, I have learned so much in the realizing of my project in no small measure to your input.

At the AGO I would like to thank Maia-Mari Sutnik, Curator of Photography for her encouragement; Sophie Hackett, Associate Curator of Photography, for allowing access to the postcards; Liana Radvak, for aiding me to understand and navigate the TMS database.

For their patience and generosity of spirit I wish to thank all my professors: Christopher Evans, Thierry Gervais, Trina Grover, David Harris, Dee Psaila, Michael Robinson and Alison Skyrme. 


\section{Dedication}

This thesis is dedicated to my wife, Marilyn Nazar. Her encouragement and support were steadfast in my decision to continue my studies and the completion of my thesis. 


\section{Table of Contents}

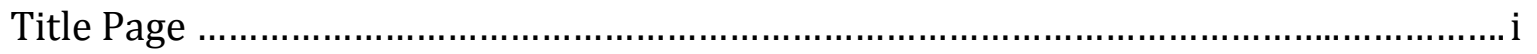

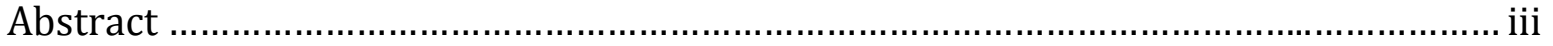

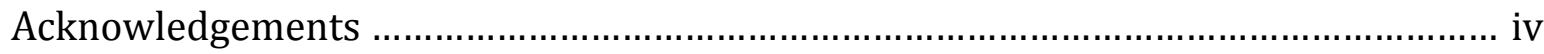

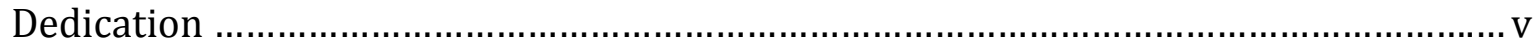

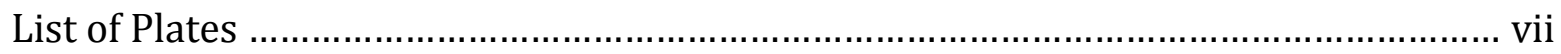

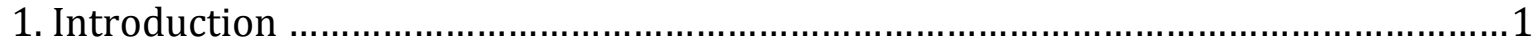

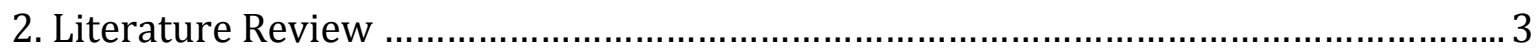

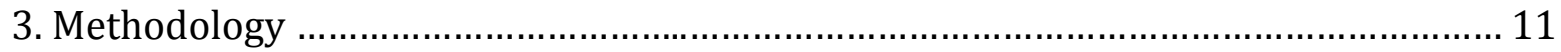

4. Toronto at the Beginning of the Twentieth Century

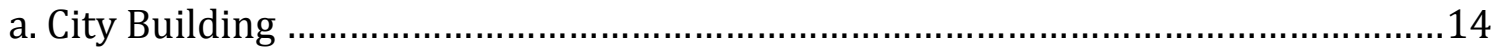

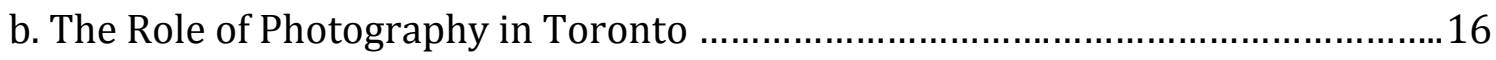

5. AGO Postcards of Toronto: Description and Analysis ....................................... 19

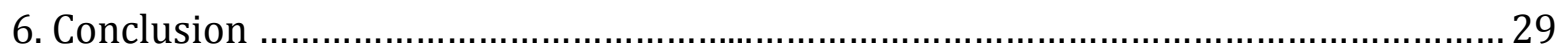

Catalogue of AGO Postcards

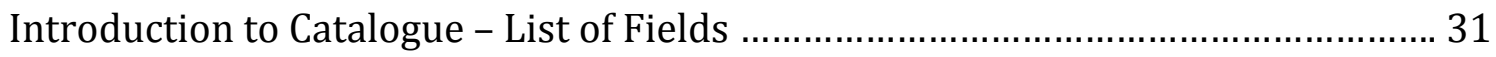

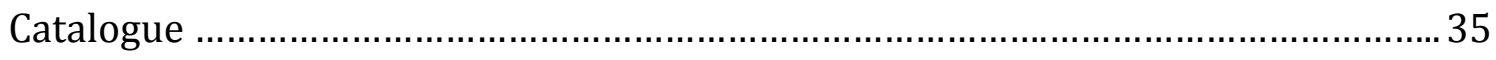

Appendices

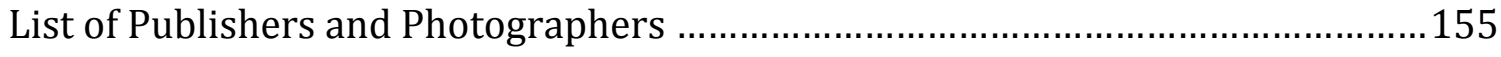

List of Photomechanical Reproductive Processes ............................................ 156

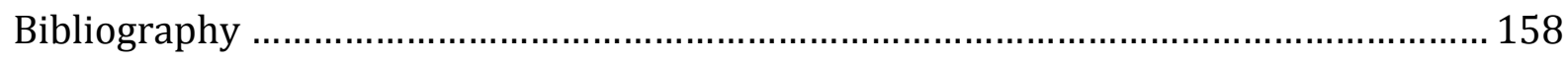

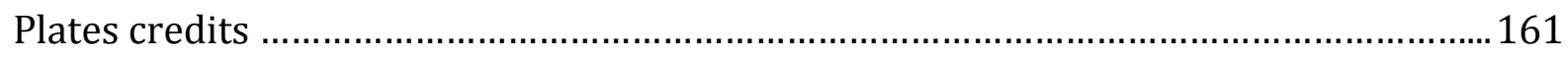




\section{List of Plates}

Figure 1 The Valentine \& Sons Publishing Co. Ltd. Montreal and Toronto, A Glimpse of the Manufacturers' Building, Toronto Exhibition by night. Courtesy of the Art Gallery of Ontario. 24

Figure 2 The Valentine \& Sons Publishing Co. Ltd. Montreal and Toronto, A Glimpse of the Manufacturers' Building, Toronto Exhibition, Canada. Courtesy of the Art Gallery of Ontario. 24

Figure 3 The Valentine \& Sons Publishing Co. Ltd. Montreal and Toronto, "Sunnyside," Toronto, Canada. Courtesy of the Toronto Reference Library.

Figure 4 Valentine-Black Co., Ltd., Toronto, Canada, "Sunnyside," Toronto, Canada. Courtesy of the Art Gallery of Ontario. 25

Figure 5 W. G. MacFarlane Publishing Co. Ltd. Toronto, King Street, Toronto, Canada. Courtesy of the Art Gallery of Ontario.

Figure 6 Raphael Tuck \& Sons, “Oilette,” Toronto, King Street. Courtesy of the Toronto Reference Library. 26

Figure 7 The Valentine \& Sons Publishing Co. Ltd. Montreal and Toronto, York Pioneers House, Exhibition Grounds at Sunset, Toronto, Canada. Courtesy of the Art Gallery of Ontario.

Figure 8 The Valentine \& Sons Publishing Co. Ltd. Montreal and Toronto, York Pioneers House, Exhibition Grounds at Sunset, Toronto, Canada. Courtesy of the Toronto Reference Library.

\section{Catalogue of AGO Postcards}

The catalogue for the AGO postcards contains figures of the recto and verso for each entry

for a total of two hundred and thirty-two figures. 35 to 154 


\section{Introduction}

Although postcards first appeared in the mid-nineteenth century, it wasn't until the beginning of the twentieth century that the craze for collecting of postcards commenced in earnest. The period from 1900 to 1914, the beginning of World War I, is often identified as the "Golden Age of Picture Postcards." It is during this period that economic and sociocultural factors encouraged the exchange and collection of postcards. In Canada, these factors facilitated the publishing of postcards depicting various scenes of the City of Toronto.

In 2011 an anonymous donor gave the Art Gallery of Ontario (AGO) one hundred and sixteen postcards to be added to its Photography Collection. The postcards were published from the 1900 s to 1950 s with a predominant number produced during the first three decades of the twentieth century. The views reproduced on the cards depict public buildings, street scenes and recreational events with forty-one of them showing scenes from the Canadian National Exhibition. In addition the postcards display a variety of techniques used to mechanically reproduce the image on the recto of the card.

This applied thesis entails the full cataloguing and illustration of the one hundred and sixteen postcards currently catalogued using The Museum System (TMS) database software. The objectives of the thesis are to verify and to expand upon the information available in TMS with the aim of encouraging a greater access to the collection by researchers.

My research included visiting the Baldwin Room of the Toronto Reference Library and the Ryerson Archives and the City of Toronto Archives to research information pertaining to the AGO postcards. These visits were undertaken to verify information already present in the AGO TMS database and proved invaluable in contextualizing the AGO 
collection and furthering my understanding of the production of postcards in Toronto at the beginning of the twentieth century.

My thesis incorporates an essay and an illustrated catalogue. The essay portion contains a literature review focused on the history of and cataloguing of postcards, and an account of the methodology employed to produce the thesis. The body of the essay is divided into three sections and expands upon information first offered in the literature review. The first section discusses historical and economic factors related to the City of Toronto and the production of postcards. The second section offers a description and analysis of the AGO postcards and is followed by a conclusion.

The catalogue is the largest component of the thesis. An introduction defines each of the fields employed in the cataloguing process. The catalogue contains one hundred and sixteen records and two hundred and thirty-two illustrations of the recto and verso of each card. Appendix 1 listing the Toronto publishers of the AGO postcards and Appendix 2 offering a brief description of the photomechanical reproduction techniques employed in the production of the postcards precedes the bibliography. 


\section{Literature Review}

\section{Cataloguing Postcards: A Rationale}

By way of introducing a discussion concerned with cataloguing the AGO postcards, I felt it important to consider the basis upon which an image databases may be accessed: postcards are not commonly catalogued at the item level and when they are the catalogue record tends to offer only rudimentary information.

Sara Shatford Layne in her essay, "Some Issues in the Indexing of Images" (1994) notes that the indexing of images should be based on their attributes. She suggests that these attributes be divided into four categories: biographical, subjective, exemplified and relationship. Layne contends that employing these categories will provide access to both individual and groupings of images. Biographical attributes entail objective information related to the creator of the image, time of creation and the geographical location of the depicted subject and the site of production. Subjective attributes combine objective observation and subjective interpretation of the image, list specific and generic descriptions of the image, and record time, space, activities and events. Exemplified attributes distinguish between the subject of the image and the image object. Relationship attributes point to the existence and nature of significant associations between textual and image works. ${ }^{1}$

In Elizabeth Edward's Anthropology \& Photography 1860-1920, Joanna C. Scherer makes the case for the use of photographs as a “... reliable evidence open to analysis and interpretation as seen through the interrelationship of the photographer, subject and

1 Sara Shatford Layne, "Some Issues in the Indexing of Images." Journal of the American Society for Information Science 45, 8 (1994): 584-585. 
viewer."2 She offers a methodology incorporating an analysis of and comparison of photographs with additional images, the intentions of the photographer, the history of photography, the study of ethnographic subjects and how images have been used. Scherer concludes that researchers must review patterns of "subject-matter, symbolic content and composition" of photographs in order for historical photographs to be used as primary data. $^{3}$

A detailed full cataloguing of the Toronto postcards arises from two considerations. The first concerns the increasing use of digital technologies to access archival records. The second is the potential use of picture postcards as source material by urban geographers and others undertaking research related to environmental and socio-economic as well as cultural changes occurring over an extended period of time.

Peter Enser, in "The Evolution of Visual Information Retrieval" (2008), offers an overview of developments related to the theory and practice of image and video retrieval. While he observes that there have been significant developments in cataloguing standards for images and film, he feels that these have been offset by lack of adherence to standards for cataloguing and classification employed by libraries in the management of traditional text based material. ${ }^{4}$ He thus concludes that there is an increasing gap between the practices of researchers and the ability of cataloguers to make databases accessible. ${ }^{5}$

Similarly, in "Providing Subject Access to Images: A Study of User Queries" (1998), Karen Collins analyzed user queries of historical photographic collections at University of

\footnotetext{
2 Joanna C. Scherer, "The Photographic Document: Photographs as Primary Data in Anthropological Enquiry," in Edwards, Elizabeth ed., Anthropology \& Photography 1860-1920, New Haven: Yale University Press, 1992: 32.

3 Ibid, 38.

4 Peter Enser, "The Evolution of Visual Information Retrieval." Journal of Information Science August 34, 4 (2008): 532.

5 Ibid, 541.
} 
North Carolina and North Carolina State Archives. Collins observed that queries to photographic collections exhibit an interdisciplinary approach engaging sociologists, historians, scholars of art and architecture, graphic designers, picture researchers and educators. It must be taken into consideration that any image may potentially be accessed by a wide range of users with differing needs and aims for image use. Given this crossdisciplinary nature of user queries, Collins noted a discrepancy between how researchers query databases and the kind of information entered into databases to be accessed. She writes, "What is really needed is access to images in terms of their generic content, so patrons from any discipline can find images for purposes not predictable by the cataloger."6 She concludes that increased subject indexing beyond what is presently available would lead to greater success of queries by researchers. ${ }^{7}$

Rodney F. Allen and Laurie E. S. Molina in "People and Places on Picture Postcards: A High-Interest Source of Geographic Education" (2004), argue that postcards offer a readily available source of visual information by educators for historical, physical and cultural geographic research. ${ }^{8}$ In "La Cerca y Las Garitas de Ambos Nogales: A Postcard Landscape Exploration" (2001) and again with Nick Burkhart in the essay "Photographic Postcards and Visual Urban Landscape" (2010), Daniel D. Arreola notes that the proliferation of collections of postcards incorporating accessibility and repetition offer an understanding of the historical, cultural and geographical factors affecting an urban environment. The authors note that because postcards depict scenes of interest for tourists and collectors they are often related to zones of commercial activity. Similar scenes photographed by

\footnotetext{
${ }^{6}$ Karen Collins, "Providing Subject Access to Images: A Study of User Queries." The American Archivist 61, (Spring 1998): 51.

7 Ibid, 53.

8 Rodney F. Allen and Laurie E. S. Molina, "People and Places on Picture Postcards: A High-Interest Source for Geographic Education, Journal of Geography 913 (1992): 106-112.
} 
different photographers or the same scene photographed by the same photographer over time can be arranged and analyzed systematically to measure change in the urban environment. ${ }^{9}$

Carol Sawyer and David Butler in their essay, "The Use of Historical Picture Postcards as Photographic Sources for Examining Environmental Change: Promises and Problems"(2010) suggest that postcards are a low-cost alternative to historical photographs for education and research purposes. ${ }^{10}$ However they also report that postcards are not without problems as they are susceptible to distortion by publishers and photographers. Distortions arise due to the colouring in the production of the postcard and with the elimination and addition of visual elements not present in the original photograph. These processes are often employed to disguise photographs taken by someone other than the publisher or to highlight certain elements over others. ${ }^{11}$ Nonetheless the authors contend that because of their abundance in the later part of the nineteenth and early part of the twentieth century, picture postcards afford useful visual data depicting environmental conditions prior to the introduction of aerial photography in the 1950s.

Picture postcards collected by individuals and institutions are often thought of as novelty artifacts evidencing behaviours associated with mass communication and social mores. Arreola and Burkhardt, Sawyer and Butler argue that picture postcards have considerable value as documents of a particular time and space for research purposes in urban geography. This argument can easily be extended to include other disciplines such

\footnotetext{
9 Daniel Arreola \& Nick Burkhart, "Photographic Postcards and Visual Urban Landscape," Urban Geography 31, 7 (2010): 886-887.

10 Carol Sawyer \& David Butler, "The Use of Historical Picture Postcards as Photographic Sources for Examining Environmental Change: Promises and Problems," Geocarto International 21, 3 (September 2006): 74.

11 Ibid, 74.
} 
as the history of architecture and the history of photography. It is within this context that the full cataloguing of the AGO's collection of Toronto postcards is being undertaken.

\section{History of the City of Toronto at the Beginning of the Twentieth Century}

The collection of postcards to be catalogued is comprised of views depicting public buildings, private residences, street scenes and public events located and/or occurring in the City of Toronto in the first few decades of the twentieth century. In order to gather further information on these subjects, I consulted a number of books on the history of the city. Eric Arthur's book, Toronto: No Mean City ${ }^{12}$ and William Dendy's, Lost Toronto ${ }^{13}$ and Toronto Observed ${ }^{14}$ (co-authored with William Kilbourn) offer substantial historical information describing the architectural style, construction and present condition of these buildings. Because a number of cards depict scenes of the Toronto Industrial Exhibition later known as the Canadian National Exhibition (C.N.E.), I consulted books by James Lorimer, The Ex: A Picture History of the Canadian National Exhibition ${ }^{15}$ and Once Upon a Century: 100 Year History of the Ex ${ }^{16}$, published by J. H. Robinson Publishing Ltd. to collect information about the history and development of the C.N.E. from its inception in 1879 as the Toronto Industrial Exhibition and to 1912 when the exhibition became the Canadian National Exhibition. These texts offer a history of the construction of buildings displayed on forty-one of the AGO postcards.

\footnotetext{
12 Eric Arthur, Toronto: No Mean City, Toronto: University of Toronto Press, (1986).

13 William Dendy, Lost Toronto, Toronto: McClelland \& Stewart Inc., (1978).

14 William Dendy \& William Kilbourn, Toronto Observed: Its Architecture, Patrons, and History, (1986).

15 James Lorimer, The Ex: A Picture History of the Canadian National Exhibition, Toronto: James Lewis \& Samuel, Publishers, (1973).

16 Once Upon a Century: 100 Year History of the EX, Toronto: J. H. Robinson Publishing Ltd., (1978).
} 
By way of contextualizing this collection of postcards I considered factors affecting the growth of the City of Toronto at the turn of the century to better contextualize the AGO collection of postcards. A number of sources, including The Canadian City: Essays in Urban and Social History by Gilbert A. Stelter and Alan F. J. Artibise, ${ }^{17}$ offer an overview of ideas related to civic planning and architectural styles in evidence during the period under consideration. The essays, "Visuality and the Emergence of City Planning in Early Twentieth-Century Toronto and Montreal"18 and "Picturing the Professionalization of Planning in Canada, 1901-1927"19 by Sarah Bassnett, offer a discussion of ideas that were to shape the development of Toronto into a modern metropolis.

\section{The History of Picture Postcards}

Richard Carline's book, Pictures in the Post: The Story of the Picture Postcard (1971), ${ }^{20}$ and Frank Staff's, The Picture Postcard and Its Origin (1966), ${ }^{21}$ offer a general historical overview of the picture postcard from its beginnings to the mid nineteenth century. Bjarne Rogan's essay, “An Entangled Object: The Picture Postcard as Souvenir and Collectible, Exchange and Ritual Communication" (2005) ${ }^{22}$ provides an analysis of the cultural impact of the postcard in the modern age. Howard Woody's, "International Postcards: Their History, Production and Distribution (Circa 1895 to 1915)" included in

17 Gilbert A. Stelter, and Alan F. J. Artibise ed., The Canadian City: Essays in Urban and Social History, (1991).

18 Sarah Bassnett, "Visuality and the Emergence of City Planning in Early Twentieth-Century Toronto and Montreal," Journal of the Society for the Study of Architecture in Canada, 32, 1 (2007): 21-38.

19 _ — - "Picturing the Professionalization of Planning in Canada, 1901-1927," Journal of the Society for the Study of Architecture in Canada, 33, 2 (2008): 21-32.

20 Richard Carline, Pictures in the Post: The Story of the Picture Postcard, (1971).

${ }^{21}$ Frank Staff, The Picture Postcard and Its Origin, (1966).

22 Bjarne Rogan, "An Entangled Object: The Picture Postcard as Souvenir and Collectible, Exchange and Ritual Communication," Cultural Analysis, 4 (2005): 1-27. 
Christopher M. Geary's and Virginia-Lee Webb's Delivering Views: Distant Cultures in Early

Postcards offers information regarding the history and production cycle of postcards.

Together these texts contribute insights into the production and role of postcards during

the time frame under review that are applicable to the study of the AGO collection.

More specifically, Mike Filey's Wish You Were Here: Great Postcards of Early Toronto offers a very brief general history of postcards in Canada. ${ }^{23}$ Greetings from Canada: An Album of Unique Canadian Postcards from the Edwardian Era 1900-1916 by Allan Anderson and Betty Tomlinson offers further information but is focused on the use of postcards as a means of communication. ${ }^{24}$

More than two-dozen publishers are identified as producers of the postcards under review. Three of the most noteworthy are the Valentine \& Sons Co. Ltd., the W. G. MacFarlane Publisher \& Importer and the Warwick Bros. \& Rutter Ltd. Printers. Michael J. Smith co-authored texts containing biographical information related to the W. G. MacFarlane and Warwick Bros. \& Rutter companies. ${ }^{25}$ Similar information related to the Valentine and Sons Co. Ltd. and other publishers is available online at The Metropolitan Postcard Club of New York, ${ }^{26}$ the www.archive.hub site in the United Kingdom, The Toronto Postcard site ${ }^{27}$ and at VintagePostcards.ca. ${ }^{28}$ The addition of biographical information to the catalogue offers yet another means to access the postcard collection.

\footnotetext{
${ }^{23}$ Mike Filey, Wish You Were Here: Great Postcards of Early Toronto, Toronto: Greey de Pencier Publications, (1977).

${ }^{24}$ Allan Anderson \& Betty Tomlinson, Greetings from Canada: An Album of Unique Canadian Postcards from the Edwardian Era 1900-1916, Toronto: Macmillan of Canada, (1978).

25 Michael J. Smith, Warwick Bros. \& Rutter Postcard Handbook, Goderich: Michael J. Smith and W.O. (Bill) Buchanan, (2011) \& Smith, Michael J., The W.G. MacFarlane Picture Postcard Handbook, 19021910, Goderich: M.J. Smith, (2010).

${ }^{26}$ Metropolitan Postcard Club of New York, http://www.metropostcard.com/.

27 Toronto Postcard Club (TPC), http://torontopostcardclub.com/.

28 Vintage Postcards of Hamilton, Ontario, http://hamiltonpostcards.com/.
} 
The TMS catalogue records of the AGO postcards list various photomechanical processes for their production. These include chromolithography, collotype, letterpress halftone, photogravure, rotogravure and photo offset lithograph. Relevant information concerning photomechanical reproductive processes is available in Richard Benson's, The Printed Picture. ${ }^{29}$

${ }^{29}$ Richard Benson, The Printed Picture, New York: Museum of Modern Art, (2008). 


\section{Methodology}

On examining the electronic records in AGO's The Museum System (TMS) catalogue of the one hundred and sixteen postcards I observed that some information was missing or incomplete and that information already entered into the database system required verification. When first considered for accession by the AGO's Photography Collection a temporary ID number was assigned to each of the postcards and a document titled "Initial Examination Survey" was completed by the gallery's Art Conservation Department Photography Laboratory. When the donor gave the postcards to the AGO he or she was unable to supply information concerning the production and history of the postcards. At the time I began to work with the cards there had been no research undertaken to add to the existing electronic records.

I began the process of cataloguing the postcards by researching which TMS catalogue fields were pertinent to the cataloguing of postcards, and if information was missing and was required to be moved to other fields. I also examined the postcards for inscriptions and marks that needed to be added to the database.

I consulted the Print Collection Cataloguing Manual developed by David Harris in 2001 for the Mira Godard Study Centre (MGSC), Ryerson University and The Museum System (TMS) database (2012 version) used by the AGO in order to select the appropriate fields to be used. I also considered The Getty Research Institute's online Art \& Architecture Thesaurus ${ }^{\circledR}(\mathrm{AAT})$ and Rules for Archival Description (RAD) to determine the appropriate terminology and format for information to be used for the cataloguing of the postcards.

David Harris developed the manual for cataloguing photographic objects to be used in conjunction with the FileMaker Pro database software employed by the MGSC in 2001. 
The manual stipulates twelve required fields and sixteen optional fields to be used when additional information becomes available. The twenty-eight fields offer a full cataloguing record and are similar to the fields available in TMS. My goal was to select a set of fields similar to the TMS to ensure the easy transference of information electronically to the AGO's database. The resulting catalogue using TMS fields will also exist as a stand-alone reference for researchers. As a result I selected fourteen fields for the cataloguing of the AGO postcards. A description of the fields can be found in the introduction to the Catalogue section of this thesis that follows the Conclusion.

The postcards are presently stored in the Print \& Drawing vault adjacent to the Marvin Gelber Print \& Drawing Centre on the AGO's main floor. The postcards are wrapped in tissue and housed in an acid free, lignin free archival box. As a graduate student in the Photographic Preservation and Collections Management Program at Ryerson University and assigned to the AGO, I was granted access to the vault unaccompanied to examine the postcards.

I first measured each postcard to determine the dimensions of the image and the support and recorded inscriptions and marks on the recto and verso of each postcard. Additionally I examined the image on the recto of each card to determine the photomechanical reproductive process used to print the image and thus confirm information listed in the AGO's "Initial Examination Survey Report".

By way of commencing the research phase of the project I began gathering biographical information related to the twenty-seven publishers of the postcards. Six cards were without a publisher. Additionally I created a list of the subject of each of the postcards and began to gather historical and architectural information that I intended to add to the catalogue. 
I contacted Alan Walker, Special Collections Department, Toronto Reference Library (TRL) to arrange a visit to review their collection of Toronto postcards in an effort to determine if other dates than those offered by postmarks on thirty-seven cards could indicate productions dates. I was able to view photocopies of the cards during my initial visit to the TRL. On a subsequent visit I requested and was able to view a select group of original postcards similar to the AGO postcards. As a result I discovered similar postcards to those in the AGO collection that were produced by different publishers.

On the completion of my visit to the Baldwin Room, I visited the Ryerson University Archives to research information related to four of the AGO postcards showing the Normal School located at St. James Square. The Normal School was located on the grounds of Ryerson Institute of Technology (now Ryerson University). The building was demolished in 1958 and the façade of the Normal School is presently installed on the southern edge of the Ryerson Community Park behind Kerr Hall South. My visit resulted in identifying the photographer for one the AGO postcards. Because of a photograph by Alexander W. Galbraith of the Normal School credited to the City of Toronto Archives discovered in the Ryerson University Archives I contacted and met with Patrick Cummins, the archivist specializing in photographic, cartographic and architectural records at the City of Toronto Archives about the possibility of establishing the identity of other photographers responsible for images used in the production of the AGO postcards. 


\section{Toronto at the Beginning of the Twentieth Century}

\section{a. City Building}

The AGO postcards of Toronto depict public buildings including churches, cultural and educational institutions, street scenes and recreational activities. The earliest card is dated between 1902 and 1910 and the latest between 1955 and 1964. However a predominant number of the cards were produced in the first three decades of the twentieth century. Many of the buildings represented on the cards were constructed during this time, including those located on the Canadian National Exhibition grounds. With my goal of contextualizing the production of the AGO postcards I researched events occurring in the City of Toronto during these years.

Between 1881 and 1921 Canada's urban population increased in absolute terms from 1.1 million to 4.3 million. ${ }^{30}$ This was due in part to migration from surrounding rural areas as well as immigration from Eastern Europe and Asia. In 1871 the British accounted for $95 \%$ of the population of Toronto dropping to $80 \%$ at the beginning of the century. In 1911, manufacturing accounted for $37 \%$, building trades $11 \%$, domestics $10 \%$ and professionals $7 \%$ of the population. By 1931 manufacturing accounted for 20\%, building trades $7 \%$, domestics $4 \%$ and professionals $9 \%$ and hospitality $12 \%$ of the population. ${ }^{31}$

The area encompassed by the city grew substantially during this time as well. Boundaries were extended to incorporate North Rosedale (1906); Deer Park \& East Toronto (1908); West Toronto (1909); Dovercourt \& Earlscourt (1910) and North Toronto

\footnotetext{
30 Paul Ruthford, “Tomorrow's Metropolis: The Urban Reform Movement in Canada, 1880-1920," in Gilbert A. Stelter, and Alan F. J. Artibise ed., The Canadian City: Essays in Urban and Social History, (1991): 435.

31 Statistics Canada, Toronto 150: Portrait of a Changing City, (1984): 11-12.
} 
\& Moore Park (1912). As much as 12,000 acres was added to the city. ${ }^{32}$ As a result of this increase public transportation became an important issue for the municipal government. In 1910 the City of Toronto created the Toronto Civic Railway to service these areas and when the Toronto Railway Company's franchise expired in 1921, the city created the Toronto Transit Commission to service all areas of Toronto. ${ }^{33}$

Many of Toronto's cultural and public institutions were founded at the beginning of the twentieth century. These included the Art Gallery of Toronto (1916-18), later to be renamed the Art Gallery of Ontario, and the Royal Ontario Museum (1910-11). ${ }^{34}$ Toronto underwent significant civic improvements with the construction of its City Hall in 1900, the Prince Edward Viaduct (1915-1919), the R. C. Harris Filtration Plant (planned in 1913 and constructed in 1930) and the High Level Pumping Station (1906). ${ }^{35}$ In the area of health, the Toronto General Hospital moved to its present location at College Street and University Avenue from its eastern location at Gerrard and Parliament Streets in 1914 and the public health nursing service was created in $1908 .^{36}$

Toronto's architecture was greatly influenced in part by the work of Henry Hobson Richardson (1836-1886) and the Chicago School of architecture described below.

Richardson employed the Romanesque style of northern Italy that became known as "Rchardson Romanesque" and can be observed in the construction of Toronto's City Hall,

\footnotetext{
32 Ibid, 11.

33 City of Toronto Archives, "A Commercial City at the Beginning of the 20th Century," http://www.toronto.ca/culture/history/history-1901-50.htm. ${ }^{34}$ Biographical Dictionary of Architects in Canada 1800 - 1950, http://www.dictionaryofarchitectsincanada.org/.

35 Steve Mackinnon, Karen Teeple \& Michele Dale, Toronto's Visual Legacy: Official City Photography From 1856 to the Present, (2009): 106-123.

36 City of Toronto Archives, "A Commercial City at the Beginning of the 20th Century," http://www.toronto.ca/culture/history/history-1901-50.htm.
} 
the Legislative Buildings at Queen's Park and the residential homes on St. George Street. ${ }^{37}$ The Chicago School was known for its use of steel for the construction of commercial buildings and can be seen in the multi-storied Temple Building (1902), the Manufacturers' Building (1902) and the Trader's Bank (1905-06).38

With unprecedented growth the City of Toronto proceeded to attend to issues associated with over crowding, sanitation, housing reform and civic beautification. The early part of the twentieth century also recorded the first enterprises in the area of low cost public housing with the establishment of the Toronto Housing Company in 1914 to build Spruce Court in Cabbagetown and Riverdale Courts east of the Don River. ${ }^{39}$ The Ontario Association of Architects (1889), The Architectural Eighteen Club (1900), The Toronto Guild of Civic Art (1897), the Town Planning Institute of Canada (1919) and the National Council of Women of Canada (1893) promoted ideas related to city planning in an effort to regulate urban growth and to ensure the health and well being of its citizenship. It was generally thought that an efficiently managed and aesthetically constructed city would result in greater prosperity for all the citizens of Toronto. ${ }^{40}$

\section{b. The Role of Photography in Toronto}

In 1910 the City Council of Toronto began an investigation of the management of departments under the control of the City Engineer's Office. As a result, the council reorganized the City Engineer's Office and in 1912 created the Works Department with Roland C. Harris as the Commissioner of Works and City Engineering. The new department

\footnotetext{
37 Arthur, op cit., 166.

38 Ibid, 217-219.

39 Ibid, 183-186.

40 Walter Van Nus, "The Fate of City Beautiful Thought in Canada, 1893-1930," in Gilbert A. Stelter and Alan F. J. Artibise ed., The Canadian City: Essays in Urban and Social History, (1991): 169-170.
} 
incorporated the Photography and Blue Printing Section with Arthur S. Goss as its manager. However, the use of photography to document the department's activities had already started in 1891 through the City Engineer' office. By 1899 photographs were being produced solely by in-house staff. Commercial photographers F. W. Micklethwaite and Josiah Bruce, however, also produced photographs for the city prior to 1899 . The importance of photography to the city's efforts to manage the modernization of Toronto should not be underestimated. By June of 1912 the Photography and Blue Printing Section had produced 1,197 negatives, 4,719 prints and 182 lanternslides. It would continue to produce as many as 6,500 prints each year until $1920 .{ }^{41}$

The number of professional and amateur photographers in the City of Toronto increased from the mid nineteenth century well into the beginning of the twentieth century. Glenn Phillips reports that between 1900 and 1925 there were 507 commercial photographers registered in the city. Of these most were itinerant but 60 photographers had established businesses that endured for at least 10 years or more. ${ }^{42}$ The Toronto Amateur Photographic Association was founded in 1888 and renamed the Toronto Camera Club in 1891.43 The club maintained relationships with international exponents of pictorialism including Alfred Stieglitz, who submitted to its Salons from 1894 onward.44

The Toronto Industrial Exhibition constructed art galleries in 1902 and 1905 in advance of the Art Gallery of Toronto and the Royal Ontario Museum. The 1902 gallery displayed graphic art, photography and applied art. ${ }^{45}$ The Art Gallery of Toronto first

\footnotetext{
41 Mackinnon, Teeple \& Dale, op cit., 87.

42 Glen C. Phillips, The Ontario Photographers List 1901-1925, Volume Two, 2010: 65-83.

43 David Strong, Sidney Carter (1880-1956) and the Politics of Pictorialism, 1994: 51.

44 Ibid, 54.

45 Linda Cobon, e-mail message to author, July 24, 2013.
} 
exhibited photography in 1917 with the $26^{\text {th }}$ Annual Exhibition $\& 14^{\text {th }}$ Salon by the Toronto Camera Club. ${ }^{46}$

At the beginning of the twentieth century the City of Toronto underwent dramatic changes to become a modern metropolis. The increase in population accompanied by shifting demographics and the extension of the boundaries of the city influenced ideas associated with the efficient planning and management of the City of Toronto. The establishment and expansion of important cultural institutions and civic improvements contributed to the continued development of the good health, education and sophistication of the city's citizenry. These changes in the city, the development of amateur and professional photography and its use by the city to manage the urban environment is the context in which we must understand the production and dissemination of picture postcards.

46 Marilyn Nazar, archivist, Art Gallery of Ontario, e-mail message to author, June 19, 2013. 


\section{AGO Postcards of Toronto: Description and Analysis}

The history of postcards begins with the introduction of the Correspondenze Karte (correspondence card) in 1869 in Austria and proceeds to the 1870s and 1880s when cards derived from line drawings and block prints were mass-produced for tourists, promotion and collectors. ${ }^{47}$ Developments in the printing of postcards and changing postal regulations produced discrete historical periods as follows: the Pioneer Era (pre 1898), Private Mailing Card (1898 to 1901), Undivided Back era (1901 to 1907), Divided Back era (1907 to 1915), White Border era (1915 to 1930), Linen era (1930 to 1945) and the Photo Chrome era (1945 to today). The craze for postcards reaches its zenith during the "Golden Age of Postcards" (1900-1914) corresponding to the Divided era. ${ }^{48}$

As early as 1889 a photograph was used in the production of a postcard and Blum and Degan of London and Valentine \& Sons of Dundee incorporated photography to produce postcards as early as $1898 .^{49}$ Images by commercial photographers significantly impacted the quality in the production of postcards. Professional photographers skilled in the composition and production of images displaying sharp detail and tonality were able to produce prints appropriate for the various mechanical reproductive processes used to produce postcards..$^{50}$ The earliest mechanical reproductive process employed in the production of postcards was the collotype. ${ }^{51}$ With the introduction of rotary presses in 1905 and the lithographic offset press in 1908 high quality postcards employing

\footnotetext{
${ }^{47}$ Howard Woody, "International Postcards: Their History, Production, and Distribution (Circa 1895 to 1915)," in Christraud M. Greary \& Virginia-Lee Webb eds., Delivering Views: Distant Cultures in Early Postcards, (1998): 14-15.

48 Ibid, 21.

49 Mike Filey, Wish You Were Here, (1977): 1.

50 Woody, op cit., 16.

51 Richard Benson, The Printed Picture, (2008): 244-246.
} 
photographic images were produced in the millions. By 1905, seven billion cards had passed through the world's post offices. ${ }^{52}$

The production cycle of postcards began with an individual known as a jobber or drummer acting as sales person for regional, national and international distributor and manufacturers of postcards. It is through the jobbers that the retailers arranged with wholesalers for the production of postcards according to specifications. In some instances a single company assumed the roles of publisher, printer and distributor of postcards. Individual entrepreneurs, independent printers and publishers of educational texts who saw the potential profits arising from the postcard craze began to produce or commission their own photographs for postcard use..$^{53}$

The AGO postcards reveal a similar history to the production and distribution of postcards internationally. Twenty-seven publishers are identified on the verso of one hundred and ten of their postcards. Of the twenty-seven publishers, seventeen were local or regional, six national and four international publishers of postcards. The Valentine \& Sons Publishing Co. Ltd, of Montreal and Toronto (1903-1922) established by Valentine of Dundee Ltd. of Scotland also maintained offices in South Africa, Australia, America and Norway as well as Canada. According to one account, the Valentine \& Sons Co. Ltd. produced twenty thousand views of Canada. ${ }^{54}$ Over eight hundred of these views are of Toronto. ${ }^{55}$ Valentine \& Sons Company is represented by fifty-one postcards in the AGO collection. Other contributors to the AGO collection are the Warwick Bro's \& Rutter,

\footnotetext{
52 Rogan, op cit., 4.

53 Woody, op cit., 23.

${ }^{54}$ Anderson, Allan \& Betty Tomlinson, Greetings from Canada: An Album of Unique Postcards from the Edwardian Era 1900 - 1916, (1978): xii.

55 Toronto Postcard Club (TPC), http://torontopostcardclub.com/canadian-postcard-manufacturerlists/valentine-and-sons-of-dundee/.
} 
Limited, Printers (8), W. G. MacFarlane Publishing Co. Ltd. (6), the Royal Specialty Sales Co. (5), and The Post Card \& Greeting Card Co. Ltd. (4). Gardiner, Thomson \& Bowles, the Kiwanis Club of West Toronto, the Photogelatine Engraving Co. Ltd., Souvenir Post Card Co. and the Valentine-Black Co. Ltd are each represented by three postcards. The Canadian View Card Co. and the E. Zaitchick, Canadian National Exhibition are represented by two postcards each. The remaining identified publishers are represented by one card each. (See Appendix I for a full list of publishers).

Three events shaped the production and dissemination of postcards in Canada at the beginning of the twentieth century. In 1903 the relaxation of Canadian postal regulations lead to the introduction of the divided back postcard. ${ }^{56}$ The divided back allowed for both the message and the address to be written on the verso of the card and increased the demand for postcards to be sent through the mail. Publishers were encouraged to invest in the production of postcards and the W. G. MacFarlane and Warwick Bro's \& Rutter are two of the earliest firms to take advantage of the new regulation. The second is the passing of the Payne-Aldrich Act of 1909 by the United States. The act imposed a tariff on foreign items, including postcards, entering the United States. The result was to create a glut of postcards as sponsors and jobbers stocked up on cards before the act was to take effect leading to a decline in the price of postcards in the United States. Access to the American market plus the decline in price of cards greatly reduced the postcard production in Canada. It seems that the W. G. MacFarlane Co. ceased production of cards in 1910 in part due to the act. ${ }^{57}$ Finally, World War I curtailed production of postcards worldwide. Many publishers including those producing the AGO postcards of

56 Smith, Michael J. \& W. O. (Bill) Buchanan, Warwick Bros. \& Rutter Postcard Gems 1903 - 1912, (2011): 12 .

57 Smith, Michael J., The W. G. MacFarlane Picture Postcard Handbook 1902 - 1910, (2010): 9. 
Toronto had relied on the superior printing facilities offered by German companies. Due to shortages of paper and ink, and the redirecting of supplies to the war effort, the production of postcards, a novelty item for many publishers, was unsustainable. A limited number of publishers including Valentine \& Sons continued to produce postcards after the war.

In all but two cases the AGO postcards show a printed title on the recto of the postcard. The names of significant buildings such as the Royal Ontario Museum (constructed in 1910-11), the Carnegie Library (constructed in 1906-09) and Government House (constructed in 1911-15) are clearly prominent in the title. Other titles, for example, Technical School and College Street, Toronto, identify a structure and the street on which the building is located and includes a streetcar and a horse drawn carriage, subjects that are common place for a city undergoing modernization. Some titles identify a street such as St. George Street to show quiet neighbourhoods or bustling thoroughfares. Recreational events such as picnicking on Toronto Islands or attending the Canadian National Exhibition are also common scenes. Additionally cards such as, Lagoon at Island Park, Toronto and Humber River View reproduce bucolic scenes. Thus the AGO collection of postcards depicts a cross section of views of buildings, streets, events and landscapes in Toronto. Taken together we can consider postcards as a means of circulating photographs of significant changes taking place in the City of Toronto thus educating the citizenry and encouraging newcomers to visit.

The AGO postcards manifest specific uses and reasons for their production. Postcards published by the Dept. of Publicity, Canadian National Exhibition, the Advertising Dept. Walker House, the Walter M. Lowney Co. of Canada Ltd. and the Kiwanis Club of West Toronto are specifically produced for promotional purposes. The cards published by the CNE and the Kiwanis Club also contain biographical information related to attendance. The 
card by Walker House announces a specific event related to an exhibition of airplanes in Toronto commencing after World War I and promotes the availability of rooms at the hotel. A postcard depicting Fort York and published by the Toronto Convention \& Tourist Association highlights the history of a notable landmark of the City of Toronto to citizens and visitors to Toronto.

The postcard titled Toronto, St. George Street (see page 146 of the catalogue) and published by W. J. Cage Co. of Toronto displays the imprint of the Galbraith Photo Co. and offers an opportunity to consider the exchange of photographs between photographers and the publishers of postcards. The Galbraith Photo Co. operated by Alexander W. Galbraith was established in 1901 and continued operation until 1922. The Canadian View Card Company published a postcard titled St. George Street, Toronto (see page 147 of the catalogue) identical to the postcard published by the W. J. Cage Co. Thus two postcards bearing the same image by the same photographer but reproduced by two different publishers suggests that the photographer may have made his photographs available to more than one publisher or that publishers may have sold photographs to other publishers.

While rare that the photographer of the image on the postcard is identified, the AGO collection contains four postcards reproducing photographs by Galbraith Photo Co. Two postcards are published by The Canadian View Card Co., one by the W. J. Gage Co. Ltd. and the last by an unknown publisher. The postcard by the unknown publisher depicts the Armouries (see page 36 of the catalogue) once located just north of the intersection of Queen Street West and University Avenue. Online research has revealed that both Warwick Bro's \& Rutter Co. and Arthur Strauss Inc. reproduced the same image. From this we can infer that the Galbraith Photo Co. sold the same photographs to multiple publishers. Research has shown that Galbraith also dealt with the Canadian National Exhibition in 
Toronto ${ }^{58}$. At this time it is not possible to confirm if he was also responsible for the photographs used in the production of postcards depicting scenes of the CNE.

As reported above, publishers often manipulated the photographs they published. The AGO collection contains an example of one form of this manipulation. Two postcards titled, A Glimpse of the Manufacturers' Building, Toronto Exhibition by night (fig. 1) and $A$ Glimpse of the Manufacturers' Building, Toronto Exhibition, Canada (fig. 2) are of the same image. The latter depicts a daylight scene while the former shows a darkened sky with clouds and a 'halo' of light around each of the streetlights to give the impression of a nighttime view.

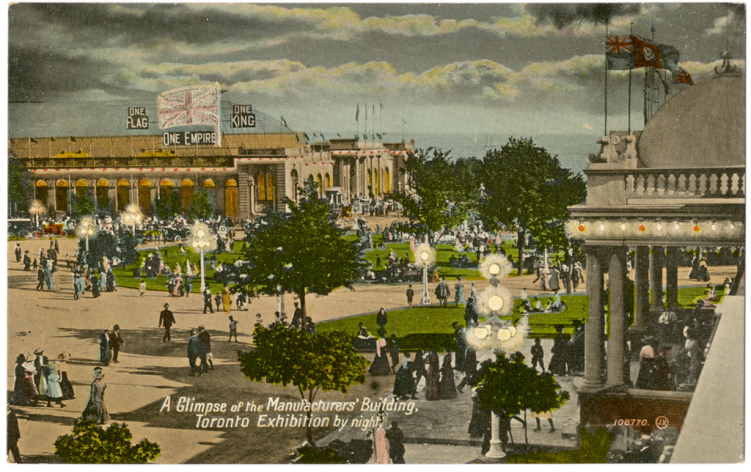

figure 1

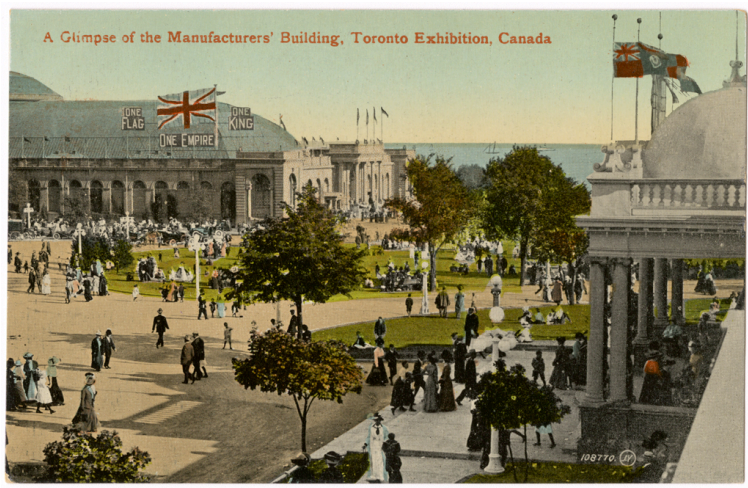

figure 2

58 Canadian National Exhibition Archives, http://www.cnearchives.com/ dbtwwpd/exec/dbtwpub.dll. 
A comparison of the AGO postcard collection with the TRL's shows more dramatic changes. The Valentine-Black Co. Ltd. produced two postcards with the same image and title, "Sunnyside" Toronto, Canada. The postcard located at the TRL depicts what appears to be an aerial view of Sunnyside Park (fig. 3); whereas the AGO postcard has been altered by the elimination of poles, the shape of the automobiles and the use of saturated colour (fig. 4). The image on the AGO postcard titled, King Street, Toronto, Canada (fig. 5) and published by the W. G. MacFarlane Co. Ltd. was also reproduced by Raphael Tuck \& Sons and titled Toronto, King Street (fig. 6). The AGO card depicts street level view with subdued colour while the 'Tuck' postcard exhibits brighter colours and the marked inclusion of a figure with a cane crossing the street followed by a dog absent from the W. G. MacFarlane Co., Ltd. postcard.

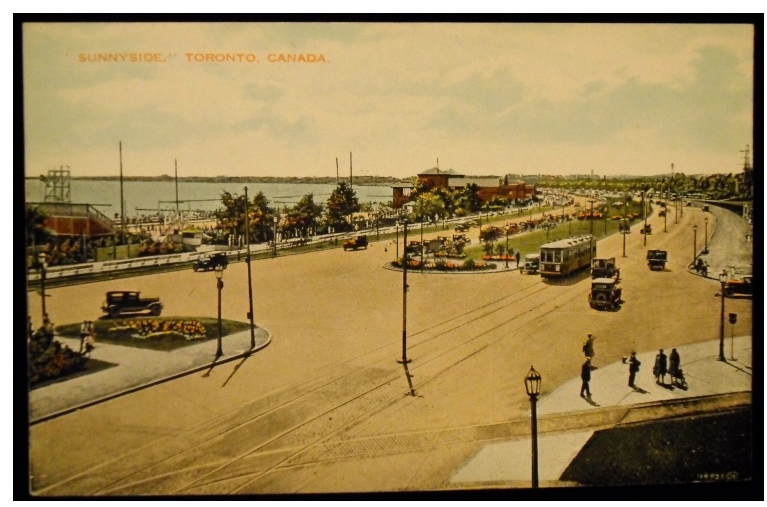

figure 3

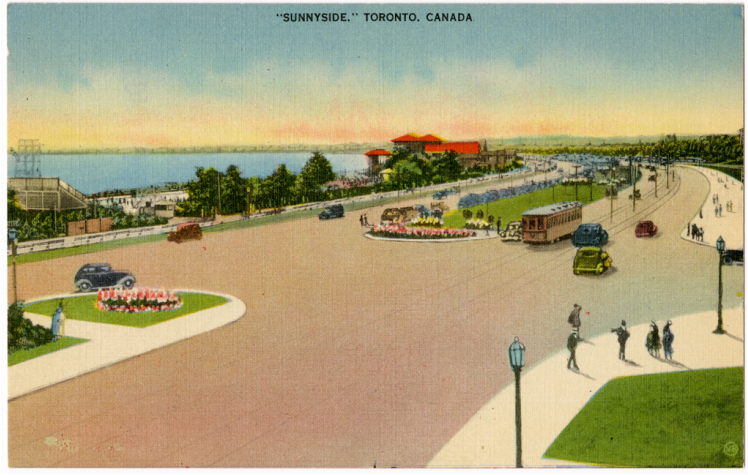

figure 4 
The comparison of these two postcards poses questions related to the processes used and dates of their production as well as their intended audiences. We know that the W. G. MacFarlane Co., Ltd. located in Toronto, published postcards between 1902 and 1910 while Raphael Tuck \& Sons located in London, England published greeting cards including postcards between 1866 and 1960. It appears that the image for this postcard migrated from Toronto to London possibly when W. G. MacFarlane Co., Ltd. ceased producing postcards and possibly sold the image to Raphael Tuck \& Sons. We might also conclude that "Tuck" had greater resources to take advantage of the image for retail.

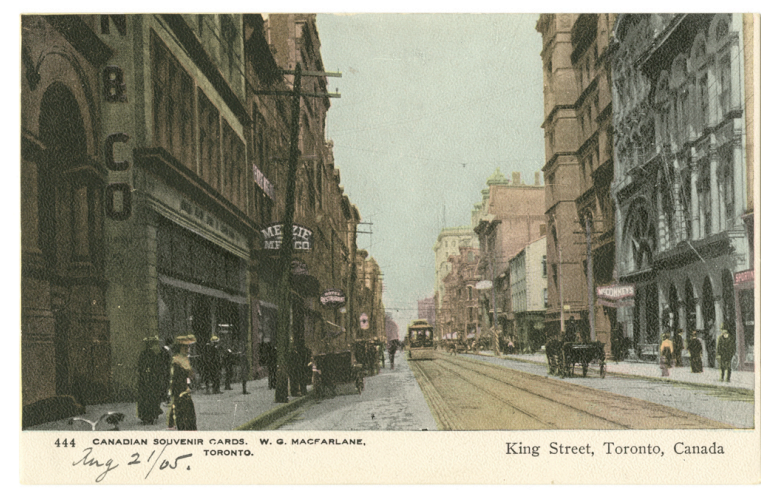

figure 5

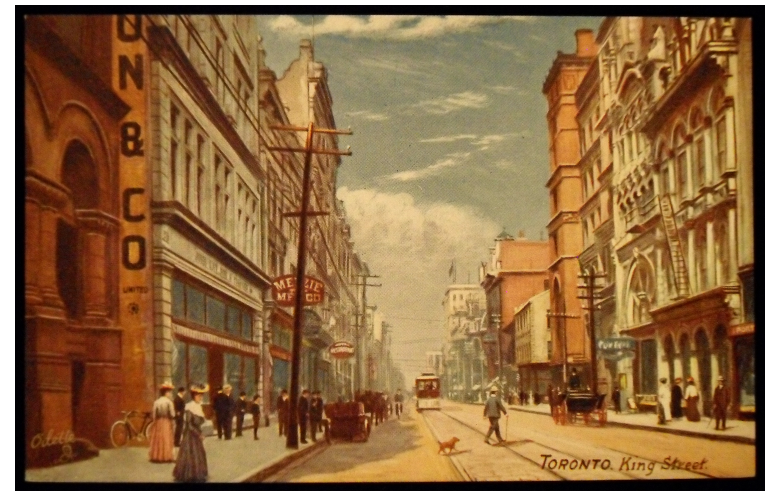

figure 6 
While different publishers published the same photograph, and while they felt free to add colour, figures or eliminate parts of the image they did not want, they also produced different-looking postcards by printing the photograph with different processes. Valentine \& Sons Co. Ltd. published a colour postcard titled, York Pioneers House, Exhibition Grounds at Sunset, Toronto, Canada (fig 7) employing the letterpress halftone process. They published the same image using the collotype process to produce a monochromatic image with a different design. (fig. 8). The latter was produced prior to 1908 and the former after that year when the Valentine \& Sons Co. Ltd. had adopted the motto 'famous throughout the world'.

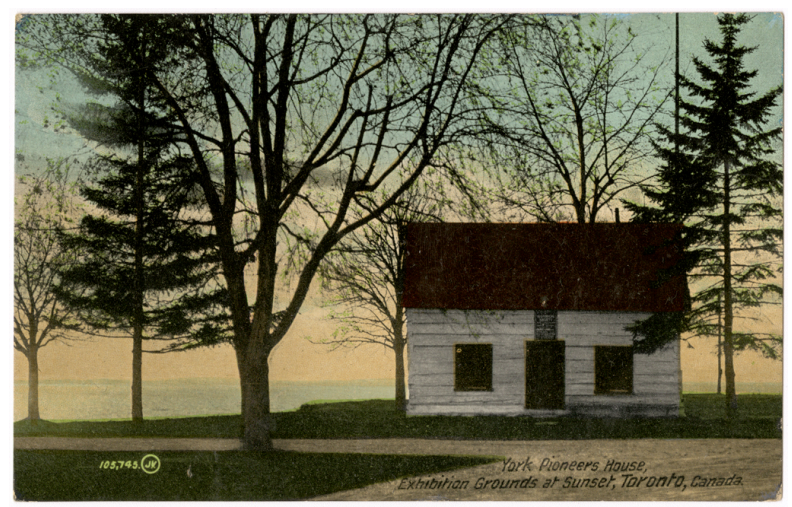

figure 7

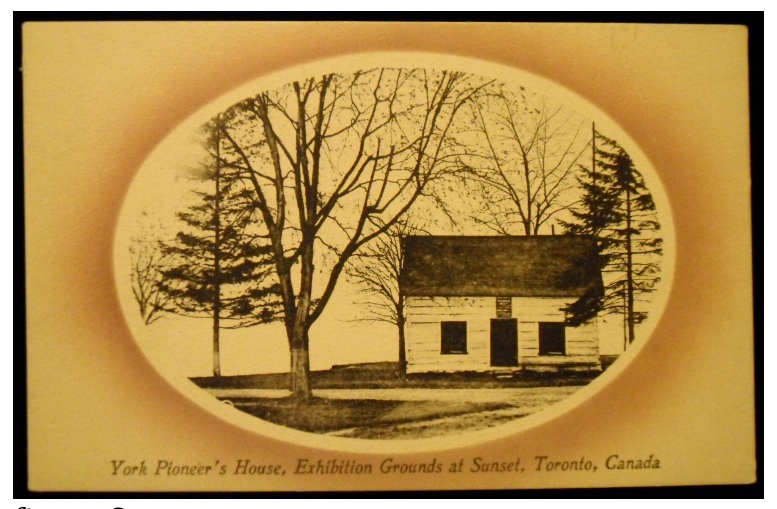

figure 8 
At the beginning of the "Golden Age of Postcards" (1900 to 1914) the quality of postcards was paramount. Postcards produced using the collotype and rotogravure processes were popular with the public, postcard clubs and collectors fueling the demand for further production. However, by 1912, increased production costs and the availability of production supplies diminished the quality of postcards and signaled the end of the Golden Age. The white borders of the White Border era (1915-1930) marked a means for publishers to save on the cost of ink and paper. As well as production and supply difficulties a lack of new subject views, the inactivity of postcard clubs and collectors and the dwindling of profits caused by a glut of postcard also contributed to the decline of the Golden Age. But as postcards were responsible for creating "a historical visual record that encompassed the world"59 their diminishing popularity is equally owed to the publication of photography in popular magazines and newspapers. ${ }^{60}$ Photographs in these mass media finally displaced the postcard as means for the distribution of photographic imagery.

59 Woody, op cit., 15.

60 Ibid, 42-43. 


\section{Conclusion}

The full cataloguing of the Art Gallery of Ontario's collection of one hundred and sixteen postcards offers the opportunity to consider both the histories of postcards and the City of Toronto in the opening decades of the twentieth century. I have argued that postcards offer a visual documentation for the study of changes in the urban environment. Postcards can also be shown to be a successful means for the dissemination of photographic imagery prior to the introduction of photographs in the popular media of the day. While we can observe the manipulation of the photographic image the significance of the content of the image of postcards should not be dismissed. The depiction of major institutions including the Royal Ontario Museum and Toronto's Main Reference Library constructed from 1906 to 1911 reveals a city in the throes of modernization. The scenes of the Toronto Industrial Exhibition and the Canadian National Exhibition show Toronto as a burgeoning centre for commerce and tourism. Scenes of the public picnicking on the Toronto Islands and visiting Hanlan's Point and Sunnyside Amusement Parks depict the extent of Toronto's recreational facilities.

Additionally the AGO postcards offer an occasion to consider the economic relationships between photographers and publishers, and publishers and publishers of postcards. While the collection has revealed Alexander W. Galbraith as a photographer producing images for postcards, it is possible with further research to identify other commercial photographers working in Toronto during the period from 1900 to 1930 . For example, Henry Pellat the original owner of Casa Loma often engaged the services of 
William James, a successful Toronto commercial photographer from 1909 to the $1930 \mathrm{~s} .{ }^{61}$ It may be possible to ascribe images on the postcards of Casa Loma to him. It is hoped that further research will expand upon the information included in the cataloguing of the AGO postcards to supplement existing information about commercial photography in the City of Toronto at the beginning of the twentieth century.

Finally the humble photographic postcard can offer information gleaned from its content and production to further our understanding of the modernization of the City of Toronto and commercial photography adding to an as yet unwritten history of photography.

61 Patrick Cummins, archivist, City of Toronto Archives, interview by author, Toronto, Ontario, April $17,2013$. 


\section{Catalogue of AGO Postcards}

\section{Introduction}

The fourteen TMS fields for the cataloguing of the AGO collection of postcards are defined in the order employed as they appear in the following catalogue.

\section{AGO Accession Number}

This field provides the number assigned to each object in the AGO's permanent collection. The first four numbers indicate the year followed by a forward slash and consecutive numbers of items accessioned that year.

\section{Classification}

The field provides the category of the object according to existing criteria.

\section{Constituents}

This field provides the names of photographers and publishers responsible for production of the postcard

\section{3a. Publisher}

This field provides the name of the publisher imprinted on the verso of the postcard

\section{3.b Photographer}

This field provides the name of the photographer responsible for the photographic image printed on the postcard 


\section{Constituents Note}

This field provides biographical information about the publisher of the postcard and the photographer responsible for the image printed on the postcard.

\section{Title}

This field provides the title of the postcard.

\section{5a. Title Note}

This field provides the title type, printed or descriptive for the postcard.

\section{Date(s) of Object}

This field provides the date(s) for the production of the postcard.

\section{6a. Date Notes}

This field provides the postmarked date stamped on the recto and verso of postcard and provides a span of dates associated with the history of the publisher in relation to the production of the postcard.

\section{Object Name}

This field provides the type of object.

\section{Medium}

This field provides the photomechanical process by which the postcard was produced. 


\section{Dimensions}

This field provides information concerned with the physical dimensions of the postcard, height proceeding width.

\section{9a. Image}

This field provides the dimensions of the image (without borders).

\section{9b. Sheet}

This field provides the dimensions of the support for the image.

\section{Geography}

This field provides the locations of the production of the postcard and the location depicted in the image of the postcard.

\section{0a. Place Created}

This field provides the location for the production of the postcard.

\section{0.b Place Depicted}

This field provides the location depicted in the image of the postcard.

\section{1. $\operatorname{Mark}(\mathbf{s})$}

This field provides all words or numbers written on the recto and verso of the postcard.

\section{Inscription}

This field documents the imprints by the publisher on the recto and verso of the postcard. 


\section{(Key of Inscription location)}

t.l. - top left

t.c. - top centre

t.r. - top right

c.l. - centre left

c. - centre

c.r. - centre right

l.l. - lower left

l.c. - lower centre

l.r. - lower right

\section{Notes}

This field provides biographical information about the subject reproduced on the recto of the postcard

\section{Alternate Number}

This field provides the number assigned to the postcard prior to accession into the AGO's permanent collection. 


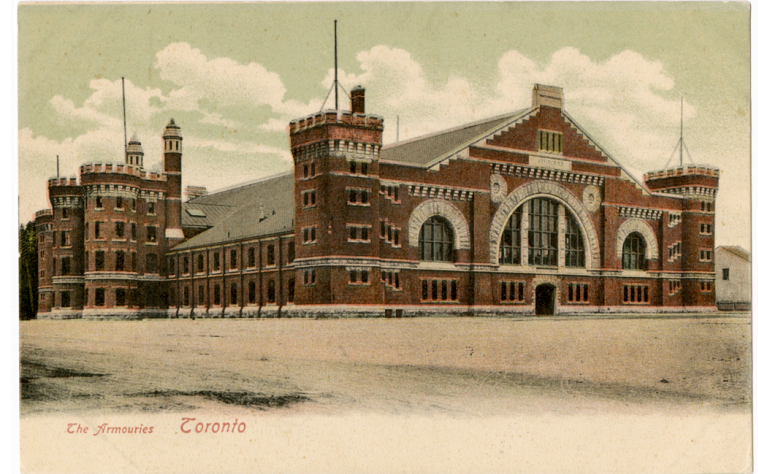

Recto

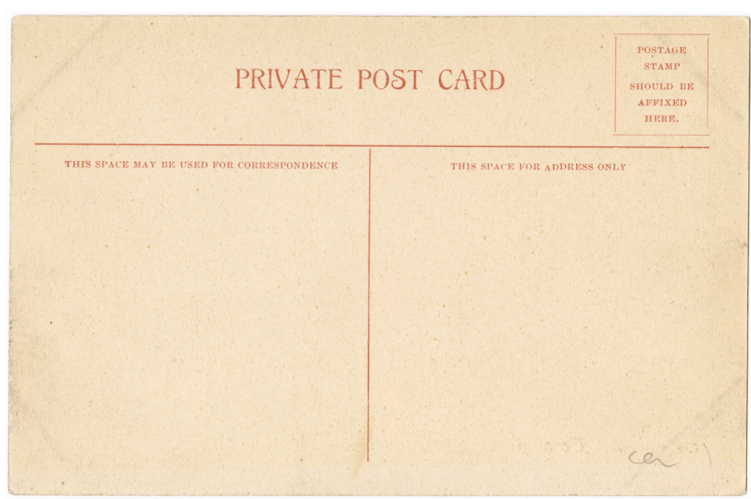

Verso

AGO Accession Number - 2011/140

Classification: Photography Collection

Constituent:

Publisher: Unknown

Photographer: Alexander W. Galbraith Creator Note: Alexander W. Galbraith (1867-1950) was a commercial photographer in Toronto from 1899 to 1924.

Title: The Armouries, Toronto

Title Note: Printed

Date(s) of Object: ca1910

Date Notes:

Object Name: Postcard

Medium: Rotogravure

Dimensions:

Image: $7.8 \times 13.8 \mathrm{~cm}, 3.07 \times 5.43$ in

Sheet: $7.8 \times 13.8 \mathrm{~cm}$; $3.07 \times 5.43 \mathrm{in}$

Geography:

Place Created: Unknown

Place Depicted: Queen Street West at University Avenue (NE), Toronto, Ontario

Mark(s): recto: titled; verso: post

template

Inscriptions: None

Notes: The Armouries designed in the Romanesque style by architect Thomas Fuller (1823-1898) and constructed between 1891 and 1893. The building was demolished in 1963.

Alternate Number: AG0.98591 


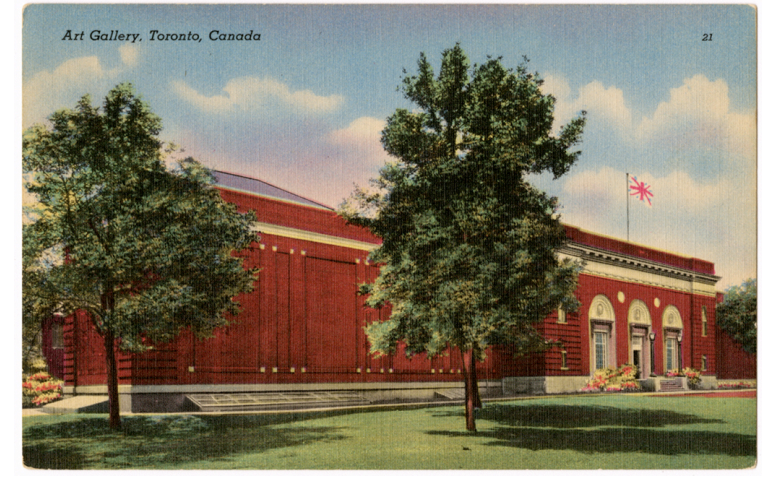

Recto

AG0 Accession Number: 2011/155

Classification: Photography Collection

Constituents:

Publisher: Royal Specialty Sales,

Toronto

Photographer: Unknown

Constituents Note: The Royal Specialty

Sales Co. was founded in 1937 and

presently maintains operations in East

York, Toronto.

Title: Art Gallery, Toronto, Canada

Title Note: Printed

Date(s) of Object: [after 1937]

Date Notes: Royalty Specialty Sales

founded in 1937

Object Name: Postcard

Medium: Offset lithograph

Dimensions:

Image: $8.8 \times 13.8 \mathrm{~cm}, 3.46 \times 5.43 \mathrm{in}$

Sheet: $8.8 \times 13.8 \mathrm{~cm}, 3.46 \times 5.43$ in

Geography:

Place Created: Boston, Massachusetts,

U.S.A.

Place Depicted: south west corner of

Dundas Street at McCaul Street (SW),

Toronto, Ontario

Mark(s): recto: titled; verso: post template; publisher trademark, location of printing; [no.] K1338

Inscriptions: None

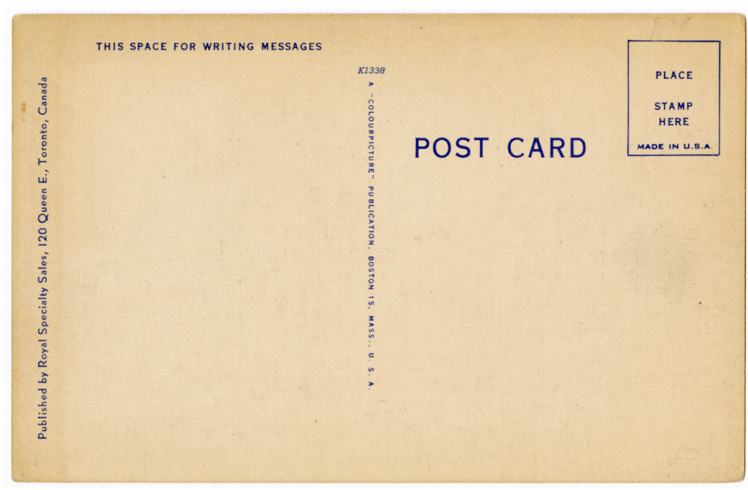

Verso

Notes: Designed by architects Frank Darling (1850-1923) and John Andrew Pearce (1867-1940) in the Beaux Arts Style. The Art Gallery of Toronto was constructed in 1916-18. Walker Court with East and West Wings were constructed in 1924-25 and 1935.

Alternate Number: AG0.98620 


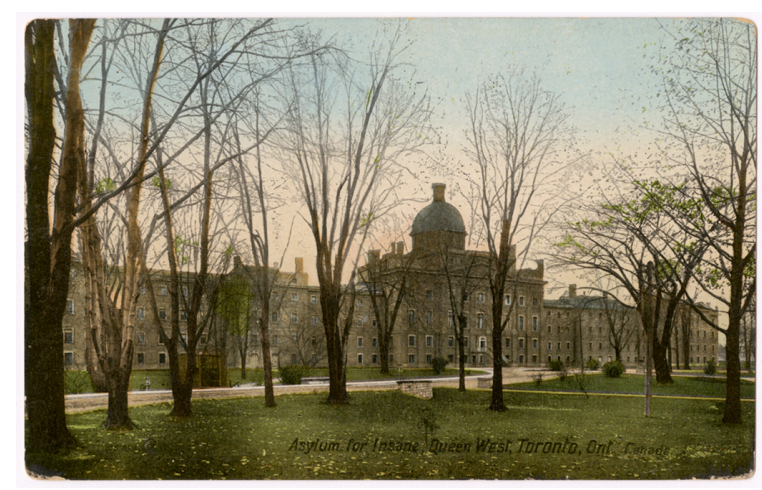

Recto

AGO Accession Number: 2011/156

Classification: Photography Collection

\section{Constituents:}

Publisher: The Valentine \& Sons Co. Ltd. Montreal and Toronto

Photographer: Unknown

Constituents Note: The Valentine \& Sons

Publishing Co. Ltd. was founded in

Montreal and Toronto in 1903 and 1906

respectively. Operations were terminated in 1923.

Title: Asylum for Insane, Queen West, Toronto, Ont.

Title Note: Printed

Date(s) of Object: [between 1908 and 1912]

Date Notes: The card is postmark on, verso July 26, 1912 and was printed after Valentine \& Sons began to use the 'FAMOUS THROUGHOUT THE WORLD' trademark in 1908.

Object Name: Postcard

Medium: Letterpress halftone

Dimensions:

Image: $8.8 \times 13.9 \mathrm{~cm}, 3.46 \times 5.43$ in

Sheet: $8.8 \times 13.9 \mathrm{~cm}, 3.46 \times 5.43$ in

Geography:

Place Created: Great Britain

Place Depicted: 999 Queen Street West located opposite Ossington Avenue, Toronto, Ontario

Mark(s): recto: titled; verso: publisher imprint, trademark, post template

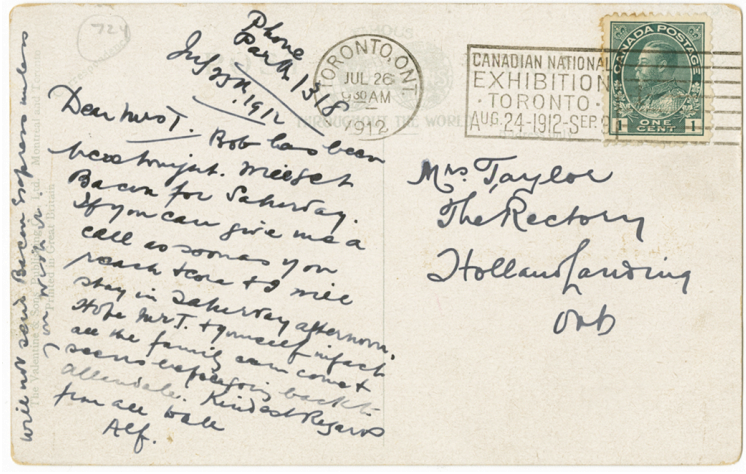

Verso

Inscriptions: verso: ink: Phone Perth (?) 1318 July 25th 1912 [underlined] Dear Mrs T. Bob has been [unreadable] Will get Bacon for Saturday. If you can give us a call as soon as you reach tcora (?) \& I will stay in Saturday afternoon. Hope Mr. T \& yourself infact all the family can come \& [unreadable] back to Allendale. Kindest Regards from all [unreadable] Alf. Will not send Bacon express (?) unless you wish it. Mrs. Taylor The Rectory Holland Landing Ontario

Notes: Designed by architect John George Howard (1803-1890) construction for the Asylum commenced in 1845 and was completed in 1858. The asylum was demolished in 1976.

Alternate Number: AG0.98621 


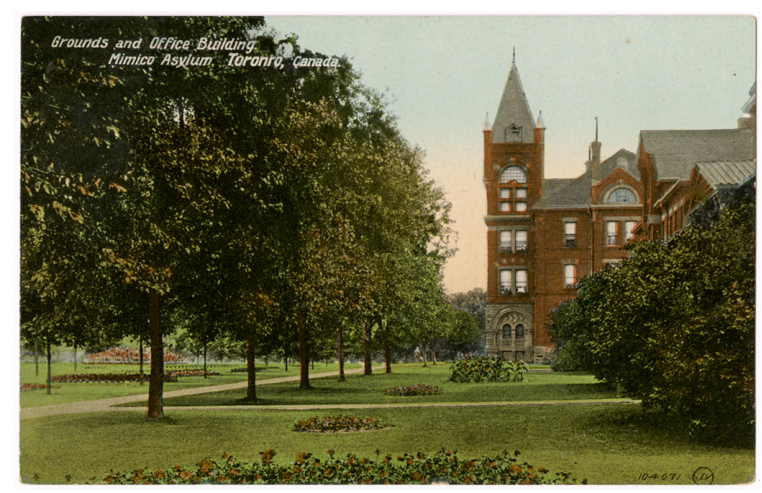

Recto

AG0 Accession Number: 2011/157

Classification: Photography Collection

Constituents:

Publisher: The Valentine \& Sons Co.

Ltd. Toronto and Montreal

Photographer: Unknown

Constituents Notes: The Valentine \&

Sons Publishing Co. Ltd. was founded in

Montreal and Toronto in 1903 and 1906

respectively. Operations were terminated in 1923.

Title: Grounds and Office Building Mimico Asylum, Toronto, Canada

Title Note: Printed

Date(s) of Object: [between 1908 and 1911]

Date Notes: The card is postmarked March 7, 1911 and was printed after Valentine \& Sons began to use the 'FAMOUS THROUGHOUT THE WORLD' trademark in 1908.

Object Name: Postcard

Medium: Letterpress halftone

Dimensions:

Image: $8.6 \times 13.5 \mathrm{~cm}, 3.39 \times 5.31$ in

Sheet: $8.6 \times 13.5 \mathrm{~cm}, 3.39 \times 5.31 \mathrm{in}$

Geography:

Place Created: Great Britain

Place Depicted: 3131 Lakeshore

Boulevard West, Toronto, Ontario

Mark(s): recto: titled, [no.] 104,071 JV

[circled] verso: publisher imprint, trademark, post template

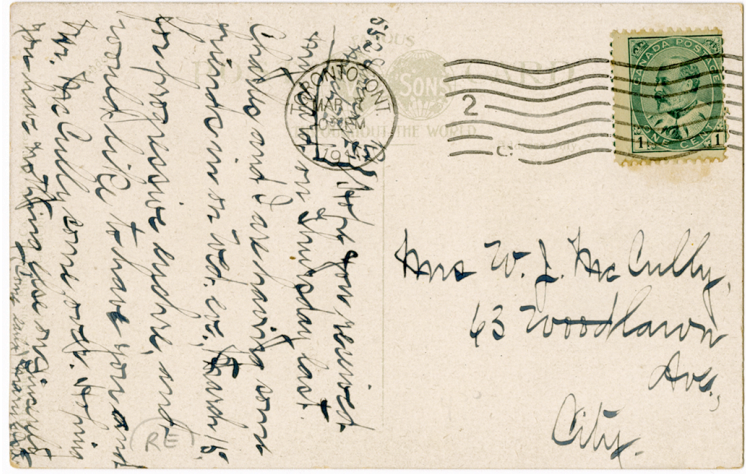

Verso

Inscriptions: verso: ink: writing Hope you received my car on Thursday last Charles and I are having some friend in on Wed eve. March 15 for progressive euchre and would like to have you and $\mathrm{Mr}$. McCully come over. Hoping you have nothing else on. Come early Mary Mrs W. J. McCully 63 Woodlawn Ave City Notes: Designed by Kivas Tully (18201905), the Chief Provincial Architect, the Asylum for the Insane was constructed in a combination of Romanesque and Gothic Revival styles between 1888 and 1894 . The asylum opened in 1889 and closed 1979. Originally named the Mimico Branch Asylum during its years of operation the asylum was known as the Mimico Insane Asylum (1894), Ontario Hospital, Mimico (1920), Ontario Hospital, New Toronto (1934) and Lakeshore Psychiatric Hospital (1964). Alternate Number: AG0.98622 


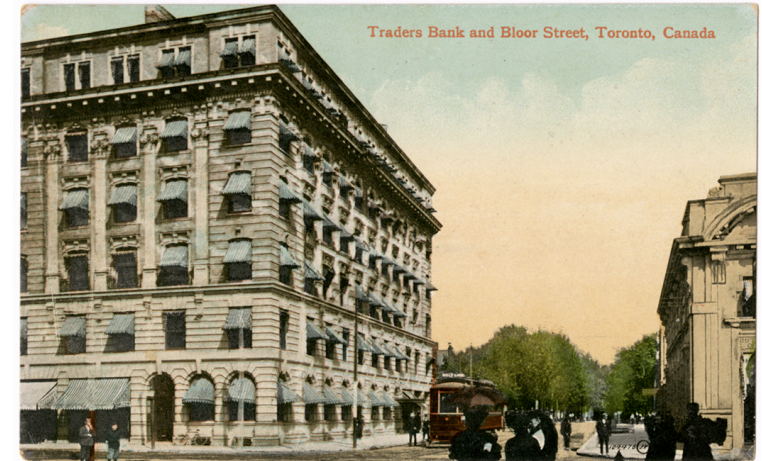

Recto

AGO Accession Number: 2011/158

Classification: Photography Collection Constituents:

Publisher: The Valentine \& Sons Co. Ltd. Montreal and Toronto

Photographer: Unknown

Constituents Notes: The Valentine \& Sons Publishing Co. Ltd. was founded in Montreal and Toronto in 1903 and 1906 respectively. Operations were terminated in 1923.

Title: Traders Bank and Bloor Street, Toronto, Canada

Title Note: Printed Date(s) of Object: [between 1908 and 1910]

Date Notes: The card is postmarked May 10, 1910 and was printed after Valentine \& Sons began to use the 'FAMOUS THROUGHOUT THE WORLD' trademark in 1908.

Object Name: Postcard

Medium: Letterpress halftone

Dimensions:

Image: $8.6 \times 13.8 \mathrm{~cm} ; 3.39 \times 5.31 \mathrm{in}$

Sheet: $8.6 \times 13.8 \mathrm{~cm} ; 3.39 \times 5.31$ in

\section{Geography:}

Place Created: Great Britain

Place Depicted: 61-7 Yonge Street at

Colborne (NE)

Mark(s): recto: titled, [no.] 104,476 JV

[circled]; verso: publisher imprint, trademark, post template

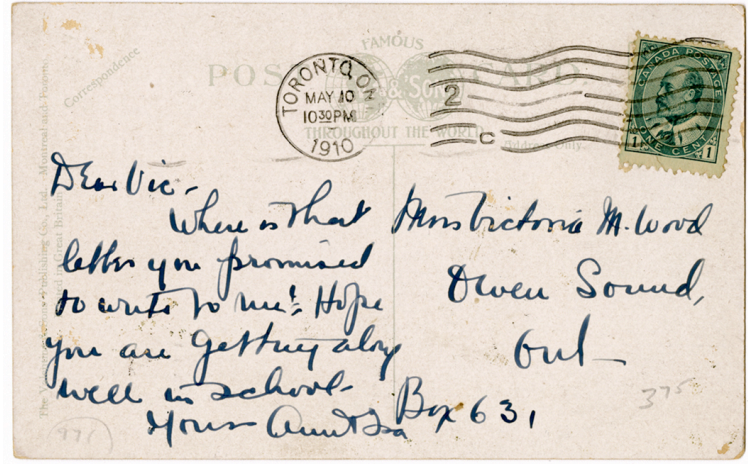

Verso

Inscriptions: verso: ink: writing Dear Vic Where is that letter you promised to write to me. Hope you are getting along well in school. Your Aunt Isa (?) Miss Victoria M. Wood Owen Sound, Ont.; in graphite: [no] 375 l.r.

Notes: Designed by Francis Spence Baker (1867-1926) the Trader's Bank was constructed in $1906-07$ and demolished in 1965.

Alternate Number: AG0.98623 


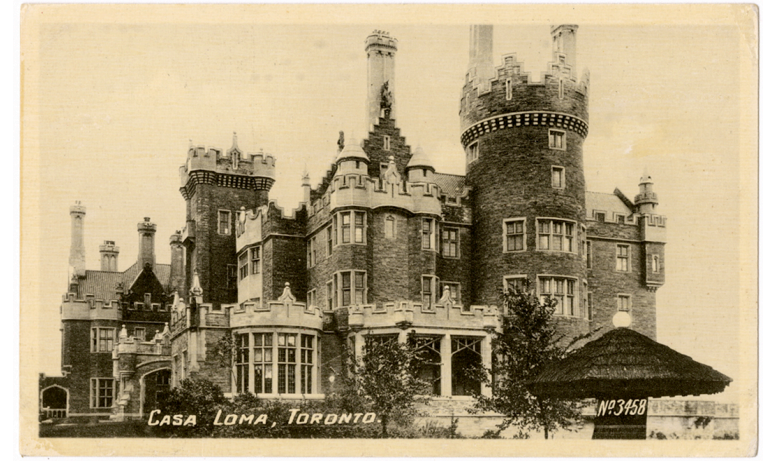

Recto

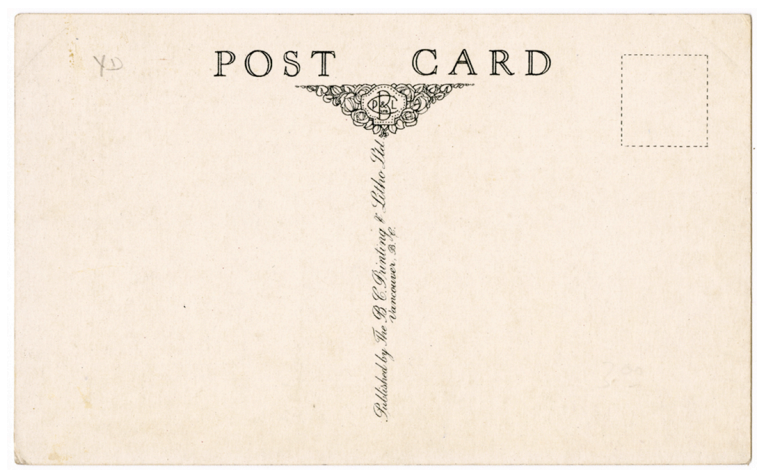

Verso

AGO Accession Number: 2011/159

Classification: Photography Collection

Constituents:

Publisher: The B. C. Printing \& Litho

Ltd. Vancouver, B. C.

Photographer: Unknown

Constituents Note: The B. C. Printing \&

Litho Ltd. was established in Vancouver,

B. C. between 1928 and 1930

Title: Casa Loma, Toronto

Title Note: Printed

Date(s) of Object: [between 1928 and

1930]

Object Name: Postcard

Medium: Collotype

Dimensions:

Image: $7.7 \times 13.2 \mathrm{~cm}, 3.03 \times 5.43$ in

Sheet: $8.5 \times 13.9 \mathrm{~cm}, 3.35 \times 5.20 \mathrm{in}$

Geography:

Place Created: Vancouver, B. C.

Place Depicted: 1 Austin Terrace, at

Walmer Road (SE), Toronto, Ontario

Mark(s): Recto: titled, [no.] 3458; Verso:

publisher imprint, trademark, post

template

Inscriptions: None

Notes: Designed by architect Edward James Lennox (1855-1933) Casa Loma was constructed in the Gothic Revival style from 1909 to 1911 for financier Henry M. Pellat.

Alternate Number: AGO.98624 


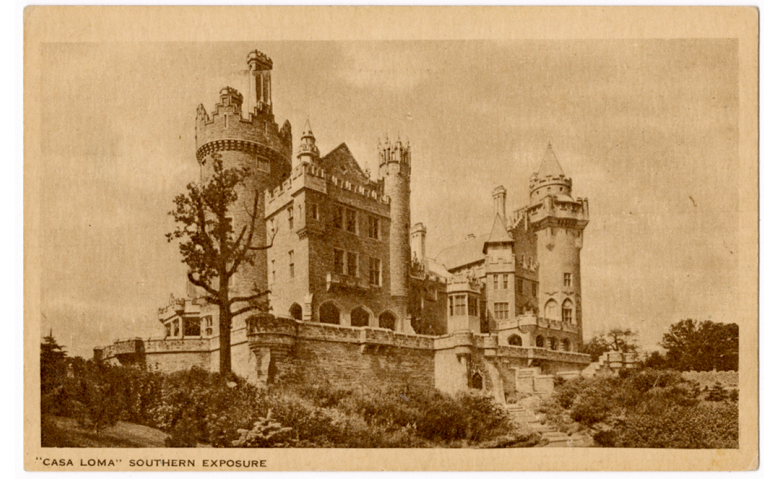

Recto

AGO Accession Number: 2011/160

Classification: Photography Collection

Constituents:

Publisher: Kiwanis Club of West

Toronto, Inc.

Photographer: Unknown

Constituents Note: The Kiwanis Club of

West Toronto managed Casa Loma

from 1937 to 2011 when the City of

Toronto resumed management.

Title: "Casa Loma" Southern Exposure

Title Note: Printed

Date(s) of Object: [after 1937]

Date Notes: The Kiwanis Club of West

Toronto commenced operations of Casa

Loma in 1937. White borders were first introduced in 1915.

Object Name: Postcard

Medium: Photogravure

Dimensions:

Image: $7.7 \times 13.2 \mathrm{~cm}, 3.03 \times 5.20 \mathrm{in}$

Sheet: $8.8 \times 14.0 \mathrm{~cm}, 3.46 \times 5.51 \mathrm{in}$

\section{Geography:}

Place Created: unknown

Place Depicted: 1 Austin Terrace, at

Walmer Road (SE), Toronto, Ontario

Mark(s): recto: titled; verso: post template, site description imprint, BEAUTIFUL CASA LOMA Davenport Rd. at Spadina Ave. The Million Dollar Castle of America on the Hill, Toronto; a mecca for tourists who throng there daily.

Magnificent view of Toronto. One hour's

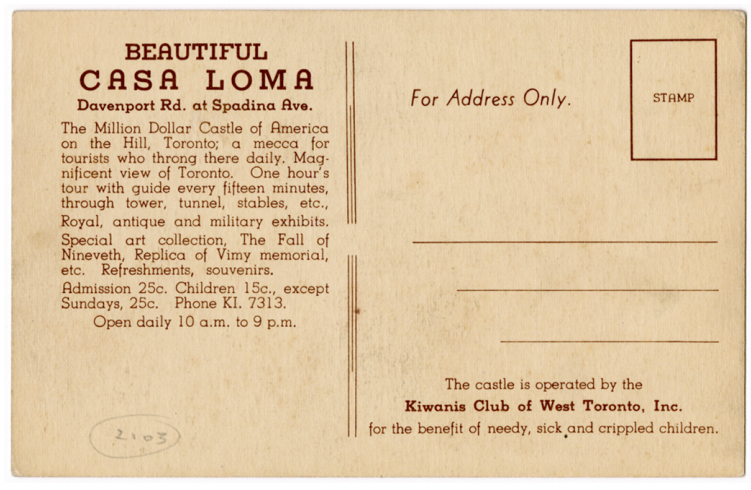

Verso

tour with guide every fifteen minutes, through tower, tunnel, stables, etc., Royal, antique and military exhibits. Special art collection, The Fall of Nineveth, Replica of Vimy memorial etc. Refreshments, souvenirs. Admission 25c. Children 15c., except Sundays, 25c. Phone KI. 7313. Open daily 10 a.m. to 9 p.m. The castle is operated by the Kiwanis Club of West Toronto, Inc. for the benefit of needy, sick and crippled children.

Inscriptions: verso: in graphite: [no.] 2103 [circled] l.l.

Notes: Designed by architect Edward James Lennox (1855-1933) Casa Loma was constructed in the Gothic Revival style from 1909 to 1911 for financier Henry M. Pellat.

Alternate Number: AG0.98625 


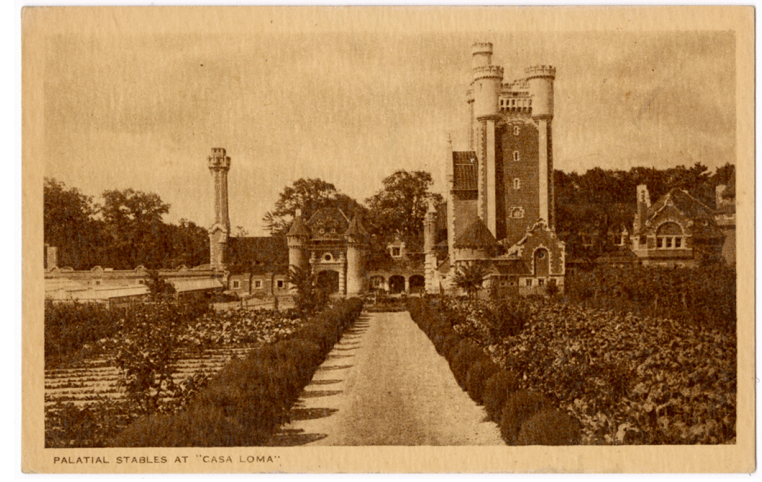

Recto

AGO Accession Number - 2011/161

Classification: Photography Collection

Constituents:

Publisher: Kiwanis Club of West

Toronto, Inc.

Photographer: Unknown

Constituents Note: The Kiwanis Club of

West Toronto managed Casa Loma

from 1937 to 2011 when the City of

Toronto resumed management.

Title: Palatial Stables at "Casa Loma"

Title Note: Printed

Date(s) of Object: [after 1937]

Date Notes: The Kiwanis Club of West

Toronto commenced operations of Casa

Loma in 1937. White borders were first introduced in 1915.

Object Name: Postcard

Medium: Photogravure

Dimensions:

Image: $7.7 \times 13.2 \mathrm{~cm}, 3.03 \times 5.20 \mathrm{in}$

Sheet: $8.8 \times 14.0 \mathrm{~cm}, 3.46 \times 5.51 \mathrm{in}$

\section{Geography:}

Place Created: unknown

Place Depicted: 1 Austin Terrace, at

Walmer Road (SE), Toronto, Ontario

Mark(s): recto: titled; verso: post template, site description imprint, BEAUTIFUL CASA LOMA Davenport Rd. at Spadina Ave. The Million Dollar Castle of America on the Hill, Toronto; a mecca for tourists who throng there daily.

Magnificent view of Toronto. One hour's

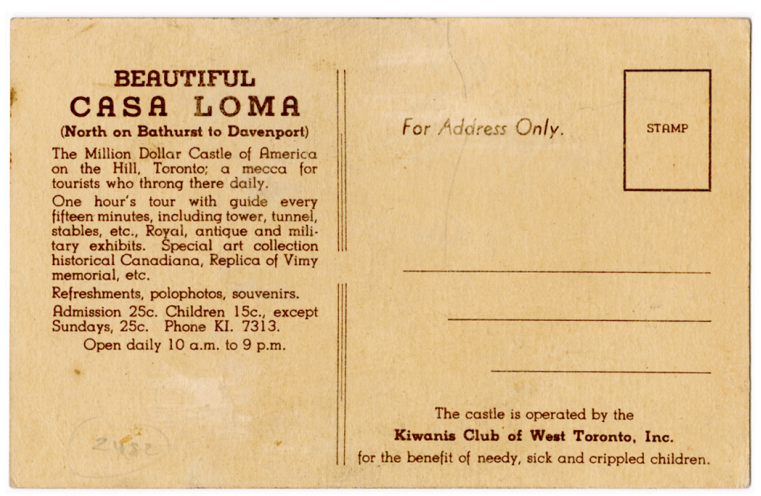

Verso

tour with guide every fifteen minutes, through tower, tunnel, stables, etc., Royal, antique and military exhibits. Special art collection, The Fall of Nineveth, Replica of Vimy memorial etc. Refreshments, souvenirs. Admission 25c. Children 15c., except Sundays, 25c. Phone KI. 7313. Open daily 10 a.m. to 9 p.m. The castle is operated by the Kiwanis Club of West Toronto, Inc. for the benefit of needy, sick and crippled children.

Inscriptions: verso: in graphite: [no.] 2432 [circled] 1.l.

Notes: Designed by architect Edward James Lennox (1855-1933) Casa Loma was constructed in the Gothic Revival style from 1909 to 1911 for financier Henry M. Pellat..

Alternate Number: AG0.98624 


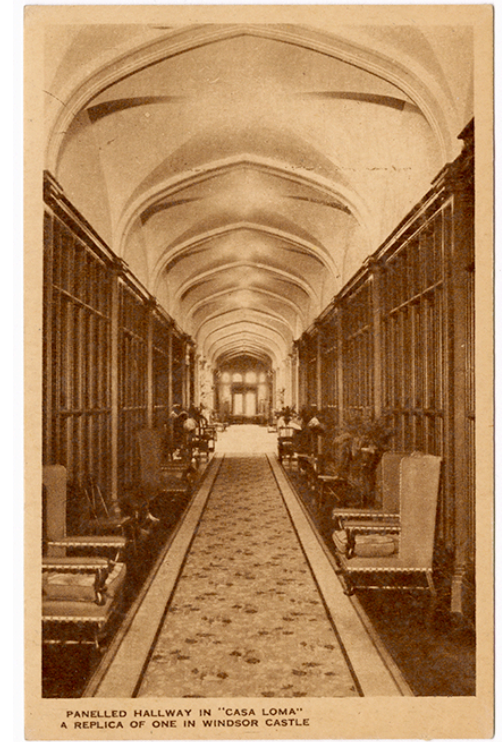

Recto

AGO Accession Number: 2011/162

Classification: Photography Collection Constituents:

Publisher: Kiwanis Club of West

Toronto, Inc.

Photographer: Unknown

Creator Note: The Kiwanis Club of West

Toronto managed Casa Loma from 1937

to 2011 when the City of Toronto

resumed management.

Title: Panelled Hallway in "Casa Loma," a Replica of one in Windsor Castle

Title Note: Printed

Date(s) of Object: [after 1937]

Date Notes: The Kiwanis Club of West

Toronto commenced operations of Casa Loma in 1937. White borders were first introduced in 1915.

Object Name: Postcard

Medium: Photogravure

Dimensions:

Image: $12.8 \times 8.2 \mathrm{~cm}, 5.04 \times 3.23$ in

Sheet: $14.0 \times 8.9 \mathrm{~cm}, 5.51 \times 3.50 \mathrm{in}$

\section{Geography:}

Place Created: unknown

Place Depicted: 1 Austin Terrace, at

Walmer Road (SE), Toronto, Ontario

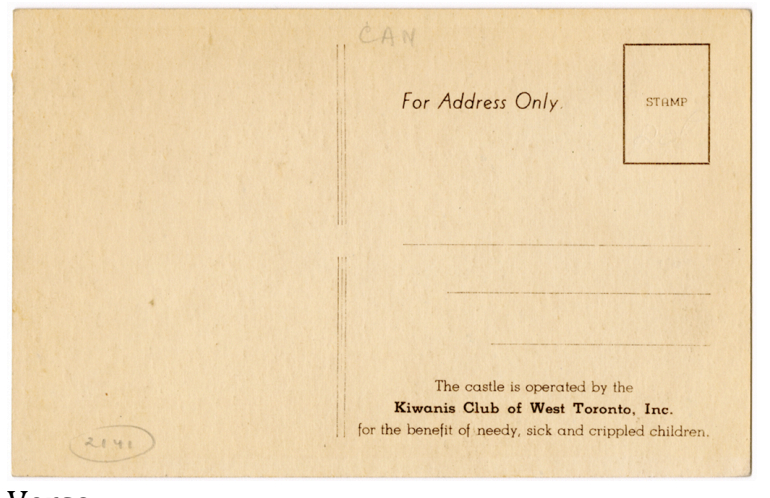

Verso

Mark(s): recto: titled; verso: post template, publisher imprint, The castle Is operated by the Kiwanis Club of West Toronto, Inc. for the benefit of needy, sick and crippled children.

Inscriptions: verso: in graphite: [no.] 2141 [circled] l.l.

Notes: Designed by architect Edward James Lennox (1855-1933) Casa Loma was constructed in the Gothic Revival style from 1909 to 1911 for financier Henry M. Pellat.

Alternate Number: AG0.98627 


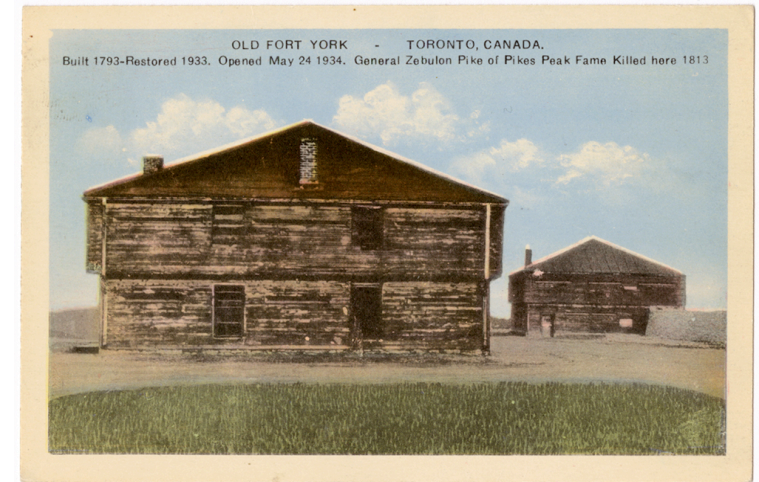

Recto

AGO Accession Number: 2011/163

Classification: Photography Collection Constituents:

Publisher: Toronto Convention and Tourist Assn.

Photographer: Unknown

Creator Note: Toronto Convention and

Tourist Association was founded in 1926

Title: Old Fort York - Toronto, Canada, built 1793 - Restored 1933. Opened May 24, 1934. General Zebulon Pike of Pikes Peak Fame Killed here 1813

Title Note: Printed

Date(s) of Object: [after 1934]

Date Notes: None

Object Name: Postcard

Medium: Collotype

Dimensions:

Image: $7.9 \times 12.7 \mathrm{~cm}, 3.11 \times 5.00 \mathrm{in}$

Sheet: $8.9 \times 13.7 \mathrm{~cm}, 3.50 \times 5.39$ in

\section{Geography:}

Place Created: unknown

Place Depicted: east of Bathurst Street, Toronto, Ontario on the shore of Lake Ontario

Mark(s): recto: titled; verso: publisher imprint, trademark, post template Inscriptions: verso: in graphite: [circled] 2242 l.l.

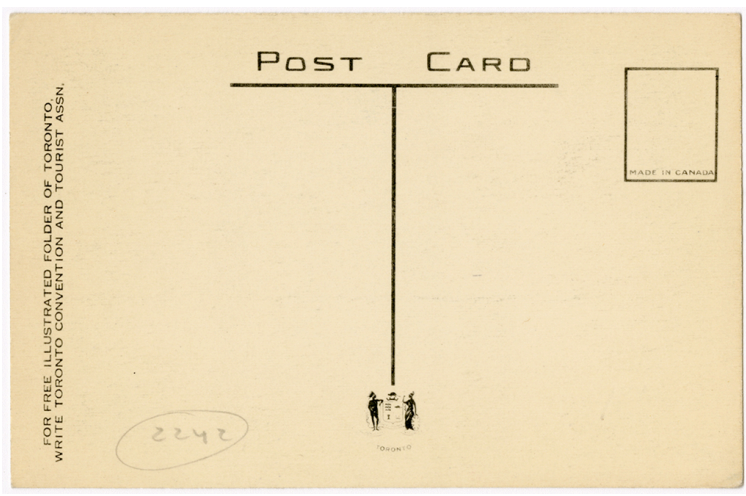

Verso

Notes: Authorized by Lieutenant Governor John Graves Simcoe the construction of the first Fort York located west of the mouth of Garrison Creek was built in 1793. Destroyed in the Battle of York, the Royal Engineers rebuilt the second fort after the War of 1812.

Alternate Number: AGO.986428 


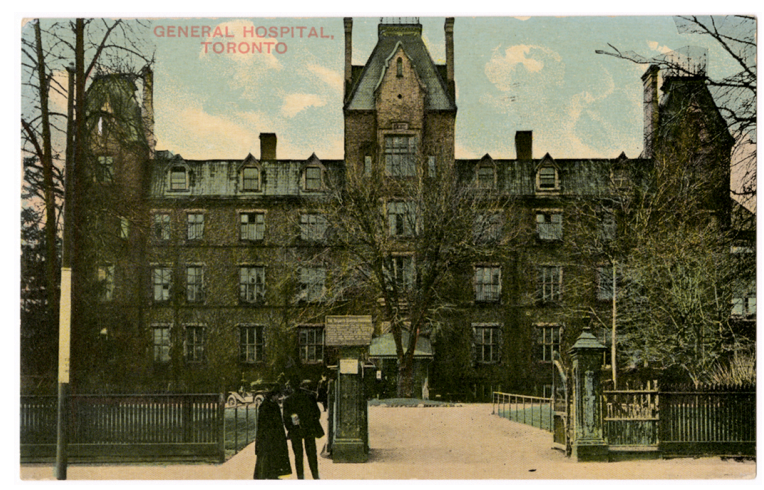

Recto

AGO Accession Number: 2011/164

Classification: Photography Collection Constituents:

Publisher: The Richmond Sales Co. Ltd. Toronto

Photographer: Unknown

Constituents Note: None

Title: General Hospital, Toronto

Title Note: Printed

Date(s) of Object: 1911

Date Notes: This card is postmarked

November 15

Object Name: Postcard

Medium: Letterpress halftone

Dimensions:

Image: $8.7 \times 13.7 \mathrm{~cm}, 3.43 \times 5.39$ in

Sheet: $8.7 \times 13.7 \mathrm{~cm}, 3.43 \times 5.39$ in

Geography:

Place Created: unknown

Place Depicted: Gerrard Street at

Sumach Street (NW), Toronto, Ontario

Mark(s): recto: titled; verso: publisher imprint, post template

Inscriptions: verso: ink, Dear Milly Did you get over to the concert - if not you will be surprised to hear I am in Toronto attending the Institute Convention. Your sincere friend D.M. Miss Milly Thompson Minden PO Ont, graphite, [no.] 2999

[circled] l.r.

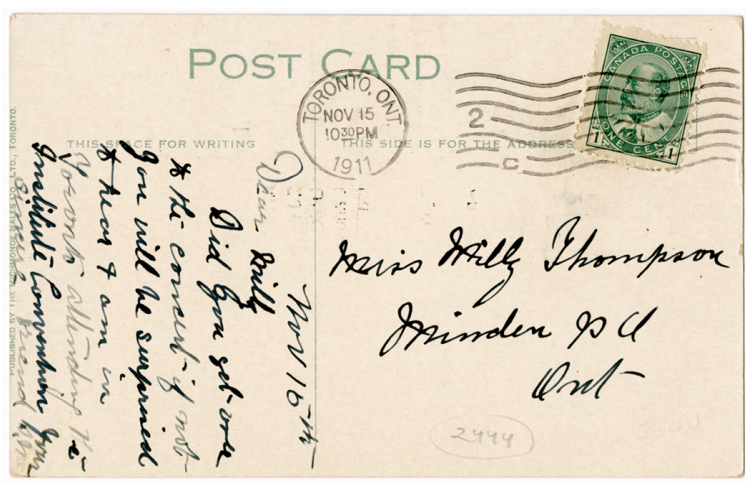

Verso

Notes: Designed by architect William Hay (1818-1888) The Toronto General

Hospital was constructed between 1854 and 1855. Operations continued until 1913 when the hospital relocated to the corner of College Street and University Avenue.

Alternate Number: AGO.98629 


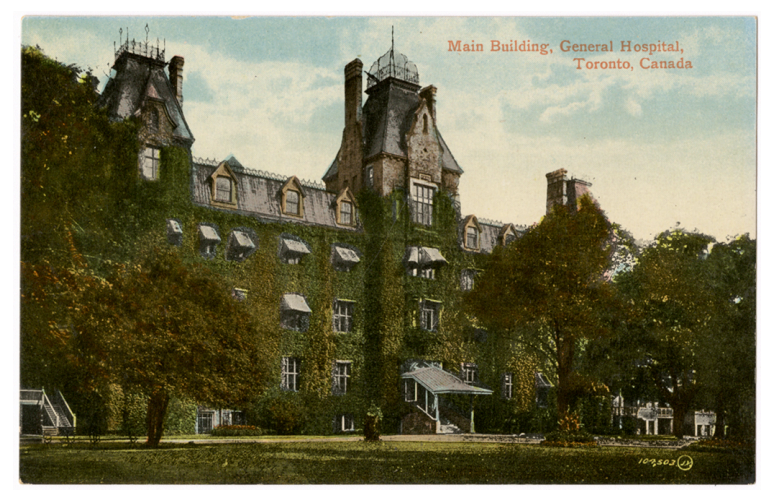

Recto

AG0 Accession Number: 2011/165

Classification: Photography Collection

Constituents:

Publisher: The Valentine \& Sons

Publishing Co. Ltd. Montreal and

Toronto

Photographer: Unknown

Constituents Note: The Valentine \& Sons

Publishing Co. Ltd. was founded in

Montreal and Toronto in 1903 and 1906

respectively. Operations were terminated in 1923.

Title: Main Building, General Hospital,

Toronto, Canada

Title Note: Printed

Date(s) of Object: [between 1908 and 1923]

Date Notes: This card was printed after the Valentine \& Sons began to use the 'FAMOUS THROUGHOUT THE WORLD' trademark in 1908.

Object Name: Postcard

Medium: Letterpress halftone

Dimensions:

Image: $8.7 \times 13.7 \mathrm{~cm}, 3.43 \times 5.39$ in

Sheet: $8.7 \times 13.7 \mathrm{~cm}, 3.43 \times 5.39$ in

Geography:

Place Created: Great Britain

Place Depicted: Gerrard Street at

Sumach Street (NW), Toronto, Ontario

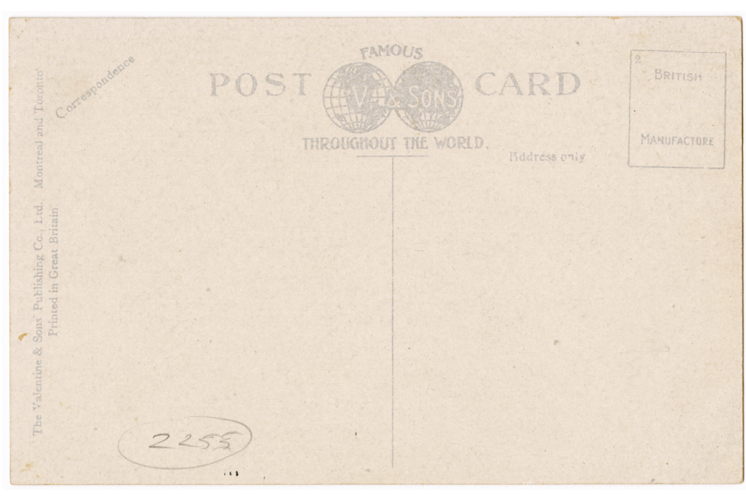

Verso

Mark(s): recto: titled, [no.] 104,503 JV

[circled]; verso: publisher imprint, trademark, post template

Inscriptions: verso: in graphite: [circled] 2255 l.l.

Notes: Designed by architect William Hay (1818-1888) The Toronto General Hospital was constructed between 1854 and 1855. Operations continued until 1913 when the hospital relocated to the corner of College Street and University Avenue in Toronto .

Alternate Number: AG0.98630 


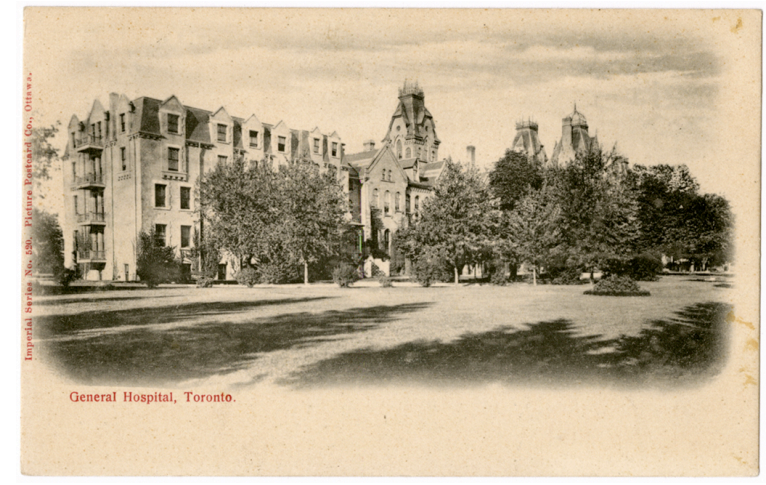

Recto

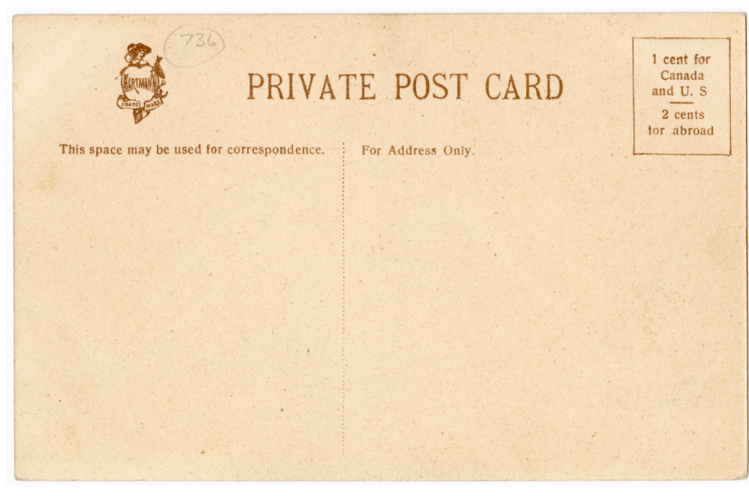

Verso

AGO Accession Number: 2011/166

Classification: Photography Collection

Constituents:

Publisher: Picture Postcard Co., Ottawa

Photographer: Unknown

\section{Constituents Note:}

Title: General Hospital, Toronto

Title Note: Printed

Date(s) of Object: [ca1915]

Date Notes: None

Object Name: Postcard

Medium: Collotype

Dimensions:

Image: $7.2 \times 13 \mathrm{~cm}, 2.83 \times 5.12$ in

Sheet: $8.7 \times 13.8 \mathrm{~cm}, 3.43 \times 5.43$ in

Geography:

Place Created: Unknown

Place Depicted: Gerrard Street at

Sumach Street (NW), Toronto, Ontario

Mark(s): recto: titled, Imperial Series No. 590; verso: trademark imprint "Hartman," post template

Inscriptions: verso: in graphite: [circled] 736 t.l.

Notes: Designed by architect William Hay (1818-1888) The Toronto General Hospital was constructed between 1854 and 1855. Operations continued until 1913 when the hospital relocated to the corner of College Street and University Avenue in Toronto.

Alternate Number: AG0.98631 


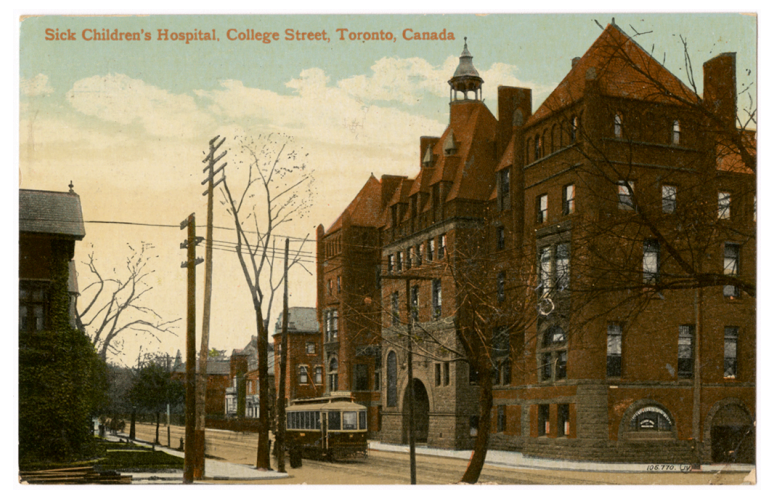

Recto

AGO Accession Number: 2011/167

Classification: Photography Collection Constituents:

Publisher: The Valentine \& Sons

Publishing Co. Ltd. Montreal and

Toronto

Photographer: Unknown

Constituents Note: The Valentine \& Sons

Publishing Co. Ltd. was founded in

Montreal and Toronto in 1903 and 1906

respectively. Operations were terminated in 1923.

Title: Sick Children's Hospital, College

Street, Toronto, Canada

Title Note: Printed

Date(s) of Object: [between 1908 and 1913]

Date Notes: The card is postmarked January 8, 1913 and was printed after Valentine \& Sons began to use the 'FAMOUS THROUGHOUT THE WORLD' trademark in 1908.

Object Name: Postcard

Medium: Letterpress halftone

Dimensions:

Image: $8.7 \times 13.7 \mathrm{~cm}, 3.43 \times 5.39$ in

Sheet: $8.7 \times 13.7 \mathrm{~cm}, 3.43 \times 5.39$ in

Geography:

Place Created: Great Britain

Place Depicted: College Street at

Elizabeth Street, Toronto, Ontario

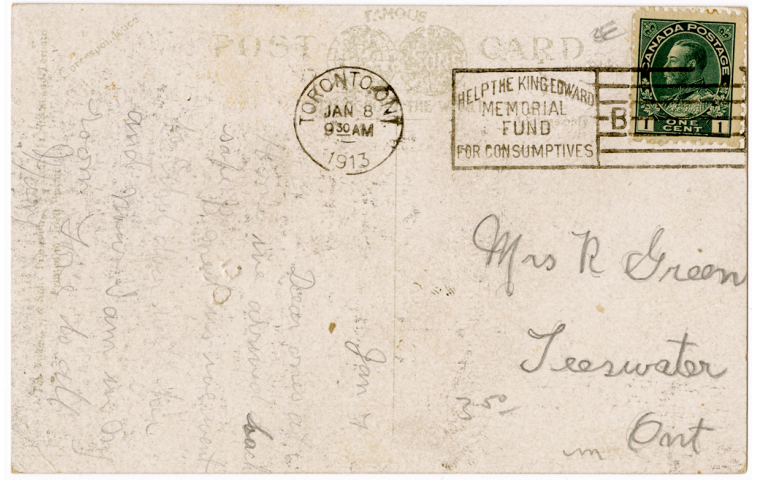

Verso

Mark(s): recto: titled, [no.] 106,770 JV [circled]; verso: publisher imprint, trademark, post template

Inscriptions: verso: in graphite: Jan 7

Dear ones at Home we arrived back safely [unreadable] us we went to Ethel door with her and now I am in my room Love to all Mary Mrs R Green Teeswater Ont; squiggly line l.r.; 2E t..r.

Notes: Designed by architects Frank Darling (1850-1923) and Samuel George Curry (1854-1942) the hospital was constructed between 1889 and 1891 .

Alternate Number: AG0.98632 


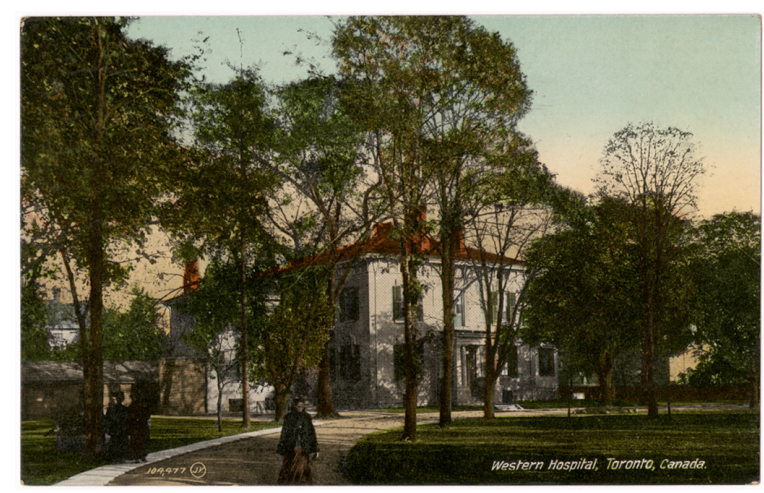

Recto

AG0 Accession Number: 2011/168

Classification: Photography Collection

Constituents:

Publisher: The Valentine \& Sons

Publishing Co. Ltd. Montreal and

Toronto

Photographer: Unknown

Constituents Note: The Valentine \& Sons

Publishing Co. Ltd. was founded in

Montreal and Toronto in 1903 and 1906

respectively. Operations were terminated in 1923.

Title: Western Hospital, Toronto, Canada

Title Note: Printed

Date(s) of Object: [between 1908 and 1910]

Date Notes: The card is postmarked May 10, 1910 and was printed after Valentine \& Sons began to use the 'FAMOUS THROUGHOUT THE WORLD’ trademark in 1908.

Object Name: Postcard

Medium: Letterpress halftone

Dimensions:

Image: $8.6 \times 13.7 \mathrm{~cm}, 3.39 \times 5.39$ in

Sheet: $8.6 \times 13.7 \mathrm{~cm}, 3.39 \times 5.39 \mathrm{in}$

\section{Geography:}

Place Created: Great Britain

Place Depicted: The James McConnell house known as "The Willows" located on the east side of Bathurst Street north of Dundas Street

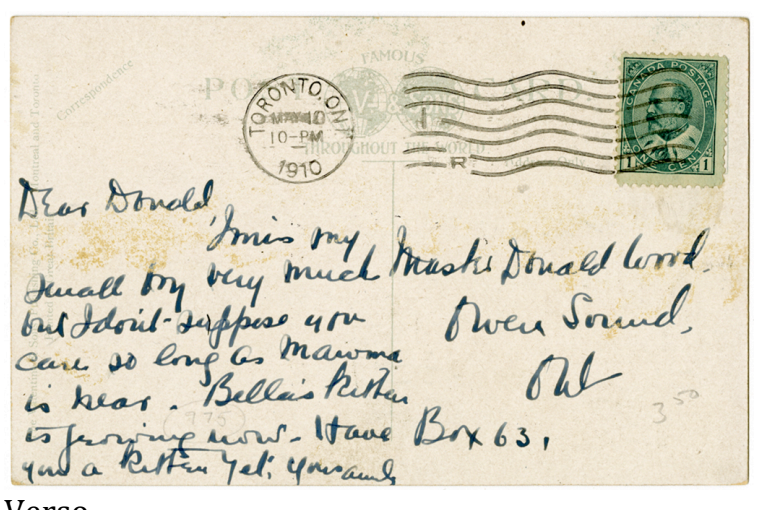

Verso

Mark(s): recto: titled, [no.] 104,477 JV

[circled], verso: publisher imprint, trademark, post template

Inscriptions: verso: in ink: Dear Donald I miss my small boy very much but I don't suppose you care so long as Mawma (?) is near. Bella's brother is growing now. Have you a kitten (?) yet Your aunt Master Donald Wood Owen Sound Ont. Box 63; in graphite: [no] 350 l.r.

Notes: Designed by William Sheard "The Willows" was constructed in 1856. In 1899 the governors of the Toronto Western Hospital purchased and renovated the house to be used as a hospital.

Alternate Number: AG0.98633 


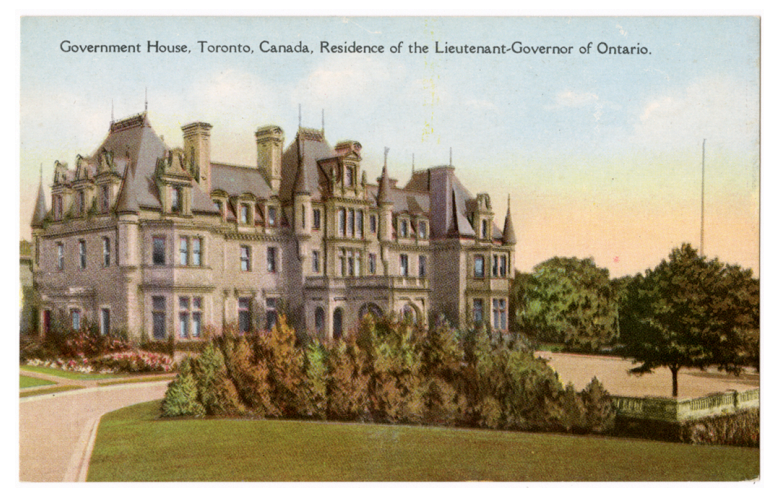

Recto

AGO Accession Number: 2011/169

Classification: Photography Collection Constituents:

Publisher: Post Card \& Greeting Card Co. Ltd. Toronto

Photographer: Unknown

Constituents Note: Post Card \& Greeting Card Co. Ltd. Toronto established during the 1920s terminated operations in 1935. Title: Government House, Toronto, Canada. Residence of the LieutenantGovernor of Ontario

Title Note: Printed

Date(s) of Object: [1920s]

Object Name: Postcard

Medium: Letterpress halftone

Dimensions:

Image: $8.7 \times 13.8 \mathrm{~cm}, 3.43 \times 5.43 \mathrm{in}$

Sheet: $8.7 \times 13.8 \mathrm{~cm}, 3.43 \times 5.43$ in

Geography:

Place Created: printed in Canada

Place Depicted: Roxborough Drive,

Toronto, Ontario

Mark(s): recto: titled; verso: publisher imprint, trademark 'Canada Series', post template

Inscriptions: None

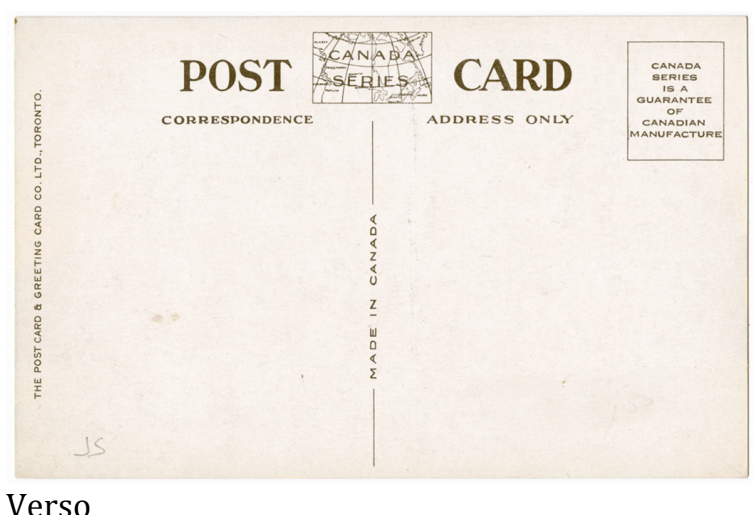

Notes: Designed by architect Francis Riley Heakes (1858-1930) in the French Renaissance style Government House was constructed between 1911 and 1915. The building was demolished in 1959.

Government House was also known as Chorley Park.

Alternate Number: AGO.98634 


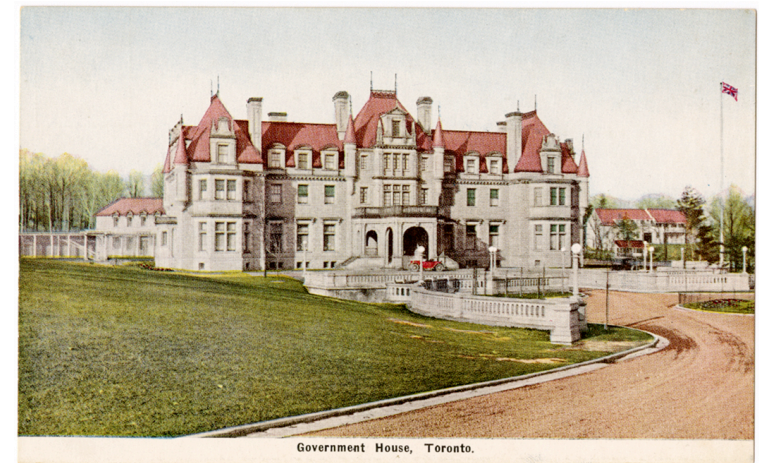

Recto

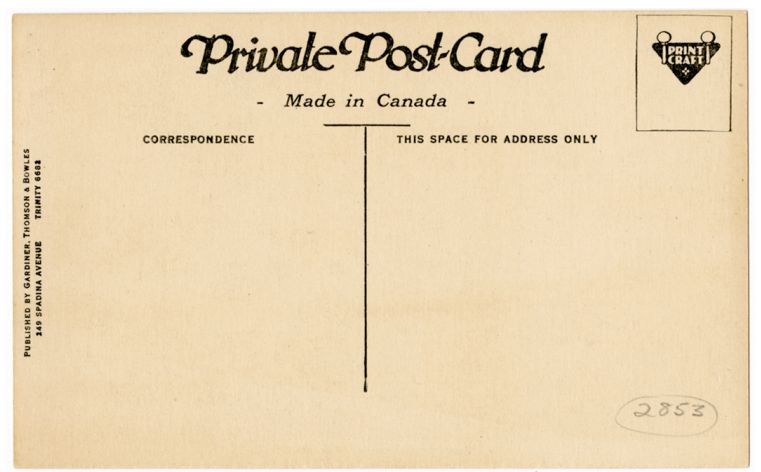

Verso

AGO Accession Number: 2011/170

Classification: Photography Collection

Constituents:

Publisher: Gardiner, Thomson \&

Bowles

Photographer: Unknown

Constituent Note: Gardiner, Thomson \&

Bowles maintained operations at 249

Spadina Avenue

Title: Government House, Toronto

Title Note: Printed

Date(s) of Object: [1920s]

Date Notes: None

Object Name: Postcard

Medium: Letterpress halftone

Dimensions:

Image: $8.1 \times 13.9 \mathrm{~cm}, 3.19 \times 5.47$ in

Sheet: $8.7 \times 13.9 \mathrm{~cm}, 3.19 \times 5.47$ in

Geography:

Place Created: Canada

Place Depicted: Roxborough Drive,

Toronto, Ontario

Mark(s): recto: titled; verso: publishers imprint, trademark 'Print Craft', post template, Trinity [no.] 6682

Inscriptions: verso: in graphite: [no.] 2853 [circled] l.r.

Notes: Designed by architect Francis

Riley Heakes (1858-1930) in the French

Renaissance style Government House was

constructed between 1911 and 1915. The building was demolished in 1959 .

Government House was also known as

Chorley Park.

Alternate Number: AGO.98635 


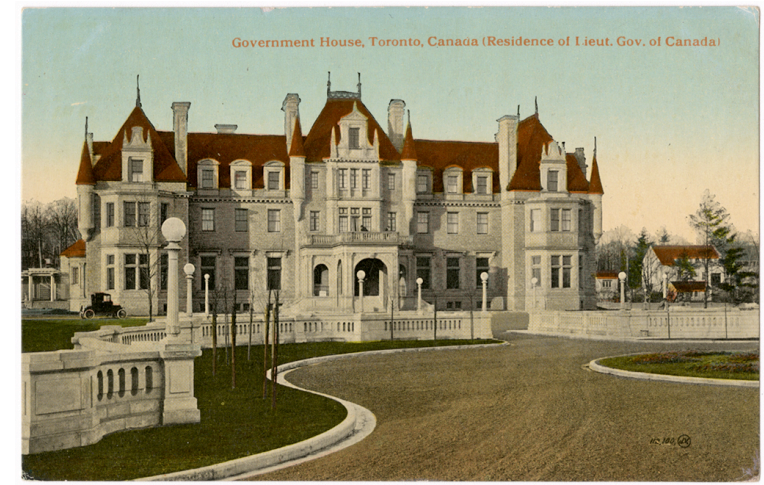

Recto

AGO Accession Number: 2011/171

Classification: Photography Collection

Constituents:

Publisher: The Valentine \& Sons

Publishing Co. Ltd. Montreal and

Toronto

Photographer: Unknown

Constituents Note: The Valentine \& Sons

Publishing Co. Ltd. was founded in

Montreal and Toronto in 1903 and 1906

respectively. Operations were terminated in 1923.

Title: Government House, Toronto, Canada (Residence of Lieut. Gov. of Canada)

Title Note: Printed

Date(s) of Object: [between 1908 and

1923]

Date Notes: This card was printed after the Valentine \& Sons began to use the 'FAMOUS THROUGHOUT THE WORLD' trademark in 1908.

Object Name: Postcard

Medium: Rotogravure

Dimensions:

Image: $8.8 \times 13.7 \mathrm{~cm}, 3.46 \times 5.39$ in

Sheet: $8.8 \times 13.7 \mathrm{~cm}, 3.46 \times 5.39$ in

Geography:

Place Created: Great Britain

Place Depicted: Roxborough Drive,

Toronto, Ontario

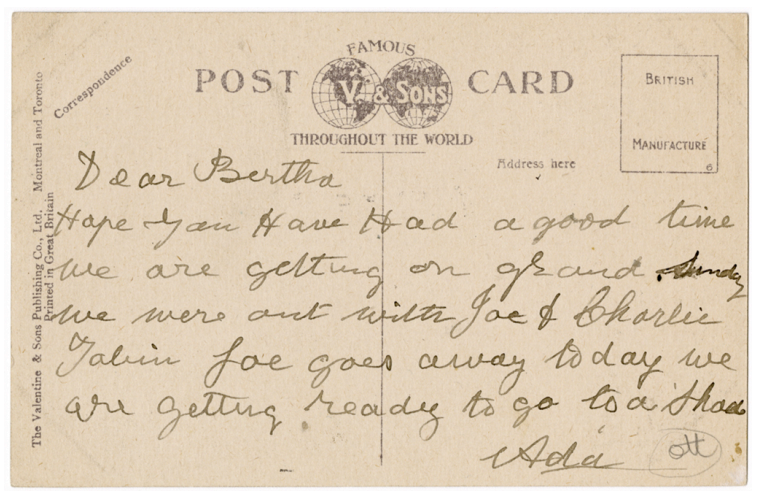

Verso

Mark(s): recto: titled, [no.] 112,100 JV [circled]; verso: publisher imprint, trademark, post template

Inscriptions: verso: in ink: Dear Bertha Hope you have had a good time. We are getting on grand. Sunday we were out with Joe \& Charlie. Tabin (?) Joe goes away today we are getting ready to go to a show. Ada; in graphite: ott [circled] l.r. Notes: Designed by architect Francis Riley Heakes (1858-1930) in the French Renaissance style Government House was constructed between 1911 and 1915. The building was demolished in 1959.

Government House was also known as Chorley Park.

Alternate Number: AG0.98636 


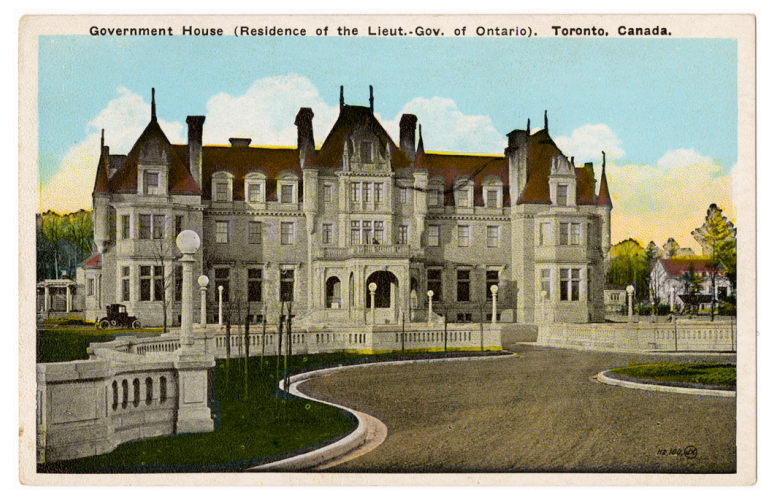

Recto

AGO Accession Number: 2011/172

Classification: Photography Collection Constituents:

Publisher: The Valentine \& Sons United Publishing Co. Limited Toronto and Winnipeg

Photographer: Unknown Constituents Note: The Valentine \& Sons Publishing Co. Ltd. was founded in Montreal and Toronto in 1903 and 1906 respectively. Operations were terminated in 1923.

Title: Government House (Residence of the Lieut. Gov. of Ontario). Toronto, Canada.

Title Note: Printed

Date(s) of Object: [between 1915 and 1930]

Date Notes: Postcards printed with a white border were produced between 1915 and 1930.

Object Name: Postcard

Medium: Letterpress halftone

Dimensions:

Image: $8.3 \times 13.2 \mathrm{~cm}, 3.27 \times 5.20$ in Sheet: $8.9 \times 13.9 \mathrm{~cm}, 3.27 \times 5.20$ in

Geography:

Place Created: U. S. A.

Place Depicted: Roxborough Drive, Toronto, Ontario

Mark(s): recto: titled, [no.] 112,100 JV

[circled]; verso: publisher imprint, trademark, post template

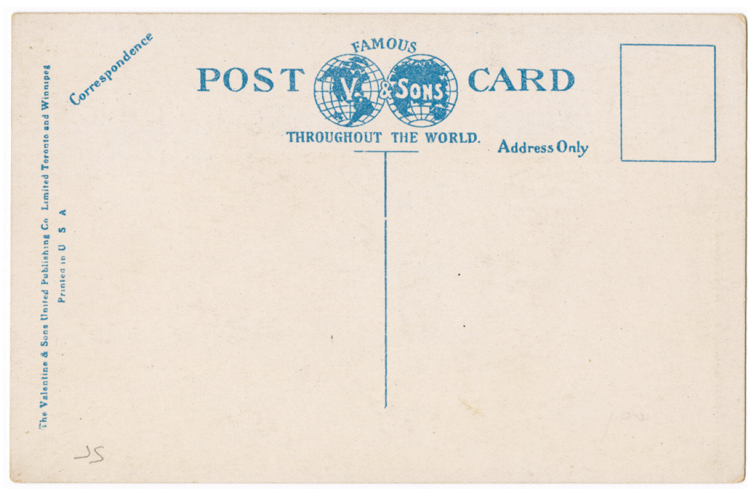

Verso

Inscriptions: None

Notes: Designed by architect Francis Riley Heakes (1858-1930) in the French Renaissance style Government House was constructed between 1911 and 1915. The building was demolished in 1959.

Government House was also known as Chorley Park.

Alternate Number: AG0.98637 


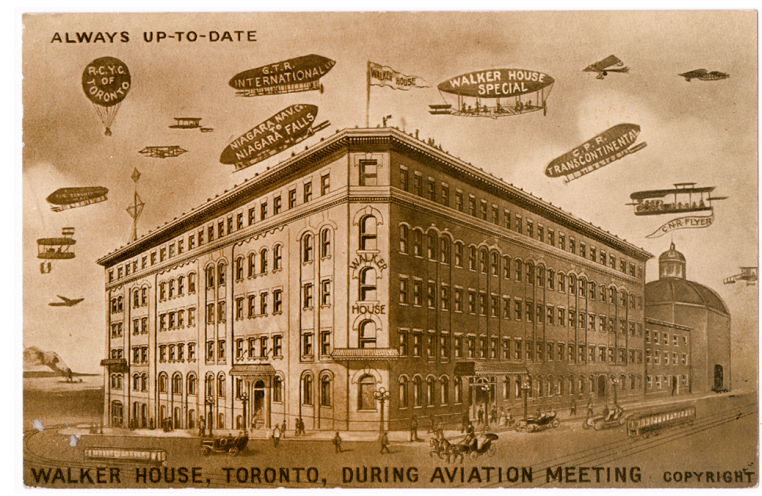

Recto

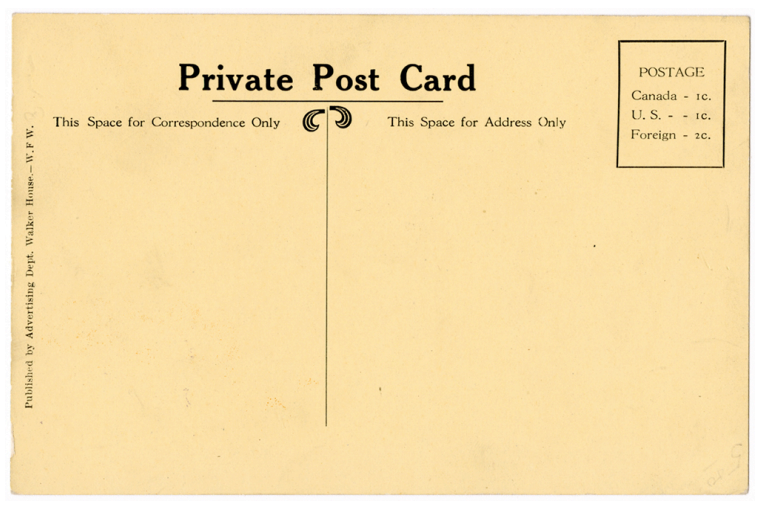

Verso

AGO Accession Number: 2011/173

Classification: Photography Collection

Constituents:

Publisher: Advertising Dept. Walker

House - W. F. W.

Photographer: Unknown

Constituents Note: Walker House Hotel maintained operations in Toronto, ON

Canada from 1876 to 1976

Title: Walker House, Toronto, During

Aviation Meeting

Title Note: Printed

Date(s) of Object: [after 1910]

Date Notes: Aviation meets presenting aircraft to the public occurred after 1910 in Toronto and Montreal.

Object Name: Postcard

Medium: Letterpress halftone

Dimensions:

Image: $8.8 \times 13.4 \mathrm{~cm}, 3.46 \times 5.28 \mathrm{in}$

Sheet: $8.8 \times 13.4 \mathrm{~cm}, 3.46 \times 5.28$ in

\section{Geography:}

Place Created: Canada

Place Depicted: Front and York Streets (NE)

Mark(s): recto: titled, imprinted:

ALWAYS UP-TO-DATE t.l., COPYRIGHT l.r.

Inscriptions: None

Notes: Walker House Hotel designed by

William Stewart (1832-1907) was

constructed in 1873 and demolished in 1976.

Alternate Number: AGO.98638 


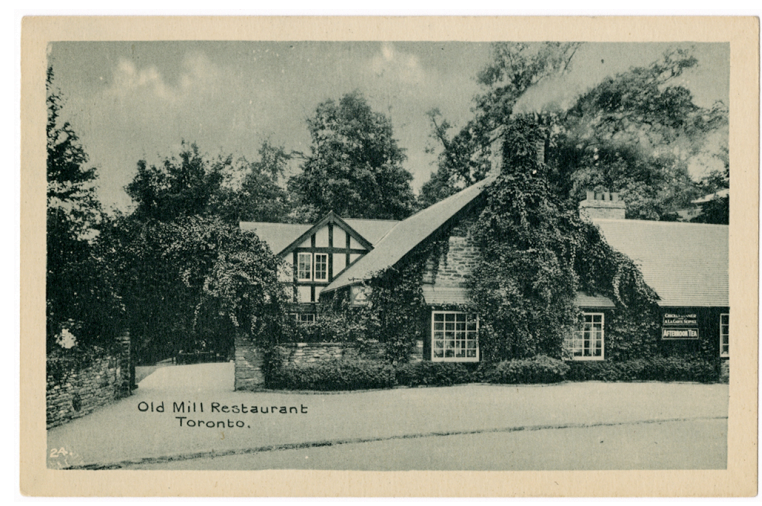

Recto

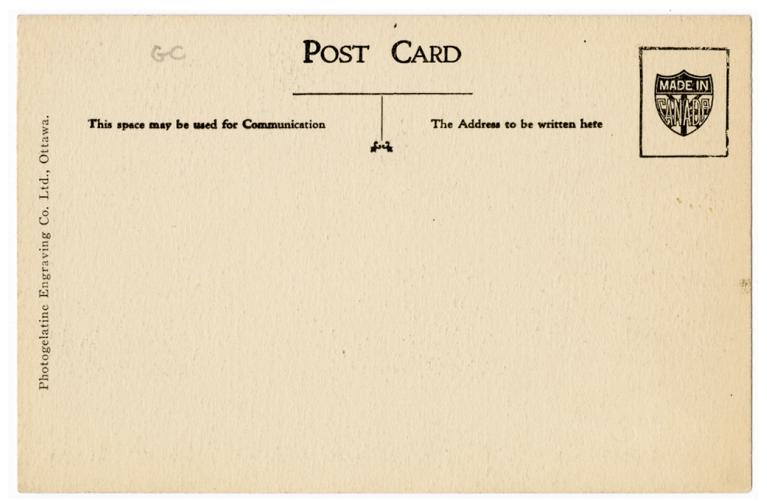

Verso

AGO Accession Number: 2011/174

Classification: Photography Collection Constituents:

Publisher: Photogelatine Engraving Co., Ltd., Ottawa

Photographer: Unknown

Constituents Note: The Photogelatine

Engraving Co., Ltd., Ottawa was founded in 1910 and maintained operations until 1953

Title: Old Mill Restaurant Toronto.

Title Note: Printed Date(s) of Object: [between 1915 and 1930]

Date Notes: Postcards with a white border were first introduced in 1915 and produced until 1930.

Object Name: Postcard

Medium: Collotype

Dimensions:

Image: $7.8 \times 12.6 \mathrm{~cm}, 3.07 \times 4.96$ in

Sheet: $8.8 \times 13.6 \mathrm{~cm}, 3.46 \times 5.35 \mathrm{in}$

Geography:

Place Created: Canada

Place Depicted: 21 Old Mill Road,

Toronto, Ontario

Mark(s): recto: titled, [no.] 24 l.l.; verso: publishers imprint, trademark 'MADE IN CANADA', post template

Inscriptions: verso: in graphite: GC t.l.

Notes: Robert Home Smith, an entrepreneur of the Kingsway area, built The Old Mill restaurant and "Tea Room" in 1914.

Alternate Number: AGO.98639 


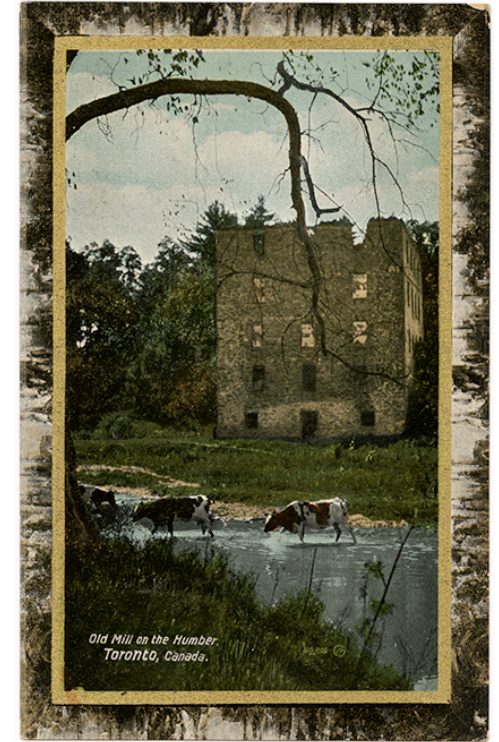

Recto

AGO Accession Number: 2011/175

Classification: Photography Collection Constituents:

Publisher: The Valentine \& Sons

Publishing Co. Ltd. Montreal and

Toronto

Photographer: Unknown

Constituent Note: The Valentine \& Sons

Publishing Co. Ltd. was founded in

Montreal and Toronto in 1903 and 1906

respectively. Operations were terminated in 1923.

Title: Old Mill on the Humber, Toronto, Canada

Title Note: Printed

Date(s) of Object: [between 1908 and 1923]

Date Notes: This card was printed after the Valentine \& Sons began to use the 'FAMOUS THROUGHOUT THE WORLD' trademark in 1908.

Object Name: Postcard

Medium: Rotogravure with gilt

Dimensions:

Image: $12.2 \times 7.1 \mathrm{~cm}, 4.80 \times 2.80 \mathrm{in}$

Sheet: $14.0 \times 9.0 \mathrm{~cm}, 5.51 \times 3.54$ in

Geography:

Place Created: Great Britain

Place Depicted: West bank of the

Humber River

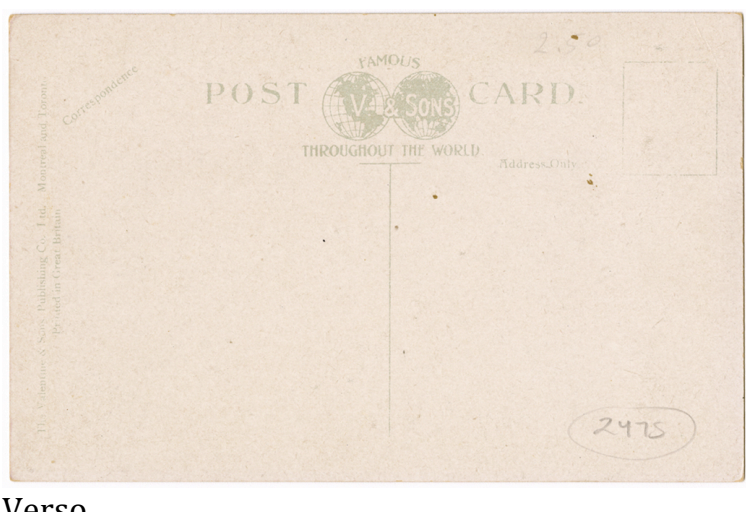

Verso

Mark(s): recto: titled, [no.] 100,809 JV

[circled]; verso: publisher imprint, trademark, post template

Inscriptions: verso: in graphite: [no.] 2475 [circled] l.r.

Notes: William Tyrell (1816-ca1928)

built the seven-story mill for William

Gamble in 1848. It was destroyed by fire in 1881.

Alternate Number: AG0.98640 


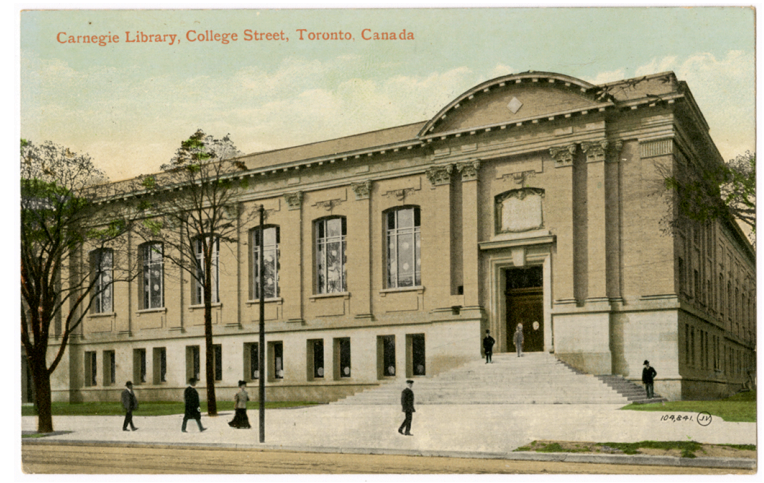

Recto

AG0 Accession Number: 2011/176

Classification: Photography Collection

Constituents:

Publisher: The Valentine \& Sons

Publishing Co. Ltd. Montreal and

Toronto

Photographer: Unknown

Constituents Note: The Valentine \& Sons

Publishing Co. Ltd. was founded in

Montreal and Toronto in 1903 and 1906

respectively. Operations were terminated in 1923.

Title: Carnegie Library, College Street,

Toronto, Canada

Title Note: Printed

Date(s) of Object: [between 1909 and 1923]

Date Notes: The Toronto Central Library opened in 1909.

Object Name: Postcard

Medium: Rotogravure

Dimensions:

Image: $8.8 \times 13.8 \mathrm{~cm}, 3.46 \times 5.47 \mathrm{in}$

Sheet: $8.8 \times 13.8 \mathrm{~cm}, 3.46 \times 5.47 \mathrm{in}$

Geography:

Place Created: Great Britain

Place Depicted: 214 College Street at

St. George Street (NW), Toronto,

Ontario

Mark(s): recto: titled, [no.] 104,841 JV

[circled]; verso: publisher imprint,

trademark, post template

Inscriptions: None
Verso

Notes: Designed by architects Alfred Hirschfelder Chapman (1879-1949), Alexander Frank Wickson (1861-1936) and William Rufus Gregg (1851-1930) the Carnegie Library (officially known as the Toronto Public Reference Library) was constructed between 1906 and 1909. Additions were constructed in 1922, 1928-9 and 1961. The building is now designated The University of Toronto Bookroom and Koffler Student Centre Alternate Number: AG0.98641 


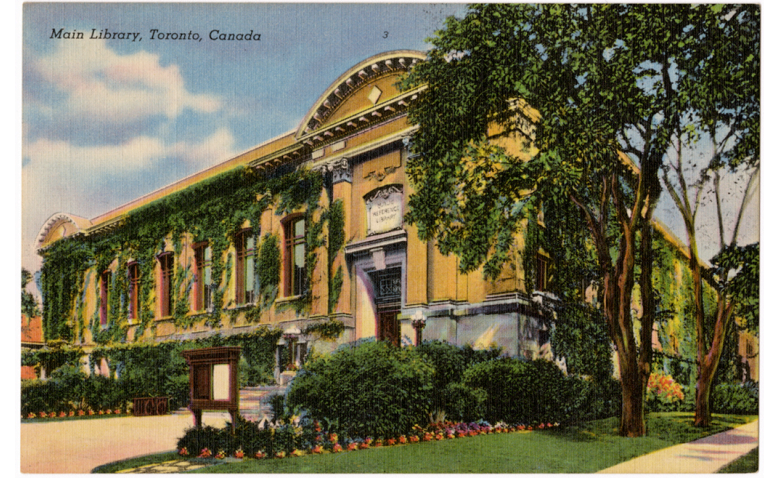

Recto

AGO Accession Number: 2011/177

Classification: Photography Collection

Constituents:

Publisher: Royal Specialty Sales Co.

Photographer: Unknown

Constituents Note: The Royal Specialty

Sales Co. was founded in 1937 and presently maintains operations in East

York, Toronto.

Title: Main Library, Toronto, Canada

Title Note: Printed

Date(s) of Object: [after 1937]

Date Notes: Royal Specialty Sales Co. was founded in 1937

Object Name: Postcard

Medium: Offset lithograph

Dimensions:

Image: $8.8 \times 13.8 \mathrm{~cm}, 3.46 \times 5.43 \mathrm{in}$

Sheet: $8.8 \times 13.8 \mathrm{~cm}, 3.46 \times 5.43 \mathrm{in}$

Geography:

Place Created: Boston, Mass. U.S.A.

Place Depicted: 214 College Street at

St. George Street (NW), Toronto,

Ontario

Mark(s): recto: titled; verso: publisher imprint, 120 Queen E., Toronto, Canada, [no.] K1320, printer's address BOSTON 15, MASS., U. S. A.

Inscriptions: None

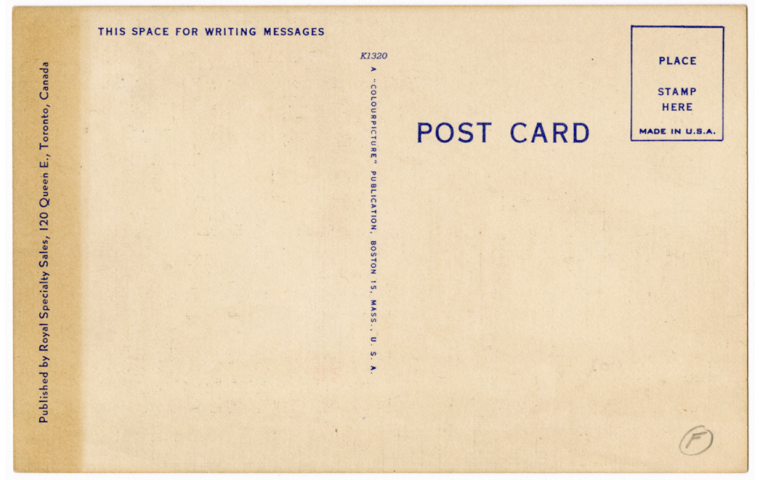

Verso

Notes: Designed by architects Alfred Hirschfelder Chapman (1879-1949), Alexander Frank Wickson (1861-1936) and William Rufus Gregg (1851-1930) the Carnegie Library (officially known as the Toronto Public Reference Library) was constructed between 1906 and 1909. Additions were constructed in 1922, 1928-9 and 1961. The building is now designated The University of Toronto Bookroom and Koffler Student Centre Alternate Number: AG0.98642 


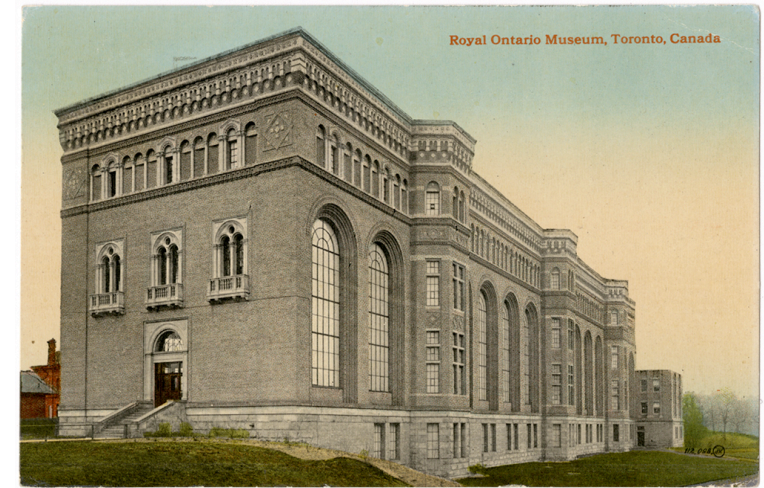

Recto

AGO Accession Number: 2011/178

Classification: Photography Collection Constituents:

Publisher: The Valentine \& Sons

Publishing Co. Ltd. Montreal and

Toronto

Photographer: Unknown

Constituents Note: The Valentine \& Sons

Publishing Co. Ltd. was founded in

Montreal and Toronto in 1903 and 1906

respectively. Operations were terminated in 1923.

Title: Royal Ontario Museum, Toronto, Canada

Title Note: Printed

Date(s) of Object: [between 1908 and 1917]

Date Notes: The card is postmarked April 30, 1917 and was printed after Valentine \& Sons began to use the 'FAMOUS THROUGHOUT THE WORLD' trademark in 1908.

Object Name: Postcard

Medium: Rotogravure

Dimensions:

Image: $9.0 \times 13.7 \mathrm{~cm}, 3.54 \times 5.39$ in

Sheet: $9.0 \times 13.7 \mathrm{~cm}, 3.54 \times 5.39$ in

Geography:

Place Created: Great Britain

Place Depicted: 100 Queens Park at

Bloor Street (SW), Toronto, Ontario

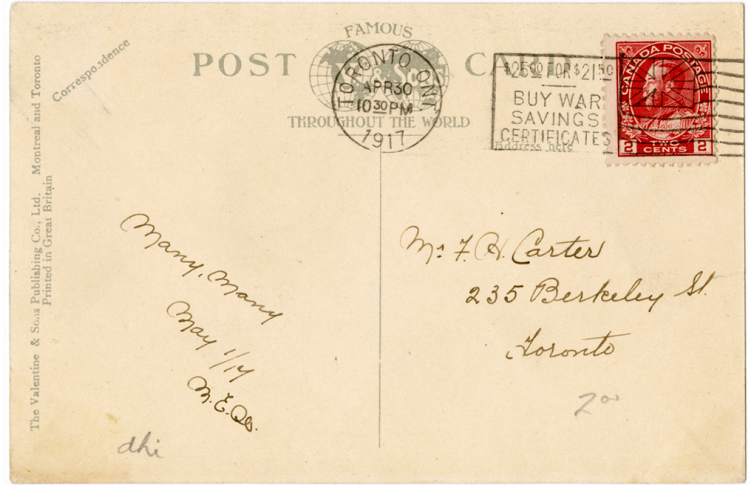

Verso

Mark(s): recto: titled, [no.] 112,098 JV [circled]; verso: publisher imprint, trademark, post template

Inscriptions: verso: in ink: Many, Many May 1/17 M. E. Q. (?) Mr. F. H. Carter 235 Berkeley St. Toronto; in graphite dhi l.l. Notes: Designed by architects Frank Darling (1850-1923) and John Andrew Pearson (1867-1940) the Royal Ontario Museum was constructed between 1910 and 1911 in the Italianate NeoRomanesque style.

Alternate Number: AGO.98643 


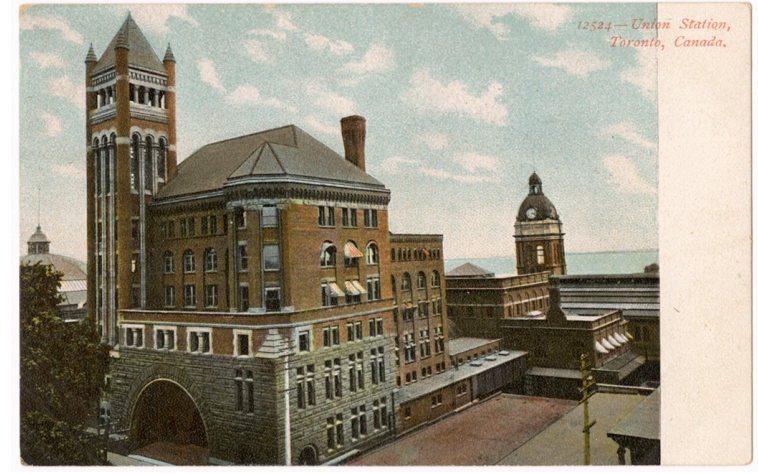

Recto

AGO Accession Number: 2011/179

Classification: Photography Collection

Constituents:

Publisher: Souvenir Post Card Co. New

York and Berlin

Photographer: Unknown

Constituents Note: Souvenir Post Card

Co. was founded in 1905 and terminated operations in 1914

Title: 12524 - Union Station, Toronto,

Canada

Title Note: Printed

Date(s) of Object: [between 1905 and 1914]

Date Notes: Souvenir Post Card Co.

maintained operations between 1905 and 1914.

Object Name: Postcard

Medium: Rotogravure

Dimensions:

Image: $8.7 \times 12.0 \mathrm{~cm}, 3.43 \times 4.72$ in

Sheet: $8.7 \times 13.7 \mathrm{~cm}, 3.43 \times 5.39$ in

Geography:

Place Created: Germany

Place Depicted: Southside of Front

Street near Simcoe Street

Mark(s): recto: titled; verso: publisher imprint, post template

Inscriptions: None

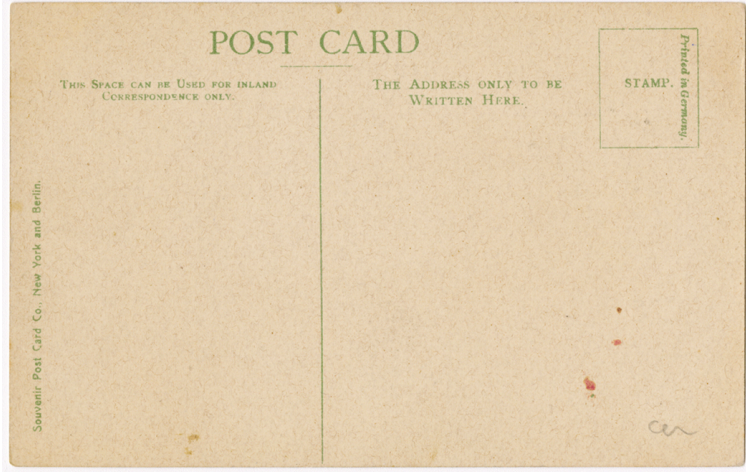

Verso

Notes: Designed by architects Walter Reginald Strickland (1841-1915) and William Limbery Symons (1870-1931) the addition to the second Union Station designed by Thomas Seaton Scott (18261895) with Edward P. Hannaford was constructed in 1893-94 in the Romanesque Revival style and demolished in 1927.

Alternate Number: AGO.98644 


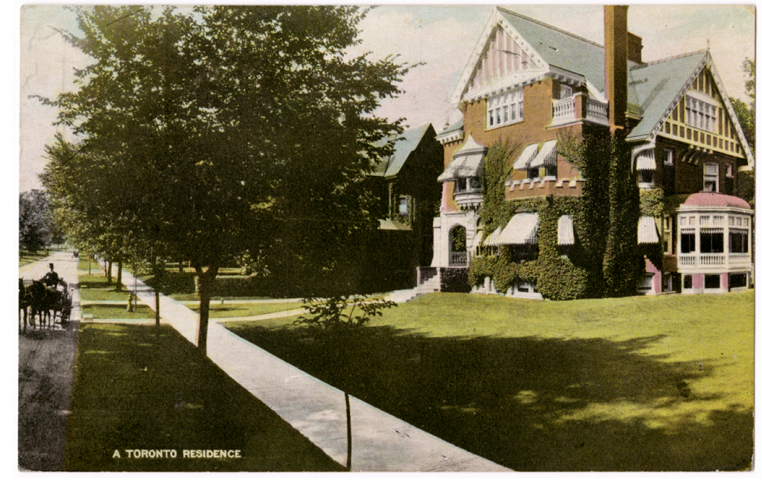

Recto

AGO Accession Number: 2011/180

Classification: Photography Collection

Constituents:

Publisher: Warwick Bro's \& Rutter

Limited, Printers, Toronto

Photographer: Unknown

Constituents Note: Warwick Bro's \&

Rutter Limited, Printers maintained

operations in Toronto from 1848 to 1933

and produced postcards between 1903

and 1912.

Title: A Toronto Residence

Title Note: Printed

Date(s) of Object: 1907

Date Notes: The card is postmarked

August 3, 1907

Object Name: Postcard

Medium: Letterpress halftone

Dimensions:

Image: $8.9 \times 13.9 \mathrm{~cm}, 3.50 \times 5.47$ in

Sheet: $8.9 \times 13.9 \mathrm{~cm}, 3.50 \times 5.47 \mathrm{in}$

Geography:

Place Created: Toronto, Ontario

Place Depicted: Unknown

Mark(s): recto: titled; verso: publishers

imprint, trademark 'CANADIAN

SOUVENIR POST CARD’, [no.] 4707 (?), post template

Inscriptions: verso: in ink: 99 Gerrard St.

E. Dear Grace I guess you think me long

(?) enough in airs I have been very busy

since I came here. My, the off. is going

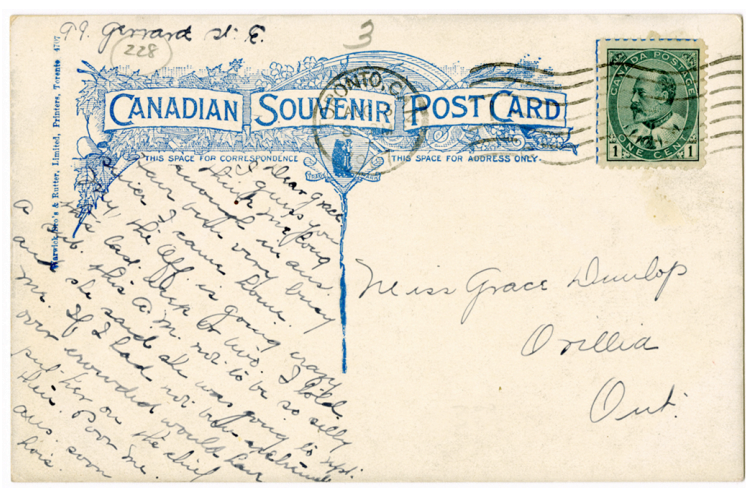

Verso

crazy this last week or two. I told a sub. this a.m. not to be so silly and she said she was going to rept. me. If I had not been extremely over crowded would have put her on the chief [H]eir (?) Poor me. Ans. soon Lois Miss Grace Dunlop Orillia Ont.; in graphite [no.] 228 [circled] t.l.

Notes: None

Alternate Number: AG0.98645 


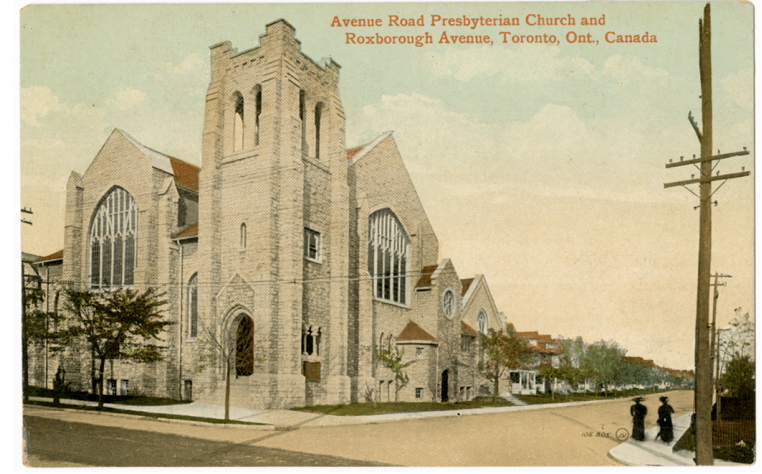

Recto

AGO Accession Number: 2011/181

Classification: Photography Collection

\section{Constituents:}

Publisher: The Valentine \& Sons

Publishing Co. Ltd. Montreal and

Toronto

Photographer: Unknown

Constituents Note: The Valentine \& Sons

Publishing Co. Ltd. was founded in

Montreal and Toronto in 1903 and 1906

respectively. Operations were terminated in 1923.

Title: Avenue Road Presbyterian Church and Roxborough Avenue, Toronto, Ont., Canada

Title Note: Printed

Date(s) of Object: [between 1908 and 1923]

Date Notes: This card was printed after the Valentine \& Sons began to use the 'FAMOUS THROUGHOUT THE WORLD' trademark in 1908.

Object Name: Postcard

Medium: Rotogravure

Dimensions:

Image: $8.6 \times 13.6 \mathrm{~cm}, 3.39 \times 5.35$ in

Sheet: $8.6 \times 13.6 \mathrm{~cm}, 3.39 \times 5.35 \mathrm{in}$

\section{Geography:}

Place Created: Great Britain

Place Depicted: Avenue Road at

Roxborough Street West

\section{Verso}

Mark(s): recto: titled, [no.] 106,805 JV [circled]; verso: publisher imprint, trademark, post template Inscriptions: verso: in graphite: RE [circled]

Notes: Designed by Henry Bauld Gordon (1854-1951) and Grant Helliwell (18551953) the church was constructed in 1897-99 in the Norman-Gothic style. Originally named the Presbyterian Church of the Covenant the church was renamed the Avenue Road Presbyterian Church in 1902.

Alternate Number: AG0.98646 


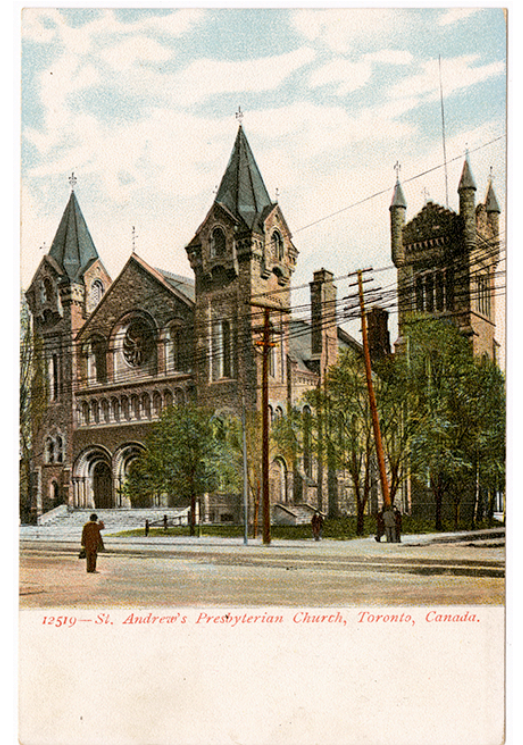

Recto

AGO Accession Number: 2011/182

Classification: Photography Collection Constituents:

Publisher: Souvenir Post Card Co. New York and Berlin

Photographer: Unknown

Constituents Note: Souvenir Post Card

Co. New York and Berlin maintained operation at 268 Canal Street, New York between 1905 and 1914

Title: 12519 - St. Andrew's Presbyterian Church, Toronto, Canada

Title Note: Printed

Date(s) of Object: [between 1905 and 1914]

Date Notes: Souvenir Post Card Co.

maintained operations between 1905 and 1914.

Object Name: Postcard

Medium: Letterpress halftone

Dimensions:

Image: $10.9 \times 8.8 \mathrm{~cm}, 4.29 \times 3.46$ in

Sheet: $13.4 \times 8.8 \mathrm{~cm}, 5.28 \times 3.46$ in

Geography:

Place Created: Germany

Place Depicted: Southeast corner of

King Street West at Simcoe Street

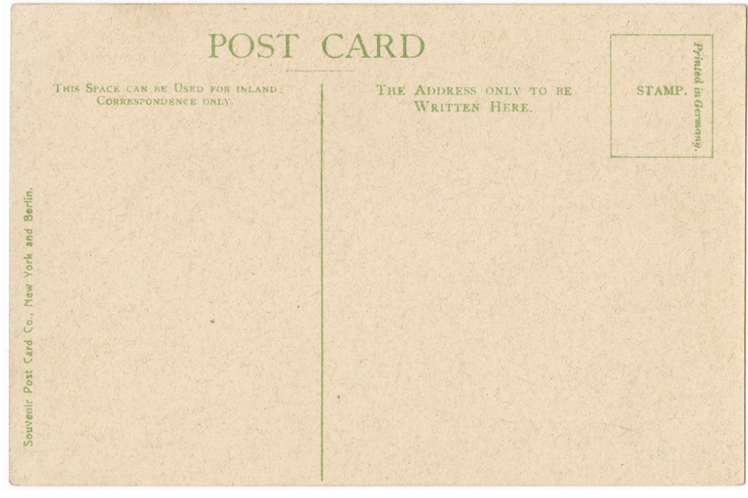

Verso

Mark(s): recto: titled; verso: publisher imprint, post template Inscriptions: None

Notes: Designed by William George Storm (1826-1892) and incorporating romantic features related to the Church of Scotland, the building was constructed in 1874-75 with alterations and additions undertaken in 1880.

Alternate Number: AGO.98647 


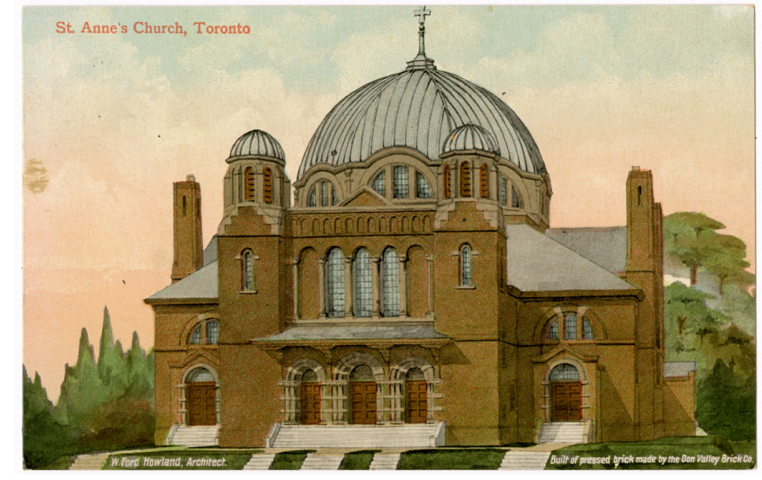

Recto

AGO Accession Number: 2011/183

Classification: Photography Collection

Constituents:

Publisher: Unknown

Photographer: Unknown

Constituents Note: None

Title: St. Anne's Church, Toronto

Title Note: Printed

Date(s) of Object: 1911

Date Notes: The is card is postmarked

May 29, 1911

Object Name: Postcard

Medium: Letterpress halftone

Dimensions:

Image: $8.7 \times 13.6 \mathrm{~cm}, 3.43 \times 5.35 \mathrm{in}$

Sheet: $8.7 \times 13.6 \mathrm{~cm}, 3.43 \times 5.35$ in

Geography:

Place Created: Great Britain

Place Depicted: Gladstone Avenue at

Dundas Street West

Mark(s): recto: titled, Printed 'W. Ford Howland Architect - Built of pressed brick made by Don Valley Brick Co.'; verso: post template

Inscriptions: verso: Dear Miss Chapman a card as promised. I would have written before but have been awfully busy. Hope you are quite well with kind regards Sincerely yours Walter Lovegrove 18 High Park Ave, I would be pleased to hear from you W. Lovegrove, Miss L. Chapman West Toronto Post Office City; in graphite: BA [circled] l.r.

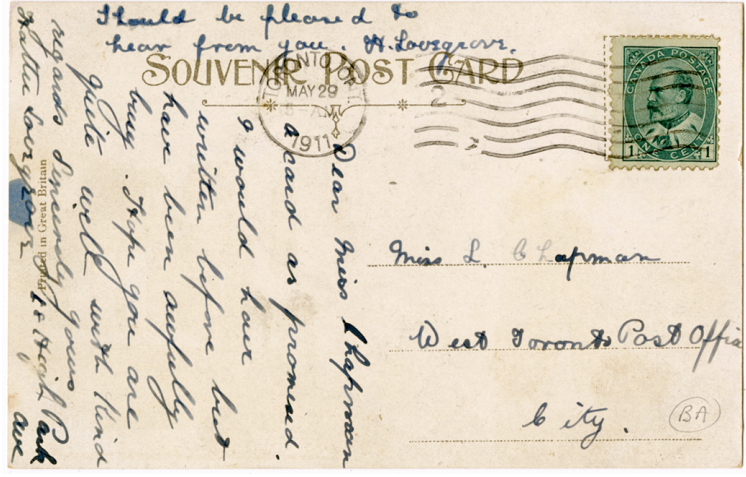

Verso

Notes: Designed by architect William Ford Howland (1874-1948) with Edmund Burke (1850-1919) and John Charles Batstone (1864-1938) St. Anne's Church was constructed in the Byzantine Revival style in 1907-08.

Alternate Number: AGO.98648 


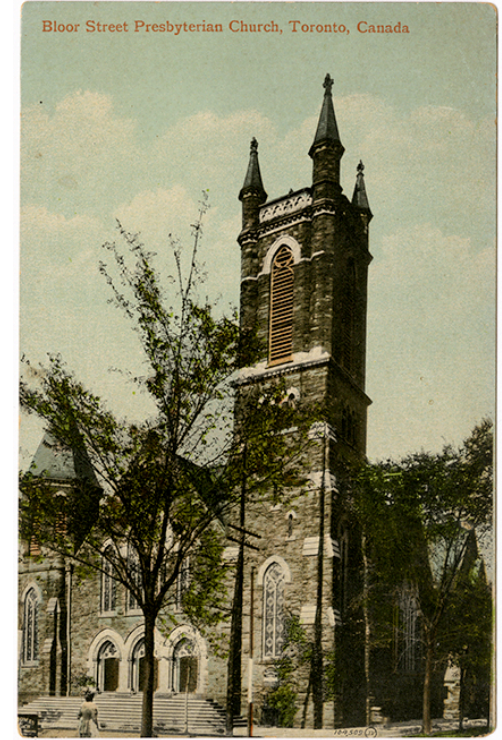

Recto

AGO Accession Number: 2011/184

Classification: Photography Collection Constituents:

Publisher: The Valentine \& Sons

Publishing Co. Ltd. Montreal and

Toronto

Photographer: Unknown

Constituents Note: The Valentine \& Sons

Publishing Co. Ltd. was founded in

Montreal and Toronto in 1903 and 1906

respectively. Operations were terminated in 1923.

Title: Bloor Street Presbyterian Church, Toronto, Canada

Title Note: Printed

Date(s) of Object: [between 1908 and

1923]

Date Notes: This card was printed after the Valentine \& Sons began to use the 'FAMOUS THROUGHOUT THE WORLD' trademark in 1908.

Object Name: Postcard

Medium: Letterpress halftone

Dimensions:

Image: $13.7 \times 8.8 \mathrm{~cm}, 5.39 \times 3.46$ in

Sheet: $13.7 \times 8.8 \mathrm{~cm}, 5.39 \times 3.46$ in

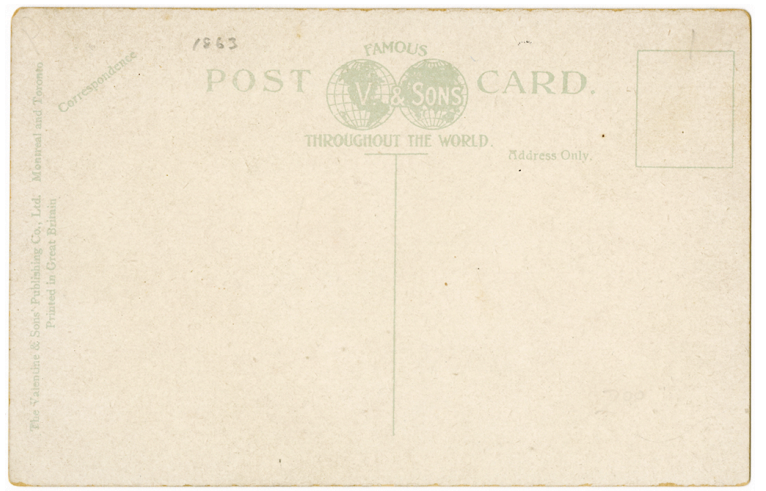

Verso

\section{Geography:}

Place Created: Great Britain

Place Depicted: Bloor Street at Huron

Street (NW)

Mark(s): recto: titled, [no.] 104,509 JV

[circled]; verso: publisher imprint, trademark, post template

Inscriptions: verso: in graphite: [no.] 1863 t.l.

Notes: Designed by architect William Rufus Gregg (1851-1930) the Bloor Street Presbyterian Church was constructed in 1889-90.

Alternate Number: AG0.98649 


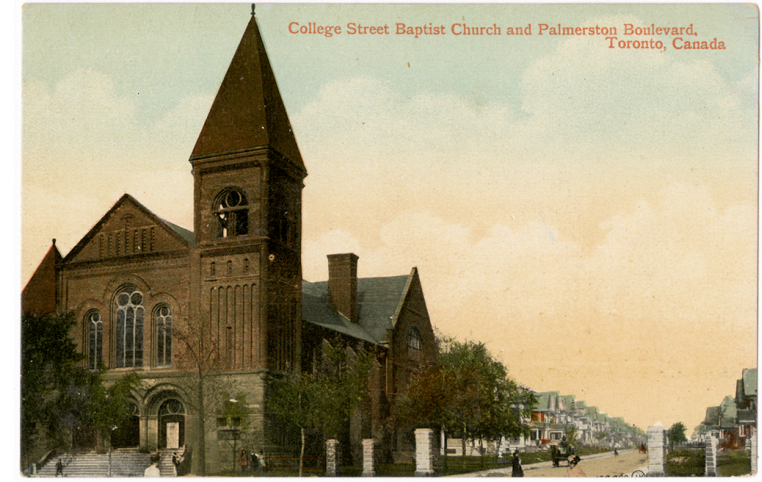

Recto

AGO Accession Number: 2011/185

Classification: Photography Collection Constituents:

Publisher: The Valentine \& Sons

Publishing Co. Ltd. Montreal and Toronto

Photographer: Unknown Constituents Note: The Valentine \& Sons Publishing Co. Ltd. was founded in Montreal and Toronto in 1903 and 1906 respectively. Operations were terminated in 1923.

Title: College Street Baptist Church and Palmerston Boulevard, Toronto, Canada Title Note: Printed Date(s) of Object: [between 1908 and 1923]

Date Notes: This card was printed after the Valentine \& Sons began to use the 'FAMOUS THROUGHOUT THE WORLD' trademark in 1908.

Object Name: Postcard

Medium: Letterpress halftone

Dimensions:

Image: $8.7 \times 13.6 \mathrm{~cm}, 3.43 \times 5.35$ in

Sheet: $8.7 \times 13.6 \mathrm{~cm}, 3.43 \times 5.35$ in

Geography:

Place Created: Great Britain

Place Depicted: College Street at

Palmerston Avenue (NW)

Mark(s): recto: titled; verso: publisher imprint, trademark, post template Inscriptions: verso: in graphite: W12 [circled] l.r.

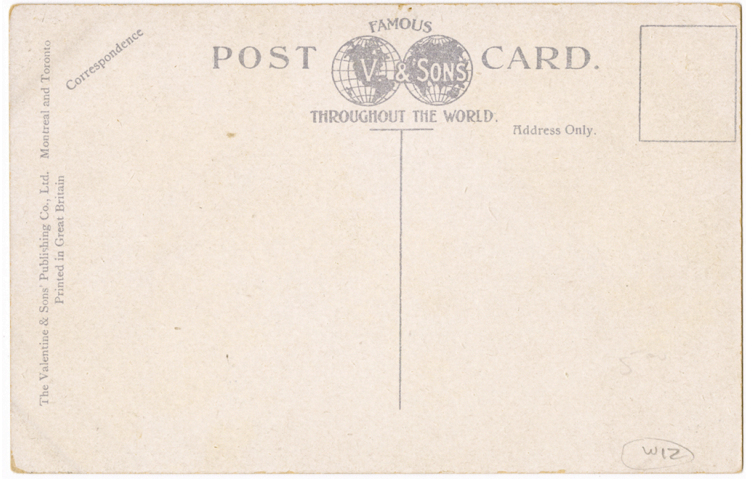

Verso

Notes: Designed by architects Henry Langley (1836-1907) and Edmund Burke (1850-1919) College Street Baptist Church was constructed in 1889-90. Palmerston Boulevard was named after Lord Henry John Temple Palmerston (1784-1865) at the turn of the twentieth century. He was known as "Firebrand Palmerston".

Alternate Number: AGO.98650 


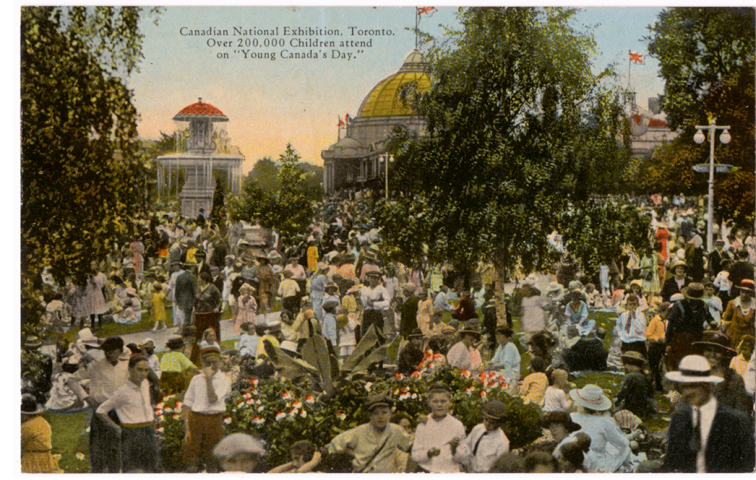

Recto

AGO Accession Number: 2011/186

Classification: Photography Collection

Constituents:

Publisher: E. Zaitchick, Canadian

National Exhibition, Toronto

Photographer: Unknown

Constituents Note: E. Zaitchick and Sons

Co. was a concessionaire at the CNE from

1923 onwards.

Title: Canadian National Exhibition,

Toronto. Over 200,000 Children attend on "Young Canada's Day."

Title Note: Printed

Date(s) of Object: [after 1923]

Date Notes: E. Zaitchick and Sons Co. was a concessionaire at the CNE from 1923 onwards.

Object Name: Postcard

Medium: Letterpress halftone

Dimensions:

Image: $8.7 \times 13.6 \mathrm{~cm}, 3.43 \times 5.35$ in

Sheet: $8.7 \times 13.6 \mathrm{~cm}, 3.43 \times 5.35 \mathrm{in}$

Geography:

Place Created: C. T. Photochrom, Chicago, U. S. A

Place Depicted: A view of the grounds of the Canadian National Exhibition looking southwest toward Lake Ontario Mark(s): recto: titled; verso: publisher imprint, trademark 'C.T. Chicago', post template [no.] a-98488 c.t.

Inscriptions: None

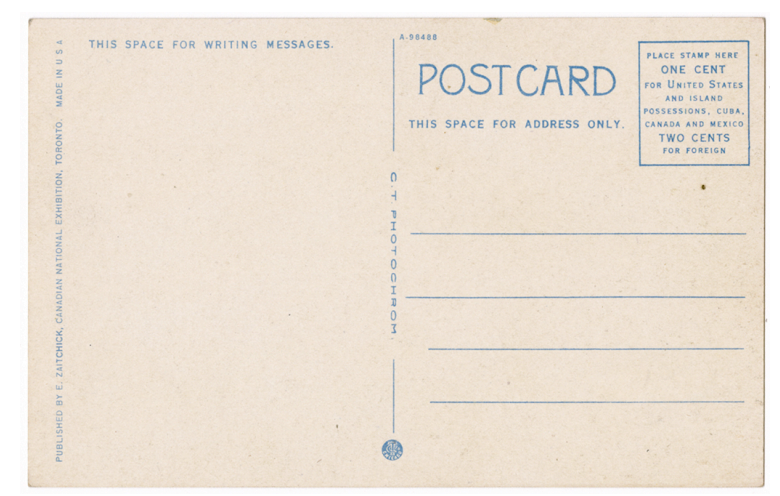

Verso

Notes: In the distance on the left side is the Gooderham Fountain named after George H. Gooderman, the president of the CNE Association from 1909 to 1911. The Gooderham Fountain was constructed in 1910 and was replaced with the Princess Margaret Fountain in 1958. Left of centre is the Horticultural Building designed by Architect George William Gouinlock (1861-1932) the Horticultural Building constructed in 1906-07 and restored in 1981.

Alternate Number: AG0.98651 


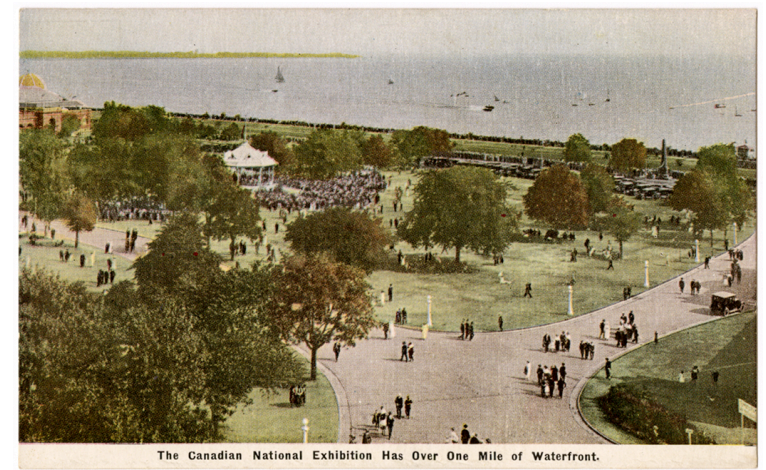

Recto

AGO Accession Number: 2011/187

Classification: Photography Collection Constituents:

Publisher: Gardiner, Thomson \& Bowles

Photographer: Unknown

Constituents Note: Gardiner, Thomson \&

Bowles maintained operations at 249

Spadina Avenue

Title: The Canadian National Exhibition Has Over One Mile of Waterfront.

Title Note: Printed

Date(s) of Object: [after 1912]

Date Notes: The Toronto Industrial

Exhibition was renamed the Canadian

National Exhibition in 1912.

Object Name: Postcard

Medium: Letterpress halftone

Dimensions:

Image: $8.2 \times 13.9 \mathrm{~cm}, 3.23 \times 5.47 \mathrm{in}$

Sheet: $8.7 \times 13.9 \mathrm{~cm}, 3.43 \times 5.47$ in

Geography:

Place Created: Canada

Place Depicted: An aerial view of the grounds of the Canadian National Exhibition taken from the Horticultural Building looking south towards Lake Ontario

Mark(s): recto: titled; verso: publishers imprint, trademark 'Print Craft', post template, Trinity [no.] 6682

Inscriptions: verso: in graphite: $\mathrm{SH}$ [circled] l.r.

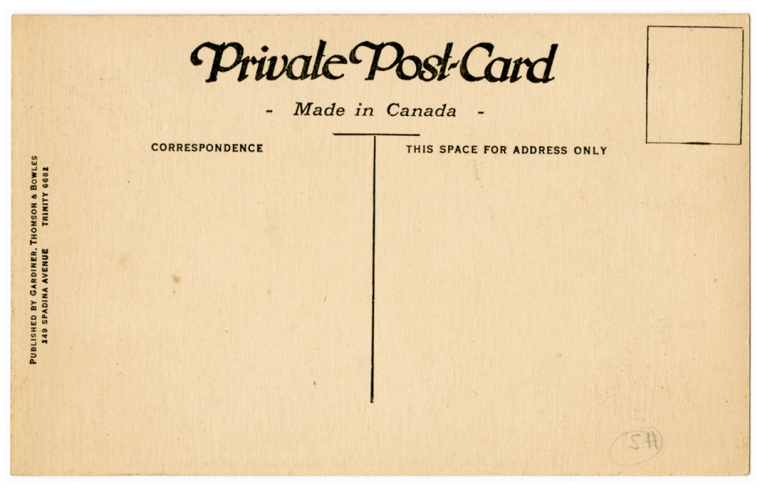

Verso

Notes: In the distance on the left is the Manufacturers and Liberal Arts Building designed by Architect George William Gouinlock (1861-1932) the Manufacturers and Liberal Arts Building was constructed in 1902. The Women's Building was added to the original building in 1908. It was destroyed by fire in 1961 and replaced by the Better Living Centre designed by the architectural firm of Marani, Morris \& Allan (1959-1964) in 1962

Alternate Number: AGO.98652 


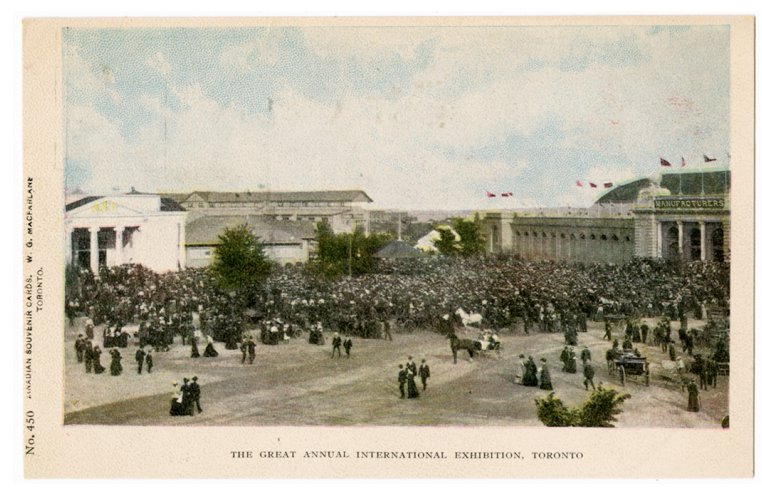

Recto

AG0 Accession Number: 2011/188

Classification: Photography Collection Constituents:

Publisher: W. G. MacFarlane Publishing Co. Ltd. Toronto

Photographer: Unknown

Constituents Note: The W. G. MacFarlane Publishing Co. Ltd. Toronto maintained offices in Toronto commencing in 1899 and published postcards between 1902 and 1910.

Title: The Great Annual International Exhibition, Toronto

Title Note: Printed Date(s) of Object: [between 1903 and 1910]

Date Notes: The W. G. MacFarlane Publishing Co. Ltd. produced postcards between 1902 and 1910. The International Exhibition was renamed the Canadian National Exhibition in 1912. In Canada Postal Regulations permitted the production of divided postcards

Object Name: Postcard

Medium: Letterpress halftone

Dimensions:

Image: $7.6 \times 12.7 \mathrm{~cm}, 2.99 \times 5.00 \mathrm{in}$

Sheet: $8.8 \times 13.9 \mathrm{~cm}, 3.46 \times 5.47$ in

Geography:

Place Created: unknown

Place Depicted: A view of the grounds

of the Canadian National Exhibition

taken from the location of the

Horticultural Building

\section{Private POST CaRd.}

Verso

Mark(s): recto: titled, publishers imprint, trademark 'Canadian Souvenir Cards', [no.] No. 450; verso: post template Inscriptions: None

Notes: On the left side of the image is the Art Gallery designed by Architect Edgar Beaumont Jarvis (1864-1948) in the Beaux Arts style. It was constructed in 1902 and demolished in 1955. It was later named The Graphic Arts and Photography Building after a second art gallery was constructed in 1905 . To the right of the Art Gallery is the Dairy Building designed by Architect George William Gouinlock (1861-1932) and was constructed in 1903. In the distance is the second Grandstand constructed in 1895. To the rights is the Manufacturers and Liberal Arts Building designed by Gouinlock and constructed in 1902. The Women's Building was added to the original building in 1908. It was destroyed by fire in 1961 and replaced by the Better Living Centre designed by the architectural firm of Marani, Morris \& Allan (1959-1964) in 1962.

Alternate Number: AG0.98653 


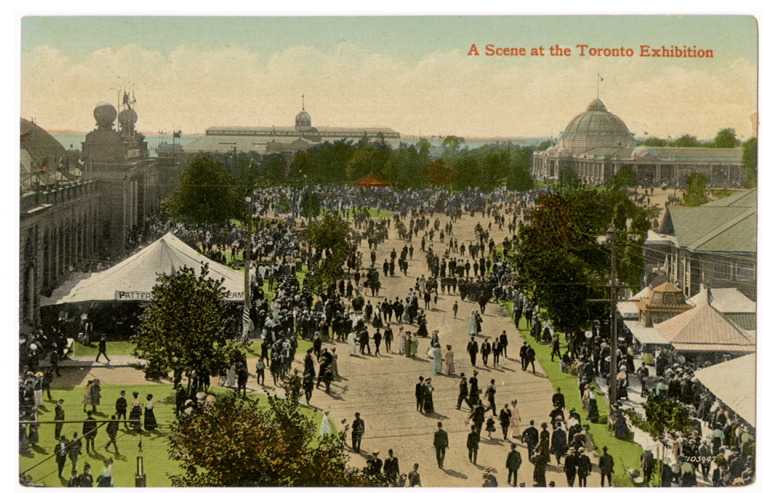

Recto

AGO Accession Number: 2011/189

Classification: Photography Collection Constituents:

Publisher: The Valentine \& Sons

Publishing Co. Ltd. Montreal and

Toronto

Photographer: Unknown

Constituents Note: The Valentine \& Sons

Publishing Co. Ltd. was founded in

Montreal and Toronto in 1903 and 1906

respectively. Operations were terminated in 1923

Title: A Scene at the Toronto Exhibition

Title Note: Printed

Date(s) of Object: [between 1908 and 1912]

Date Notes: This card was printed after the company began to use the 'FAMOUS THROUGHOUT THE WORLD' trademark in 1908. The Toronto Industrial Exhibition was renamed the Canadian National Exhibition in 1912.

Object Name: Postcard

Medium: Letterpress halftone

Dimensions:

Image: $8.8 \times 13.7 \mathrm{~cm}, 3.46 \times 5.39 \mathrm{in}$

Sheet: $8.8 \times 13.7 \mathrm{~cm}, 3.46 \times 5.39$ in

Geography:

Place Created: Great Britain

Place Depicted: A view of the grounds of Canadian National Exhibition looking west towards Lake Ontario
Verso

Mark(s): recto: titled, [no.] 105947;

verso: publisher imprint, trademark, post template

Inscriptions: verso: in graphite: 2382 [circled] l.l.

Notes: Along the left side is the Manufacturers and Liberal Arts Building designed by Architect George William Gouinlock (1861-1932) and constructed in 1902. The Women's Building was added to the original building in 1908. It was destroyed by fire in 1961 and replaced by the Better Living Centre designed by the architectural firm of Marani, Morris \& Allan (1959-1964) in 1962. In the distance is the Transportation Building designed by Gouinlock and constructed in 1909. It was destroyed by fire in 1974. The site is now occupied by Bandshell Park. In the middle distance on the right is the Horticultural Building designed by Gouinlock and constructed in 1906-07 and restored in 1981.

Alternate Number: AG0.98654 


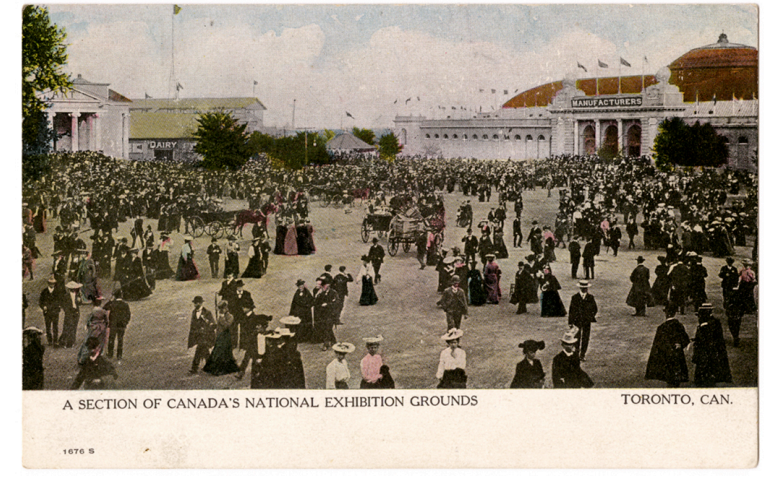

Recto

AGO Accession Number: 2011/190

Classification: Photography Collection

Constituents:

Publisher: Warwick Bro's \& Rutter, Limited, Publishers, Toronto

Photographer: Unknown

Constituents Note: Warwick Bro's \&

Rutter, Limited maintained operations in

Toronto from 1860 to 1972 and

published postcards between 1903 and

1912

Title: A Section Of Canada's National

Exhibition Grounds - Toronto, Can.

Title Note: Printed

Date(s) of Object: 1912

Date Notes: The Toronto Industrial

Exhibition was renamed the Canadian

National Exhibition in 1912.

Object Name: Postcard

Medium: Letterpress halftone

Dimensions:

Image: $7.3 \times 13.9 \mathrm{~cm}, 2.87 \times 5.47 \mathrm{in}$

Sheet: $8.8 \times 13.9 \mathrm{~cm}, 3.46 \times 5.47 \mathrm{in}$

Geography:

Place Created: Toronto, Ontario

Place Depicted: A view of the grounds

of the Canadian National Exhibition

looking east

Mark(s): recto: titled, [no.] 1676 S l.l.; verso: publishers imprint, trademark 'Canadian Souvenir Post Card', post template

Inscriptions: None

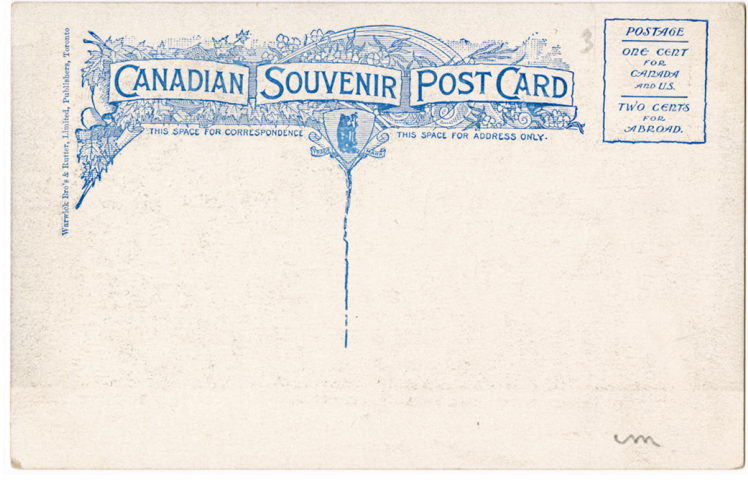

Verso

Notes: Located in the upper left is the Art Gallery designed by Architect Edgar Beaumont Jarvis (1864-1948) in the Beaux Arts style constructed in 1902. After 1905 it was known as The Graphic Arts and Photography Building. It was demolished in 1955. To the right is Dairy Building designed by Architect George William Gouinlock (1861-1932) and constructed in 1903. On the rights side is the Manufacturers and Liberal Arts Building designed by Gouinlock was constructed in 1902. The Women's Building was added to the original building in 1908. It was destroyed by fire in 1961 and replaced by the Better Living Centre designed by the architectural firm of Marani, Morris \& Allan (1959-1964) in 1962. In the distance is the second Grandstand constructed in 1895.

Alternate Number: AG0.98655 


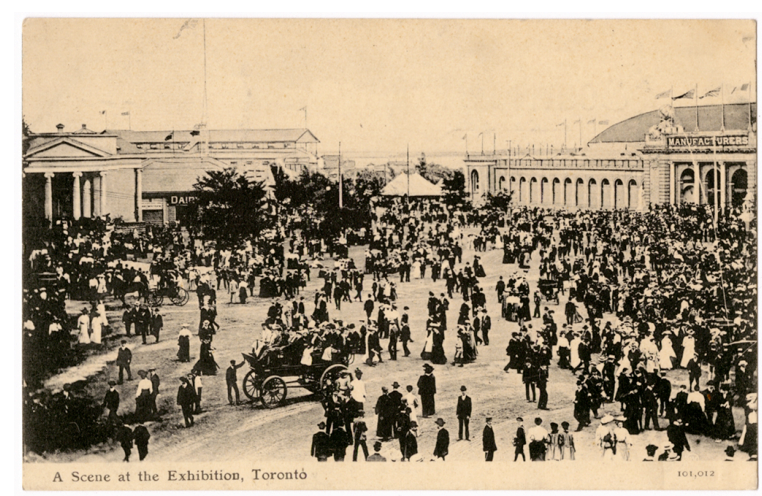

Recto

AGO Accession Number: 2011/191

Classification: Photography Collection

Constituents:

Publisher: The Valentine \& Sons

Publishing Co. Ltd. Montreal and

Toronto

Photographer: Unknown

Constituents Note: The Valentine \& Sons

Publishing Co. Ltd. was founded in

Montreal and Toronto in 1903 and 1906

respectively. Operations were terminated in 1923.

Title: A Scene at the Exhibition, Toronto

Title Note: Printed

Date(s) of Object: [between 1907 and 1912]]

Date Notes: This card was printed prior to when Valentine \& Sons began to use the 'FAMOUS THROUGHOUT THE WORLD' trademark in 1908.

Object Name: Postcard

Medium: Collotype

Dimensions:

Image: $8.4 \times 13.8 \mathrm{~cm}, 3.31 \times 5.43 \mathrm{in}$

Sheet: $8.8 \times 13.8 \mathrm{~cm}, 3.31 \times 5.43 \mathrm{in}$

\section{Geography:}

Place Created: Great Britain

Place Depicted: A view of the grounds of the Canadian National Exhibition looking east

Mark(s): recto: titled, [no.] 101,012 l.r.; verso: publisher imprint, trademark 'Souvenir Post Card', post template

\section{SOUVENIR POST GARD}

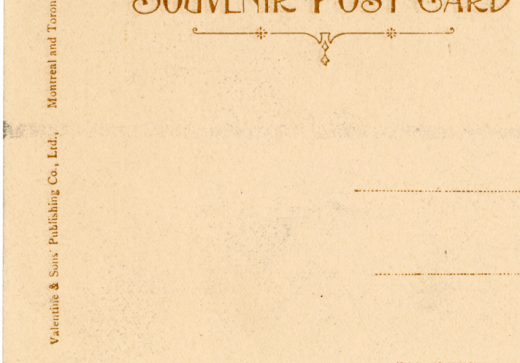

Verso

Inscriptions: None

Notes: Located in the upper left is the Art Gallery designed by Architect Edgar Beaumont Jarvis (1864-1948) in the Beaux Arts style constructed in 1902. After 1905 it was known as The Graphic Arts and Photography Building. It was demolished in 1955. To the right is Dairy Building designed by Architect George William Gouinlock (1861-1932) constructed in 1903. On the right is the Manufacturers and Liberal Arts Building designed by Gouinlock constructed in 1902. The Women's Building was added to the original building in 1908. It was destroyed by fire in 1961 and replaced by the Better Living Centre designed by the architectural firm of Marani, Morris \& Allan (1959-1964) in 1962. In the distance is the second Grandstand constructed in 1895.

Alternate Number: AG0.98656 


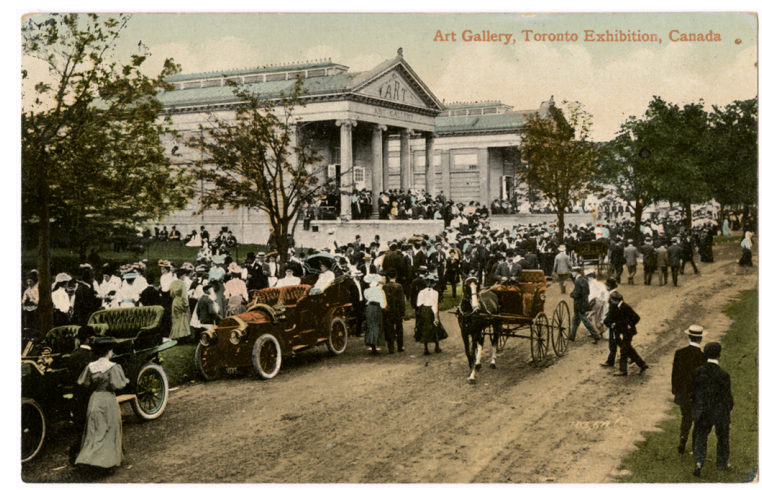

Recto

AGO Accession Number: 2011/192

Classification: Photography Collection Constituents:

Publisher: The Valentine \& Sons

Publishing Co. Ltd. Montreal and

Toronto

Photographer: Unknown

Constituents Note: The Valentine \& Sons

Publishing Co. Ltd. was founded in

Montreal and Toronto in 1903 and 1906

respectively. Operations were terminated in 1923.

Title: Art Gallery, Toronto Exhibition,

Canada

Title Note: Printed

Date(s) of Object: [between 1908 and 1911]

Date Notes: The card is postmarked

December 6, 1911 and was printed after

Valentine \& Sons began to use the

'FAMOUS THROUGHOUT THE WORLD'

trademark in 1908.

Object Name: Postcard

Medium: Letterpress halftone

Dimensions:

Image: $8.8 \times 13.7 \mathrm{~cm}, 3.46 \times 5.39$ in

Sheet: $8.8 \times 13.7 \mathrm{~cm}, 3.46 \times 5.39$ in

Geography:

Place Created: Great Britain

Place Depicted: A view of the CNE Art

Gallery looking east

Mark(s): recto: titled, [no.] 103,671 JV

[circled] l.r.; verso: publisher imprint, trademark, post template

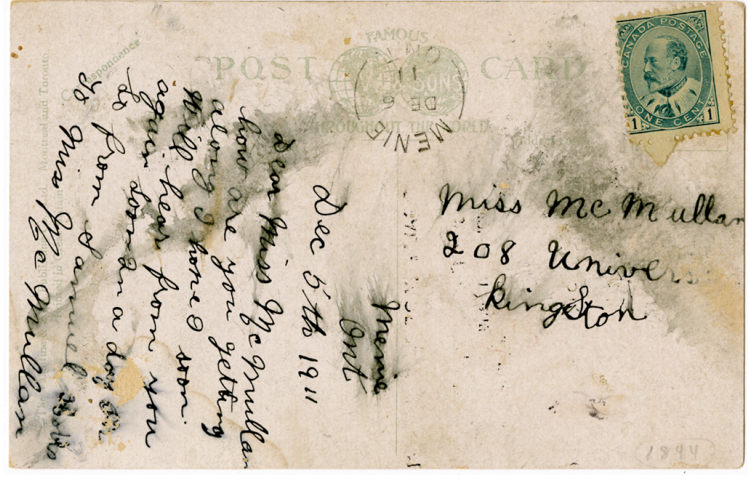

Verso

Inscriptions: verso: in ink: Menie Ont

Dec $5^{\text {th }} 1911$ Dear Miss McMullen how are you getting along I hope I soon will hear from you again Miss McMullen 208 Univers (?) Kingston; in graphite: [no.] 1894 [circled] l.r.

Notes: Designed by Architect George William Gouinlock (1861-1932) the Art Gallery was constructed in the Beaux Arts style in 1905 and demolished in 1972 Alternate Number: AG0.98657 


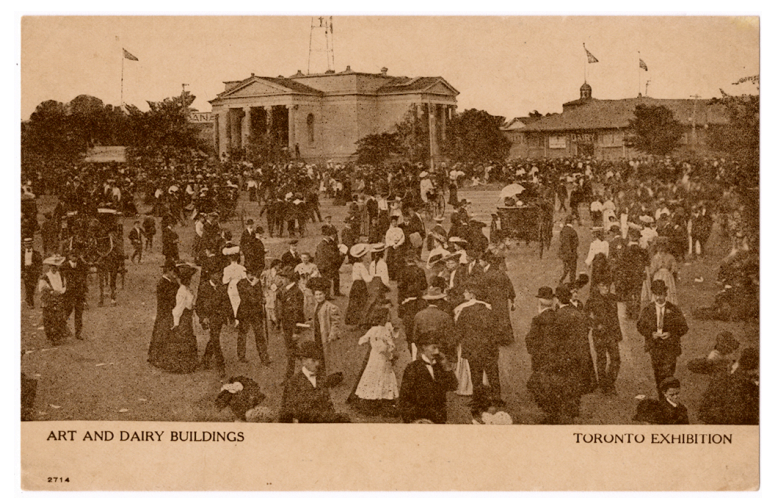

Recto

AGO Accession Number: 2011/193

Classification: Photography Collection

Constituents:

Publisher: Warwick Bro's \& Rutter, Limited, Printers, Toronto

Photographer: Unknown

Constituents Note: Warwick Bro's \&

Rutter published postcards between 1903 and 1912

Title: Art and Dairy Buildings - Toronto

Exhibition

Title Note: Printed

Date(s) of Object: [between 1903 and

$1912\}$

Date Notes: Warwick Bro's \& Rutter

commenced publishing postcards in 1903 and the Toronto Exhibition was renamed the Canadian National Exhibition in 1912.

Object Name: Postcard

Medium: Offset lithograph

Dimensions:

Image: $7.5 \times 13.7 \mathrm{~cm}, 2.95 \times 5.39$ in

Sheet: $8.8 \times 13.7 \mathrm{~cm}, 3.46 \times 5.39$ in

Geography:

Place Created: Toronto, Ontario

Place Depicted: A view of the grounds

of the Canadian National Exhibition

looking east towards the Art Gallery and

Dairy Building

Mark(s): recto: titled, [no.] 2714 l.l.;

verso: publishers imprint, post template

Inscriptions: verso: in graphite: [no.]

2627 [circled] 1.l.

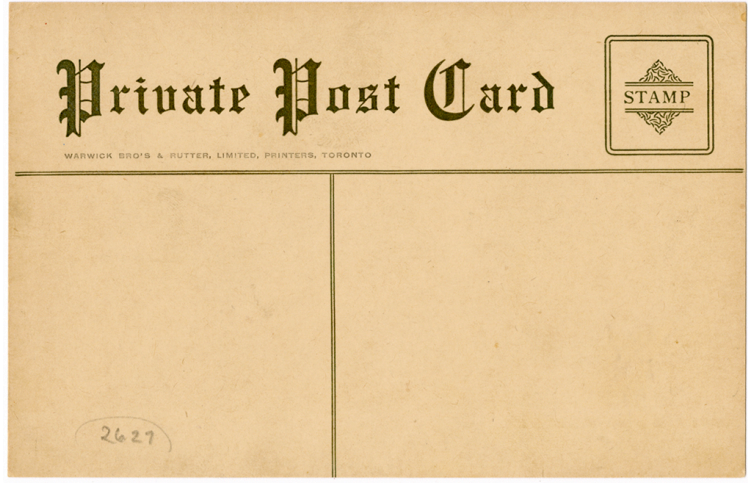

Verso

Notes: In the distance left of centre is the Art Gallery Designed by Architect Edgar Beaumont Jarvis (1864-1948) in the Beaux Arts style constructed in 1902. After 1905 it was known as The Graphic Arts and Photography Building. It was demolished in 1955. To the right of the Art Gallery is the Dairy Building designed by Architect George William Gouinlock (1861-1932) constructed in 1903.

Alternate Number: AG0.98658 


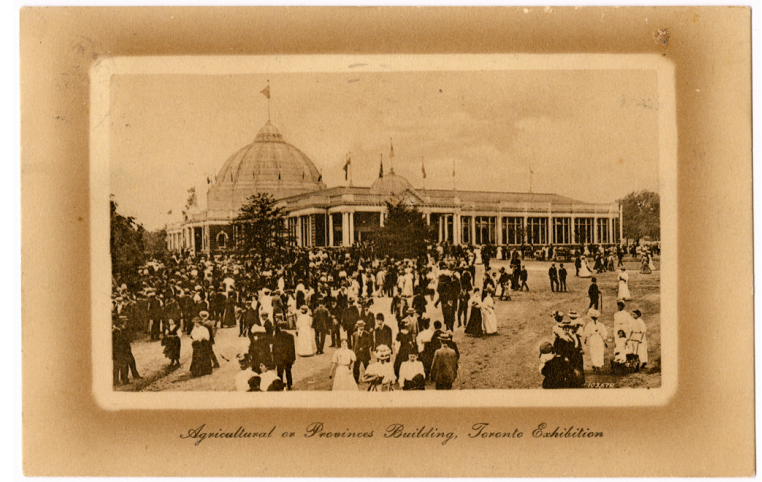

Recto

AGO Accession Number: 2011/194

Classification: Photography Collection

Constituents:

Publisher: The Valentine \& Sons

Publishing Co. Ltd. Montreal and

Toronto

Photographer: Unknown

Constituents Note: The Valentine \& Sons

Publishing Co. Ltd. was founded in

Montreal and Toronto in 1903 and 1906

respectively. Operations were terminated in 1923.

Title: Agricultural and Provinces

Buildings, Toronto Exhibition

Title Note: Printed

Date(s) of Object: [between 1903 and 1908\}

Date Notes: The card is postmarked

August 8, 1911 and was printed prior to

when the Valentine \& Sons began to use

the 'FAMOUS THROUGHOUT THE

WORLD' trademark in 1908.

Object Name: Postcard

Medium: Collotype

Dimensions:

Image: $6.0 \times 10.4 \mathrm{~cm}, 2.39 \times 4.09 \mathrm{in}$

Sheet: $9.0 \times 13.9 \mathrm{~cm}, 3.54 \times 5.47$ in

Geography:

Place Created: Great Britain

Place Depicted: A view of the grounds of the Canadian National Exhibition looking west towards the Horticultural Building

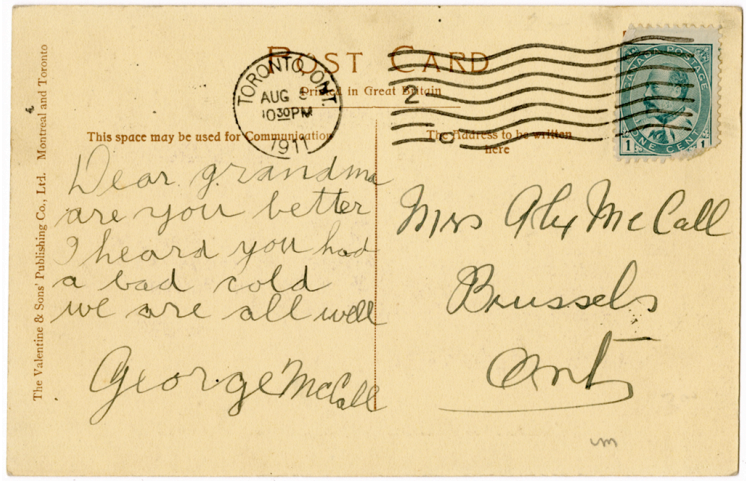

Verso

Mark(s): recto: titled, [no.] 103,672 l.r.; verso: publisher imprint, post template Inscriptions: verso: in ink: Dear Grandma are you better I heard you had a bad cold we are all well George McCall Mrs Aby McCall Brussels Ont

Notes: In the distance is the Horticultural Building designed by Architect George William Gouinlock (1861-1932) and constructed in 1906-07 and restored in 1981.

Alternate Number: AG0.98659 


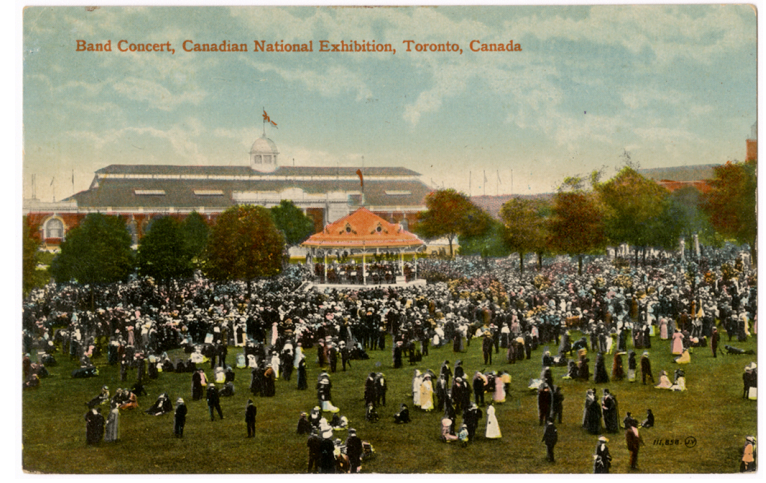

Recto

AGO Accession Number: 2011/195

AGO Accession Number:

Classification: Photography Collection

Publisher: The Valentine \& Sons

Publishing Co. Ltd. Montreal and

Toronto

Photographer: Unknown

Constituents Note: The Valentine \& Sons

Publishing Co. Ltd. was founded in

Montreal and Toronto in 1903 and 1906

respectively. Operations were terminated in 1923

Title: Band Concert, Canadian National

Exhibition, Toronto, Canada

Title Note: Printed

Date(s) of Object: [between 1908 and 1914]

Date Notes: The card is postmarked

September 9, 1914 and was printed after

Valentine \& Sons began to use the

'FAMOUS THROUGHOUT THE WORLD'

trademark in 1908.

Object Name: Postcard

Medium: Letterpress halftone

Dimensions:

Image: $8.7 \times 13.7 \mathrm{~cm}, 3.43 \times 5.39$ in

Sheet: $8.7 \times 13.7 \mathrm{~cm}, 3.43 \times 5.39$ in

Geography:

Place Created: Great Britain

Place Depicted: A view of the grounds

of the Canadian National Exhibition

looking west toward Lake Ontario

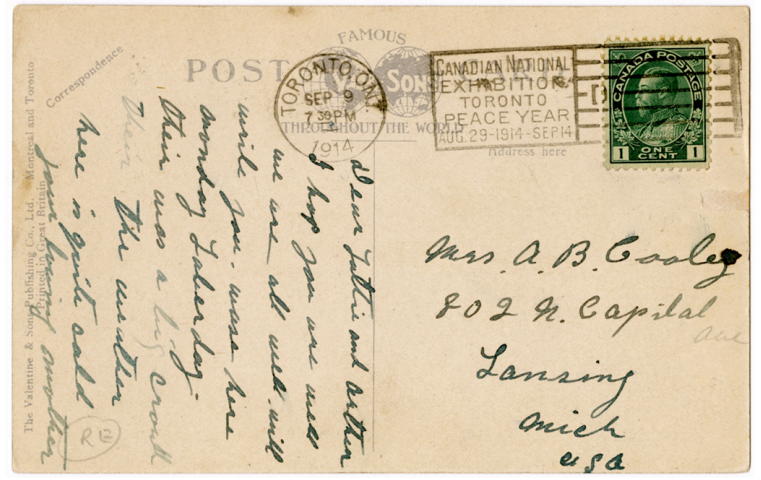

Verso

Mark(s): recto: titled, [no.] 111,858 JV [circled] l.r.; verso: publisher imprint, trademark, post template

Inscriptions: verso: in ink: Dear Hattie and Arthur I hope you are well we are all well will write you. Wase (?) here Monday Labor day their (sic) was a big crowd their (sic) the weather her is quite cold your loving mother Mrs. A. B. Cooley 202 N. Capital Lansing Mich U S A; in graphite: Ave l.r.; RE [circled] 1.l.

Notes: In the distance on the left is the Transportation Building designed by Architect George William Gouinlock (1861-1932) constructed in 1909 and destroyed by fire in 1974. The site is now occupied by Bandshell Park. In the distance on the right is the Dominion and Provincial Government Building designed by Gouinlock constructed in the Beaux Arts style in 1912. The building presently houses the dinner theatre Medieval Times Dinner and Tournament.

Alternate Number: AG0.98660 


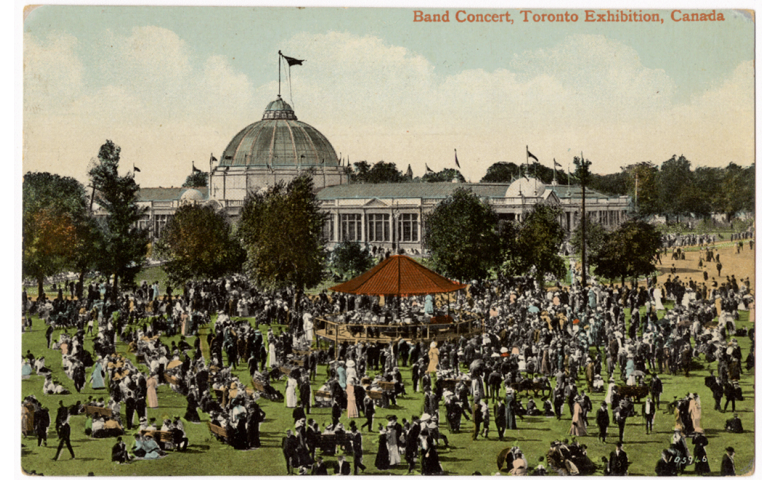

Recto

AGO Accession Number: 2011/196

Classification: Photography Collection

Constituents:

Publisher: The Valentine \& Sons

Publishing Co. Ltd. Montreal and

Toronto

Photographer: Unknown

Constituents Note: The Valentine \& Sons

Publishing Co. Ltd. was founded in

Montreal and Toronto in 1903 and 1906

respectively. Operations were terminated in 1923.

Title: Band Concert, Toronto Exhibition,

Canada

Title Note: Printed

Date(s) of Object: [between 1908 and

1911]

Date Notes: The card is postmarked

September 2, 1911 and was printed after

Valentine \& Sons began to use the

'FAMOUS THROUGHOUT THE WORLD'

trademark in 1908.

Object Name: Postcard

Medium: Letterpress halftone

Dimensions:

Image: $8.6 \times 13.3 \mathrm{~cm}, 3.39 \times 5.24 \mathrm{in}$

Sheet: $8.6 \times 13.3 \mathrm{~cm}, 3.39 \times 5.24$ in

Geography:

Place Created: Great Britain

Place Depicted: A view of the grounds

of the Canadian National Exhibition

looking southwest towards the

Horticultural Building

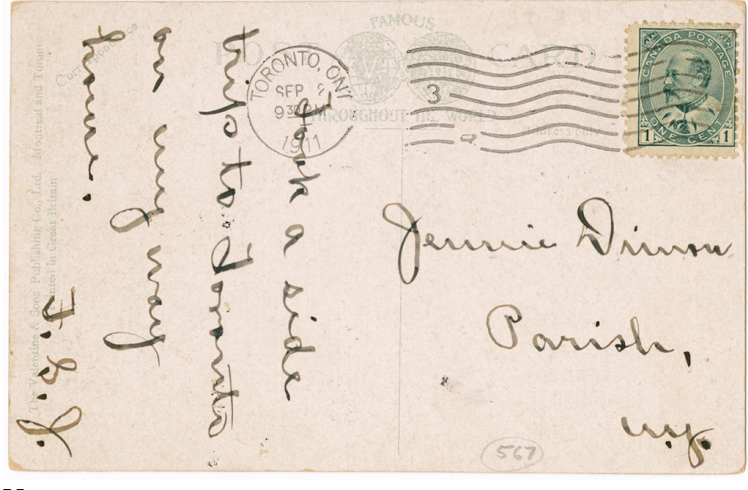

Verso

Mark(s): recto: titled, [no.] 105946 l.r.; verso: publisher imprint, trademark, post template

Inscriptions: verso: in ink: Took a side trip to Toronto on my way home F. G. J. Jennie Dinmore Parish N.Y.; in graphite: [no] 567 [circled] l.r.

Notes: Designed by Architect George William Gouinlock (1861-1932) the Horticultural Building constructed in 1906-07 was restored in 1981

Alternate Number: AG098661 


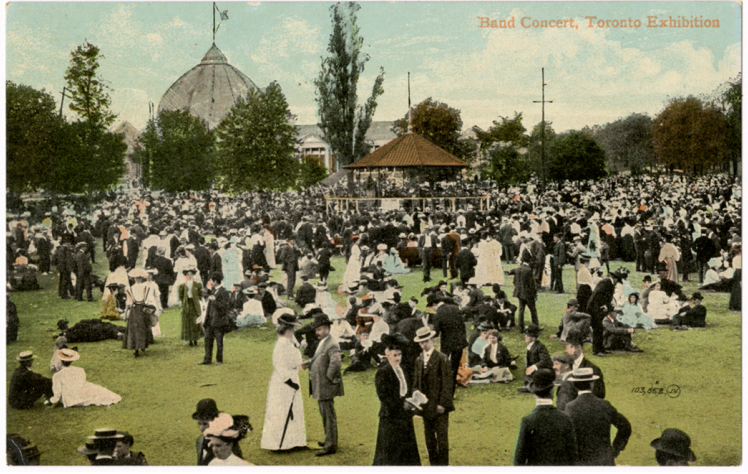

Recto

AG0 Accession Number: 2011/197

Classification: Photography Collection

Constituents:

Publisher: The Valentine \& Sons

Publishing Co. Ltd. Montreal and

Toronto

Photographer: Unknown

Constituents Note: The Valentine \& Sons

Publishing Co. Ltd. was founded in

Montreal and Toronto in 1903 and 1906

respectively. Operations were terminated in 1923.

Title: Band Concert, Toronto, Exhibition

Title Note: Printed

Date(s) of Object: [between 1903 and 1908]

Date Notes: This card was printed prior to when the Valentine \& Sons began to use the 'FAMOUS THROUGHOUT THE WORLD' trademark in 1908.

Object Name: Postcard

Medium: Letterpress halftone

Dimensions:

Image: $8.7 \times 13.7 \mathrm{~cm}, 3.43 \times 5.39$ in

Sheet: $8.7 \times 13.7 \mathrm{~cm}, 3.43 \times 5.39$ in

Geography:

Place Created: Great Britain

Place Depicted: A view of the grounds of the Canadian National Exhibition looking north towards the Horticultural Building

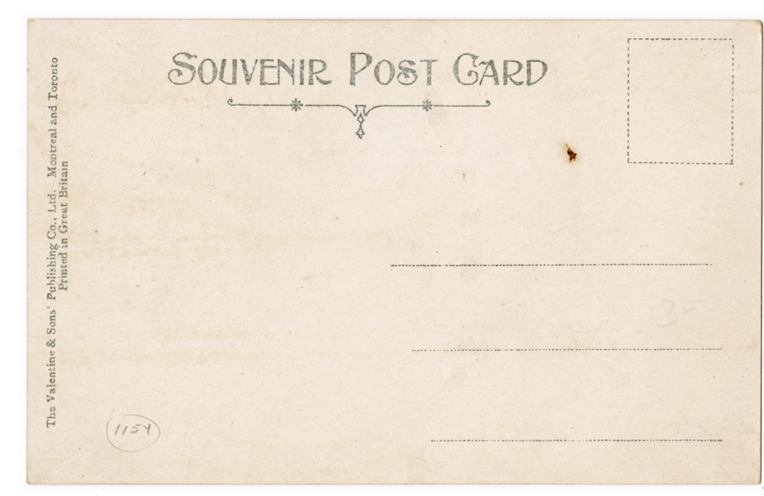

Verso

Mark(s): recto: titled, [no,] 130,658 JV [circled] l.r.; verso: publisher imprint, trademark 'Souvenir Post Card', post template

Inscriptions: verso: in graphite: [no.] 1154 [circled] 1.l.

Notes: Designed by Architect George William Gouinlock (1861-1932) the Horticultural Building constructed in 1906-07 was restored in 1981.

Alternate Number: AG0.98662 


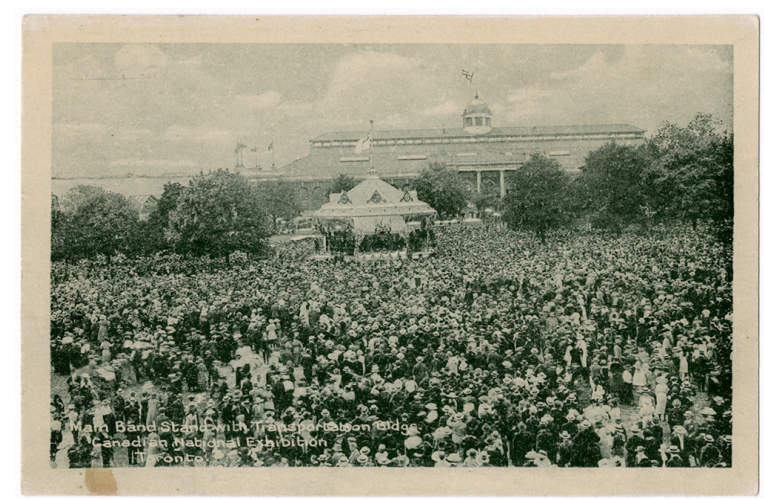

Recto

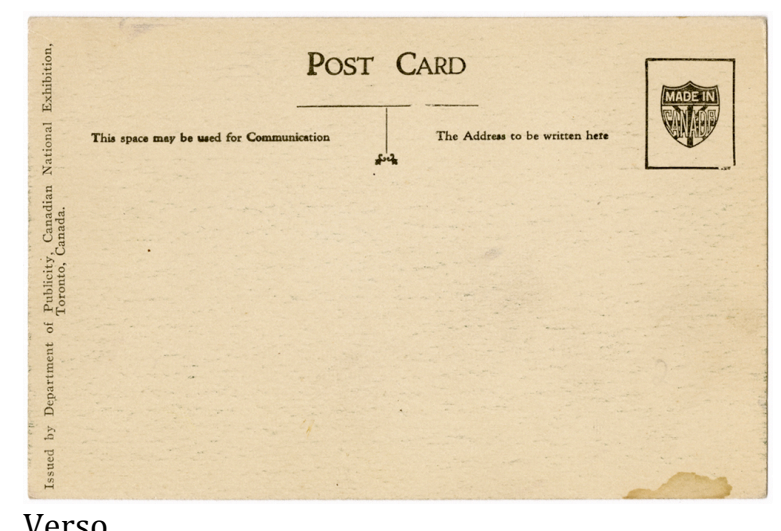

Verso

AG0 Accession Number: 2011/198

Classification: Photography Collection Constituents:

Publisher: Dept. of Publicity, Canadian

National Exhibition, Toronto, Canada

Photographer: Unknown

Constituents Note: None

Title: Main Band Stand with

Transportation Bldgs. Canadian National

Exhibition

Title Note: Printed

Date(s) of Object: [after 1915]

Date Notes: Divided postcards with white border were introduced in 1915.

Object Name: Postcard

Medium: Collotype

Dimensions:

Image: $7.9 \times 12.6 \mathrm{~cm}, 3.11 \times 4.96$ in

Sheet: $8.9 \times 13.7 \mathrm{~cm}, 3.50 \times 5.39$ in

Geography:

Place Created: Canada

Place Depicted: A view of the grounds of the Canadian National Exhibition looking southeast

Mark(s): recto: titled; verso: publisher imprint, trademark 'Made in Canada', post template

Inscriptions: None

Notes: Designed by Architect George

William Gouinlock (1861-1932) the

Transportation Building constructed in 1909 and destroyed by fire in 1974 . The site is now occupied by Bandshell Park.

Alternate Number: AGO.98663 


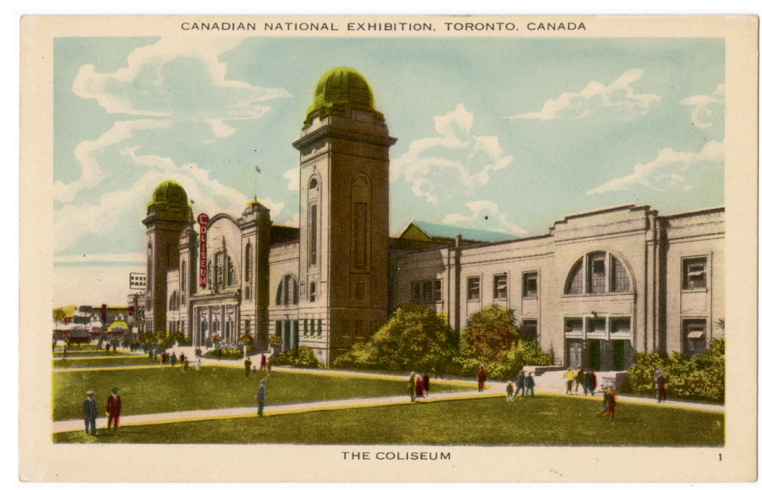

Recto

AGO Accession Number: 2011/199

Classification: Photography Collection

Constituents:

Publisher: Valentine-Black Co., Ltd., Toronto, Canada

Photographer: Unknown

Constituents Note: Valentine-Black Co., Ltd., maintained operations in Toronto from 1922 to 1933.

Title: Canadian National Exhibition, Toronto, Canada The Coliseum

Title Note: Printed

Date(s) of Object: [between 1922 and 1933]

Date Notes: Valentine-Black Co., Ltd., commenced and ceased operation between 1922 and 1933 respectively.

Object Name: Postcard

Medium: Offset lithograph

Dimensions:

Image: $7.7 \times 12.7 \mathrm{~cm}, 3.03 \times 5.00 \mathrm{in}$

Sheet: $8.9 \times 14.0 \mathrm{~cm}, 3.50 \times 5.51 \mathrm{in}$

\section{Geography:}

Place Created: unknown

Place Depicted: A view of the Colesium looking east

$\operatorname{Mark(s):~recto:~titled,~imprint~[no.]~} 1$ l.r.; verso: publisher imprint, trademark 'Bond Street Series', post template Inscriptions: verso: in graphite: MBC l.r.

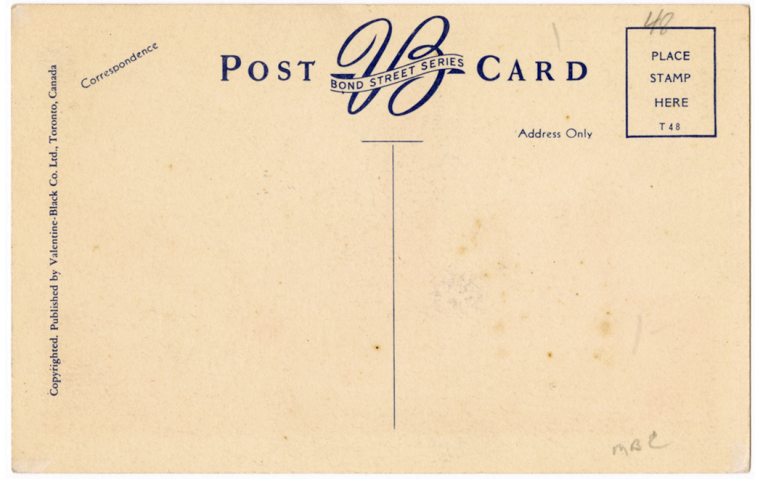

Verso

Notes: Designed by Architect George Frederick W. Price (1888-1982) the Coliseum also known as the Live Stock Arena constructed in 1921.

Alternate Number: AG0.98664 


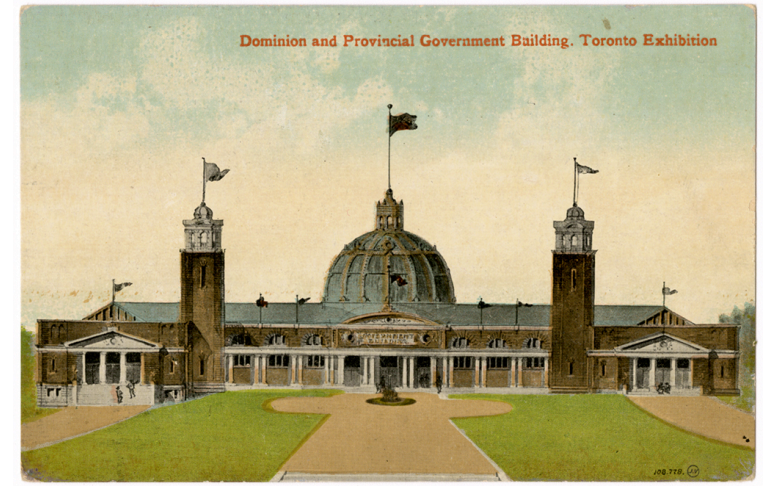

Recto

AGO Accession Number: 2011/200

Classification: Photography Collection

Constituents:

Publisher: The Valentine \& Sons

Publishing Co. Ltd. Montreal and

Toronto

Photographer: Unknown

Constituents Note: The Valentine \& Sons

Publishing Co. Ltd. was founded in

Montreal and Toronto in 1903 and 1906

respectively. Operations were terminated in 1923.

Title: Dominion and Provincial

Government Building, Toronto Exhibition

Title Note: Printed

Date(s) of Object: [between 1908 and 1912]

Date Notes: This card was printed after the Valentine \& Sons began to use the 'FAMOUS THROUGHOUT THE WORLD' trademark in 1908 and prior to the Toronto Exhibition being renamed the Canadian National Exhibition in 1912.

Object Name: Postcard

Medium: Letterpress halftone

Dimensions:

Image: $8.9 \times 13.6 \mathrm{~cm}, 3.50 \times 5.35 \mathrm{in}$

Sheet: $8.9 \times 13.6 \mathrm{~cm}, 3.50 \times 5.35 \mathrm{in}$

Geography:

Place Created: Great Britain

Place Depicted: A view of the

Dominion and Provincial

Government Building looking west.

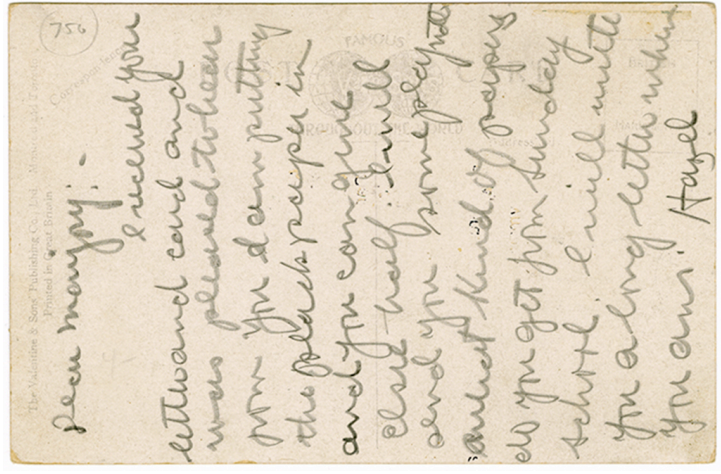

Verso

Mark(s): recto: titled, [no.] 108,778 JV [circled] l.r.; verso: publisher imprint, trademark, post template

Inscriptions: verso: in ink: Dear Marjory I received your letter and card and was pleased to hear from you I am putting the black paper in and you can give Elsie half. I will send you some play notes what kind of papers do you get from Sunday school. I will write a long letter when you ans. Hazel,; in graphite: [no.] 756 [circled] t.l. Notes: Designed by Architect George William Gouinlock (1861-1932) the Dominion and Provincial Government Building was constructed in the Beaux Arts style in 1912. The building presently houses the dinner theatre Medieval Times Dinner and Tournament.

Alternate Number: AG0.98665 


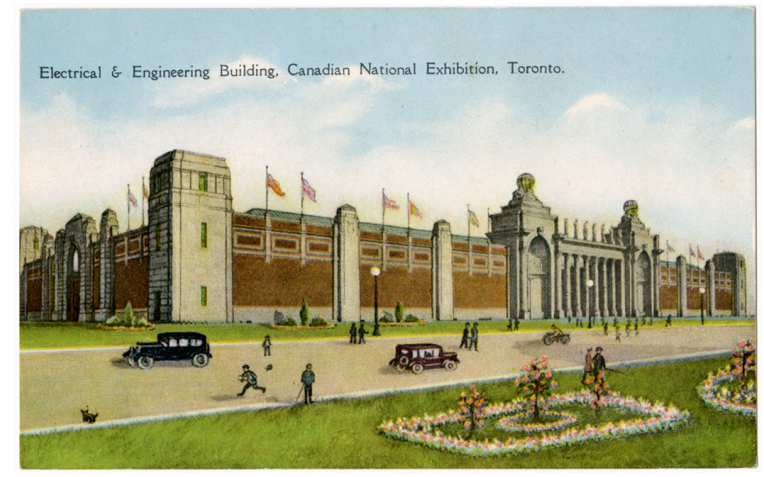

Recto

AGO Accession Number: 2011/201

Classification: Photography Collection

Constituents:

Publisher: Post Card \& Greeting Card Co. Ltd., Toronto

Photographer: Unknown

Constituents Note: The Post Card \& Greeting Cart Co. Ltd. maintained offices in Toronto from the 1920s and terminated operations in 1935.

Title: Electrical \& Engineering Building, Canadian National Exhibition

Title Note: Printed

Date(s) of Object: [between 1912 and 1935]

Date Notes: Toronto Industrial

Exhibition was renamed the Canadian

National Exhibition in 1912. The Post

Card \& Greeting Co. ceased operations in 1935.

Object Name: Postcard

Medium: Offset lithograph

Dimensions:

Image: $8.6 \times 13.7 \mathrm{~cm}, 3.39 \times 5.39$ in

Sheet: $8.6 \times 13.7 \mathrm{~cm}, 3.39 \times 5.39$ in

Geography:

Place Created: Canada

Place Depicted: A view of the Electrical and Engineering Building looking northeast

Mark(s): recto: titled; verso: publisher imprint, trademark 'Canada Series', post template

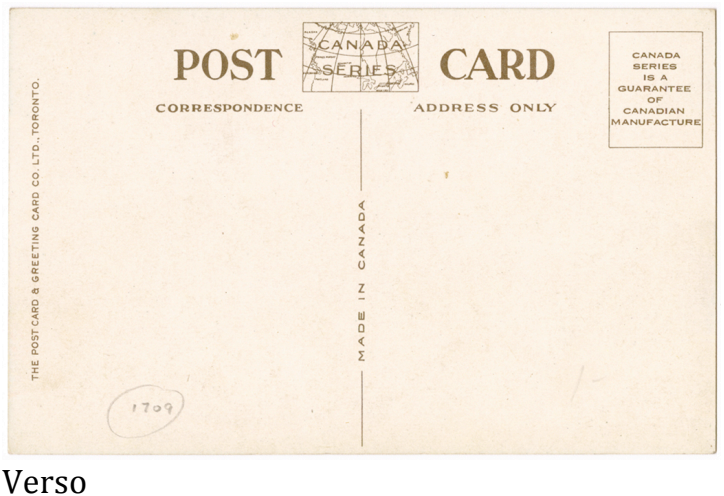

Inscriptions: verso: [no.] 1709 [circled] l.l.

Notes: Designed by Architects Alfred Hirschfelder Chapman (1879-1949) and James Morrow Oxley (1883-1957) the Electrical and Engineering Building was constructed in 1928-29 and demolished in the 1970s. The Direct Energy Centre now occupies the site.

Alternate Number: AGO.98666 


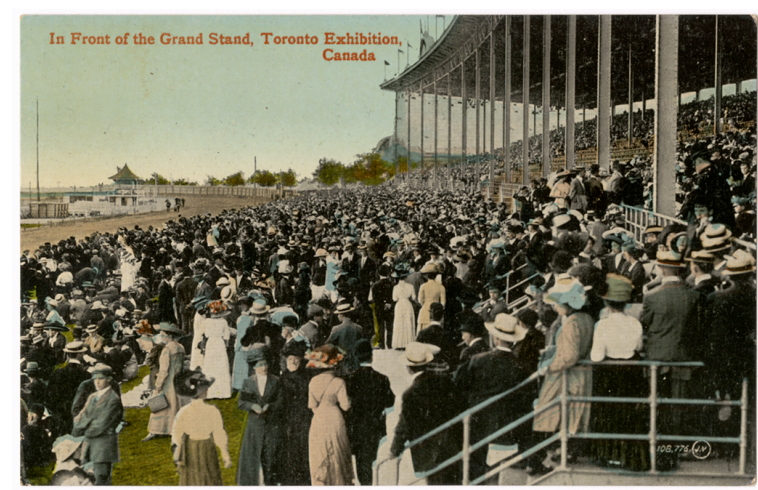

Recto

AGO Accession Number: 2011/202

Classification: Photography Collection

Constituents:

Publisher: The Valentine \& Sons

Publishing Co. Ltd. Montreal and

Toronto

Photographer: Unknown

Constituents Note: The Valentine \& Sons

Publishing Co. Ltd. was founded in

Montreal and Toronto in 1903 and 1906

respectively. Operations were terminated in 1923.

Title: In Front of the Grand Stand,

Toronto Exhibition, Canada

Title Note: Printed

Date(s) of Object: [between 1908 and 1912]

Date Notes: This card was printed after

Valentine \& Sons began to use the 'FAMOUS THROUGHOUT THE WORLD' trademark in 1908 and prior to the Toronto Exhibition being renamed the Canadian National Exhibition in 1912.

Object Name: Postcard

Medium: Letterpress halftone

Dimensions:

Image: $8.7 \times 13.7 \mathrm{~cm}, 3.43 \times 5.39$ in

Sheet: $8.7 \times 13.7 \mathrm{~cm}, 3.43 \times 5.39$ in

Geography:

Place Created: Great Britain

Place Depicted: An interior view of the Grandstand looking west

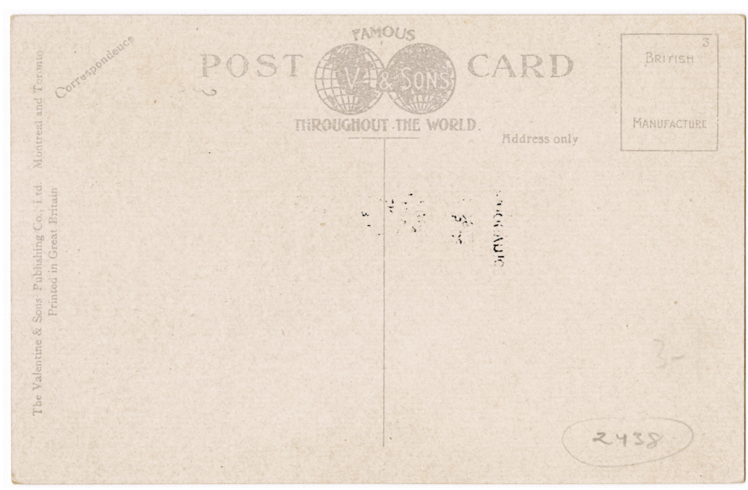

Verso

Mark(s): recto: titled, [no.] 108,776 JV [circled] l.r.; verso: publisher imprint, trademark, post template

Inscriptions: verso: in graphite: [no.] 2438 [circled] l.r.

Notes: Designed by Architect George William Gouinlock (1861-1932) the Grandstand constructed in 1906 had a capacity of 16,400 seats and was destroyed by fire in 1946 .

Alternate Number: AGO.98667 


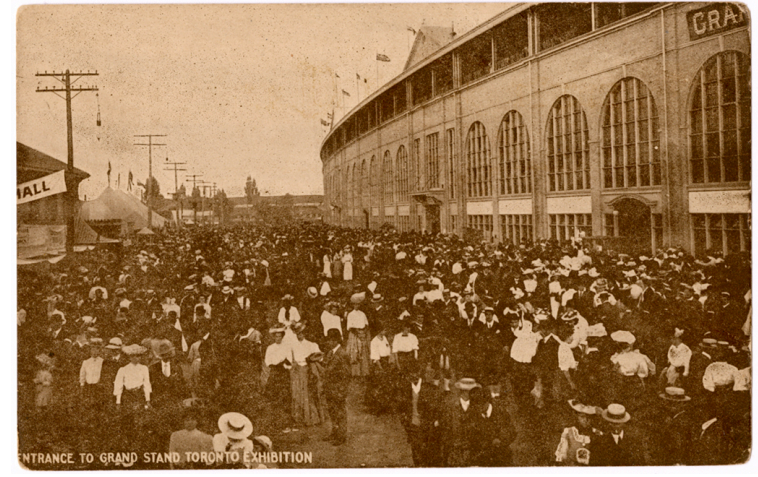

Recto

AG0 Accession Number: 2011/203

Classification: Photography Collection Constituents:

Publisher: Warwick Bro's \& Rutter, Limited, Printers, Toronto

Photographer: Unknown

Constituents Note: Warwick Bro's \&

Rutter, Limited maintained operations in Toronto from 1860 to 1972 and

published postcards between 1903 and

1912

Title: Entrance to Grand Stand Toronto

Exhibition

Title Note: Printed

Date(s) of Object: 1912

Date Notes: Toronto Industrial

Exhibition was renamed the Canadian

National Exhibition in 1912 and Warwick

Bro's \& Rutter published postcards

between 1903 and 1912.

Object Name: Postcard

Medium: Rotogravure

Dimensions:

Image: $8.8 \times 13.8 \mathrm{~cm}, 3.46 \times 5.43$ in

Sheet: $8.8 \times 13.8 \mathrm{~cm}, 3.46 \times 5.43 \mathrm{in}$

Geography:

Place Created: Toronto, Ontario

Place Depicted: A view of the exterior of the Grandstand looking east

Mark(s): recto: titled; verso: publisher imprint, post template, [no.] 5208 t.r.

Inscriptions: verso: in graphite: [no.]

2626 [circled] l.l.

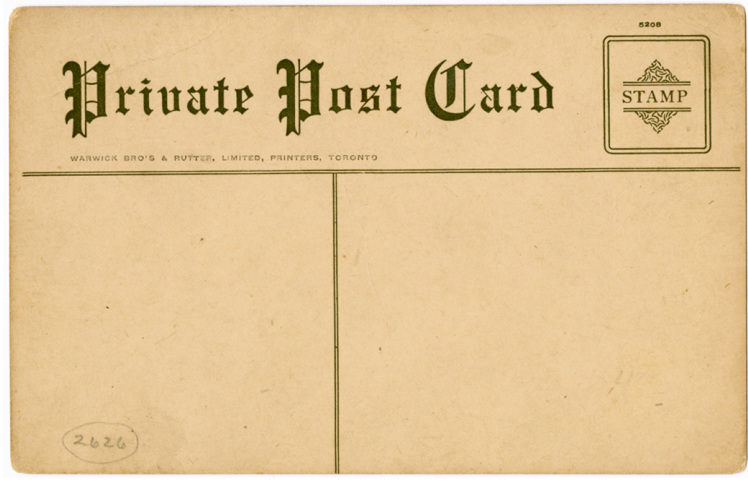

Verso

Notes: Designed by Architect George

William Gouinlock (1861-1932) the Grandstand constructed in 1906 had a capacity of 16,400 seats and was destroyed by fire in 1946 .

Alternate Number: AG0.98668 


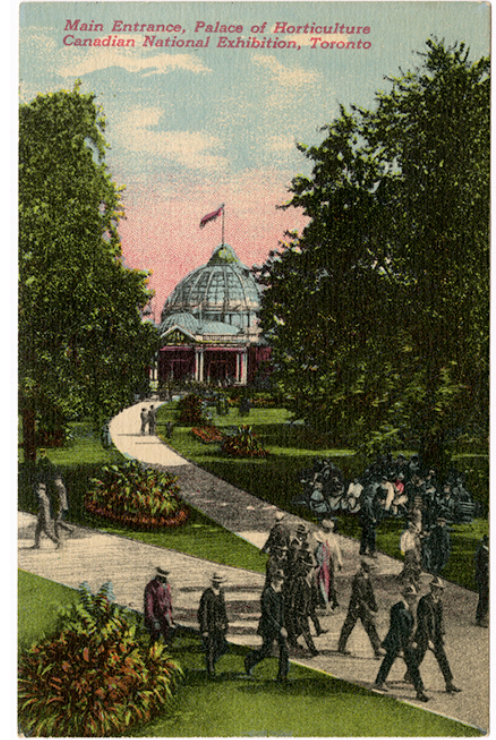

Recto

AGO Accession Number: 2011/204

Classification: Photography Collection Constituents:

Publisher: Southam Press Ltd., Toronto \& Montreal

Photographer: Unknown

Constituents Note:

Title: Main Entrance, Palace of

Horticulture, Canadian National

Exhibition

Title Note: Printed

Date(s) of Object: 1922

Date Notes: None

Object Name: Postcard

Medium: Offset lithograph

Dimensions:

Image: $13.9 \times 8.8 \mathrm{~cm}, 5.47 \times 3.46$ in

Sheet: $13.9 \times 8.8 \mathrm{~cm}, 5.47 \times 3.46$ in

Geography:

Place Created: Canada

Place Depicted: A view of the grounds of the Canadian National Exhibition looking west towards the Horticultural Building

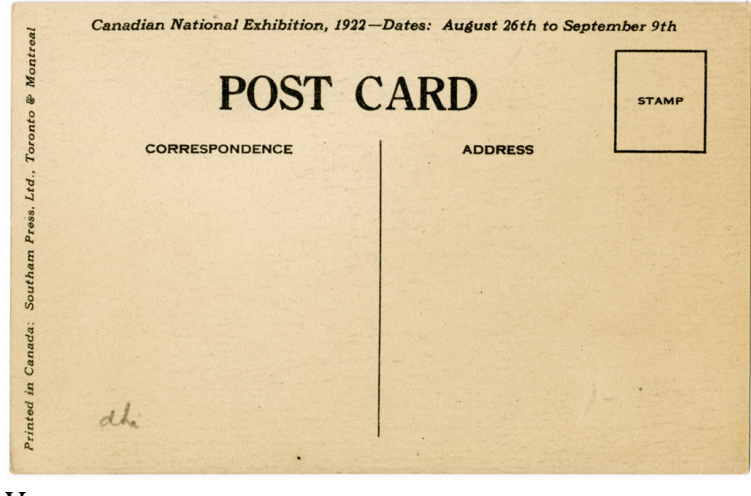

Verso

Mark(s): recto: titled; verso: publisher imprint, 'Canadian National Exhibition, 1922 - Dates: August 26 to September 9th, post template

Inscriptions: verso: in graphite: dh l.l. Notes: Designed by Architect George William Gouinlock (1861-1932) the Horticultural Building was constructed in 1906-07 and restored in 1981.

Alternate Number: AG0.98669 


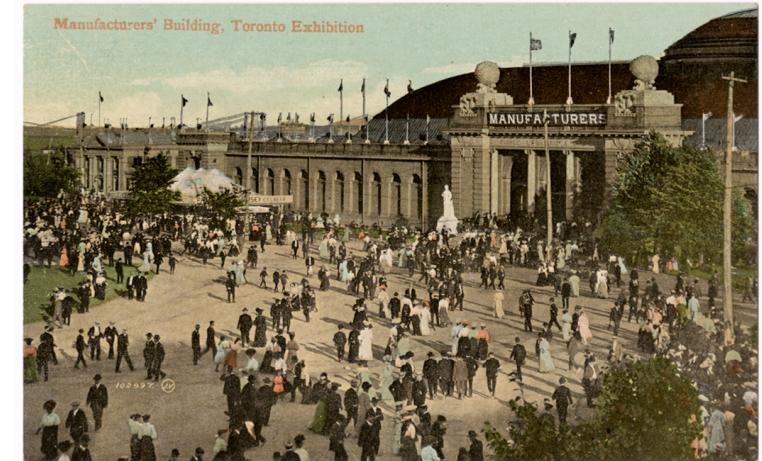

Recto

AGO Accession Number: 2011/205

Classification: Photography Collection Constituents:

Publisher: The Valentine \& Sons

Publishing Co. Ltd. Montreal and

Toronto

Photographer: Unknown

Constituents Note: The Valentine \& Sons

Publishing Co. Ltd. was founded in

Montreal and Toronto in 1903 and 1906

respectively. Operations were terminated in 1923.

Title: Manufacturers' Building, Toronto Exhibition

Title Note: Printed

Date(s) of Object: [between 1903 and 1908]

Date Notes: This card was printed prior to when Valentine \& Sons began to use the 'FAMOUS THROUGHOUT THE WORLD' trademark in 1908.

Object Name: Postcard

Medium: Letterpress halftone

Dimensions:

Image: $8.7 \times 13.9 \mathrm{~cm}, 3.43 \times 5.47$ in

Sheet: $8.7 \times 13.9 \mathrm{~cm}, 3.43 \times 5.47 \mathrm{in}$

\section{Geography:}

Place Created: Great Britain

Place Depicted: A view of the grounds of the Canadian National Exhibition looking southeast towards the Manufacturers and Liberal Arts Building

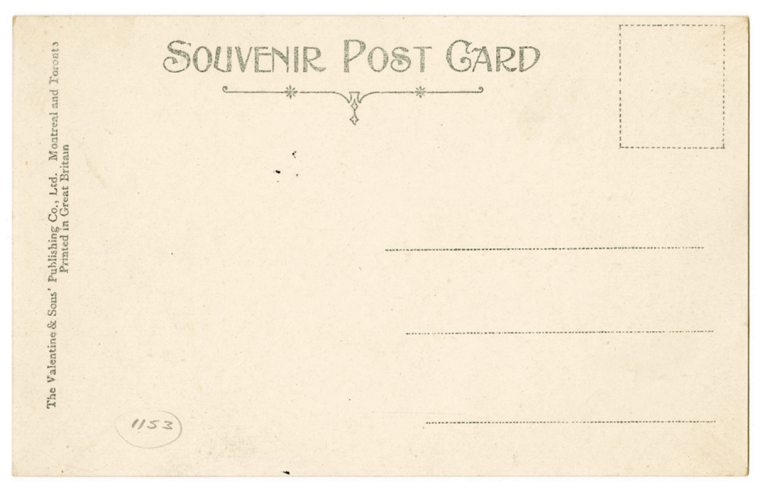

Verso

Mark(s): recto: titled, [no.] $102997 \mathrm{JV}$ [circled] 1.l.; verso: publisher imprint, trademark 'Souvenir Post Card', post template

Inscriptions: verso: in graphite: [no.] 1153 [circled] l.l.

Notes: Designed by Architect Gouinlock and constructed in 1902. The Women's Building was added to the original building in 1908. It was destroyed by fire in 1961 and replaced by the Better Living Centre designed by the architectural firm of Marani, Morris \& Allan (1959-1964) in 1962.

Alternate Number: AGO.98670 


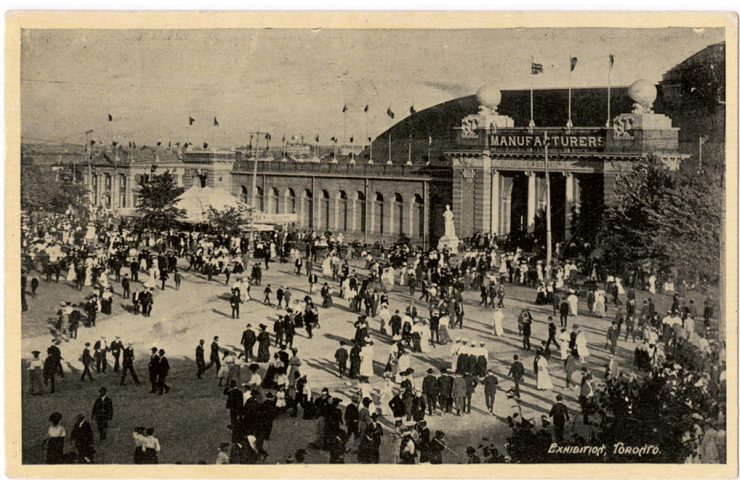

Recto

AGO Accession Number: 2011/206

Classification: Photography Collection Constituents:

Publisher: Henry Garner - Living

Picture Post Card Co. (H G L)

Photographer: Unknown

Constituents Note: The Henry Garner -

Living Picture Postcard Co. was located in Leicester England and produced postcards depicting scenes of Toronto.

Title: Exhibition Toronto

Title Note: Printed

Date(s) of Object: 1908

Date Notes: The card is postmarked

September 1, 1908.

Object Name: Postcard

Medium: Letterpress halftone

Dimensions:

Image: $8.3 \times 13.3 \mathrm{~cm}, 3.27 \times 5.24$ in

Sheet: $8.9 \times 13.9 \mathrm{~cm}, 3.50 \times 5.47$ in

Geography:

Place Created: Unknown

Place Depicted: A view of the grounds

looking southeast towards the

Manufacturers and Liberal Arts Building

Mark(s): recto: titled; verso: publisher imprint, trademark 'H G L ', post template Inscriptions: verso: in ink: Dear Jessie Have not made any change in my plans to leave Toronto at 8 a. m. Monday paper says the train gets into Barrie about eleven. You will know. Loving auntie Miss Jessie Hill Allandale Ontario, in graphite: [no.] 2206 l.r.

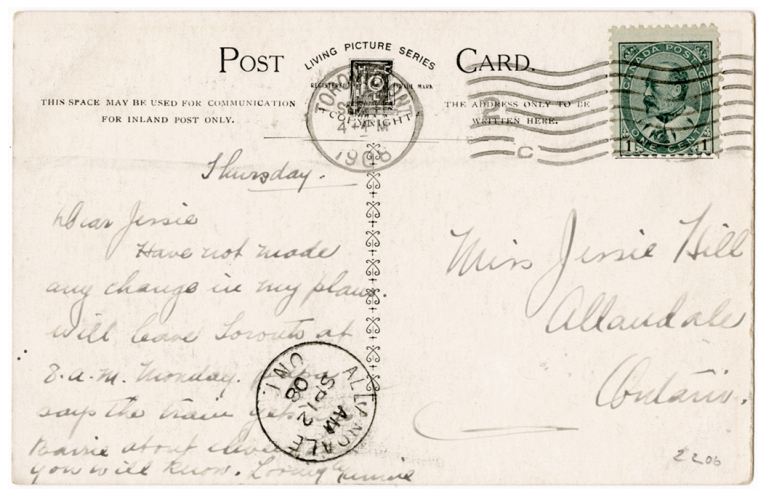

Verso

Notes: Designed by Architect Gouinlock and constructed in 1902. The Women's Building was added to the original building in 1908. It was destroyed by fire in 1961 and replaced by the Better Living Centre designed by the architectural firm of Marani, Morris \& Allan (1959-1964) in 1962.

Alternate Number: AG0.98671 


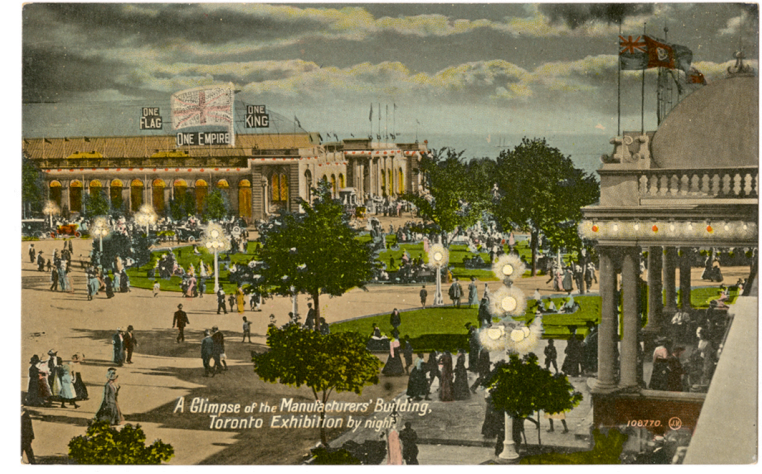

Recto

AGO Accession Number: 2011/207

Classification: Photography Collection

\section{Constituents:}

Publisher: The Valentine \& Sons

Publishing Co. Ltd. Montreal and

Toronto

Photographer: Unknown

Constituents Note: The Valentine \& Sons

Publishing Co. Ltd. was founded in

Montreal and Toronto in 1903 and 1906

respectively. Operations were terminated in 1923.

Title: A Glimpse of the Manufacturers' Building, Toronto Exhibition by night

Title Note: Printed

Date(s) of Object: [between 1908 and 1912]

Date Notes: This card was printed after Valentine \& Sons began to use the 'FAMOUS THROUGHOUT THE WORLD' trademark in 1908 and the Toronto Industrial Exhibition being renamed the Canadian National Exhibition in 1912.

Object Name: Postcard

Medium: Letterpress halftone

Dimensions:

Image: $8.7 \times 13.9 \mathrm{~cm}, 3.43 \times 5.47 \mathrm{in}$

Sheet: $8.7 \times 13.9 \mathrm{~cm}, 3.43 \times 5.47 \mathrm{in}$

\section{Geography:}

Place Created: Great Britain

Place Depicted: A view of the grounds of the Canadian National Exhibition looking south towards the Manufacturers and Liberal Arts Building and Lake Ontario

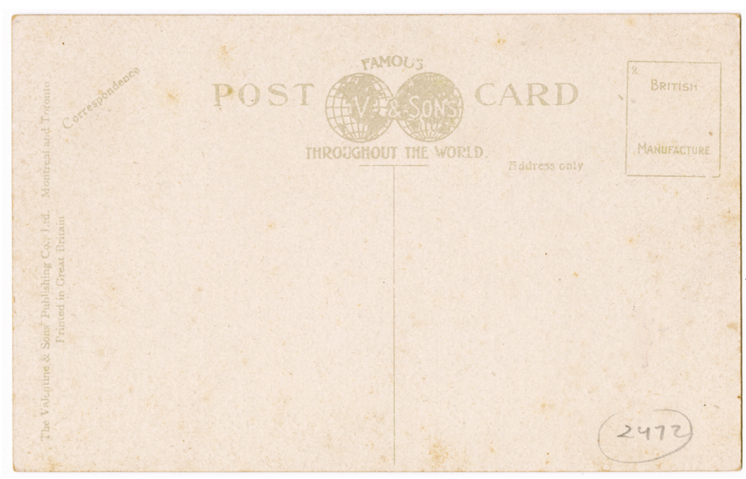

Verso

Mark(s): recto: titled, [no.] 108,770 JV [circled] l.r.; verso: publisher imprint, trademark, post template Inscriptions: verso: in graphite: [no.] 2472 [circled] l.r.

Notes: In the distance to the left is the Manufacturers and Liberal Arts Building designed by Architect Gouinlock constructed in 1902. The Women's Building was added to the original building in 1908. It was destroyed by fire in 1961 and replaced by the Better Living Centre designed by the architectural firm of Marani, Morris \& Allan (1959-1964) in 1962. To the right is the Horticultural Building designed by Gouinlock the Horticultural Building constructed in 1906-07 was restored in 1981.

Alternate Number: AGO.98672 


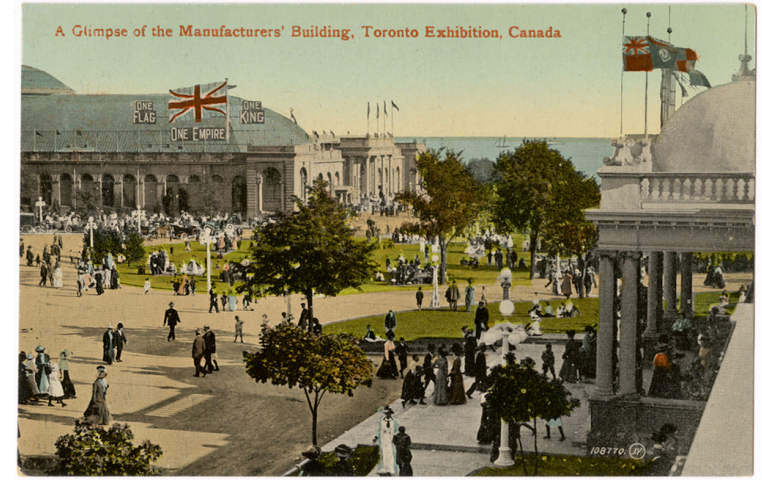

Recto

AGO Accession Number: 2011/208

Classification: Photography Collection

Constituents:

Publisher: The Valentine \& Sons

Publishing Co. Ltd. Montreal and

Toronto

Photographer: Unknown

Constituents Note: The Valentine \& Sons

Publishing Co. Ltd. was founded in

Montreal and Toronto in 1903 and 1906

respectively. Operations were terminated in 1923.

Title: A Glimpse of the Manufacturers' Building, Toronto Exhibition, Canada

Title Note: Printed

Date(s) of Object: [between 1908 and 1912]

Date Notes: This card was printed after Valentine \& Sons began to use the 'FAMOUS THROUGHOUT THE WORLD' trademark in 1908 and prior to the Toronto Industrial Exhibition being renamed the Canadian National Exhibition in 1912.

Object Name: Postcard

Medium: Letterpress halftone

Dimensions:

Image: $8.7 \times 13.6 \mathrm{~cm}, 3.43 \times 5.39$ in

Sheet: $8.7 \times 13.6 \mathrm{~cm}, 3.43 \times 5.39$ in

Geography:

Place Created: Great Britain

Place Depicted: A view of the grounds of the Canadian National Exhibition looking south towards the

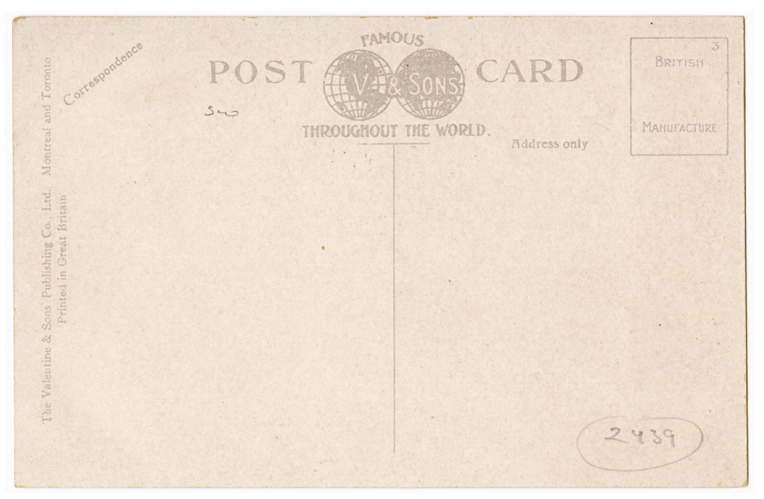

Verso

Manufacturers and Liberal Arts Building and Lake Ontario

Mark(s): recto: titled, [no.] 108,770 JV [circled] l.r.; verso: publisher imprint, trademark, post template

Inscriptions: verso: in graphite: [no.] 2439 [circled] l.r.

Notes: In the distance to the left is the Manufacturers and Liberal Arts Building designed by Architect Gouinlock and constructed in 1902. The Women's Building was added to the original building in 1908. It was destroyed by fire in 1961 and replaced by the Better Living Centre designed by the architectural firm of Marani, Morris \& Allan (1959-1964) in 1962. To the right is the Horticultural Building designed by Gouinlock the Horticultural Building constructed in 1906-07 and restored in 1981.

Alternate Number: AG0.98673 


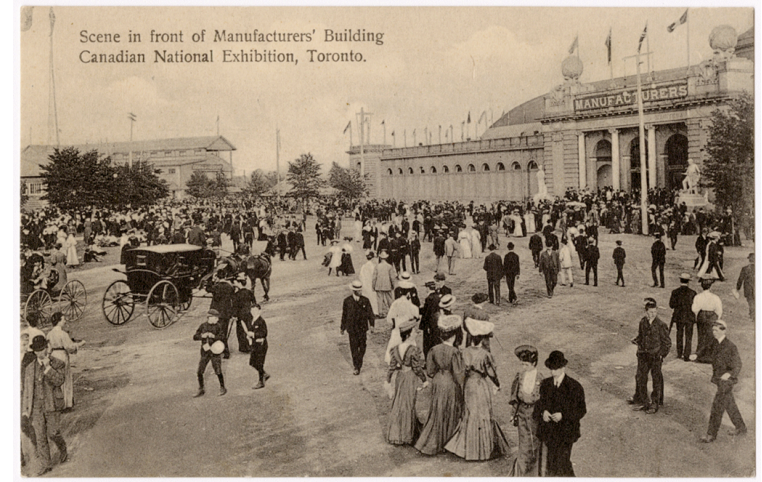

Recto

AGO Accession Number: 2011/209

Classification: Photography Collection

Constituents:

Publisher: Walter M. Lowney Co. of

Canada, Limited

Photographer: Unknown

Constituents Note: The Walter M.

Lowney Company, an American candy manufacturer was founded in 1883 in Boston, Massachusetts. In 1905 a candy factory was built in Montreal in 1905, and offices were established in Toronto, Winnipeg, Calgary, and Vancouver.

Title: Scene in front of Manufacturers' Building Canadian National Exhibition, Toronto

Title Note: Printed

Date(s) of Object: [after 1912]

Date Notes: The Toronto Industrial

Exhibition was renamed the Canadian

National Exhibition in 1912.

Object Name: Postcard

Medium: Collotype

Dimensions:

Image: $8.8 \times 13.7 \mathrm{~cm}, 3.46 \times 5.39$ in

Sheet: $8.8 \times 13.7 \mathrm{~cm}, 3.46 \times 5.39$ in

\section{Geography:}

Place Created: Germany

Place Depicted: A view of the grounds of the Canadian National Exhibition looking east toward the Grandstand and the Manufacturers and Liberal Arts Building

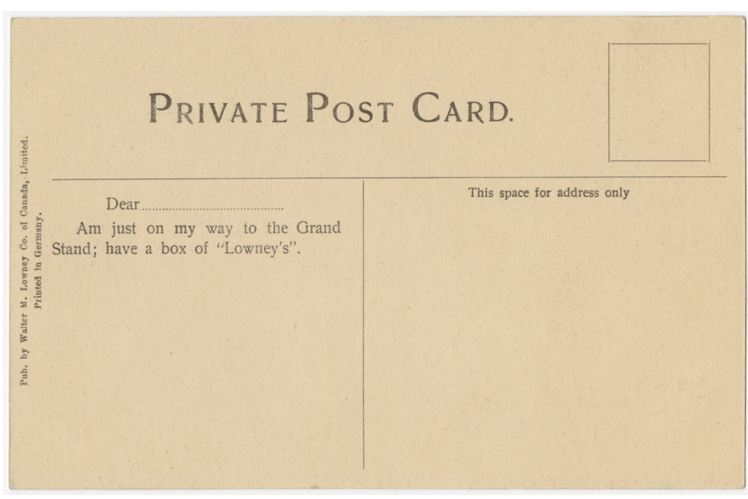

Verso

Mark(s): recto: titled; verso: publisher imprint, 'Dear...Am just on my way to the Grand Stand; have a box of "Lowney's".' Inscriptions: None

Notes: In the distance to the left is the Grandstand constructed in 1895. To the right is the Manufacturers and Liberal Arts Building designed by Architect Gouinlock and constructed in 1902. The Women's Building was added to the original building in 1908. It was destroyed by fire in 1961 and replaced by the Better Living Centre designed by the architectural firm of Marani, Morris \& Allan (1959-1964) in 1962.

Alternate Number: AG0.98674 


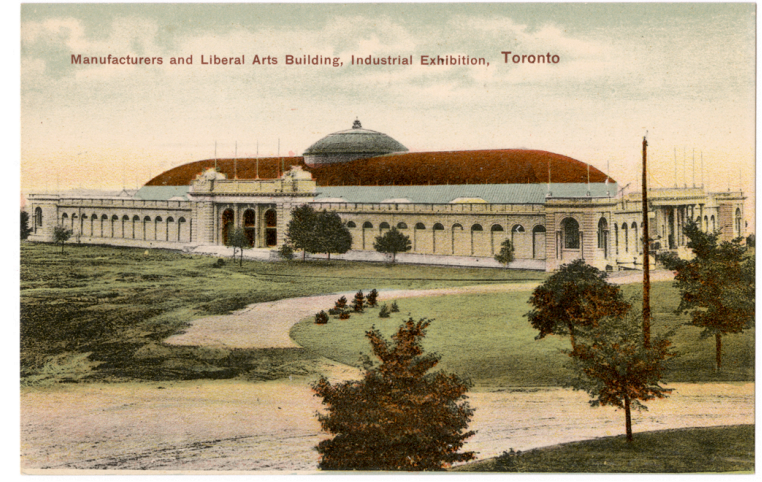

Recto

AGO Accession Number: 2011/210

Classification: Photography Collection

Constituents:

Publisher: Unknown

Photographer: Unknown

Constituents Note: None

Title: Manufacturers and Liberal Arts

Building, Industrial Exhibition, Toronto

Title Note: Printed

Date(s) of Object: [between 1903 and 1912]

Date Notes: Postal Regulations in Canada allowed for divided postcards in 1903 and the Industrial Exhibition was renamed the Canadian National Exhibition in 1912.

Previous entry early 20th Century

Object Name: Postcard

Medium: Collotype

Dimensions:

Image: $8.8 \times 13.7 \mathrm{~cm}, 3.46 \times 5.39 \mathrm{in}$

Sheet: $8.8 \times 13.7 \mathrm{~cm}, 3.46 \times 5.39$ in

\section{Geography:}

Place Created: unknown

Place Depicted: A view of the

Manufacturers and Liberal Arts Building looking southeast

Mark(s): recto: titled; verso: [no.] 1314

l.l., post template

Inscriptions: None

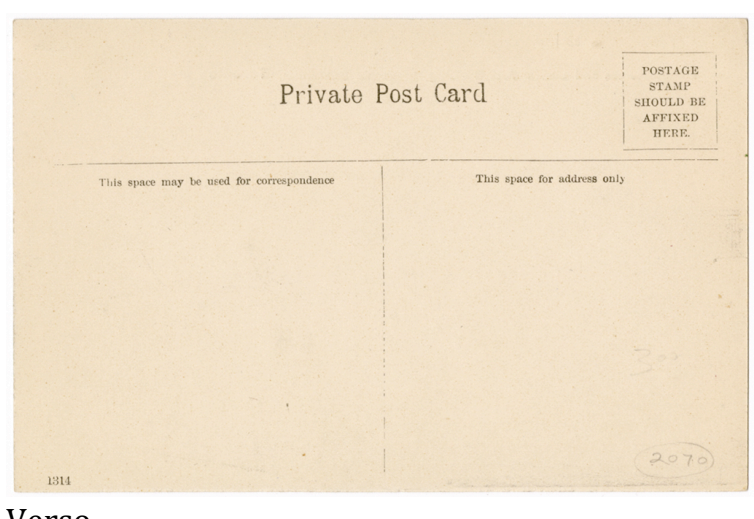

Verso

Notes: Designed by Architect George William Gouinlock (1861-1932) the Manufacturers and Liberal Arts Building was constructed in 1902. The Women's Building was added to the original building in 1908. The building was destroyed by fire in 1961 and was replaced by the Better Living Centre. Alternate Number: AG0.98675 


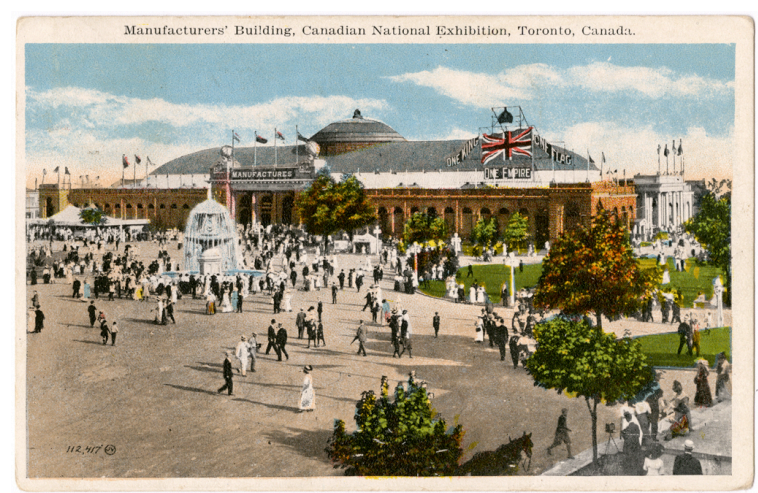

Recto

AGO Accession Number: 2011/211 Classification: Photography Collection Constituents:

Publisher: The Valentine \& Sons United Publishing Co. Ltd. Toronto and Winnipeg

Photographer: Unknown Constituents Note: The Valentine \& Sons Publishing Co. Ltd. was founded in Montreal and Toronto in 1903 and 1906 respectively. Operations were terminated in 1923.

Title: Manufacturers' Building, Canadian National Exhibition, Toronto, Canada Title Note: Printed Date(s) of Object: [between 1915 and 1919]

Date Notes: The card is postmarked September 9, 1919. White bordered cards were introduced in 1915.

Object Name: Postcard

Medium: Letterpress halftone Dimensions:

Image: $8.1 \times 13.1 \mathrm{~cm}, 3.19 \times 5.16$ in Sheet: $8.9 \times 13.8 \mathrm{~cm}, 3.50 \times 5.43 \mathrm{in}$

\section{Geography:}

Place Created: printed in the U. S. A.

Place Depicted: A view of the grounds of the Canadian National Exhibition looking southeast towards the Manufacturers and Liberal Arts Building

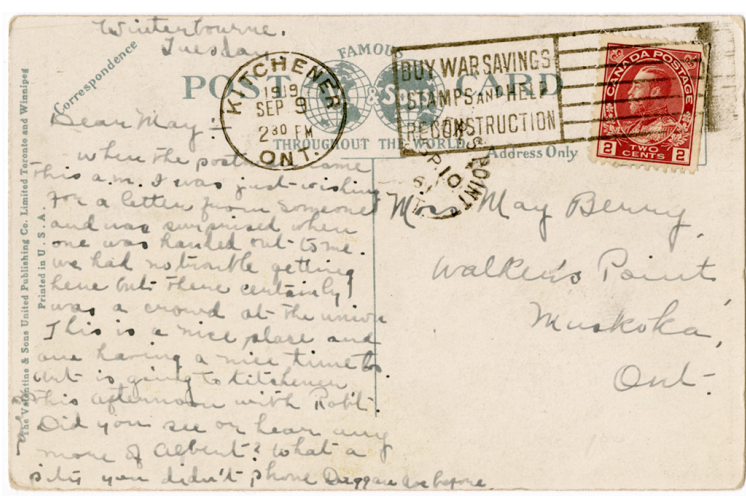

Verso

Mark(s): recto: titled, [no.] 112,417 JV [circled] l.l.; verso: publisher imprint, trademark, post template

Inscriptions: verso: in ink: Dear May When the postman came this a. m. I was just wishing for a letter from someone and was surprised when one was handed out to me. We had no trouble getting here but there certainly was a crowd at the univ (?) This is a nice place and am having a nice time too Art is going to Kitchener this afternoon with Robt. Did you see or hear any more of Albert? What a pity you didn't phone Duggan Ave before Miss May Berry Walker's Point Muskoka Ont.

Notes: To the left is the Gooderham Fountain named after George $\mathrm{H}$. Gooderman, the president of the CNE Association from 1909 to 1911 . The Gooderham Fountain was constructed in 1910 and was replaced with the Princess Margaret Fountain in 1958. In the distance is the Manufacturers and Liberal Arts Building designed by Architect George William Gouinlock (1861-1932) and constructed in 1902. The Women's Building was added to the original building in 1908. The building was destroyed by fire in 1961 and was replaced by the Better Living Centre Alternate Number: AG0.98676 


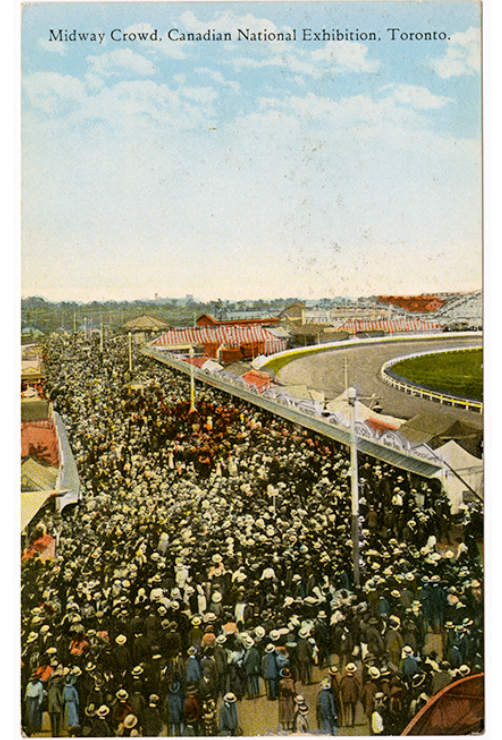

Recto

G0 Accession Number: 2011/212

Classification: Photography Collection Constituents:

Publisher: Novelty and Art Mfg. Co.

Ltd., Montreal, Can.

Photographer: Unknown

Constituents Note: Novelty and Art Mfg. Co. Ltd., Montreal, Can. was founded in 1912 and terminated operations in 1926 Title: Midway Crowd, Canadian National Exhibition, Toronto

Title Note: Printed

Date(s) of Object: [between 1912 and 1926\}

Date Notes: The Toronto Industrial Exhibition was renamed the Canadian National Exhibition in 1912 and the Novelty and Art Mfg. Co. Ltd., Montreal, Can. commenced and ceased operations between 1912 and 1926 respectively.

Object Name: Postcard

Medium: Letterpress halftone

Dimensions:

Image: $13.6 \times 8.5 \mathrm{~cm}, 5.35 \times 3.35 \mathrm{in}$

Sheet: $13.6 \times 8.5 \mathrm{~cm}, 5.35 \times 3.35$ in

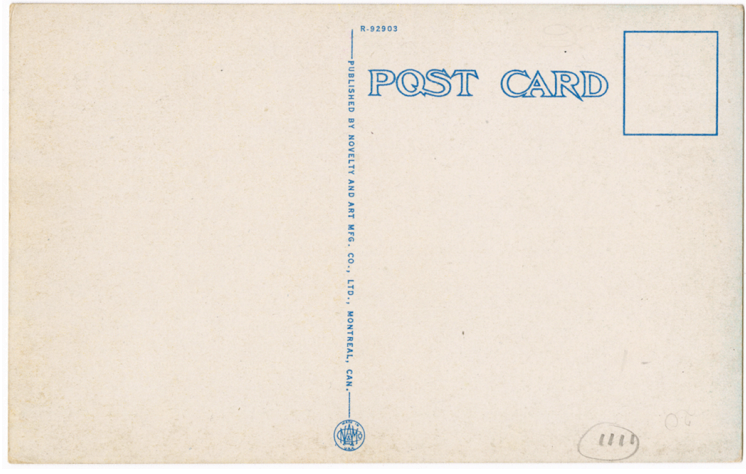

Verso

\section{Geography:}

Place Created: printed in U. S. A.

Place Depicted: An aerial view of the grounds of the Canadian National Exhibition looking east

Mark(s): recto: titled; verso: publisher imprint, post template, trademark, post template, [no.] R-92903

Inscriptions: verso: in graphite: [no.] 1111 [circled] l.r.

Notes: In 1899 an area located south of the road leading from the Main Exhibition Building to the Grandstand was designated 'The Olio-de-Plaisance' (The Place of Amusement).

Alternate Number: AG0.98677 


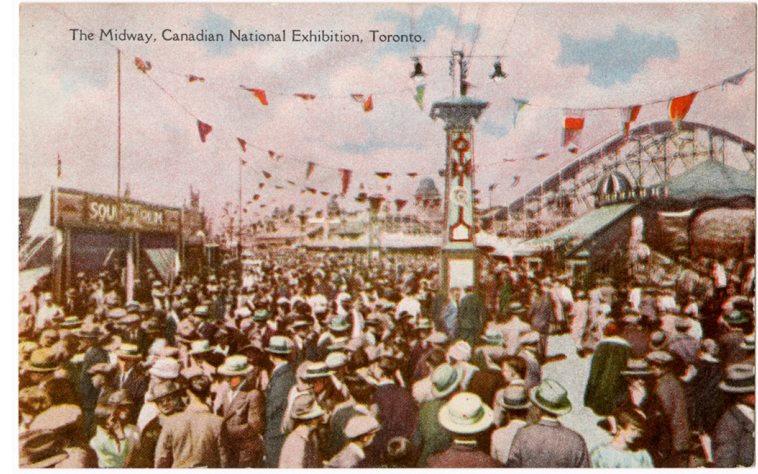

Recto

AG0 Accession Number: 2011/213

Classification: Photography Collection Constituents:

Publisher: Post Card \& Greeting Card Co. Ltd., Toronto

Photographer: Unknown

Constituents Note: Post Card \& Greeting Card Co. Ltd. Toronto was established during the 1920s and terminated operations in 1935

Title: The Midway, Canadian National Exhibition, Toronto

Title Note: Printed Date(s) of Object: [between 1920 and 1935]]

Date Notes: Post Card \& Greeting Co. produced postcards between the 1920s and ceasing production in 1935.

Object Name: Postcard

Medium: Offset lithograph

Dimensions:

Image: $8.7 \times 13.8 \mathrm{~cm}, 3.43 \times 5.43 \mathrm{in}$

Sheet: $8.7 \times 13.8 \mathrm{~cm}, 3.43 \times 5.43 \mathrm{in}$

Geography:

Place Created: Canada

Place Depicted: A view of the grounds of the Canadian National Exhibition Mark(s): recto: titled; verso: publisher imprint, trademark 'CANADA SERIES', 'A happy, surging, never-ending crowd of pleasure-seekers on the Canadian National Exhibition Midway are forever filled with the carnival spirit. It is a street of nations', post template

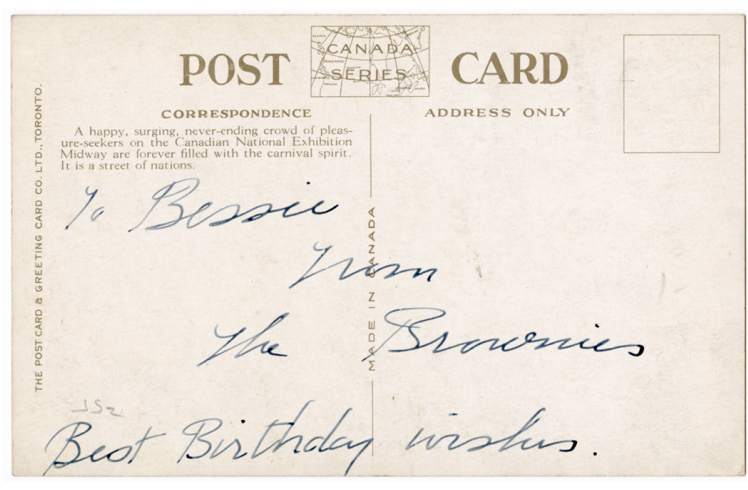

Verso

Inscriptions: verso: in ink: To Bessie from the Brownies Best Birthday wishes.; in graphite JSZ 1.l.

Notes: In 1902, The Midway was located at the eastern end of the Grandstand. By 1910 The Midway boasted rides such as The Gorge, Chute The Chutes and Roller Boller Coaster.

Alternate Number: AG0.98678 


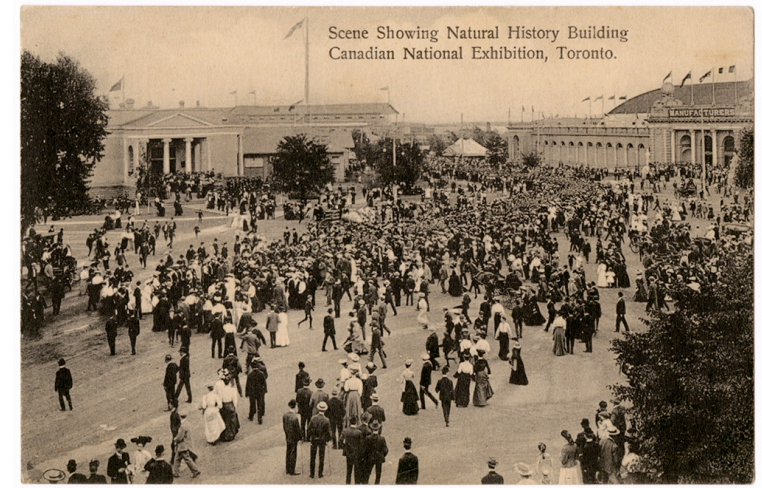

Recto

AGO Accession Number: 2011/214

Classification: Photography Collection Constituents:

Publisher: Walter M. Lowney Co. of

Canada, Limited

Photographer: Unknown

Constituents Note: The Walter M.

Lowney Company, an American candy manufacturer was founded in 1883 in Boston, Massachusetts. In 1905 a candy factory was built in Montreal in 1905, and offices were established in Toronto, Winnipeg, Calgary, and Vancouver.

Title: Scene Showing Natural History Building, Canadian National Exhibition Title Note: Printed

Date(s) of Object: [after 1912]

Date Notes: The Toronto Industrial Exhibition was renamed the Canadian National Exhibition in 1912. Previous entry 1910s

Object Name: Postcard

Medium: Collotype

Dimensions:

Image: $8.9 \times 13.6 \mathrm{~cm}, 3.50 \times 5.35 \mathrm{in}$

Sheet: $8.9 \times 13.6 \mathrm{~cm}, 3.50 \times 5.35$ in

Geography:

Place Created: Germany

Place Depicted: A view of the grounds of the Canadian National Exhibition looking east toward the Grandstand and the Manufacturers and Liberal Arts Building

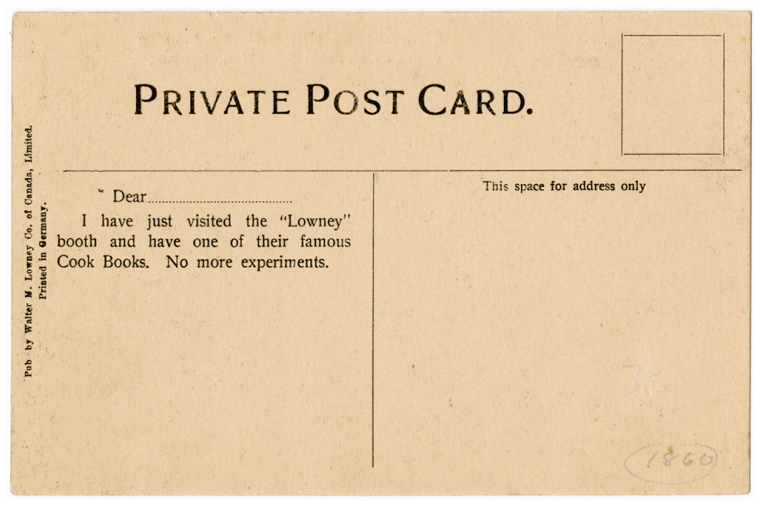

Verso

Mark(s): recto: titled; verso: publisher imprint, 'Dear...I have just visited the 'Lowney" booth and have one of their famous Cook Books. No more experiments', post template Inscriptions: verso: in graphite: [no] 1860 [circled] l.r.

Notes: In the distance to the left is the Grandstand constructed in 1895. To the right is the Manufacturers and Liberal Arts Building designed by Architect Gouinlock and constructed in 1902. The Women's Building was added to the original building in 1908. It was destroyed by fire in 1961 and replaced by the Better Living Centre designed by the architectural firm of Marani, Morris \& Allan (1959-1964) in 1962.

Alternate Number: AG0.98679 


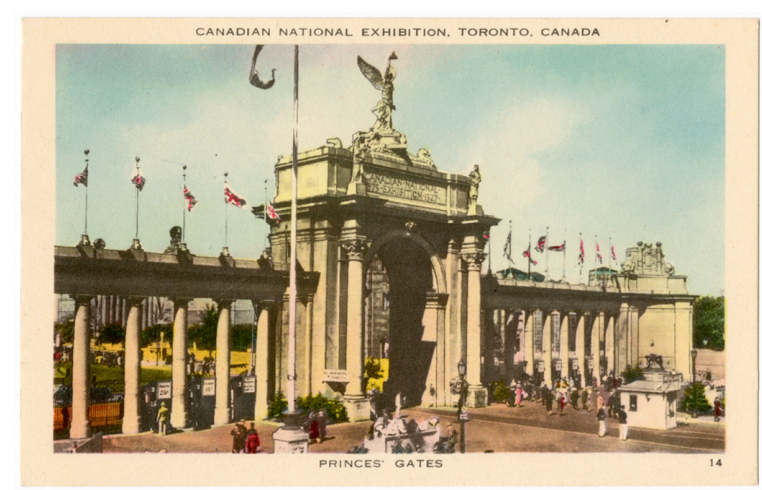

Recto

AGO Accession Number: 2011/215

Classification: Photography Collection

Constituents:

Publisher: Valentine-Black Co., Ltd., Toronto, Canada

Photographer: Unknown

Constituents Note: Valentine-Black Co., Ltd., maintained operations in Toronto from 1922 to 1933. Previous entry Valentine \& Sons Co. Ltd..

Title: Canadian National Exhibition, Toronto, Canada - Princes' Gates

Title Note: Printed

Date(s) of Object: [between 1927 and 1933]

Date Notes: Valentine-Black Co., Ltd., commenced and ceased operation between 1922 and 1933 respectively.

Object Name: Postcard

Medium: Offset lithograph

Dimensions:

Image: $7.7 \times 12.7 \mathrm{~cm}, 3.03 \times 5.00 \mathrm{in}$

Sheet: $8.9 \times 14.0 \mathrm{~cm}, 3.50 \times 5.51$ in

\section{Geography:}

Place Created: Unknown

Place Depicted: A view of the Princes'

Gates looking northwest from Lake

Shore Boulevard

Mark(s): recto: titled, [no.] 14 l.r.; verso: publisher imprint, trademark 'Bond Street Series', post template Inscriptions: verso: in graphite: GC2 l.r.

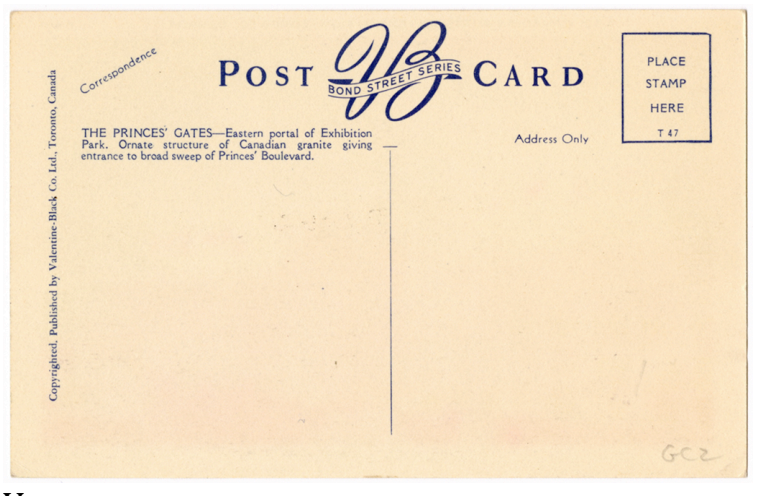

Verso

Notes: Named after Prince Edward (the Prince of Wales) and Prince George, and designed by Architects Alfred

Hirschfelder Chapman (1879-1949) and James Morrow Oxley (1883-1957) the Princes' Gates were constructed in 1927 in the Imperial Classical style. The Gates were officially opened in August 1927. The statue Winged Victory atop the main arch symbolizes progress and advance and was carved by Charles McKechnie. In 1987, the Winged Victory was replaced with a glass-reinforced polymer plastic copy due to deterioration.

Alternate Number: AG0.98680 


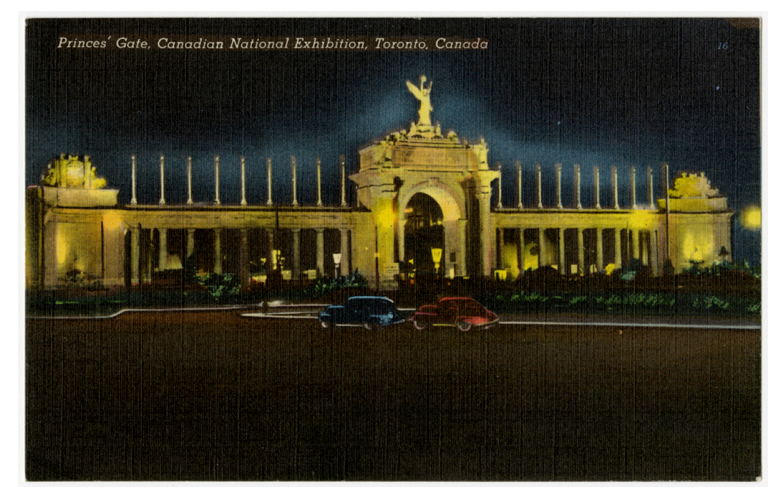

Recto

AGO Accession Number: 2011/216

Classification: Photography Collection

\section{Constituents:}

Publisher: Royal Specialty Sales Co.

Photographer: Unknown

Constituents Note: Royal Specialty Sales

Co. was founded in Toronto in 1937 and presently maintains offices in East York, Toronto

Title: Princes' Gate, Canadian National

Exhibition, Toronto, Canada

Title Note: Printed

Date(s) of Object: [between 1937 and 1945]

Date Notes: The appearance of a 'linen'

finish and the vivid colours indicate production dates from1930 to 1945 .

However the Royal Specialty Sales Co. did not commence operations until 1937.

Object Name: Postcard

Medium: Offset lithograph

Dimensions:

Image: $8.7 \times 13.9 \mathrm{~cm}, 3.43 \times 5.47 \mathrm{in}$

Sheet: $8.7 \times 13.9 \mathrm{~cm}, 3.43 \times 5.47 \mathrm{in}$

Geography:

Place Created: Canada

Place Depicted: A view of the Princes'

Gates looking northwest from Lake

Shore Boulevard

Mark(s): recto: titled; verso: publisher

imprint, trademark 'Colourpicture

Publication', post template, [no.] K1333

t.c.

Inscriptions: verso: in graphite: GC2 l.r.

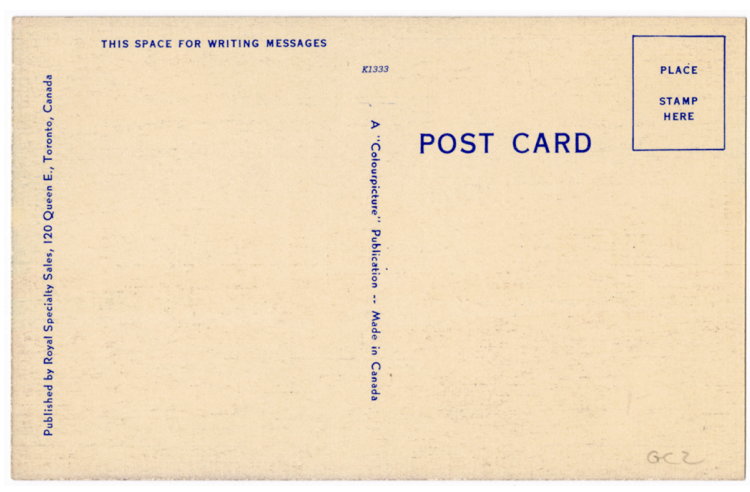

Verso

Notes: Named after Prince Edward (the Prince of Wales) and Prince George, and designed by Architects Alfred Hirschfelder Chapman (1879-1949) and James Morrow Oxley (1883-1957) the Princes' Gates were constructed in 1927 in the Imperial Classical style. The Gates were officially opened in August 1927. The statue Winged Victory atop the main arch symbolizes progress and advance and was carved by Charles McKechnie. In 1987, the Winged Victory was replaced with a glass-reinforced polymer plastic copy due to deterioration.

Alternate Number: AG0.98681 


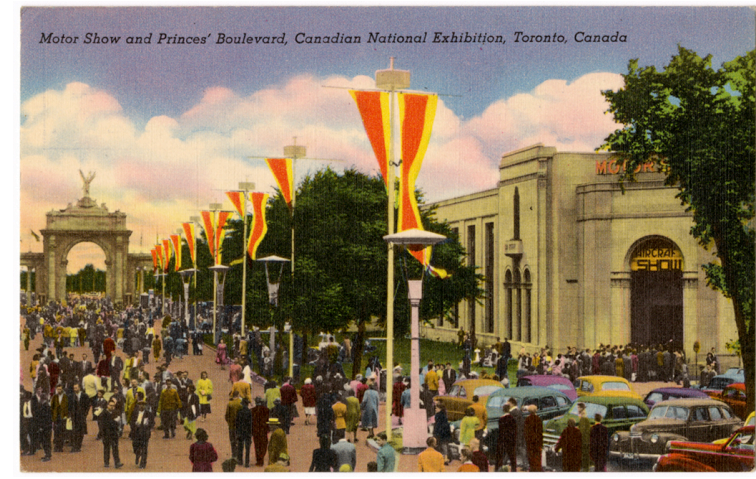

Recto

AGO Accession Number: 2011/217

Classification: Photography Collection

\section{Constituents:}

Publisher: Royal Specialty Sales Co.

Photographer: Unknown

Constituents Note: Royal Specialty Sales

Co. was founded in Toronto in 1937 and

presently maintains offices in East York,

Toronto

Title: Motor Show and Princes'

Boulevard, Canadian National Exhibition,

Toronto, Canada

Title Note: Printed

Date(s) of Object: [between 1937 and 1945]

Date Notes: The appearance of a 'linen' finish and the vivid colours indicate production dates from1930 to 1945 . However the Royal Specialty Sales Co. did not commence operations until 1937.

Object Name: Postcard

Medium: Offset lithograph

Dimensions:

Image: $8.6 \times 13.9 \mathrm{~cm}, 3.39 \times 5.47$ in

Sheet: $8.6 \times 13.9 \mathrm{~cm}, 3.39 \times 5.47$ in

\section{Geography:}

Place Created: Canada

Place Depicted: A view of the grounds of the Canadian National Exhibition looking east towards the Princes' Gates Mark(s): recto: titled; verso: publisher imprint, trademark 'Colourpicture Publication', post template, [no.] K3565 t.c., 'CANADIAN NATIONAL EXHIBITION

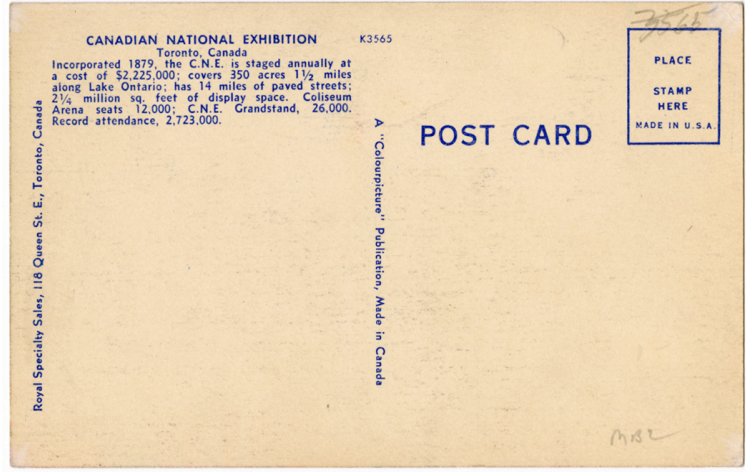

Verso

Toronto, Canada Incorporated 1879, the C. N. E. is staged annually at a cost of $\$ 2,225,000$; covers 350 acres $1^{1 / 2}$ miles along Lake Ontario; has 14 miles of paved streets; $2^{1 / 4}$ million sq. feet of display space. Coliseum Arena seats 12,000; C. N. E. Grandstand, 26,000. Record attendance, 2,723,000.

Inscriptions: verso: in graphite: MB2 l.r. Notes: In the distance is the Princes' Gates named after Prince Edward (the Prince of Wales) and Prince George, and designed by Architects Alfred Hirschfelder Chapman (1879-1949) and James Morrow Oxley (1883-1957) the Princes' Gates were constructed in 1927 in the Imperial Classical style. The Gates were officially opened in August 1927. The statue of the Winged Victory atop the main arch symbolizes progress and advance and was carved by Charles McKechnie. In 1987, the Winged Victory was replaced with a glass-reinforced polymer plastic copy due to deterioration. To the right is the Automotive Building designed by Architect Douglas Edwin Kertland (1888-1982) and constructed in 1929 in the Neoclassical Revival and Modern Classical styles.

Alternate Number: AG0.98681 


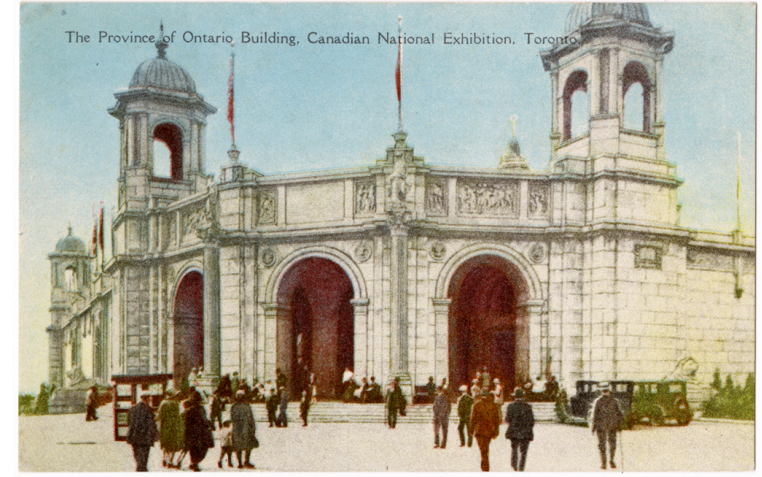

Recto

AGO Accession Number: 2011/218

Classification: Photography Collection Constituents:

Publisher: Post Card \& Greeting Card Co. Ltd., Toronto

Photographer: Unknown

Constituents Note: Post Card \& Greeting Card Co. Ltd. Toronto was established during the 1920s and terminated operations in 1935

Title: The Province of Ontario Building, Canadian National Exhibition, Toronto Title Note: Printed Date(s) of Object: [between 1926 and 1935]

Date Notes: The Province of the Ontario Building was constructed in 1926 and the Post Card \& Greeting Card Co. Ltd. ended operations in 1935.

Object Name: Postcard

Medium: Offset lithograph

Dimensions:

Image: $8.9 \times 13.7 \mathrm{~cm}, 3.50 \times 5.39 \mathrm{in}$

Sheet: $8.9 \times 13.7 \mathrm{~cm}, 3.50 \times 5.39 \mathrm{in}$

Geography:

Place Created: Canada

Place Depicted: A view of the Province of Ontario Building looking west

Mark(s): recto: titled; verso: publisher imprint, trademark 'CANADA SERIES', 'The northern entrance to the Province of Ontario Building, which is considered the finest permanent exhibition building in the world', post template

Inscriptions: verso: in graphite: GC2 l.r.

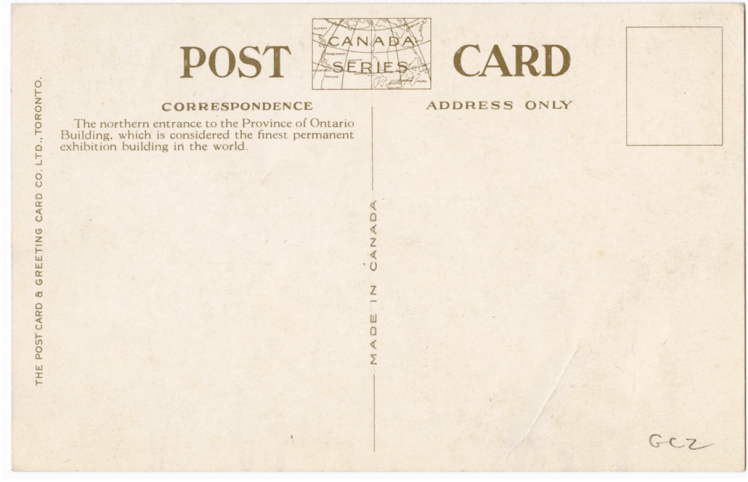

Verso

Notes: Designed by Architects Alfred Hirschfelder Chapman (1879-1949) and James Morrow Oxley (1883-1957) the Province of Ontario Building was constructed in 1926.

Alternate Number: AG0.98683 


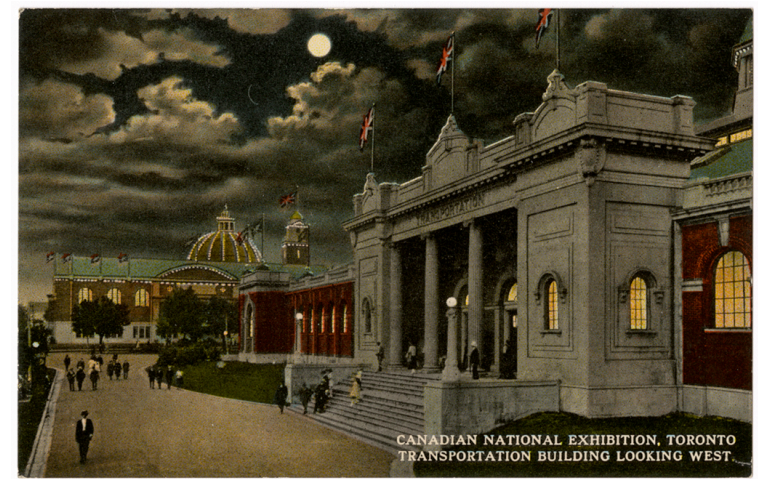

Recto

AGO Accession Number: 2011/219

Classification: Photography Collection

Constituents:

Publisher: E. Zaitchick, Canadian

National Exhibition, Toronto

Photographer: Unknown

Constituents Note: E. Zaitchick and Sons Co. was a concessionaire at the CNE from 1923 onwards.

Title: Canadian National Exhibition, Toronto Transportation Building Looking West

Title Note: Printed

Date(s) of Object: [after 1923]

Date Notes: E. Zaitchick and Sons Co. was a concessionaire at the CNE from 1923 onwards.

Object Name: Postcard

Medium: Letterpress halftone

Dimensions:

Image: $8.7 \times 13.6 \mathrm{~cm}, 3.43 \times 5.35 \mathrm{in}$

Sheet: $8.7 \times 13.6 \mathrm{~cm}, 3.43 \times 5.35 \mathrm{in}$

\section{Geography:}

Place Created: printed by C. T.

Photochrom, Chicago, U. S. A.

Place Depicted: A view of the

Transportation Building looking south toward Lake Ontario

Mark(s): recto: titled; verso: publisher imprint, trademark 'C.T. Chicago', post template [no.] a-98624 c.t.

Inscriptions: None

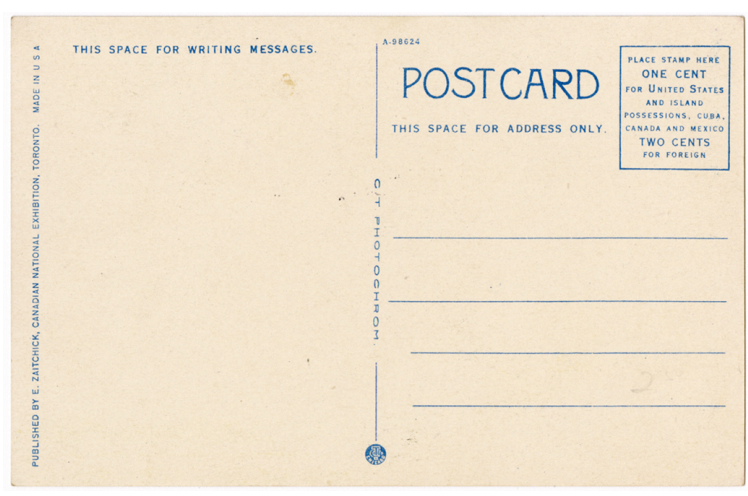

Verso

Notes: To the right is the Transportation Building designed by Architect George William Gouinlock (1861-1932) and constructed in 1909. The building was destroyed by fire in 1974. The site is now occupied by Bandshell Park. In the distance is the Dominion and Provincial Government Building designed by Architect George William Gouinlock (1861-1932) and constructed in the Beaux Arts style in 1912. The building presently houses the dinner theatre Medieval Times Dinner and Tournament. Alternate Number: AG0.98684 


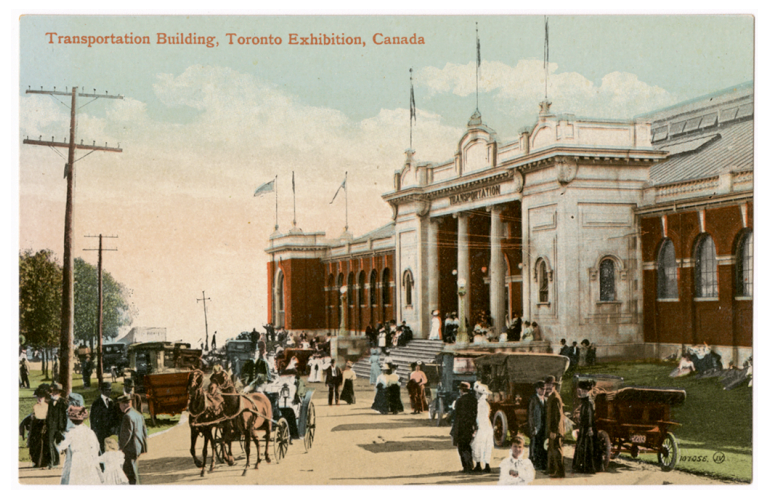

Recto

AGO Accession Number: 2011/220

Classification: Photography Collection Constituents:

Publisher: The Valentine \& Sons United Publishing Co. Ltd. Montreal and

Toronto

Photographer: Unknown

Constituents Note: The Valentine \& Sons Publishing Co. Ltd. was founded in Montreal and Toronto in 1903 and 1906 respectively. Operations were terminated in 1923.

Title: Transportation Building, Toronto Exhibition, Canada

Title Note: Printed Date(s) of Object: [between 1908 and 1912]

Date Notes: This card was printed after Valentine \& Sons began to use the 'FAMOUS THROUGHOUT THE WORLD' trademark in 1908 and prior to the Toronto Industrial Exhibition being renamed the Canadian National Exhibition in 1912.

Object Name: Postcard

Medium: Letterpress halftone

Dimensions:

Image: $8.7 \times 13.6 \mathrm{~cm}, 3.43 \times 5.35 \mathrm{in}$

Sheet: $8.7 \times 13.6 \mathrm{~cm}, 3.43 \times 5.35$ in

Geography:

Place Created: Great Britain

Place Depicted: A view of the

Transportation Building looking south toward Lake Ontario
Verso

Mark(s): recto: titled, [no.] $107056 \mathrm{JV}$ [circled] l.r.; verso: publisher imprint, trademark, post template

Inscriptions: verso: in graphite: [no.] 2606 [circled] l.r.

Notes: To the right is the Transportation Building designed by Architect George William Gouinlock (1861-1932) and constructed in 1909. The building was destroyed by fire in 1974 . The site is now occupied by Bandshell Park

Alternate Number: AG0.98685 


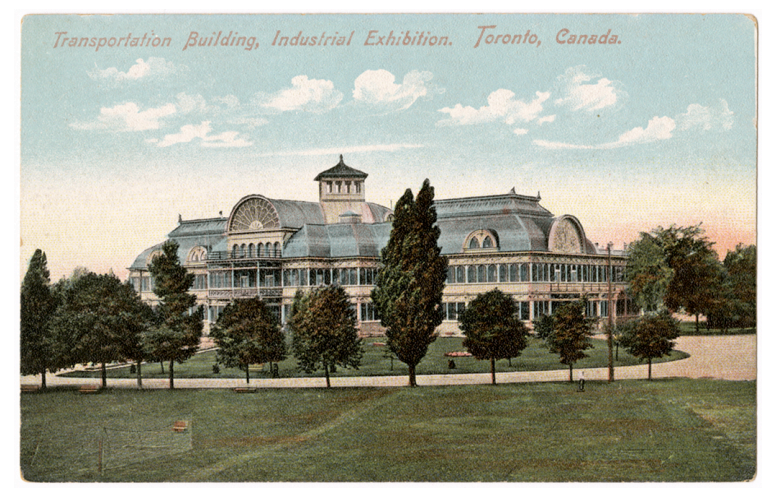

Recto

AGO Accession Number: 2011/221

Classification: Photography Collection Constituents:

Publisher: A.L. Merrill Publishing Co. Photographer: Unknown

Constituents Note: The A.L. Merrill

Publishing Co. maintained offices at 304

Yonge Street in Toronto from 1903 and published postcards during the first decade of the 20th century.

Title: Transportation Building, Industrial Exhibition, Toronto, Canada

Title Note: Printed

Date(s) of Object: 1903

Date Notes: A.L. Merrill Publishing began producing postcards in 1903 and the imprint on the verso stipulating address only indicates an undivided postcard, divided postcards were introduced in Canada in1903.

Object Name: Postcard

Medium: Letterpress halftone

Dimensions:

Image: $8.9 \times 14.0 \mathrm{~cm}, 3.50 \times 5.51 \mathrm{in}$

Sheet: $8.9 \times 14.0 \mathrm{~cm}, 3.50 \times 5.51 \mathrm{in}$

Geography:

Place Created: Germany

Place Depicted: A view of the Crystal Palace (also known as the Palace of Industry) looking northwest

Mark(s): recto: titled; verso: publisher imprint, [no.] 201281 l.l., post template Inscriptions: verso. In graphite: SM [circled] l.r.
POST CARD

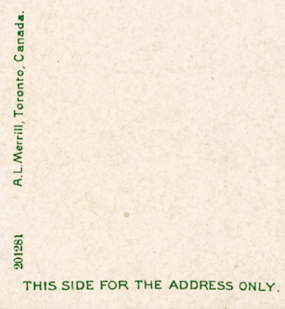

Verso

Notes: Identified as the Transportation Building, the image depicts the Crystal Palace. The original Crystal Palace (also known as the Palace of Industry) was designed by Sanford Fleming and Collingwood Schreiber and constructed north of King Street and west of Shaw Street in 1858. The building was dismantled and moved to Exhibition place in 1878. Architects William Stewart (1832-1907) and Walter Reginald Strickland (1841-1915) oversaw the addition of a third floor, raised dormers and skylights to the original building. The Crystal Palace was destroyed by fire in 1906.

Alternate Number: AG0.98686 


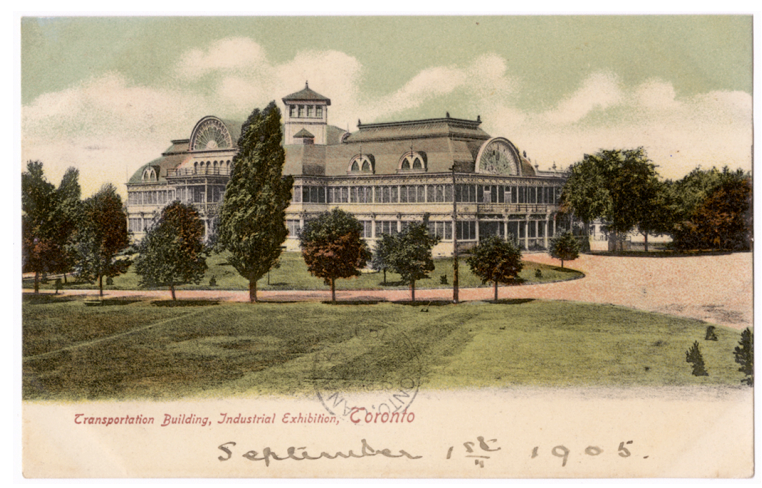

Recto

AGO Accession Number: 2011/222

Classification: Photography Collection

Constituents:

Publisher: Unknown

Photographer: Unknown

Constituents Note: None

Title: Transportation Building, Industrial Exhibition, Toronto

Title Note: Printed

Date(s) of Object: 1905

Date Notes: This card is postmarked

September 2, 1905.

Object Name: Postcard

Medium: Collotype

Dimensions:

Image: $8.7 \times 13.9 \mathrm{~cm}, 3.43 \times 5.47$ in

Sheet: $8.7 \times 13.9 \mathrm{~cm}, 3.43 \times 5.47 \mathrm{in}$

\section{Geography:}

Place Created: unknown

Place Depicted: A view of the Crystal

Palace (also known as the Palace of

Industry) looking northwest

Mark(s): recto: titled; verso: post

template

Inscriptions: recto, in ink: September $1^{\text {st }}$ 1905; verso: in ink: Best wishes from E. A. N. (?) Mr F. G. 233 Brunswick Ave Toronto Ontario; in graphite: [no.] 2727 [circled]

l.l.

Notes: Identified as the Transportation Building, the image depicts the Crystal Palace. The original Crystal Palace (also known as the Palace of Industry) was designed by Sanford Fleming and Collingwood Schreiber and constructed

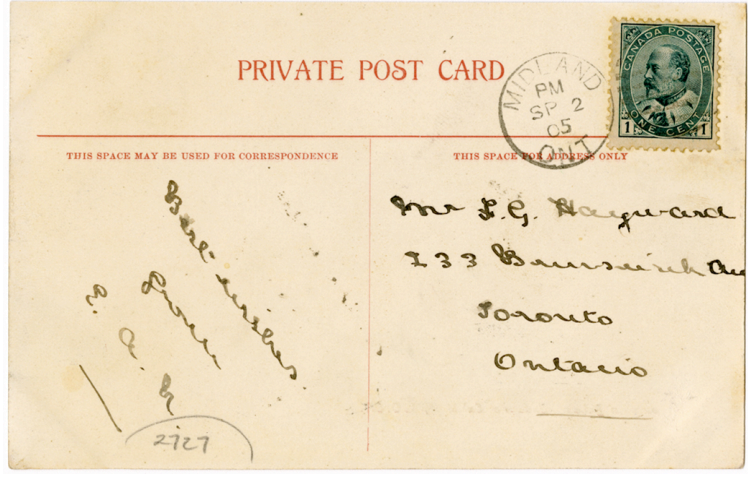

Verso

north of King Street and west of Shaw Street in 1858. The building was dismantled and moved to Exhibition place in 1878. Architects William Stewart (1832-1907) and Walter Reginald Strickland (1841-1915) oversaw the addition of a third floor, raised dormers and skylights to the original building. The Crystal Palace was destroyed by fire in 1906.

Alternate Number: AG0.98687 


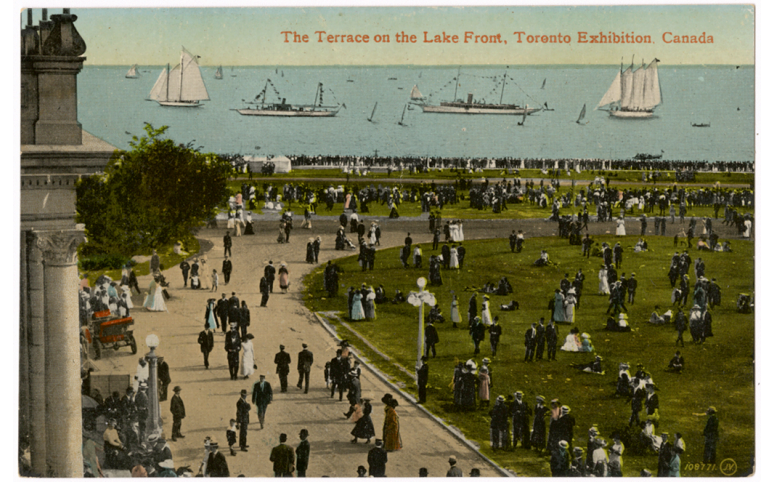

Recto

AGO Accession Number: 2011/223

Classification: Photography Collection Constituents:

Publisher: The Valentine \& Sons

Publishing Co. Ltd. Montreal and

Toronto

Photographer: Unknown

Constituents Note: The Valentine \& Sons

Publishing Co. Ltd. was founded in

Montreal and Toronto in 1903 and 1906

respectively. Operations were terminated in 1923.

Title: The Terrace on the Lake Front,

Toronto Exhibition, Canada

Title Note: Printed

Date(s) of Object: [between 1908 and 1912]

Date Notes: This card was printed after

Valentine \& Sons began to use the 'FAMOUS THROUGHOUT THE WORLD' trademark in 1908 and prior to the Toronto Industrial Exhibition renamed the Canadian National Exhibition in 1912.

Object Name: Postcard

Medium: Letterpress halftone

Dimensions:

Image: $8.7 \times 13.6 \mathrm{~cm}, 3.43 \times 5.35$ in

Sheet: $8.7 \times 13.6 \mathrm{~cm}, 3.43 \times 5.35$ in

Geography:

Place Created: Great Britain

Place Depicted: An aerial view taken

from the Manufacturers and Liberal

Arts Building of the pedestrian

walkways looking south towards Lake

Ontario
Verso

Mark(s): recto: titled, [no.] $108771 \mathrm{JV}$ [circled] l.r.; verso: publisher imprint, trademark, post template

Inscriptions: verso: in graphite: [no.] 2937 [circled] l.r.

Notes: Designed by Architect George William Gouinlock (1861-1932) the Manufacturers and Liberal Arts Building was constructed in 1902. The Women's Building was added to the original building in 1908. The building was destroyed by fire in 1961 and was replaced by the Better Living Centre.

Alternate Number: AGO.98688 


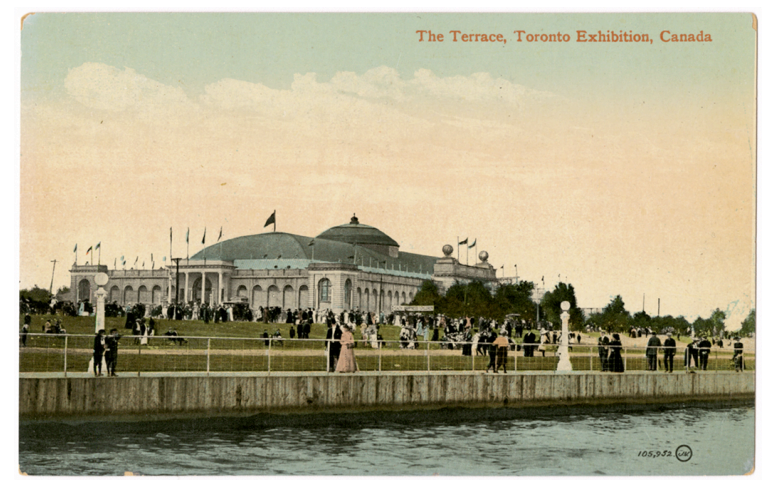

Recto

AGO Accession Number: 2011/224

Classification: Photography Collection Constituents:

Publisher: The Valentine \& Sons

Publishing Co. Ltd. Montreal and

Toronto

Photographer: Unknown

Constituents Note: The Valentine \& Sons

Publishing Co. Ltd. was founded in

Montreal and Toronto in 1903 and 1906

respectively. Operations were terminated in 1923.

Title: The Terrace, Toronto Exhibition, Canada

Title Note: Printed

Date(s) of Object: [between 1908 and 1912]

Date Notes: This card was printed after Valentine \& Sons began to use the 'FAMOUS THROUGHOUT THE WORLD' trademark in 1908.and prior to the Toronto Industrial Exhibition renamed the Canadian National Exhibition in 1912.

Object Name: Postcard

Medium: Letterpress halftone

Dimensions:

Image: $8.7 \times 13.8 \mathrm{~cm}, 3.43 \times 5.43 \mathrm{in}$

Sheet: $8.7 \times 13.8 \mathrm{~cm}, 3.43 \times 5.43$ in

Geography:

Place Created: Great Britain

Place Depicted: A view of the

Manufacturers and Liberal Arts

Building including the Terrace taken

from Lake Ontario

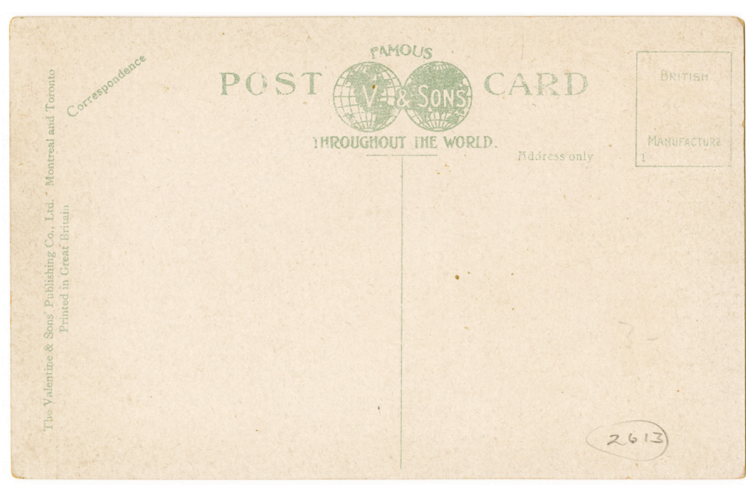

Verso

Mark(s): recto: titled, [no.] 105,952 JV [circled] l.r.; verso: publisher imprint, trademark, post template Inscriptions: verso: in graphite: [no.] 2613 [circled] l.r.

Notes: In the distance is the Manufacturers and Liberal Arts Building designed by architect George William Gouinlock (1861-1932) and constructed in 1902. The Women's Building was added to the original building in 1908 . The building was destroyed by fire in 1961 and was replaced by the Better Living Centre. At this time the Toronto Exhibition went up to the edge of Lake Ontario. In the 1920s the Toronto Harbour Commission undertook plans to develop the waterfront. As a result the Canandian National Exhibition benefited with the addition of 200 acres and the construction of Boulevard Drive (renamed Lake Shore Boulevard) in 1921. Alternate Number: AGO.98689 


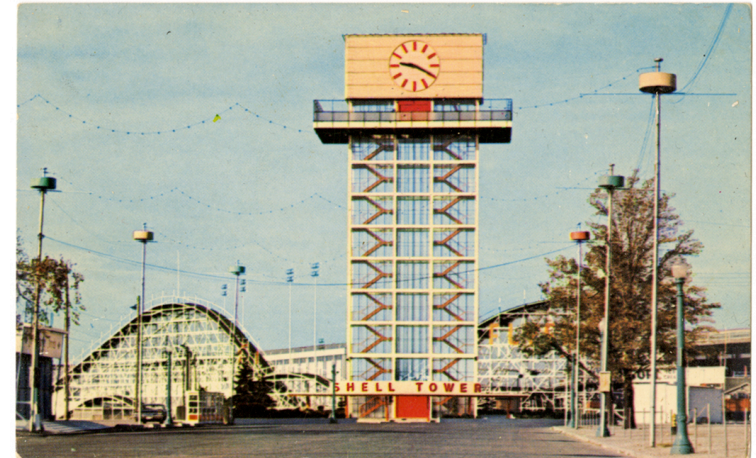

Recto

AGO Accession Number: 2011/225

Classification: Photography Collection Constituents:

Publisher: Royal Specialty Sales Co.

Photographer: Unknown

Constituents Note: Royal Specialty Sales Co. was founded in Toronto in 1937 and presently maintains offices in East York, Toronto

Title: The Shell Tower Canadian National Exhibition, Toronto, Ontario, Canada

Title Note: Printed Date(s) of Object: [between 1955 and 1964]

Date Notes: The Shell Tower was constructed in 1955. Colourpicture Publications the printer of the postcard appears to have changed their trademark on the verso of card ca. 1964.

Object Name: Postcard

Medium: Offset lithograph

Dimensions:

Image: $8.8 \times 14.2 \mathrm{~cm}, 3.46 \times 5.59$ in

Sheet: $8.8 \times 14.2 \mathrm{~cm}, 3.46 \times 5.59$ in

Geography:

Place Created: Boston Mass. U. S. A.

Place Depicted: A view of the Shell

Tower located on Princes' Boulevard looking west

Mark(s): verso: titled, publisher imprint, publisher address ' 430 King St. W.

Toronto, Ontario, trademark 'Plastichrome', printer address 'Boston 30, Mass., U. S. A., [no.] P62393 t.c., post template

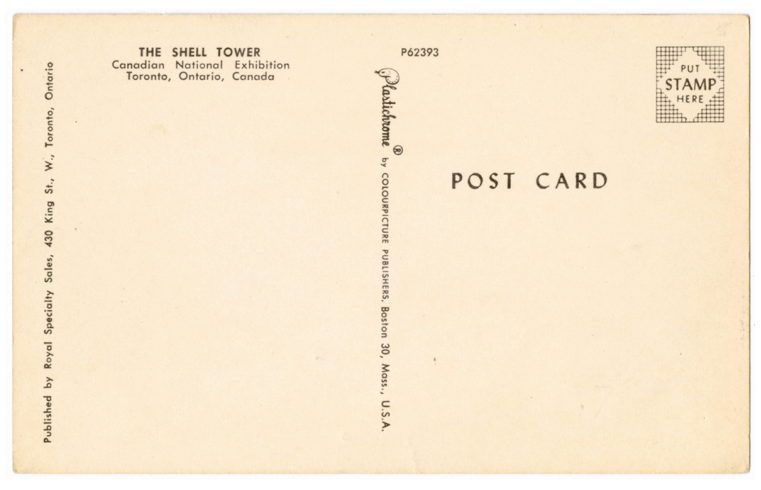

Verso

Inscriptions: None

Notes: Designed by Architect George

Robb (1923-1991) the Shell Tower

(renamed the Bulova Tower in 1973) was constructed in 1955. The tower was declared unsafe in 1983 and was demolished in 1985.

Alternate Number: AGO.98690 


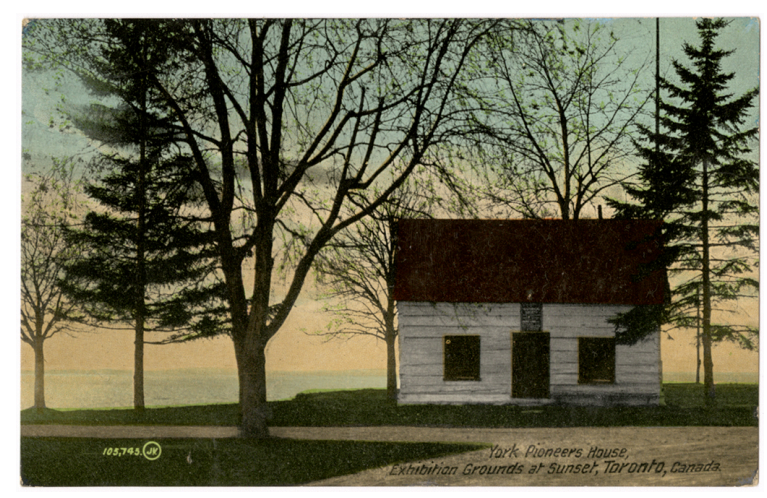

Recto

AG0 Accession Number: 2011/226

Classification: Photography Collection

Constituents:

Publisher: The Valentine \& Sons

Publishing Co. Ltd. Montreal and

Toronto

Photographer: Unknown

Constituents Note: The Valentine \& Sons

Publishing Co. Ltd. was founded in

Montreal and Toronto in 1903 and 1906

respectively. Operations were terminated in 1923.

Title: York Pioneers House, Exhibition

Grounds at Sunset, Toronto, Canada

Title Note: Printed

Date(s) of Object: [between 1908 and 1910]

Date Notes: The card is postmarked August 27, 1910 and was printed after Valentine \& Sons began to use the 'FAMOUS THROUGHOUT THE WORLD' trademark in 1908.

Object Name: Postcard

Medium: Letterpress halftone

Dimensions:

Image: $8.7 \times 13.7 \mathrm{~cm}, 3.43 \times 5.39$ in

Sheet: $8.7 \times 13.7 \mathrm{~cm}, 3.43 \times 5.39$ in

Geography:

Place Created: Great Britain

Place Depicted: A view of Scadding

Cabin looking west toward Lake Ontario

Mark(s): recto: titled, [no.] 105,745 JV

[circled] 1.l.; verso: publisher imprint, trademark, post template

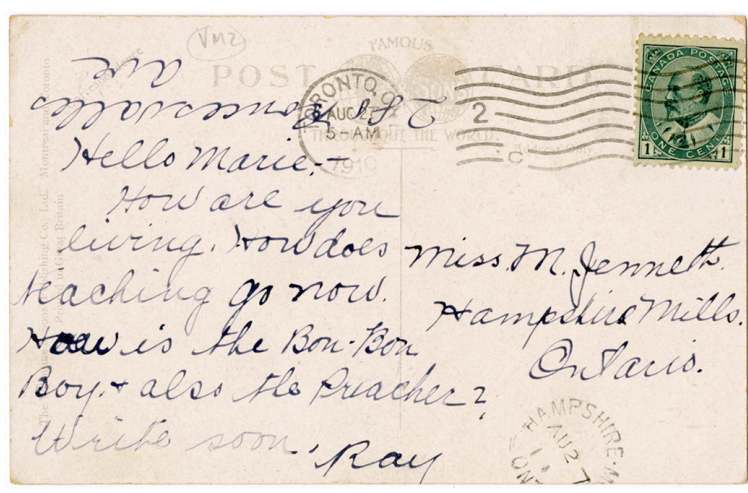

Verso

Inscriptions: verso: in ink: Hello Marie How are you living. How does teaching go now. How is the Bon Bon Boy \& also the Preacher? Write soon. Ray Miss M. Jennette Hampshire Mills Ontario 28 Roncesvalles Ave; in graphite: VM2 t.l. Notes: The Queen's Rangers constructed Scadding Cabin for John Scadding, Lieutenant-Governor John Graves Simcoe's clerk in 1794. Constructed of squared, white pine logs with dovetailed corners the cabin is furnished with artifacts dating from 1790 to the 1850s. The Young Pioneer Society formed in 1869 relocated the cabin from the east bank of the Don River to its present site on the grounds of Exhibition Place in 1879.

Alternate Number: AG0.98691 


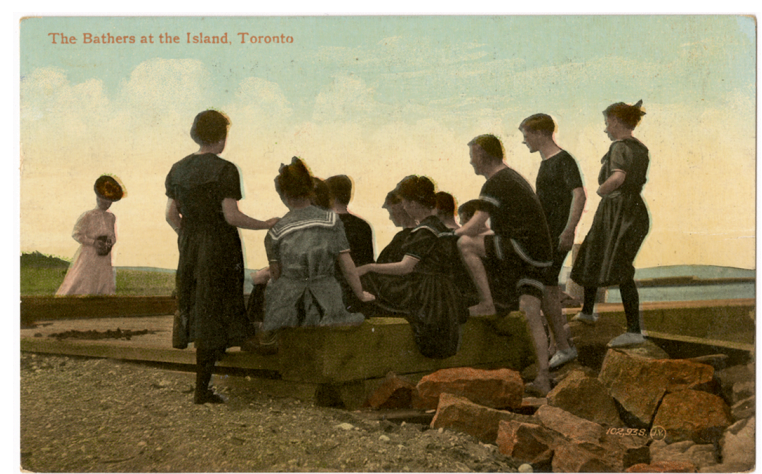

Recto

AGO Accession Number: 2011/227

Classification: Photography Collection Constituents:

Publisher: The Valentine \& Sons

Publishing Co. Ltd. Montreal and

Toronto

Photographer: Unknown

Constituents Note: The Valentine \& Sons

Publishing Co. Ltd. was founded in

Montreal and Toronto in 1903 and 1906

respectively. Operations were terminated in 1923.

Title: The Bathers at the Island, Toronto

Title Note: Printed

Date(s) of Object: 1908

Date Notes: The card is postmarked

August 8, 1908 and was printed prior to when Valentine \& Sons began to use the 'FAMOUS THROUGHOUT THE WORLD' trademark in 1908.

Object Name: Postcard

Medium: Letterpress halftone

Dimensions:

Image: $8.6 \times 13.8 \mathrm{~cm}, 3.39 \times 5.43$ in

Sheet: $8.6 \times 13.8 \mathrm{~cm}, 3.39 \times 5.43$ in

Geography:

Place Created: Great Britain

Place Depicted: Unknown

Mark(s): recto: titled, [no.] 102,938. JV

[circled] l.r.; verso: publisher imprint, trademark, post template

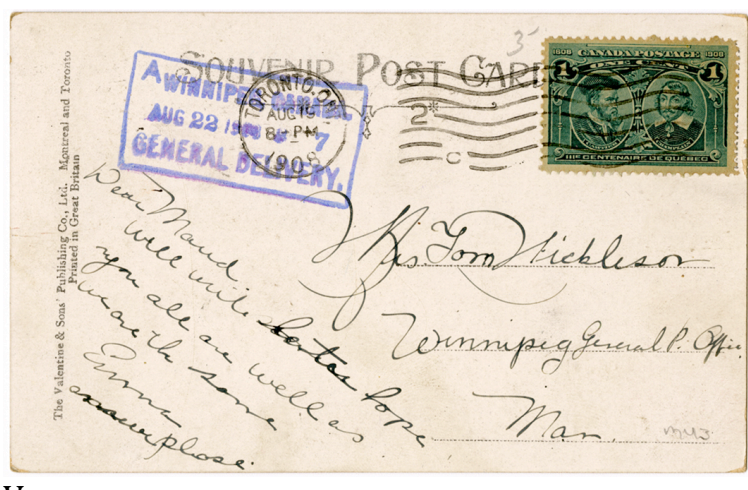

Verso

Inscriptions: verso: in ink: Dear Maud will write later hop you all are well as we are the same Emma answer please Mrs. Tom Nickleson Winnipeg General P. Office Man.; in graphite: MY3 l.r.; 3 t.r.

Notes: Prior to 1910 women's kneelength swimming costumes were black in colour made from wool and featured a sailor collar. The bathing costume was worn over long black stockings. Men's swimming costumes also made from wool, featured elbow and knee length sleeves and trousers.

Alternate Number: AG0.98692 


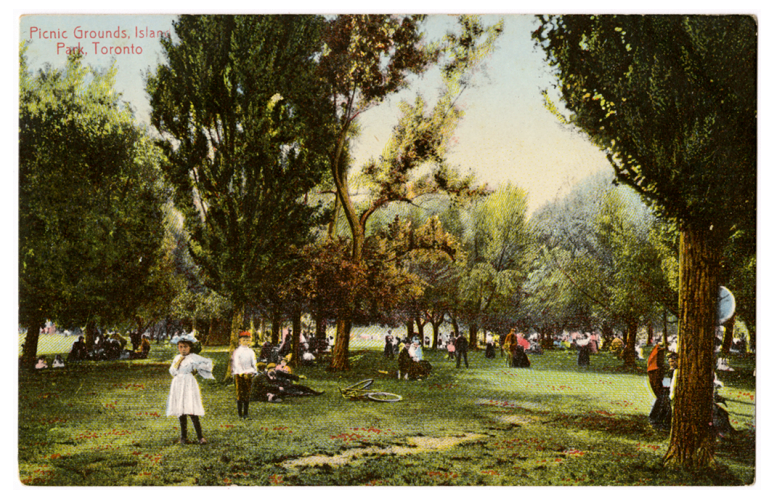

Recto

AGO Accession Number: 2011/228

Classification: Photography Collection

Constituents:

Publisher: W. G. MacFarlane Publisher

\& Importer

Photographer: Unknown

Constituents Note: The W. G. MacFarlane

Publishing Co. Ltd. Toronto maintained offices in Toronto commencing in 1899 and published postcards between 1902 and 1910.

Title: Picnic Grounds Island Park,

Toronto

Title Note: Printed

Date(s) of Object: [between 1902 and 1910]

Date Notes: The W. G. MacFarlane

Publishing Co. Ltd produced postcards

from 1902 to 1910.

Object Name: Postcard

Medium: Letterpress halftone

Dimensions:

Image: $8.7 \times 13.8 \mathrm{~cm}, 3.43 \times 5.43$ in

Sheet: $8.7 \times 13.8 \mathrm{~cm}, 3.43 \times 5.43 \mathrm{in}$

Geography:

Place Created: Germany

Place Depicted: A view looking north of picnic grounds on the city side of Centre Island

Mark(s): recto: titled; verso: publisher imprint, [no.] I. 103 S. t.l., post template

Inscriptions: verso: in graphite: [no.] 385 [circled] l.r.

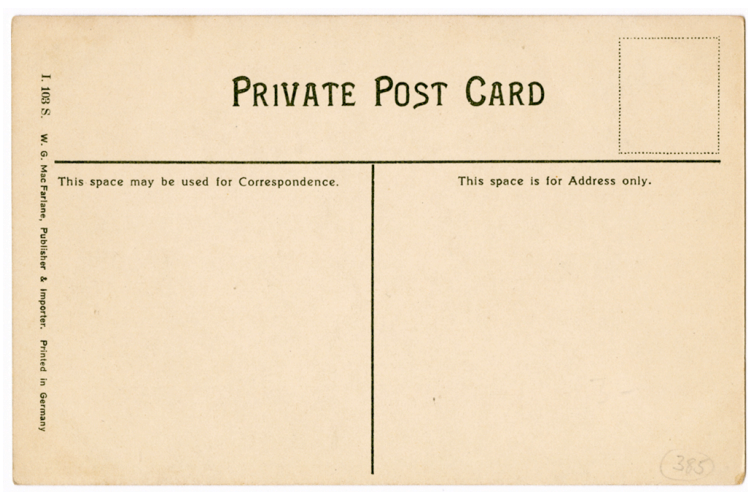

Verso

Notes: As early as 1881 the City of Toronto Council undertook improvements of Centre Island including the construction of the City Wharf, new plank sidewalks, the dredging and filling of ponds. In 1887, Parks Superintendent John Chambers undertook the implementation of an ambitious plan for the improvement of Island Park. Island Park was opened to the public in July and August of 1888.

Alternate Number: AG0.98693 


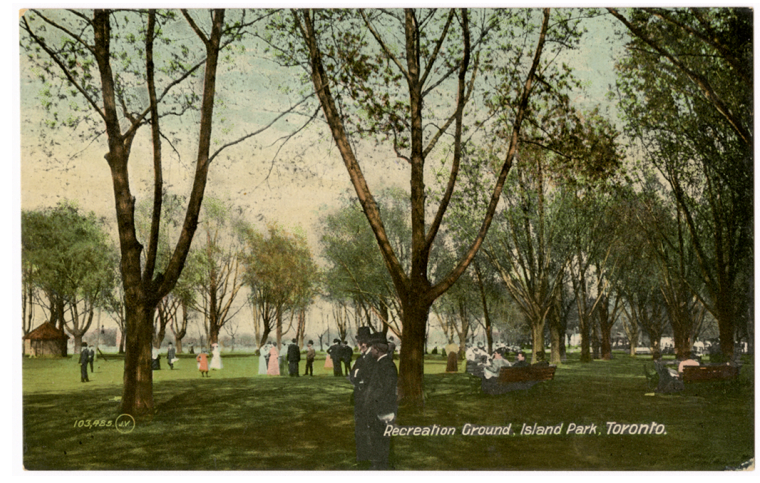

Recto

AG0 Accession Number: 2011/229

Classification: Photography Collection

Constituents:

Publisher: The Valentine \& Sons

Publishing Co. Ltd. Montreal and

Toronto

Photographer: Unknown

Constituents Note: The Valentine \& Sons

Publishing Co. Ltd. was founded in

Montreal and Toronto in 1903 and 1906

respectively. Operations were terminated in 1923..

Title: Recreation Ground, Island Park,

Toronto

Title Note: Printed

Date(s) of Object: [between 1903 and 1908]

Date Notes: The Valentine \& Sons

commenced production of postcards in Canada in 1903. This card was printed prior to when the company began to use the 'FAMOUS THROUGHOUT THE

WORLD' trademark in 1908.

Object Name: Postcard

Medium: Letterpress halftone

Dimensions:

Image: $8.6 \times 13.6 \mathrm{~cm}, 3.39 \times 5.35 \mathrm{in}$

Sheet: $8.6 \times 13.6 \mathrm{~cm}, 3.39 \times 5.35 \mathrm{in}$

Geography:

Place Created: Great Britain

Place Depicted: A view looking north of picnic grounds on the city side of Centre Island

\section{SOUVENIR POST GARD}

in

Verso

Mark(s): recto: titled, [no.] 103,485 JV [circled] l.l.; verso: publisher imprint, trademark 'Souvenir Post Card', post template

Inscriptions: verso: in graphite: squiggly line l.r.

Notes: As early as 1881 the City of Toronto Council undertook improvements of Centre Island including the construction of the City Wharf, new plank sidewalks, the dredging and filling of ponds. In 1887, Parks Superintendent John Chambers undertook the implementation of an ambitious plan for the improvement of Island Park. Island Park was opened to the public in July and August of 1888.

Alternate Number: AG0.98694 


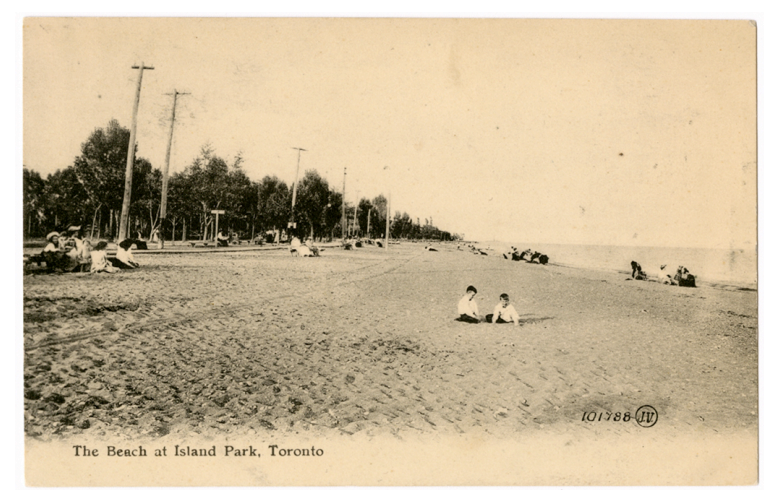

Recto

AGO Accession Number: 2011/230

Classification: Photography Collection

Constituents:

Publisher: The Valentine \& Sons

Publishing Co. Ltd. Montreal and

Toronto

Photographer: Unknown

Constituents Note: The Valentine \& Sons

Publishing Co. Ltd. was founded in

Montreal and Toronto in 1903 and 1906

respectively. Operations were terminated in 1923.

Title: The Beach at Island Park, Toronto

Title Note: Printed

Date(s) of Object: [between 1903 and 1908]

Date Notes: This card was printed prior to when Valentine \& Sons began to use the 'FAMOUS THROUGHOUT THE WORLD' trademark in 1908.

Object Name: Postcard

Medium: Collotype

Dimensions:

Image: $8.0 \times 13.6 \mathrm{~cm}, 3.15 \times 5.35 \mathrm{in}$

Sheet: $8.7 \times 13.6 \mathrm{~cm}, 3.43 \times 5.35$ in

\section{Geography:}

Place Created: Great Britain

Place Depicted: Looking east on the Lake Ontario side of Centre Island. The boardwalk is visible on the right below the poles

\section{SOUVENIR POST GARD}

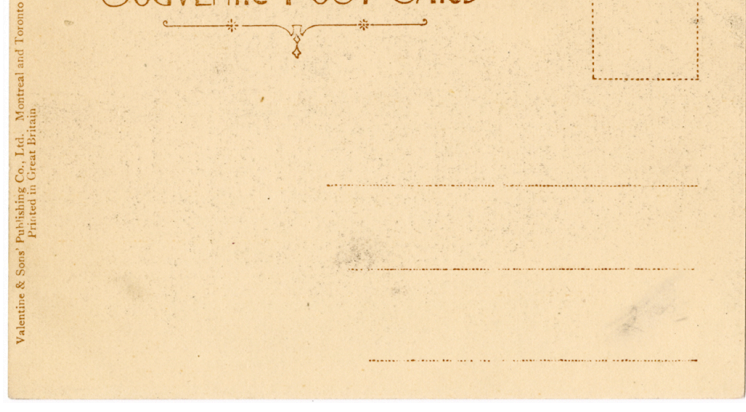

Verso

Mark(s): recto: titled, [no.] 101788 JV [circled] l.r.; verso: publisher imprint, trademark 'Souvenir Post Card', post template

Inscriptions: verso: in graphite: unreadable name (?) t.r.

Notes: As early as 1881 the City of Toronto Council undertook improvements of Centre Island including the construction of the City Wharf, new plank sidewalks, the dredging and filling of ponds. In 1887, Parks Superintendent John Chambers undertook the implementation of an ambitious plan for the improvement of Island Park. Island Park was opened to the public in July and August of 1888.

Alternate Number: AGO.98695 


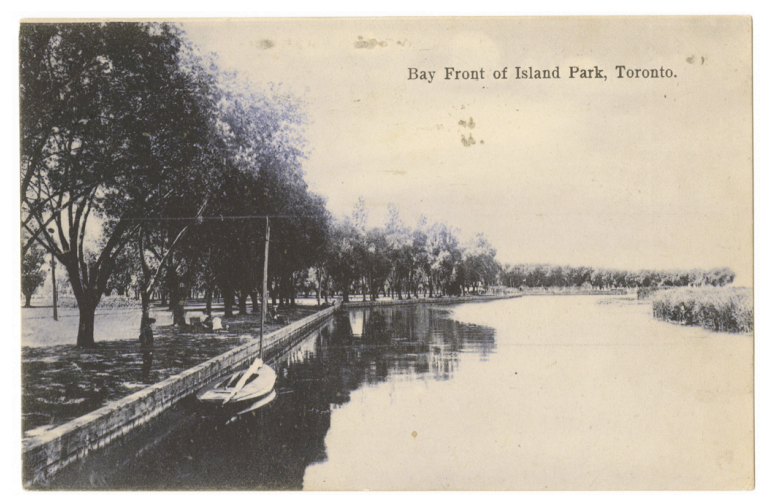

Recto

AGO Accession Number: 2011/231

Classification: Photography Collection

Constituents:

Publisher: W. G. MacFarlane Publishing Co. Ltd. Toronto

Photographer: Unknown

Constituents Note: The W. G. MacFarlane Publishing Co. Ltd. Toronto maintained offices in Toronto commencing in1899 and published postcards between 1902 and 1910.

Title: Bay Front of Island Park, Toronto Title Note: Printed

Date(s) of Object: 1908

Date Notes: The card is postmarked

August 11, 1908

Object Name: Postcard

Medium: Collotype

Dimensions:

Image: $8.9 \times 13.7 \mathrm{~cm}, 3.50 \times 5.39$ in

Sheet: $8.9 \times 13.7 \mathrm{~cm}, 3.50 \times 5.39$ in

Geography:

Place Created: Toronto

Place Depicted: Looking north towards Blockhouse Bay, Lakeshore Avenue is visible on the left while a western portion of Centre Island is visible on the right

Mark(s): recto: titled; verso: publisher imprint, post template, [no.] E. 181 l.r.

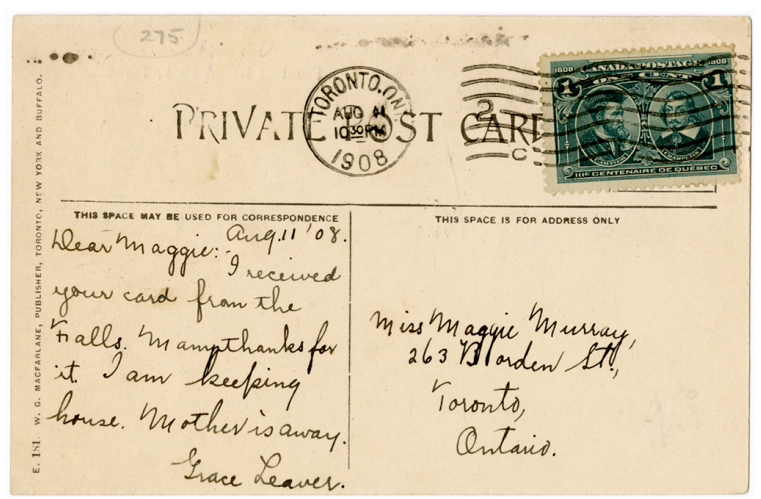

Verso

Inscriptions: verso: in ink: Aug 11 '08 Dear Maggie I received your card from the Falls. Many thanks for it. I am keeping house. Mother is away. Grace Leaver. Miss Maggie Murray 263 Borden Street., Toronto, Ontario., [no.] 275 [circled] t.l. Notes: As early as 1881 the City of Toronto Council undertook improvements of Centre Island including the construction of the City Wharf, new plank sidewalks, the dredging and filling of ponds. In 1887, Parks Superintendent John Chambers undertook the implementation of an ambitious plan for the improvement of Island Park. Island Park was opened to the public in July and August of 1888.

Alternate Number: AGO.98696 


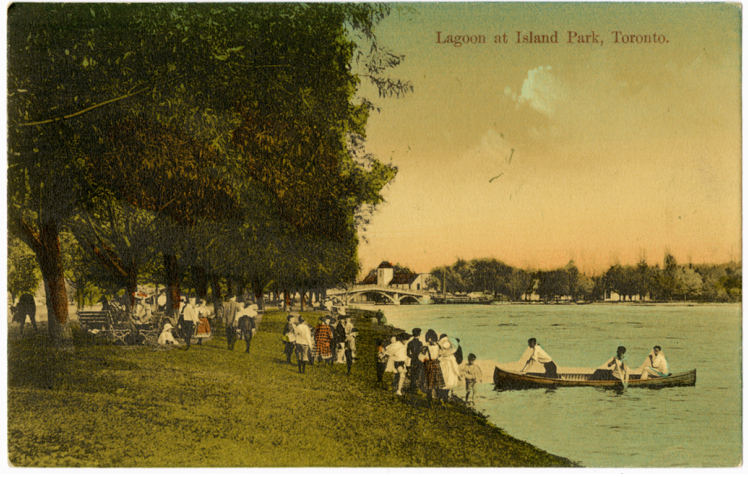

Recto

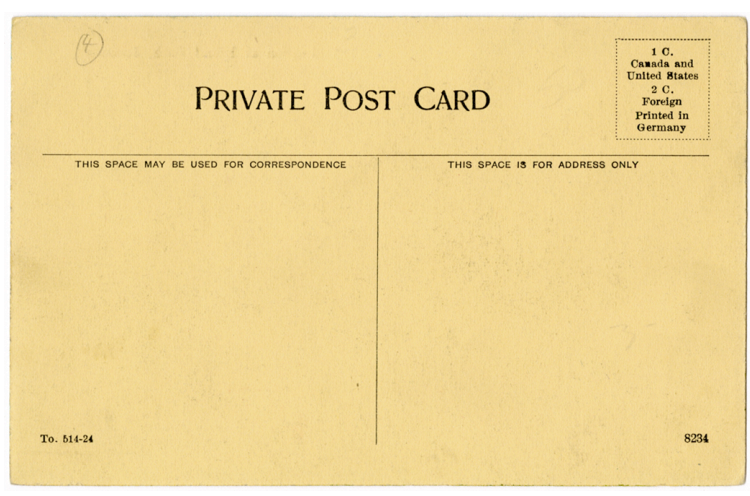

Verso

AG0 Accession Number: 2011/232

Classification: Photography Collection

Constituents:

Publisher: Unknown

Photographer: Unknown

Constituents Note: None

Title: Lagoon at Island Park, Toronto

Title Note: Printed

Date(s) of Object: [after 1912]

Date Notes: Manitou Road Bridge was

constructed in 1912.

Object Name: Postcard

Medium: Collotype

Dimensions:

Image: $8.8 \times 13.9 \mathrm{~cm}, 3.46 \times 5.47 \mathrm{in}$

Sheet: $8.8 \times 13.9 \mathrm{~cm}, 3.46 \times 5.47 \mathrm{in}$

Geography:

Place Created: Germany

Place Depicted: A view looking east toward Manitou Road Bridge

Mark(s): recto: titled; verso: post

template, [no.] To. 514-24 1.l., [no.] 8234

l.r.

Inscriptions: verso: in graphite: [no.] 4 [circled] t.l.

Notes: In 1887, Parks Superintendent John Chambers implemented an ambitious plan for the improvement of Island Park. Island Park was opened to the public in July and August of 1888. In the distance is the Manitou Road Bridge constructed in 1912 to connect Island Park and Centre Island. Long Pond lagoon is visible on the right.

Alternate Number: AG0.98697 


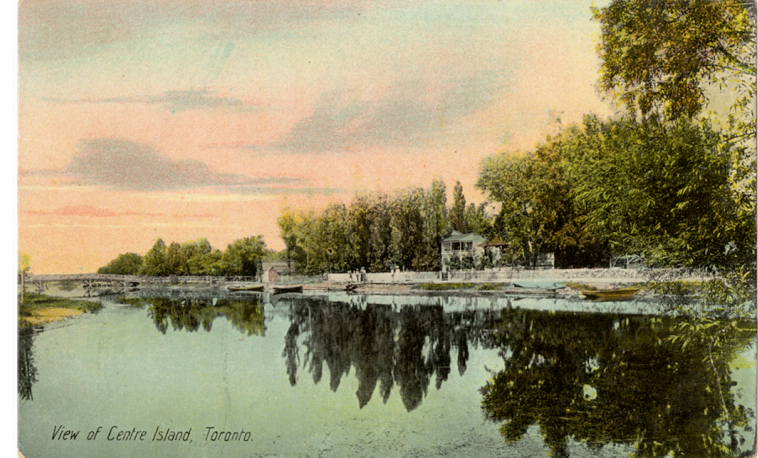

Recto

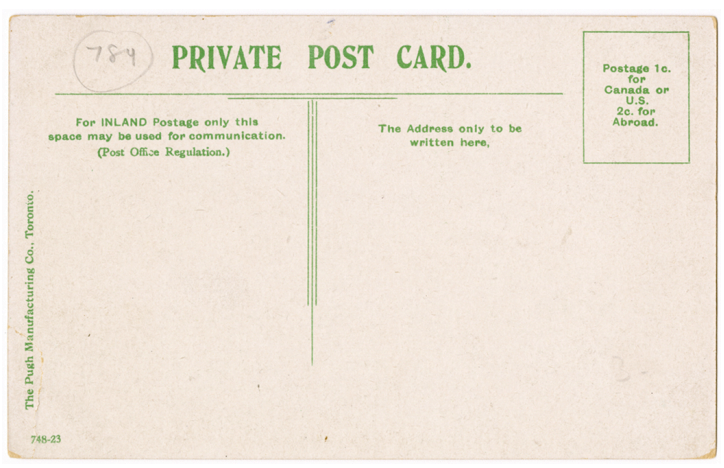

Verso

AGO Accession Number: 2011/233

Classification: Photography Collection

\section{Constituents:}

Publisher: The Pugh Manufacturing Co.

Photographer: Unknown

Constituents Note: None

Title: View of Centre Island, Toronto

Title Note: Printed

Date(s) of Object: ca1910

Date Notes: None

Object Name: Postcard

Medium: Rotogravure

Dimensions:

Image: $8.7 \times 13.9 \mathrm{~cm}, 3.43 \times 5.47$ in

Sheet: $8.7 \times 13.9 \mathrm{~cm}, 3.43 \times 5.47$ in

Geography:

Place Created: Unknown

Place Depicted: A view looking east towards the bridge connecting Algonquin Island with Centre Island Mark(s): recto: titled; verso: publisher imprint, post template, [no.] 748-23 l.l.

Inscriptions: verso: in graphite: [no.] 784 t.l.

Notes: None

Alternate Number: AGO.98698 


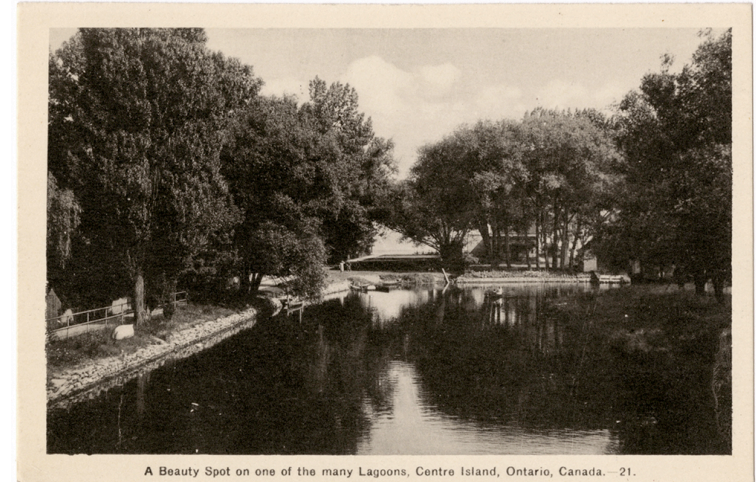

Recto

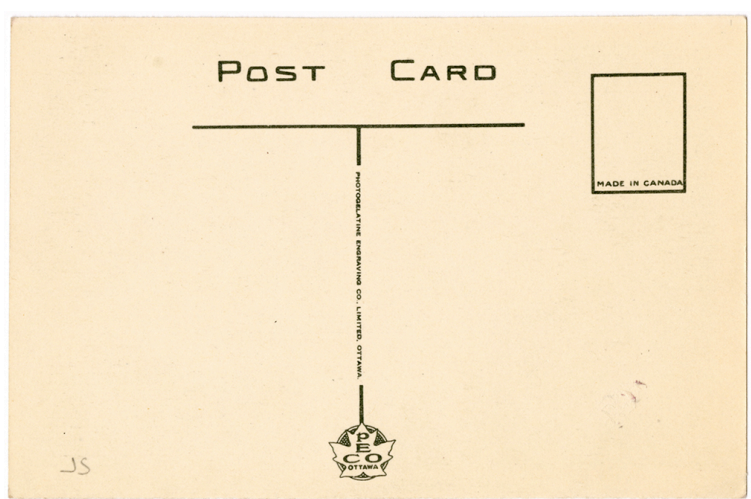

Verso

AGO Accession Number: 2011/234

Classification: Photography Collection Constituents:

Publisher: Photogelatine Engraving Co., Limited, Ottawa

Photographer: Unknown

Constituents Note: The Photogelatine

Engraving Co., Ltd., Ottawa was founded in 1910 and maintained operations until 1953

Title: A Beauty Spot on one of the many Lagoons, Centre Island, Ontario, Canada Title Note: Printed Date(s) of Object: [between 1915 and 1930]

Date Notes: Postcards with a white border were first introduced in 1915 and produced until 1930.

Object Name: Postcard

Medium: Collotype

Dimensions:

Image: $7.8 \times 12.6 \mathrm{~cm}, 3.07 \times 4.96$ in

Sheet: $8.9 \times 13.6 \mathrm{~cm}, 3.50 \times 5.35$ in

Geography:

Place Created: Canada

Place Depicted: A view of a lagoon located on Centre Island

Mark(s): recto: titled, [no.] 21.; verso: publisher imprint, trademark 'PECO OTTAWA'

Inscriptions: verso: in graphite: JS l.l. Notes: None

Alternate Number: AG0.98699 


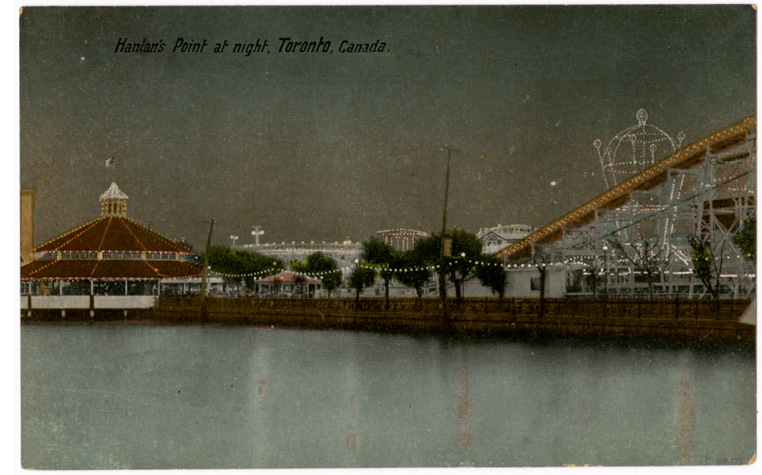

Recto

AGO Accession Number: 2011/235

Classification: Photography Collection

Constituents:

Publisher: The Valentine \& Sons

Publishing Co. Ltd. Montreal and

Toronto

Photographer: Unknown

Constituents Note: The Valentine \& Sons

Publishing Co. Ltd. was founded in

Montreal and Toronto in 1903 and 1906

respectively. Operations were terminated in 1923.

Title: Hanlan's Point at Night, Toronto, Canada

Title Note: Printed

Date(s) of Object: [between 1908 and 1923]

Date Notes: This card was printed after

Valentine \& Sons began to use the 'FAMOUS THROUGHOUT THE WORLD' trademark in 1908 and prior to the ceasing of operations in Toronto in 1923.

Object Name: Postcard

Medium: Rotogravure

Dimensions:

Image: $8.6 \times 13.5 \mathrm{~cm}, 3.39 \times 5.31$ in

Sheet: $8.6 \times 13.5 \mathrm{~cm}, 3.39 \times 5.31 \mathrm{in}$

Geography:

Place Created: Great Britain

Place Depicted: A view Hanlan's Point

Amusement Park taken from the

breakwater

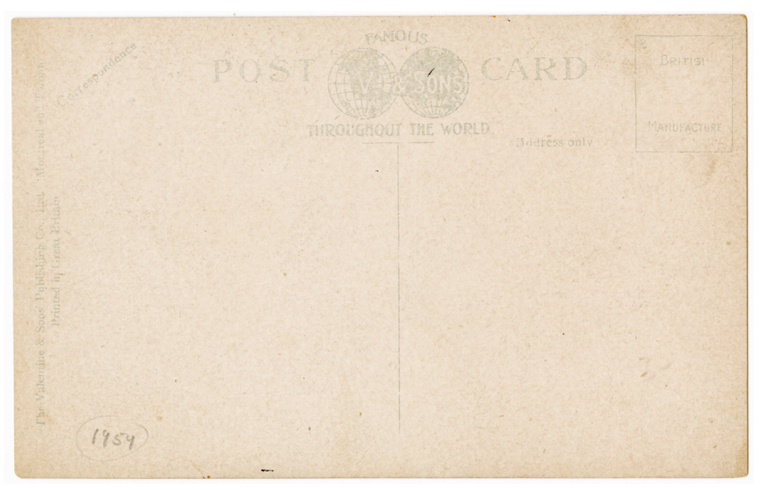

Verso

Mark(s): recto: titled; verso: publisher imprint, trademark, post template Inscriptions: verso: in graphite: [no.] 1959 [circled] l.l.

Notes: The Toronto Ferry Company developed the Hanlan's Point Amusement Park in 1894. Destroyed by fire in 1903 and 1909 the amusement park was rebuilt. The Carousel Building is visible on the left, the Dips Hill lift on the right with the Circle Swing behind the lift. In 1927 the park was purchased by the City of Toronto and operated by the Toronto Transit Commission. The park was finally demolished in 1937.

Alternate Number: AGO.98700 


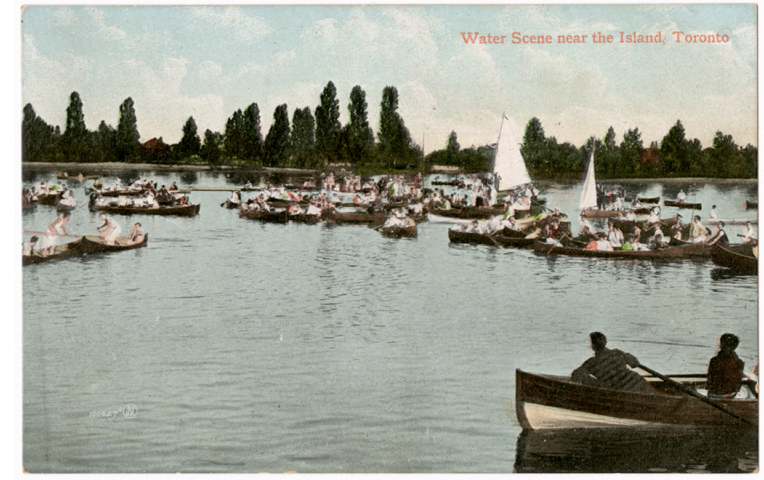

Recto

AGO Accession Number: 2011/236

Classification: Photography Collection

Constituents:

Publisher: The Valentine \& Sons

Publishing Co. Ltd.

Photographer: Unknown

Constituents Note: The Valentine \& Sons

Publishing Co. Ltd. was founded in

Montreal and Toronto in 1903 and 1906

respectively. Operations were terminated in 1923.

Title: Water Scene near the Island,

Toronto

Title Note: Printed

Date(s) of Object: [between 1903 and 1908]

Date Notes: This card was printed prior to when Valentine \& Sons began to use the 'FAMOUS THROUGHOUT THE WORLD' trademark in 1908.

Object Name: Postcard

Medium: Letterpress halftone

Dimensions:

Image: $8.7 \times 13.7 \mathrm{~cm}, 3.43 \times 5.39$ in

Sheet: $8.7 \times 13.7 \mathrm{~cm}, 3.43 \times 5.39$ in

\section{Geography:}

Place Created: Great Britain

Place Depicted: A view Toronto

Harbour looking toward Toronto Islands

\section{SOUVENIR POST GARD}

Verso

Mark(s): recto: titled, [no.] 100827 JV [circled] 1.l.; verso: publisher imprint, trademark 'Souvenir Post Card', post template Inscriptions: verso: in graphite: [no.] 1853 [circled] l.r.

Notes: None

Alternate Number: AG0.98701 


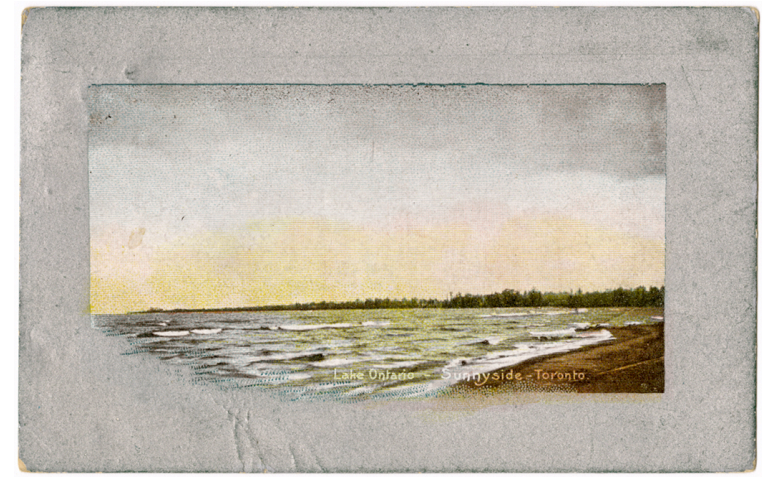

Recto

AG0 Accession Number: 2011/237

Classification: Photography Collection

Constituents:

Publisher: Henry Garner - Living

Picture Post Card Co. (H G L)

Photographer: Unknown

Constituents Note: The Henry Garner -

Living Picture Postcard Co. was located in Leicester England and produced postcards depicting scenes of Toronto.

Title: Lake Ontario - Sunnyside - Toronto

Title Note: Printed

Date(s) of Object: 1908

Date Notes: The card is postmarked July

17, 1908

Object Name: Postcard

Medium: Rotogravure

Dimensions:

Image: $5.9 \times 11 \mathrm{~cm}, 2.32 \times 4.33 \mathrm{in}$

Sheet: $8.8 \times 14 \mathrm{~cm}, 3.46 \times 5.51$ in

Geography:

Place Created: unknown

Place Depicted: View of Humber Bay

west of the Canadian National

Exhibition grounds looking west

Mark(s): recto: titled; verso: HGL

registered trademark, copyright, post

template

Inscriptions: verso: in ink: Wishing you success to-morrow Love from May $\mathrm{H}$. Miss Black "Elms Leigh" Clarens [stroked through] St. Marys Road Victoria Park Road Leicester; in graphite: [no.] 2925 [circled] l.l.

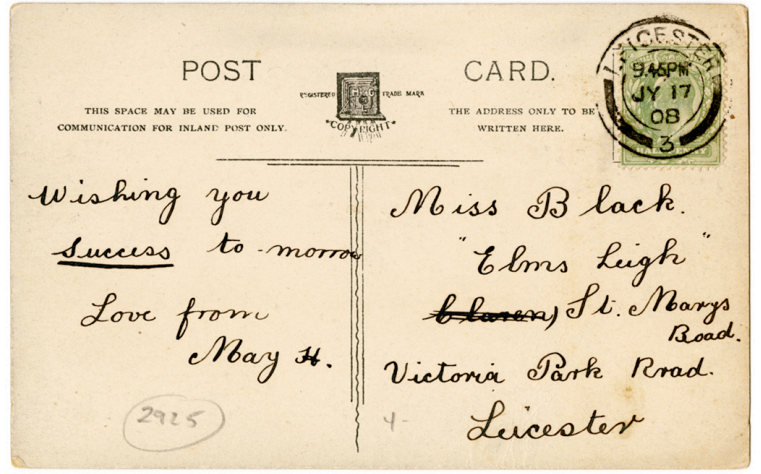

Verso

Notes: Sunnyside is a district located along the lakeshore west of the Exhibition Grounds south of where King Street, Queen Street West and Roncesvalles Avenue intersect. Between 1922 and 1955 the area underwent an extensive waterfront reclamation project undertaken by the Toronto Harbour Commission.

Alternate Number: AG0.98702 


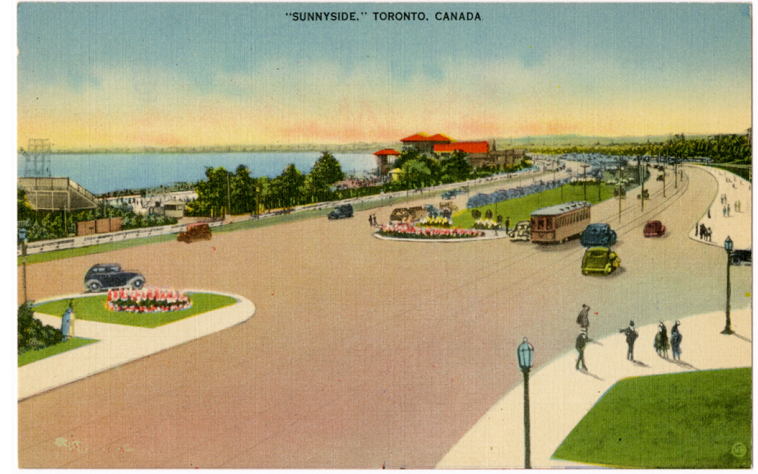

Recto

AG0 Accession Number: 2011/238

Classification: Photography Collection

Constituents:

Publisher: Valentine-Black Co., Ltd.,

Toronto, Canada

Photographer: Unknown

Constituents Note: Valentine-Black Co., Ltd., maintained operations in Toronto from 1922 to 1933.

Title: "SUNNYSIDE," TORONTO, CANADA Title Note: Printed

Date(s) of Object: [between 1930 and 1933]

Date Notes: Postcards exhibiting the 'linen' finish were produced in 1930 and continued to 1945 . The Valentine-Black Co., Ltd ceased operations in 1933

Object Name: Postcard

Medium: Offset lithograph

Dimensions:

Image: $8.8 \times 13.9 \mathrm{~cm}, 3.46 \times 5.47 \mathrm{in}$

Sheet: $8.8 \times 13.9 \mathrm{~cm}, 3.46 \times 5.47 \mathrm{in}$

\section{Geography:}

Place Created: U. S. A.

Place Depicted: A view of Lakeshore

Boulevard West, at the foot of Colborne Lodge Drive

Mark(s): recto: titled, VB [circled]; verso: publisher imprint, Valentine \& Sons trademark, post template, [no.] 114921 l.l. Inscriptions: verso: in graphite: JS l.l.

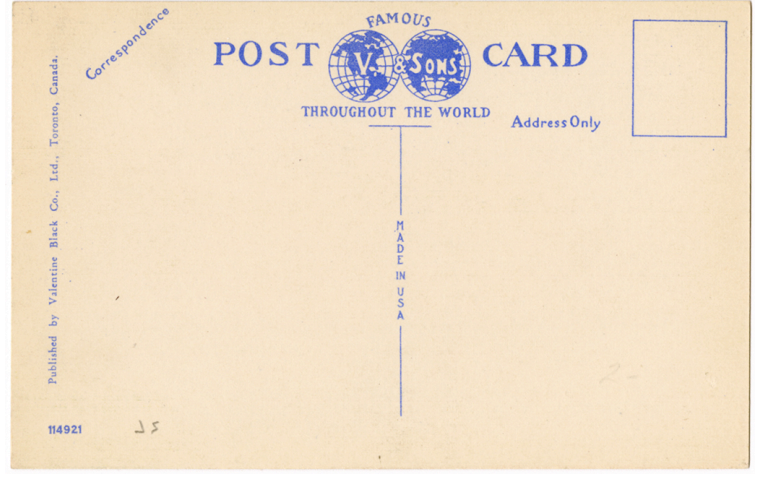

Verso

Notes: Lakeshore Boulevard in the foreground was constructed in 1921. In the distance to the left is the Sunnyside Swimming Pool constructed in 1923. In the distance and to the right is the Sunnyside Bathing Pavilion designed by Alfred Hirschfelder Chapman (18791949), James Morrow Oxley (1883-1957) and Roy Bishop (1888-1948) and constructed in 1922 in the Italianate style. Alternate Number: AG0.98703 


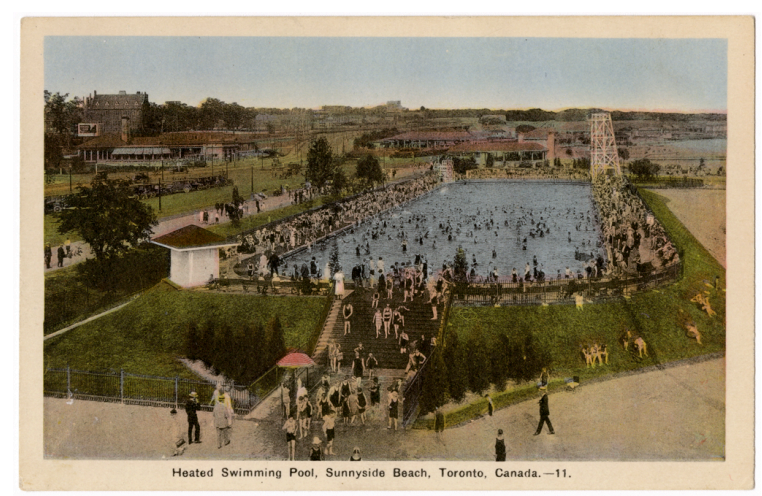

Recto

AGO Accession Number: 2011/239

Classification: Photography Collection Constituents:

Publisher: Photogelatine Engraving Co., Limited, Ottawa

Photographer: Unknown

Constituents Note: The Photogelatine

Engraving Co., Ltd., Ottawa was founded

in 1910 and maintained operations until 1953

Title: Heated Swimming Pool: Sunnyside Beach, Toronto, Canada - 11

Title Note: Printed

Date(s) of Object: [between 1923 and 1930]

Date Notes: The Sunnyside Pool was opened in 1923 and postcards with a white border were first introduced in 1915 and produced until 1930

Object Name: Postcard

Medium: Collotype

Dimensions:

Image: $7.9 \times 12.7 \mathrm{~cm}, 3.11 \times 5.00 \mathrm{in}$

Sheet: $8.9 \times 13.8 \mathrm{~cm}, 3.50 \times 5.43 \mathrm{in}$

Geography:

Place Created: Canada

Place Depicted: Sunnyside Pool located at Lakeshore Boulevard West, at the foot of Colborne Lodge Drive

Mark(s): recto: titled, [no.] 11. l.c.; verso: publisher imprint, trademark 'PECO

OTTAWA'

Inscriptions: verso: in graphite: [no.] 2811 [circled] l.l.

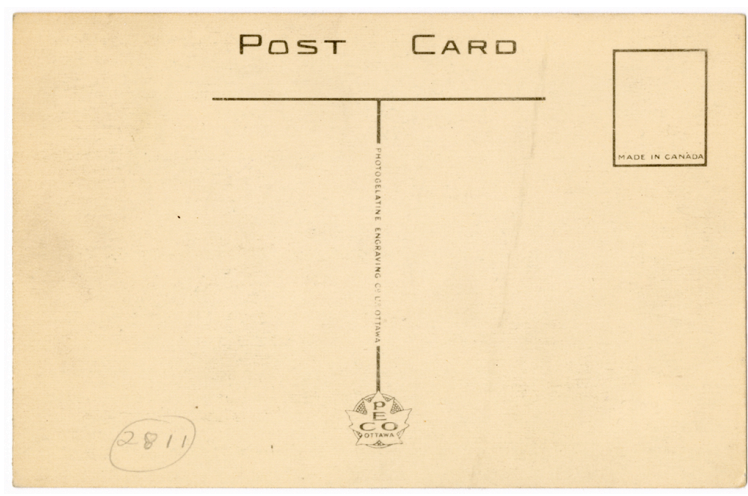

Verso

Notes: The Sunnyside Pool was opened in 1923. In the distance the Palais Royale (originally Dean's Boat House) is visible designed by Alfred Hirschfelder Chapman (1879-1949), James Morrow Oxley (18831957) and Roy Bishop (1888-1948) and constructed in 1922.

Alternate Number: AG0.98704 


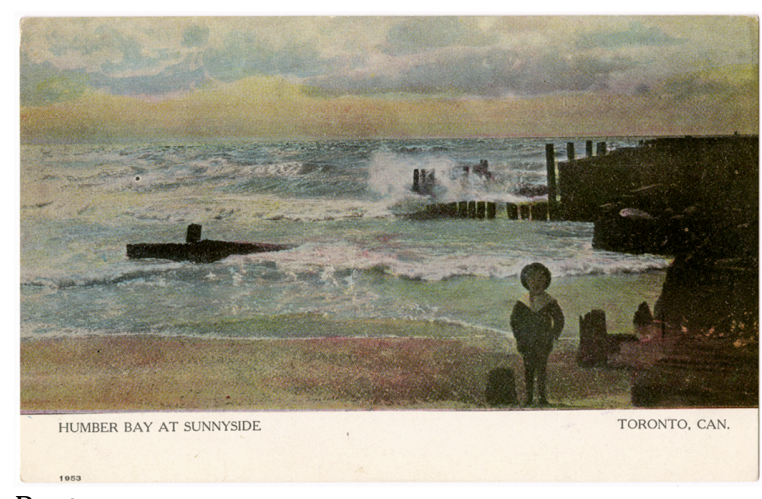

Recto

AGO Accession Number: 2011/240

Classification: Photography Collection

\section{Constituents:}

Publisher: Warwick Bro's \& Rutter, Limited, Publishers, Toronto

Photographer: Unknown

Constituents Note: Warwick Bro's \&

Rutter, Limited maintained operations in

Toronto from 1860 to 1972 and

published postcards between 1903 and

1912

Title: Humber Bay at Sunnyside -

Toronto, Can.

Title Note: Printed

Date(s) of Object: [between 1903 and

1912]

Date Notes: Canadian Postal regulations allowed divided postcards in 1903 and the Warwick Bro's \& Rutter, Limited, Publishers ceased publishing postcards in 1912.

Object Name: Postcard

Medium: Letterpress halftone

Dimensions:

Image: $7.5 \times 14 \mathrm{~cm}, 2.95 \times 5.51$ in

Sheet: $8.8 \times 14 \mathrm{~cm}, 3.46 \times 5.51$ in

Geography:

Place Created: Toronto, Ontario

Place Depicted: A view of Humber Bay west of Sunnyside

Mark(s):recto: titled, [no.] 1953 l.l.;

verso: publishers imprint, trademark

'Canadian Souvenir Post Card', post template

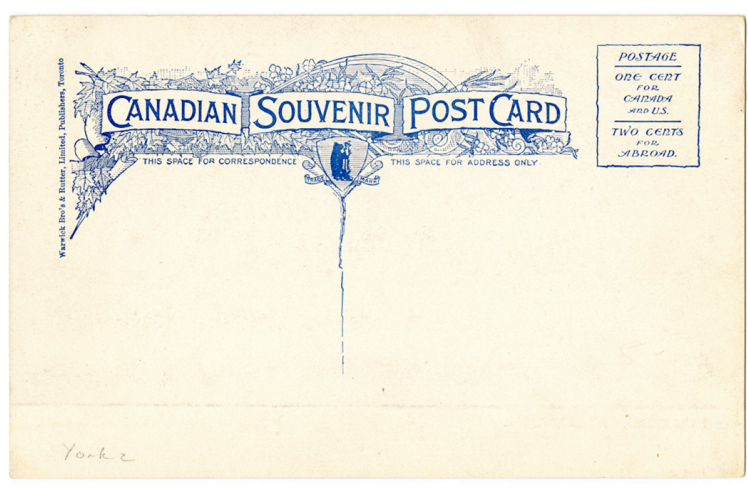

Verso

Inscriptions: verso: in graphite: York 2 l.l.

Notes: Sunnyside is a district located along the lakeshore west of the Exhibition and east along Humber Bay. Humber Bay is situated east of Ontario Place and west of Mimico Creek. The Toronto Harbour Commission undertook a large reclamation project commencing 1922 infilling the bay by 100 yards.

Alternate Number: AGO.98705 


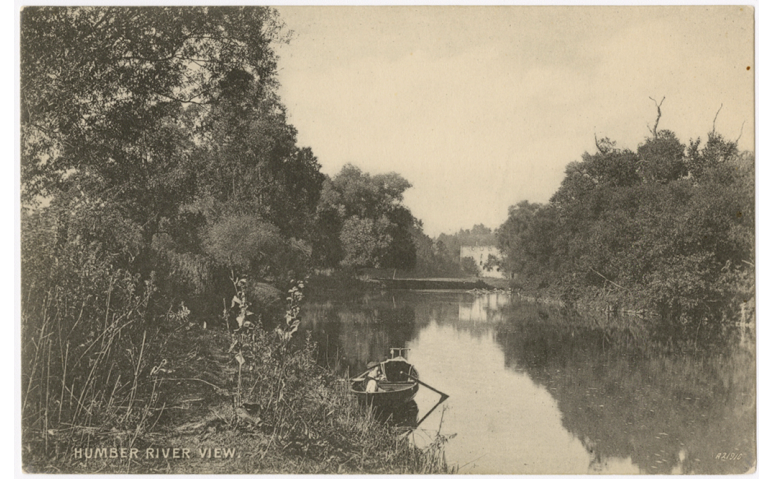

Recto

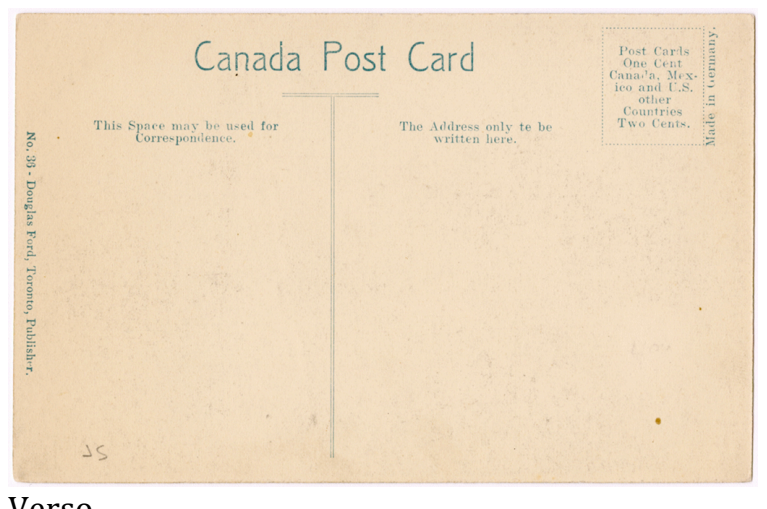

Verso

AG0 Accession Number: 2011/241

Classification: Photography Collection

Constituents:

Publisher: Douglas Ford Toronto,

Publisher

Photographer: Unknown

Constituents Note: Douglas Ford

Toronto Publisher produced postcards

from 1905 to 1906.

Title: Humber River View

Title Note: Printed

Date(s) of Object: [between 1905 and 1906]

Date Notes: None

Object Name: Postcard

Medium: Collotype

Dimensions:

Image: $8.8 \times 13.9 \mathrm{~cm}, 3.46 \times 5.47 \mathrm{in}$

Sheet: $8.8 \times 13.9 \mathrm{~cm}, 3.46 \times 5.47 \mathrm{in}$

Geography:

Place Created: Germany

Place Depicted: A view of the Humber

River looking northwest

Mark(s): recto: titled, publisher imprint, post template, [no.] A21910 l.r.

Inscriptions: verso: in graphite: JS l.l.

Notes: The main branch of the Humber

River flows $100 \mathrm{~km}$ from its source in the Town of Caledon and the Townships of Adjala-Tosorontio and Mono to Lake Ontario between the cities of Etobicoke and the City of Toronto.

Alternate Number: AG0.98706 


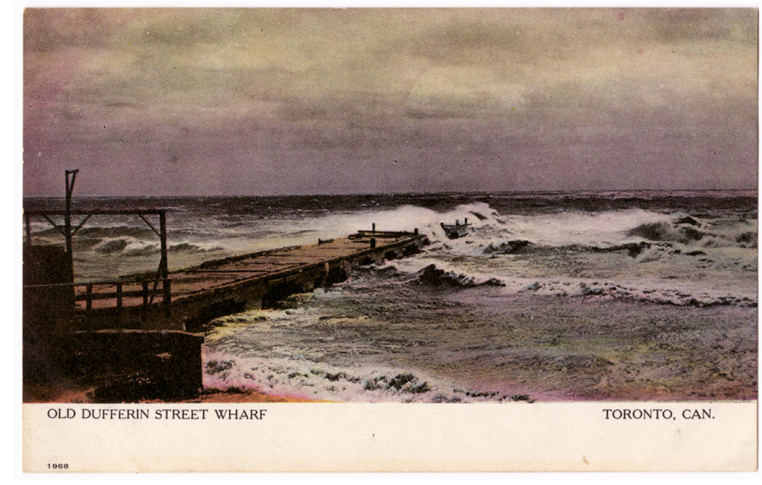

Recto

AGO Accession Number: 2011/242

Classification: Photography Collection

Constituents:

Publisher: Warwick Bro's \& Rutter, Limited, Publishers, Toronto

Photographer: Unknown

Constituents Note: Warwick Bro's \&

Rutter, Limited maintained operations in

Toronto from 1860 to 1972 and

published postcards between 1903 and

1912

Title: Old Dufferin Street Wharf -

Toronto, Can.

Title Note: Printed

Date(s) of Object: [between 1903 and 1912]

Date Notes: Canadian Postal regulations allowed divided postcards in 1903.

Warwick Bro's \& Rutter, Limited, Publishers produced postcards from 1903 to 1912.

Object Name: Postcard

Medium: Letterpress halftone

Dimensions:

Image: $7.5 \times 13.9 \mathrm{~cm}, 2.95 \times 5.47 \mathrm{in}$

Sheet: $8.8 \times 13.9 \mathrm{~cm}, 3.46 \times 5.47 \mathrm{in}$

\section{Geography:}

Place Created: Toronto, Ontario

Place Depicted: The Humber Bay terminus of Dufferin Street

Mark(s):recto: titled, [no.] 1968 1.l.; verso: publishers imprint, trademark 'Canadian Souvenir Post Card', post template

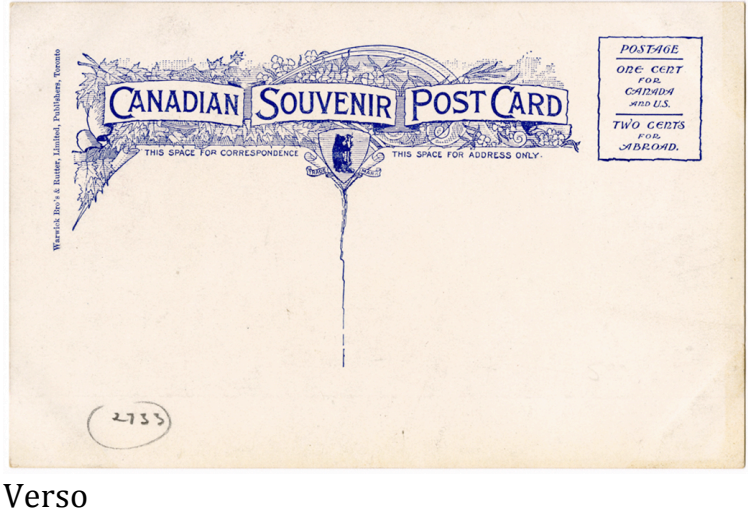

Verso

Inscriptions: verso: in graphite: [no.] 2733 [circled] 1.l.

Notes: One of fifteen wharves located along the central Toronto waterfront at the foot of Dufferin Street. Dufferin Street was named after Lord Dufferin, Frederick Temple Blackwood (1826-1902).

Alternate Number: AG0.98707 


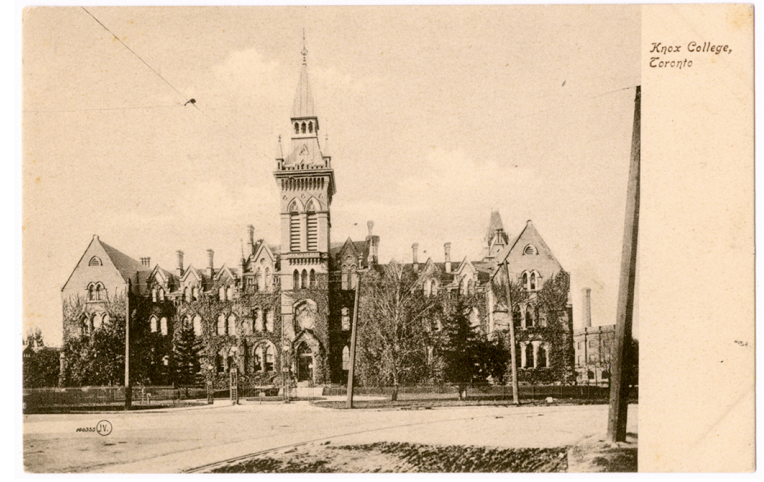

Recto

AGO Accession Number: 2011/243

Classification: Photography Collection

Constituents:

Publisher: Valentine \& Sons Ltd.,

Toronto and Montreal

Photographer: Unknown

Constituents Note: The Valentine \& Sons

Publishing Co. Ltd. was founded in

Montreal and Toronto in 1903 and 1906

respectively. Operations were terminated in 1923.

Title: Knox College, Toronto

Title Note: Printed

Date(s) of Object: [between 1903 and 1908]

Date Notes: This card was printed prior to when the company began to use the 'FAMOUS THROUGHOUT THE WORLD' trademark in 1908.

Object Name: Postcard

Medium: Collotype

Dimensions:

Image: $8.8 \times 11.6 \mathrm{~cm}, 3.46 \times 4.57$ in

Sheet: $8.8 \times 13.8 \mathrm{~cm}, 3.46 \times 5.43 \mathrm{in}$

Geography:

Place Created: Scotland

Place Depicted: 1 Spadina Crescent,

Toronto, Ontario

Mark(s): recto: titled, [no.] 100355 JV

[circled] l.l.; verso: publisher imprint, post

template

Inscriptions: verso: in graphite: not

common [with an arrow] t.r.

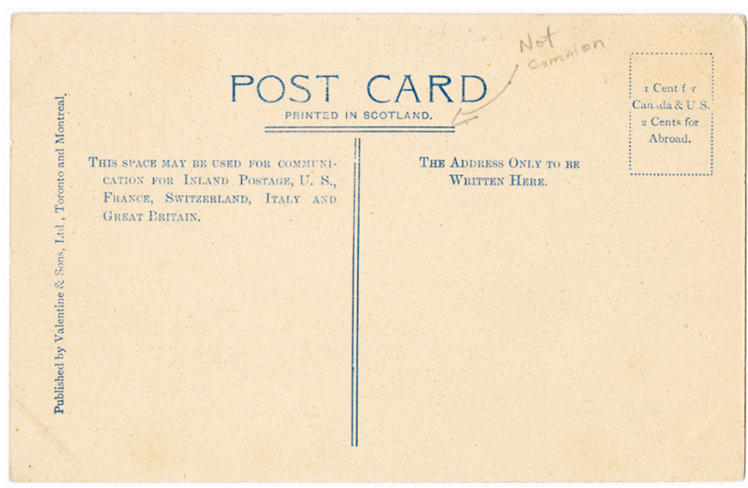

Verso

Notes: Designed by architects James Avon Smith (1832-1918) and John Gemmell (1851-1915) in the Gothic-Revival style and constructed in 1873-75.

Alternate Number: AG0.98708 


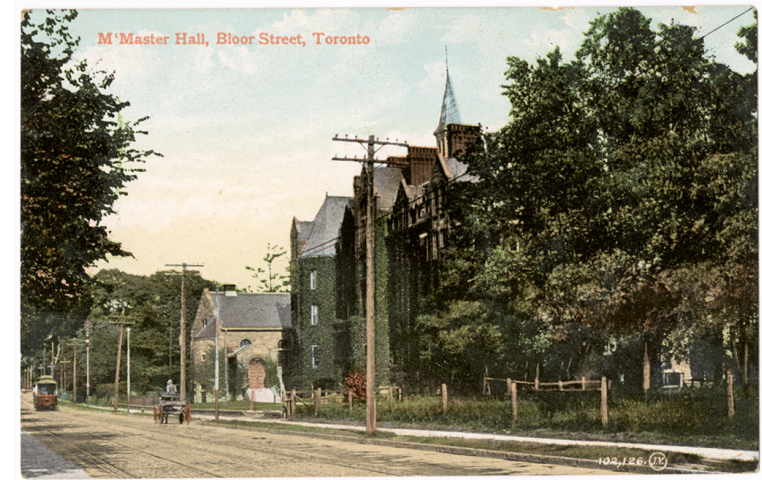

Recto

AGO Accession Number: 2011/244

Classification: Photography Collection

Constituents:

Publisher: The Valentine \& Sons Co.

Ltd., Montreal and Toronto

Photographer: Unknown

Constituents Note: The Valentine \& Sons

Publishing Co. Ltd. was founded in

Montreal and Toronto in 1903 and 1906

respectively. Operations were terminated in 1923.

Title: McMaster Hall, Bloor Street,

Toronto

Title Note: Printed

Date(s) of Object: [between 1903 and 1908]

Date Notes: This card was printed prior to when the company began to use the 'FAMOUS THROUGHOUT THE WORLD' trademark in 1908.

Object Name: Postcard

Medium: Letterpress halftone

Dimensions:

Image: $8.7 \times 13.6 \mathrm{~cm}, 3.43 \times 5.35$ in

Sheet: $8.7 \times 13.6 \mathrm{~cm}, 3.43 \times 5.35 \mathrm{in}$

\section{Geography:}

Place Created: Great Britain

Place Depicted: 273 Bloor Street West,

Toronto, Ontario

Mark(s): recto: titled, [no.] 102,126 JV

[circled] l.r.; verso: publisher imprint, post template,

Inscriptions: verso: in graphite: 2378

[circled] l.r.

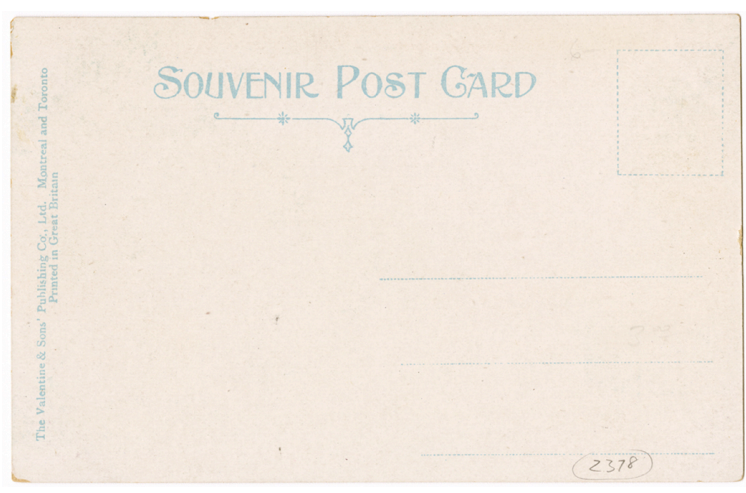

Verso

Notes: Designed by architect Edmund Burke (1850-1919) McMaster Hall (McMaster University) was constructed in 1899-90. The university relocated to Hamilton, Ontario in 1930. The building was sold to the University of Toronto and now is the site of the Royal Conservatory of Music.

Alternate Number: AG0.98709 


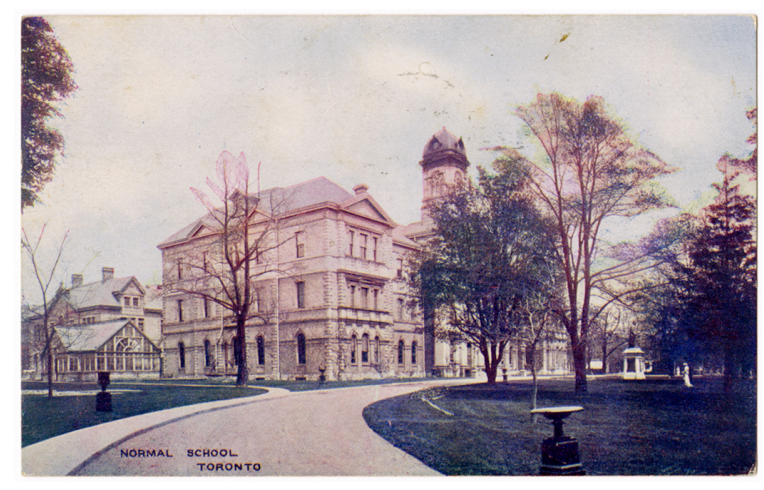

Recto

AGO Accession Number: 2011/245

Classification: Photography Collection Constituents

Publisher: The Canadian View Card Co.

Toronto

Photographer: Alexander W. Galbraith Constituent Note: The Canadian View

Card Co. published postcards at the beginning of the twentieth century in Toronto. Alexander W. Galbraith (18671950) was a commercial photographer in Toronto from 1899 to 1924.

Title: Normal School, Toronto

Title Note: Printed

Date(s) of Object: 1906

Date Notes: This card is postmarked October 14, 1906.

Object Name: Postcard

Medium: letterpress halftone

Dimensions

Image: $8.6 \times 13.7 \mathrm{~cm}, 3.375 \times 5.375$ in

Sheet: $8.6 \times 13.7 \mathrm{~cm}, 3.375 \times 5.375$ in

\section{Geography:}

Place Created: Unknown

Place Depicted: St. James Square

opposite Bond Street, Toronto, Ontario

Mark(s): Recto: titled, Verso: publisher imprint, trademark 'PRIVATE-POST-

CARD', post template

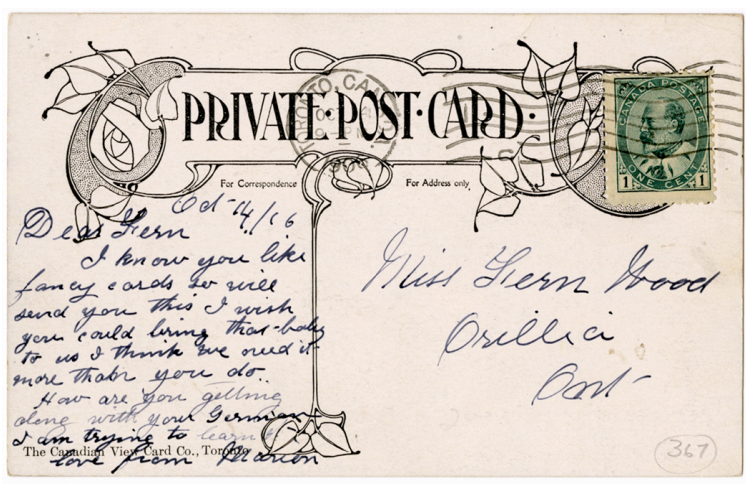

Verso

Inscriptions: verso: in ink: Dear Fern I know you like fancy cards so will send you this I wish you could bring that baby to us I think we need it more than you do How are you getting along with your German I am trying to learn Love from Marion Miss Fern Wood Orillia Ont; in graphite [no.] 367 [circled] l.r.

Notes: Designed by architects Frederic William Cumberland (1820-1881) and Thomas Ridout (1828-1905) combining Palladian, Gothic and Renaissance Revival styles the Normal School was constructed between 1851 and 1852 and demolished in 1963.

Alternate Number: AG0.98710 


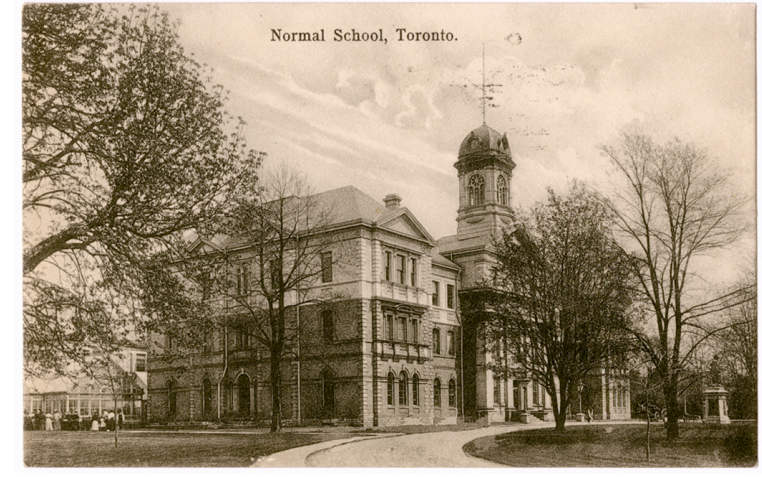

Recto

AG0 Accession Number: 2011/246

Classification: Photography Collection

Constituents:

Publisher: W. G. MacFarlane Publishing Co. Ltd. Toronto

Photographer: Unknown

Constituent Note: The W. G. MacFarlane Publishing Co. Ltd. Toronto maintained offices in Toronto commencing in 1899 and published postcards between 1902 and 1910.

Title: Normal School, Toronto

Title Note: Printed

Date(s) of Object: 1908

Date Notes: postmarked December 18, 1908

Object Name: Postcard

Medium: Collotype

Medium Note:

Dimensions:

Image: $8.7 \times 13.7 \mathrm{~cm}, 3.43 \times 5.39$ in

Sheet: $8.7 \times 13.7 \mathrm{~cm}, 3.43 \times 5.39$ in

\section{Geography:}

Place Created: Toronto, Ontario

Place Depicted: St. James Square opposite Bond Street, Toronto, Ontario Mark(s): recto: titled, verso: publishers imprint, trademark 'Canadian Souvenir Cards', [no.] D. 206. l.l.

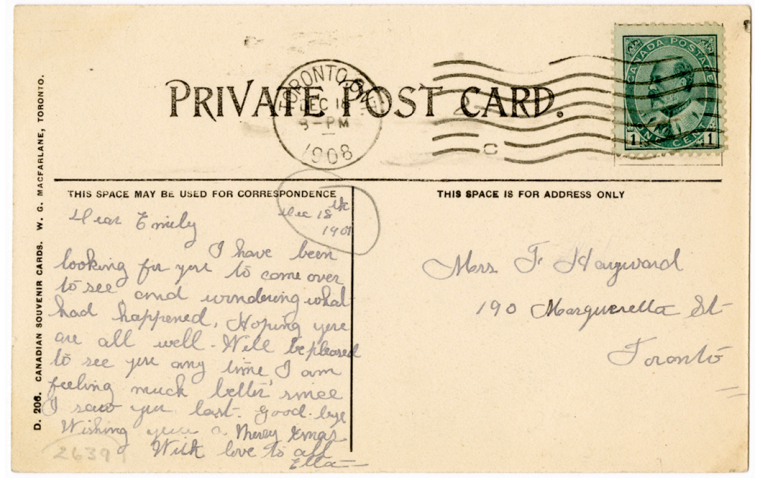

Verso

Inscriptions: verso: in ink: Dec 18th 1907 [circled] Dear Emily I have been looking for you to come over to see and wondering what had happened. Hoping you are all well. Will be pleased to see you any time. I am feeling much better since I saw you last. Good-bye Wishing you a Merry Xmas With love to all Ella Mrs. F. Haywood 190 Margueretta St Toronto; in graphite: [no.] 2639 [circled] 1.l.

Notes: Designed by architects Frederic William Cumberland (1820-1881) and Thomas Ridout (1828-1905) combining Palladian, Gothic and Renaissance Revival styles the Normal School was constructed between 1851 and 1852 and demolished in 1963.

Alternate Number: AG0.98711 


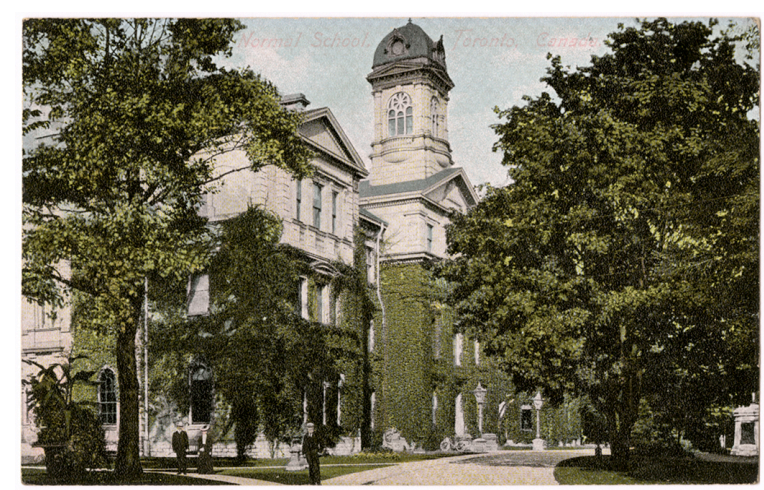

Recto

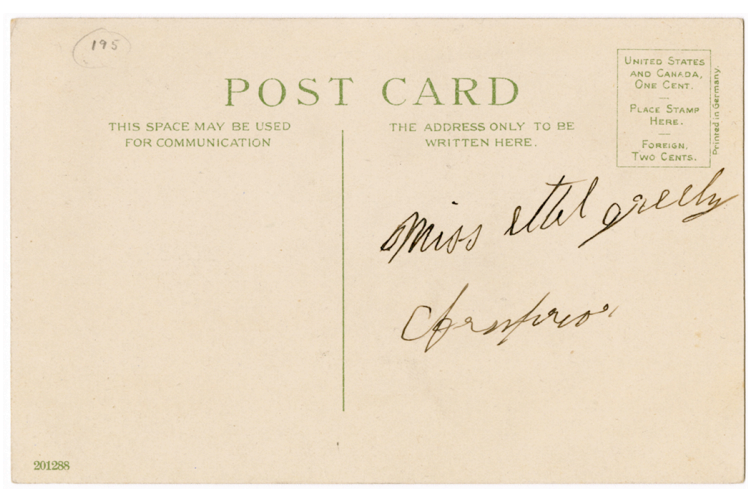

Verso

AG0 Accession Number: 2011/247

Classification: Photography Collection

Constituents:

Publisher: Unknown

Photographer: Unknown

Constituent Note: None

Title: Normal School, Toronto, Canada

Title Note: Printed

Date(s) of Object: [1920s]

Date Notes: None

Object Name: Postcard

Medium: Letterpress halftone

Dimensions:

Image: $8.8 \times 13.9 \mathrm{~cm}, 3.46 \times 5.47 \mathrm{in}$

Sheet: $8.8 \times 13.9 \mathrm{~cm}, 3.46 \times 5.47 \mathrm{in}$

Geography:

Place Created: Unknown

Place Depicted: St. James Square

opposite Bond Street, Toronto, Ontario

Mark(s): recto: titled; verso: post

template, [no.] 201288 l.l.

Inscriptions: verso: in ink: Miss ethel greely [unreadable]

Notes: Designed by architects Frederic

William Cumberland (1820-1881) and

Thomas Ridout (1828-1905) combining

Palladian, Gothic and Renaissance Revival styles the Normal School was constructed between 1851 and 1852 and demolished in 1963.

Alternate Number: AG0.98712 


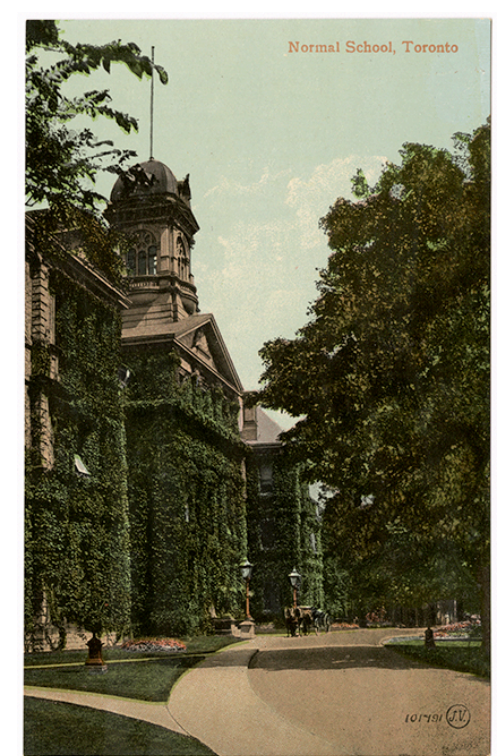

Recto

AGO Accession Number: 2011/248 Classification: Photography Collection Constituents:

Publisher: The Valentine \& Sons Co. Ltd., Montreal and Toronto

Photographer: Unknown Constituents Note: The Valentine \& Sons Publishing Co. Ltd. was founded in Montreal and Toronto in 1903 and 1906 respectively. Operations were terminated in 1923.

Title: Normal School, Toronto

Title Note: Printed

Date(s) of Object: [between 1903 and 1908]

Date Notes: This card was printed prior to when the company began to use the 'FAMOUS THROUGHOUT THE WORLD' trademark in 1908.

Object Name: Postcard

Medium: Letterpress halftone

Dimensions:

Image: $13.8 \times 8.7 \mathrm{~cm}, 5.43 \times 3.43$ in

Sheet: $13.8 \times 8.7 \mathrm{~cm}, 5.43 \times 3.43$ in

\section{Geography:}

Place Created: Great Britain

Place Depicted: St. James Square opposite Bond Street, Toronto, Ontario

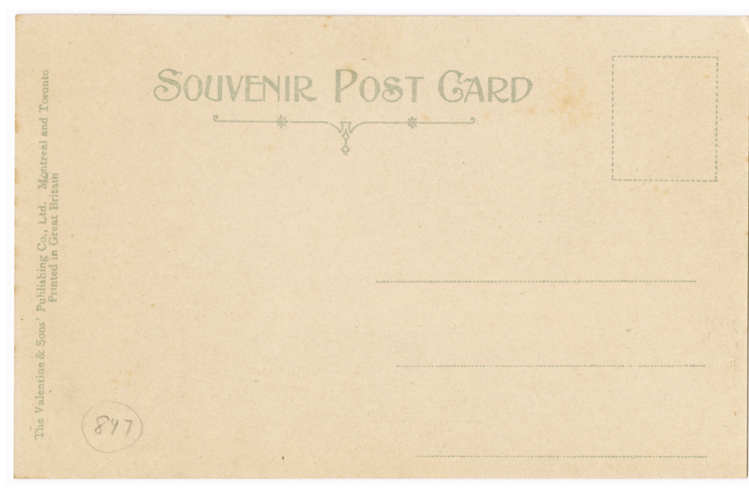

Verso

Mark(s): recto: titled, [no.] $101791 \mathrm{JV}$ [circled] l.r.; verso: publisher imprint, post template,

Inscriptions: verso: in graphite: 847 [circled] l.l.

Notes: Designed by architects Frederic William Cumberland (1820-1881) and Thomas Ridout (1828-1905) combining Palladian, Gothic and Renaissance Revival styles the Normal School was constructed between 1851 and 1852 and demolished in 1963.

Alternate Number: AG0.98713 


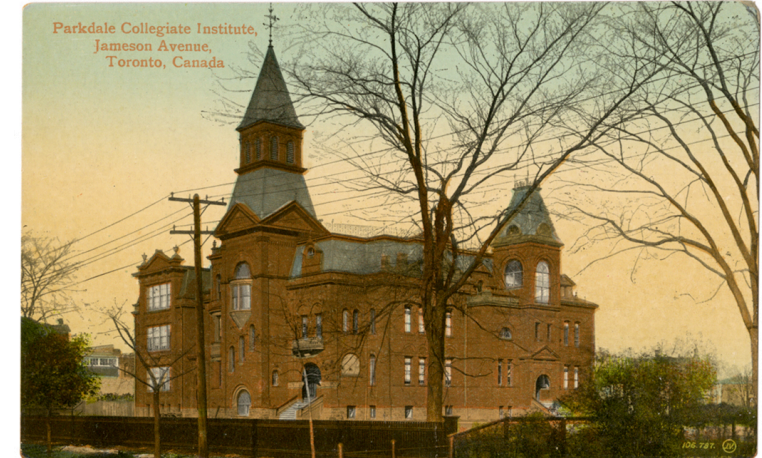

Recto

AGO Accession Number: 2011/249

Classification: Photography Collection Constituents:

Publisher: The Valentine \& Sons Co. Ltd., Montreal and Toronto

Photographer: Unknown

Constituents Note: The Valentine \& Sons

Publishing Co. Ltd. was founded in Montreal and Toronto in 1903 and 1906 respectively. Operations were terminated in 1923.

Title: Parkdale Collegiate Institute, Jameson Avenue, Toronto, Canada

Title Note: Printed

Date(s) of Object: [between 1908 and 1923]

Date Notes: The Jameson Collegiate was renamed the Parkdale Collegiate Institute in 1908. This card was printed after the Valentine \& Sons began to use the 'FAMOUS THROUGHOUT THE WORLD' trademark in 1908.

Object Name: Postcard

Medium: Rotogravure

Dimensions:

Image: $8.6 \times 13.8 \mathrm{~cm}, 3.39 \times 5.43 \mathrm{in}$

Sheet: $8.6 \times 13.8 \mathrm{~cm}, 3.39 \times 5.43$ in

\section{Geography:}

Place Created: Great Britain

Place Depicted: Jameson Avenue,

Toronto, Ontario

Mark(s): recto: titled, [no.] 106,787 JV

[circled] l.r.; verso: publisher imprint, trademark, post template

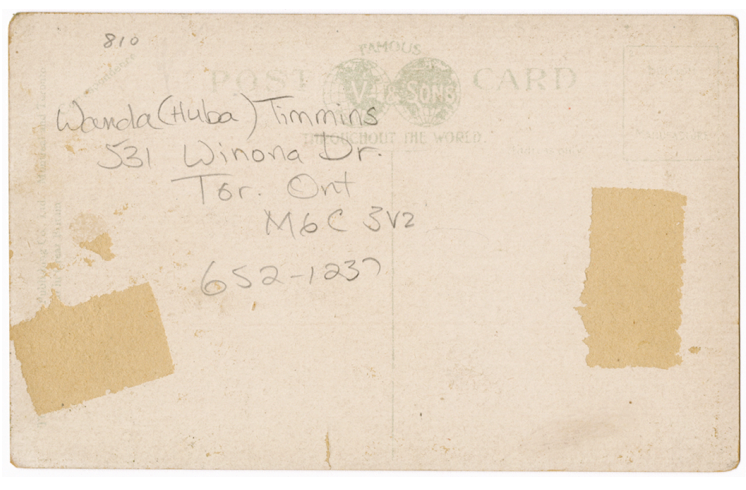

Verso

Inscriptions: verso: in ink: Wanda (Huba) Timmins 531 Winona Dr. Tor. Ont M6C 3V2 652-121237; in graphite: [no.] 810 t.l.

Notes: Designed by George Martel Miller (1854-1933) and constructed in 1888, the Parkdale Collegiate Institute was demolished in 1928.

Alternate Number: AGO.98714 


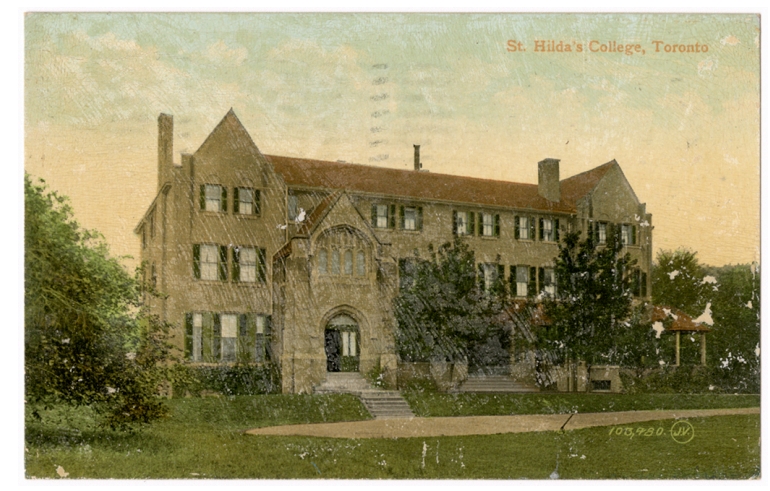

Recto

AGO Accession Number: 2011/250

Classification: Photography Collection Constituents:

Publisher: The Valentine \& Sons Co. Ltd., Montreal and Toronto

Photographer: Unknown

Constituents Note: The Valentine \& Sons Publishing Co. Ltd. was founded in Montreal and Toronto in 1903 and 1906 respectively. Operations were terminated in 1923.

Title: St. Hilda's College, Toronto Title Note: Printed Date(s) of Object: [between 1903 and 1908]

Date Notes: The postcard is postmarked August 19, 1908 and was printed prior to when the Valentine \& Sons began to use the 'FAMOUS THROUGHOUT THE WORLD' trademark in 1908.

Object Name: Postcard

Medium: Rotogravure

Dimensions:

Image: $8.7 \times 13.7 \mathrm{~cm}, 3.43 \times 5.39$ in

Sheet: $8.7 \times 13.7 \mathrm{~cm}, 3.43 \times 5.39$ in

Geography:

Place Created: Great Britain

Place Depicted: Northwest corner of

Trinity Bellwoods Park just east of

Crawford Street

Mark(s): recto: titled, [no.] 103,480 JV

[circled] l.r.; verso: publisher imprint, post template,

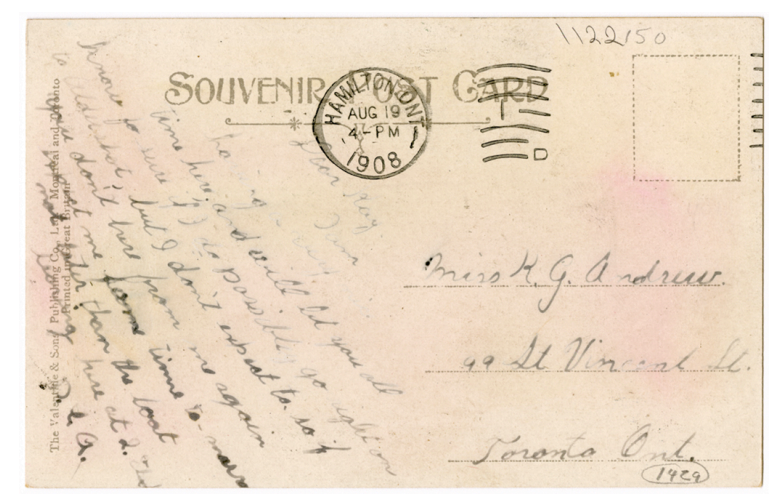

Verso

Inscriptions: verso: in ink: Dear Kay I am having a busy (?) time here and will let you all know for sure if I do possibly go right on to Aldershot, but I don't expect to, so if you don't hear from me again expect me some time to-morrow not later than the boat leaving here at 2. D. \& A. Miss K. G. Andrew 99 St. Vincent St Toronto Ont., [no] 1122150 t.r.; in graphite: [no] 1429 [circled] l.r. Notes: Designed by architect Eden Smith (1858-1949) and constructed in 1899. St. Hilda's College was relocated to the University of Toronto's Queen's Park campus in 1925. The building then became a home for men in 1926 named Strachan House.

Alternate Number: Ago.98715 


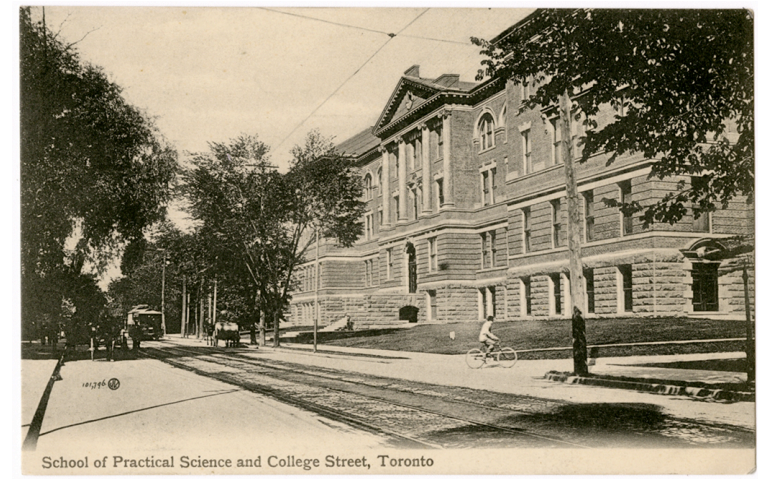

Recto

AGO Accession Number: 2011/251

Classification: Photography Collection

Constituents:

Publisher: Valentine \& Sons Co. Ltd., Montreal and Toronto

Photographer: Unknown

Constituents Note: The Valentine \& Sons

Publishing Co. Ltd. was founded in

Montreal and Toronto in 1903 and 1906

respectively. Operations were terminated in 1923.

Title: School of Practical Science and College Street, Toronto

Title Note: Printed

Date(s) of Object: [between 1903 and 1908]

Date Notes: This card was printed prior to when the company began to use the 'FAMOUS THROUGHOUT THE WORLD' trademark in 1908.

Object Name: Postcard

Medium: Collotype

Dimensions:

Image: $8.2 \times 13.7 \mathrm{~cm}, 3.23 \times 5.39$ in

Sheet: $8.7 \times 13.7 \mathrm{~cm}, 3.23 \times 5.39$ in

Geography:

Place Created: Great Britain

Place Depicted: A view from University

Avenue looking west along College

Street

Mark(s): recto: titled, [no.] 101,796 JV

[circled] 1.l.; verso: publisher imprint, trademark, post template,

Inscriptions: verso: unreadable name (?)

t.r.

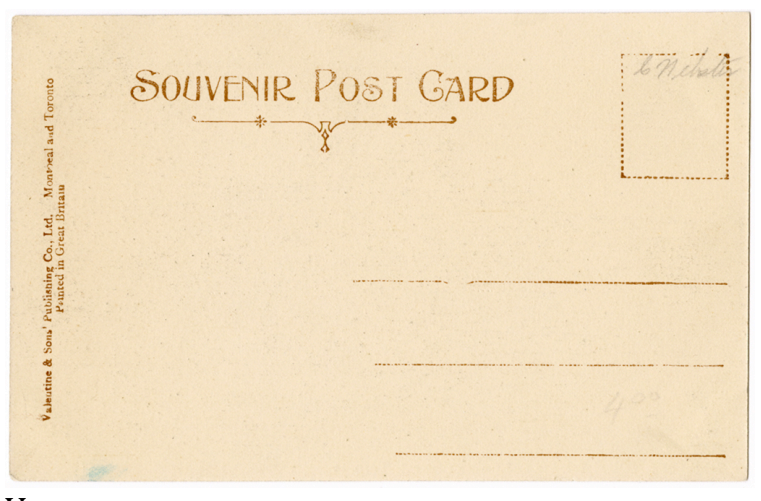

Verso

Notes: Designed by architect Kivas Tully and constructed in 1877 with additions in 1889-90. The building was demolished in 1964. The school was renamed the Faculty of Applied Science and Engineering when it became part of the University of Toronto in 1906.

Alternate Number: AG0.98716 


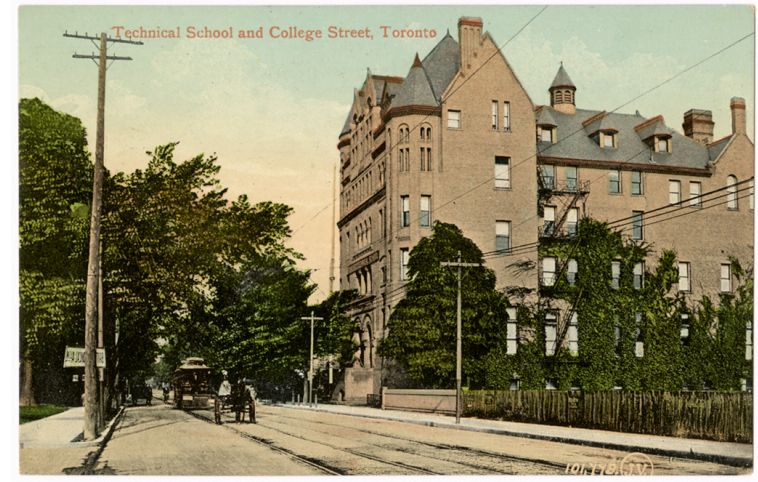

Recto

AG0 Accession Number: 2011/252

Classification: Photography Collection Constituents:

Publisher: Valentine \& Sons Co. Ltd., Montreal and Toronto

Photographer: Unknown

Constituents Note: The Valentine \& Sons Publishing Co. Ltd. was founded in Montreal and Toronto in 1903 and 1906 respectively. Operations were terminated in 1923.

Title: Technical School and College Street, Toronto

Title Note: Printed

Date(s) of Object: [between 1903 and 1908]

Date Notes: This card was printed prior to when the company began to use the 'FAMOUS THROUGHOUT THE WORLD' trademark in 1908.

Object Name: Postcard

Medium: Letterpress halftone

Dimensions:

Image: $8.7 \times 13.6 \mathrm{~cm}, 3.43 \times 5.35$ in

Sheet: $8.7 \times 13.6 \mathrm{~cm}, 3.43 \times 5.35$ in

Geography:

Place Created: Great Britain

Place Depicted: 149 College Street,

Toronto, Ontario west of University

Avenue on the south side of College

Street

Mark(s): recto: titled, [no.] 101,778 JV

[circled] l.r.; verso: publisher imprint, trademark, post template

\section{SOUVENIR POST GARD}

Verso

Inscriptions: verso: in graphite: 4.00 l.r., squiggly line l.r.

Notes: Originally the home for the Toronto Athletic Club the building was designed by Edward James Lennox (18551933) and constructed in 1891-92 in the "Richardson Romanesque" style. Designed by Alexander Frank Wickson (1861-1936) the conversion of the building for the Technical School was undertaken in 1900. The building is now known as the Stewart Building.

Alternate Number: AG0.98717 


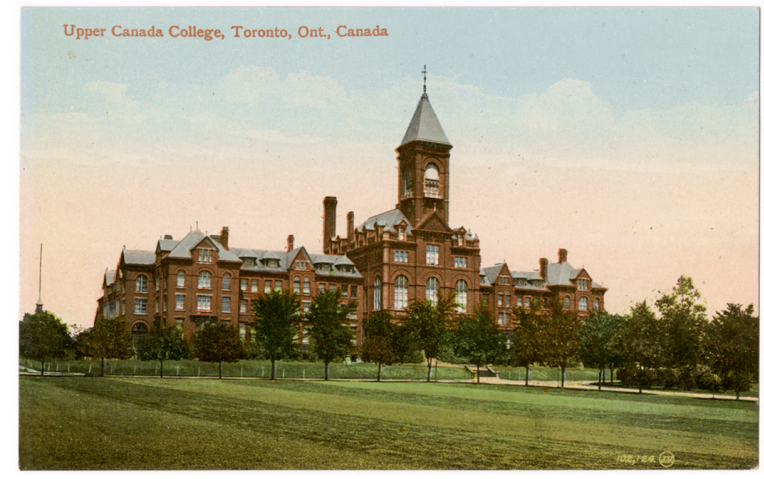

Recto

AGO Accession Number: 2011/253

Classification: Photography Collection Constituents:

Publisher: Valentine \& Sons Co. Ltd., Montreal and Toronto

Photographer: Unknown

Constituents Note: The Valentine \& Sons

Publishing Co. Ltd. was founded in

Montreal and Toronto in 1903 and 1906

respectively. Operations were terminated in 1923.

Title: Upper Canada College, Toronto, Ont., Canada

Title Note: Printed

Date(s) of Object: [between 1908 and 1923]

Date Notes: This card was printed after the Valentine \& Sons began to use the 'FAMOUS THROUGHOUT THE WORLD' trademark in 1908.

Object Name: Postcard

Medium: Letterpress halftone

Dimensions:

Image: $8.7 \times 13.9 \mathrm{~cm}, 3.43 \times 5.47$ in

Sheet: $8.7 \times 13.9 \mathrm{~cm}, 3.43 \times 5.47 \mathrm{in}$

Geography:

Place Created: Great Britain

Place Depicted: Avenue Road at

Lonsdale Avenue, Toronto, Ontario

Mark(s): recto: titled, [no.] 102,124 JV

[circled] l.r.; verso: publisher imprint, trademark, post template,

Inscriptions: None
Verso

Notes: Designed by George F. Durand (1850-1889) in the Romanesque Revival style and completed by Walter Reginald Strickland (1841-1915) and William Limbery Symons (1870-1931) upon Durrand's death, Upper Canada College constructed in 1889-91 was demolished in 1956. Construction of a new building including the reconstruction of the tower over the main entrance was completed in 1959.

Alternate Number: AG0.98718 


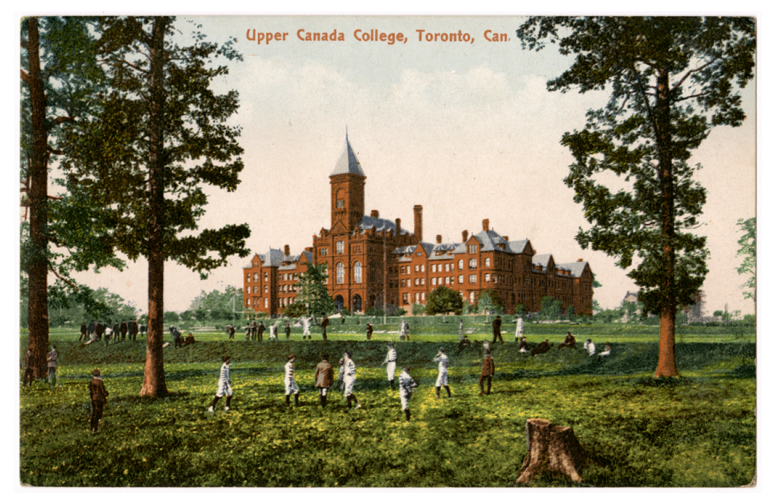

Recto

AGO Accession Number: 2011/254

Classification: Photography Collection Constituents:

Publisher: Toronto News Company, Toronto, Canada

Photographer: Unknown

Constituents Note: None

Title: Upper Canada College, Toronto, Can.

Title Note: Printed

Date(s) of Object: 1910

Date Notes: postmarked July 21, 1910

Object Name: Postcard

Medium: Chromolithograph

Dimensions:

Image: $8.8 \times 13.7 \mathrm{~cm}, 3.46 \times 5.39$ in

Sheet: $8.8 \times 13.7 \mathrm{~cm}, 3.46 \times 5.39$ in

Geography:

Place Created: Unknown

Place Depicted: Avenue Road at

Lonsdale Avenue, Toronto, Ontario

Mark(s): recto: titled; verso: publisher imprint, post template, [no.] 5700 l.l., Inscriptions: verso: in ink: Thurs. Eve. Dear M Got your letter to-day when I got home was so glad to get it. So Axel is till on earth and Gus \& Alf. Isn't that funny. Mr Schrieber doesn't forget about Mary eh! Ida Miss M. E. Harris Waubanik Ont; in graphite: CU2 l.r.

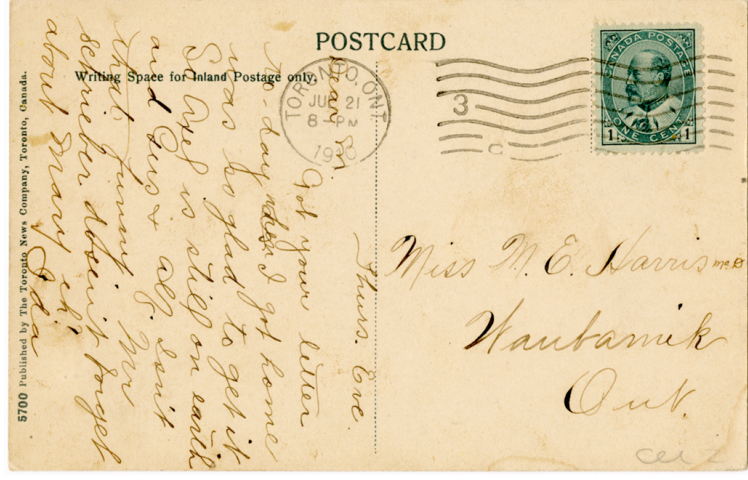

Verso

Notes: Designed by George F. Durand (1850-1889) in the Romanesque Revival style and completed by Walter Reginald Strickland (1841-1915) and William Limbery Symons (1870-1931) upon Durrand's death, Upper Canada College constructed in 1889-91 was demolished in 1956. Construction of a new building including the reconstruction of the tower over the main entrance was completed in 1959.

Alternate Number: AG0.98719 


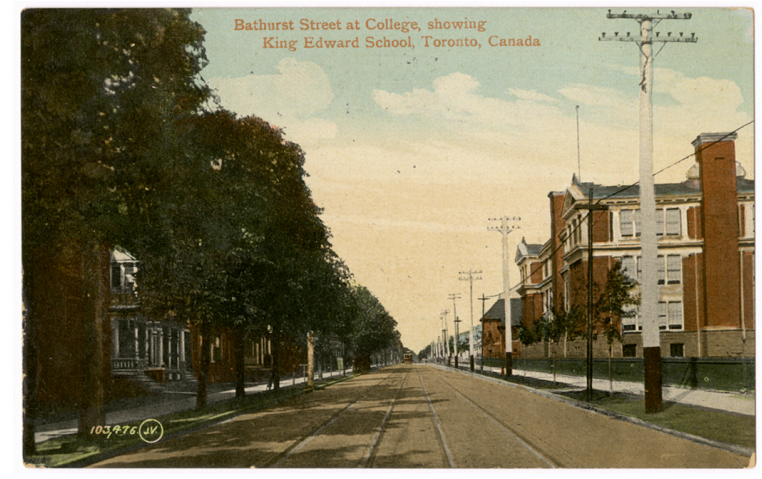

Recto

AGO Accession Number: 2011/255

Classification: Photography Collection Constituents:

Publisher: The Valentine \& Sons Co. Ltd., Montreal and Toronto

Photographer: Unknown

Constituents Note: The Valentine \& Sons

Publishing Co. Ltd. was founded in

Montreal and Toronto in 1903 and 1906

respectively. Operations were terminated in 1923.

Title: Bathurst Street at College, showing King Edward School, Toronto, Canada

Title Note: Printed

Date(s) of Object: 1912

Date Notes: The card is postmarked

December 21, 1912 and was printed after the Valentine \& Sons began to use the 'FAMOUS THROUGHOUT THE WORLD' trademark in 1908.

Object Name: Postcard

Medium: Letterpress halftone

Dimensions:

Image: $8.6 \times 13.6 \mathrm{~cm}, 3.39 \times 5.35$ in

Sheet: $8.6 \times 13.6 \mathrm{~cm}, 3.39 \times 5.35$ in

Geography:

Place Created: Great Britain

Place Depicted: 112 Lippincott Avenue,

Toronto, Ontario (near the northeast

corner of College and Bathurst Streets)

Mark(s): recto: titled, [no.] 103,476 JV

[circled] l.l.; verso: publisher imprint, trademark, post template,

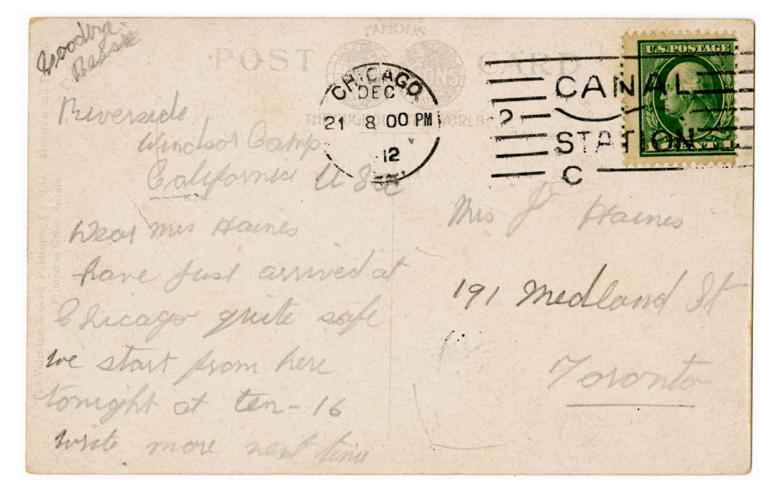

Verso

Inscriptions: verso: ink: Goodbye Bessie Riverside Windsor Camp California USA Dear Mrs Haines Have just

arrived at Chicago quite safe We start from here tonight at ten - 16 Write more next time Mrs J Haines 191 Midland St Toronto

Notes: Bathurst Street was named for Henry, the $3^{\text {rd }}$ Earl of Bathurst, Secretary of War for the Colonies from 1812-1827. College Street's name arises from an association with King's College, University of Toronto. King Edward School was constructed in 1901. Originally the Bathurst Street School, the school was renamed the King Edward School in honour of King Edward VII who ascended the throne in in 1902.

Alternate Number: AG0.98720 


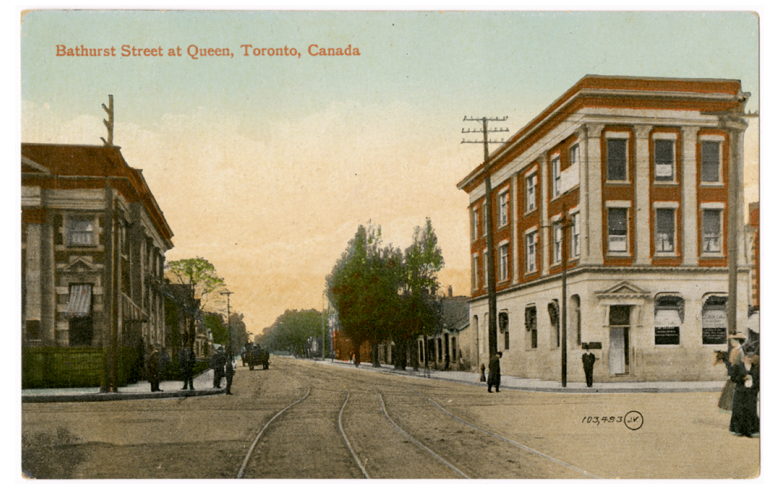

Recto

AGO Accession Number: 2011/256

Classification: Photography Collection Constituents:

Publisher: The Valentine \& Sons Co. Ltd., Montreal and Toronto

Photographer: Unknown

Constituents Note: The Valentine \& Sons Publishing Co. Ltd. was founded in Montreal and Toronto in 1903 and 1906 respectively. Operations were terminated in 1923.

Title: Bathurst Street at Queen, Toronto, Canada

Title Note: Printed

Date(s) of Object: 1910

Date Notes: The card is postmarked September 2, 1910 and was printed after the Valentine \& Sons began to use the 'FAMOUS THROUGHOUT THE WORLD' trademark in 1908.

Object Name: Postcard

Medium: Letterpress halftone

Dimensions:

Image: $8.7 \times 13.8 \mathrm{~cm}, 3.43 \times 5.43 \mathrm{in}$

Sheet: $8.7 \times 13.8 \mathrm{~cm}, 3.43 \times 5.43$ in

Geography:

Place Created: Great Britain

Place Depicted: Intersection of

Bathurst Street and Queen Street West looking north

Mark(s): recto: titled, [no.] 103,483 JV [circled] l.r.; verso: publisher imprint, trademark, post template,

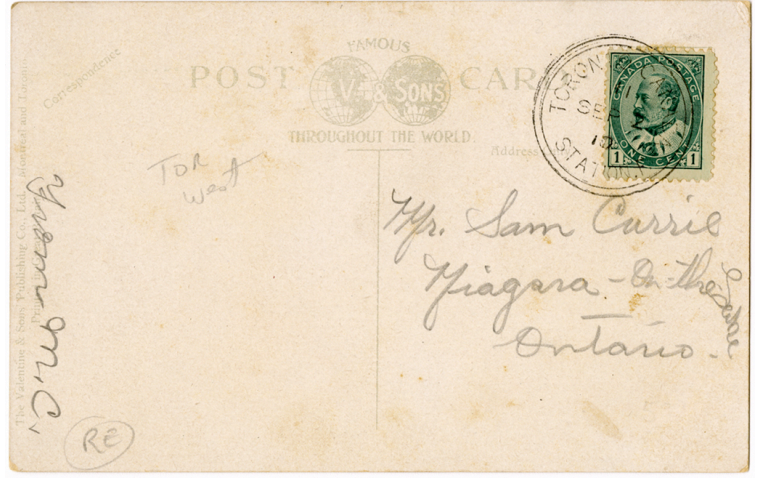

Verso

Inscriptions: verso: in graphite: From M. C. Mr. Sam Currie Niagara-On-The-Lake Ontario., TOR West, t.l.; in graphite: RE [circled] l.l.

Notes: Bathurst Street was named for Henry, the $3^{\text {rd }}$ Earl of Bathurst, Secretary of War for the Colonies from 1812-1827. Prior to 1870 Bathurst Street north of Queen Street was known as Crookshank's Lane after the Honourable George Crookshank (1773-1859)

Alternate Number: AGO-98721 


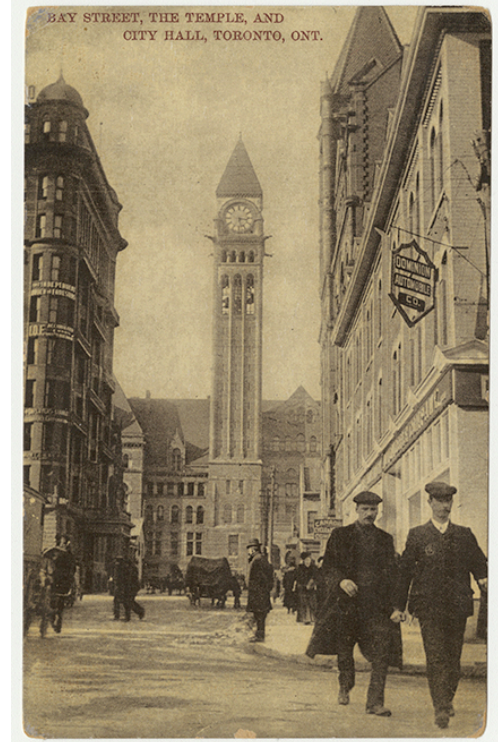

Recto

AGO Accession Number: 2011/257

Classification: Photography Collection Constituents:

Publisher: Unknown

Photographer: Unknown

\section{Constituent Note:}

Title: Bay Street, The Temple and City

Hall, Toronto, Ont.

Title Note: Printed

Date(s) of Object: 1908

Date Notes: postmarked July 23, 1908

Object Name: Postcard

Medium: Collotype

Dimensions:

Image: $13.7 \times 8.6 \mathrm{~cm}, 5.39 \times 3.39$ in

Sheet: $13.7 \times 8.6 \mathrm{~cm}, 5.39 \times 3.39 \mathrm{in}$

\section{Geography:}

Place Created: Unknown

Place Depicted: Bay Street, looking north towards City Hall

Mark(s): recto: titled; verso: post template

Inscriptions: verso: in ink: Dear Aunt Min, We are going to Lorain to-morrow. I am on the boat now. I am not feeling well. Was awful sick. your Dear little Irene R. Miss Minnie Miller 538 Vine St. Johnstown Pa.; in graphite: club l.l.

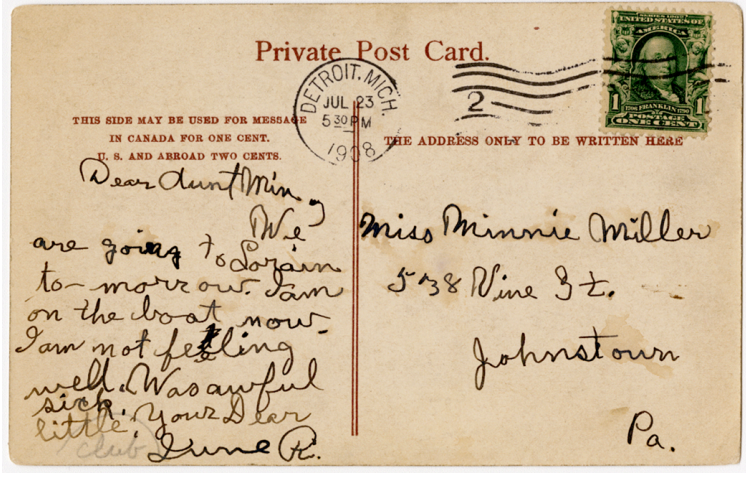

Verso

Notes: Bay Street was named in 1797 when the town of York first reset its boundaries. Designed by architect George William Gouinlock (1861-1932) for the Independent Order of Foresters, the Temple Building was constructed in 1895-97 and demolished in 1970. It was one of the first skyscrapers built in Toronto. Designed by architect Edward James Lennox (1855-1933) in the "Richardson Romanesque" style, City Hall was constructed in 1890-99. The building is presently used as a provincial courthouse.

Alternate Number: AG0.98722 


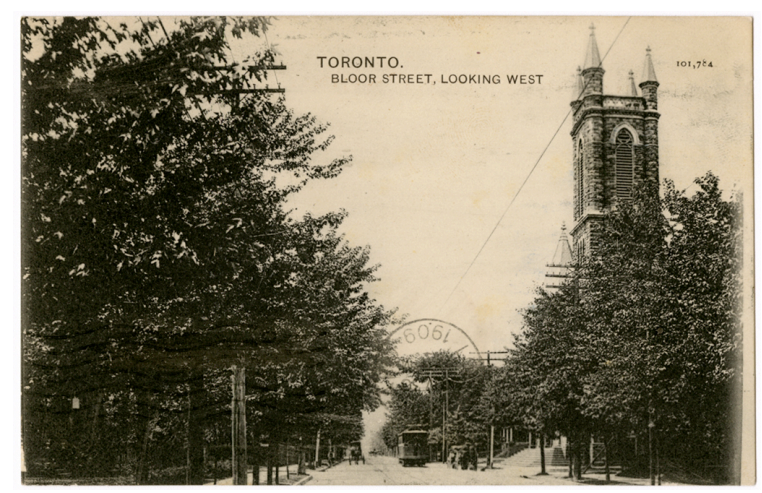

Recto

AGO Accession Number: 2011/258

Classification: Photography Collection Constituents:

Publisher: The Valentine \& Sons Co. Ltd., Montreal and Toronto

Photographer: Unknown

Constituents Note: The Valentine \& Sons Publishing Co. Ltd. was founded in Montreal and Toronto in 1903 and 1906 respectively. Operations were terminated in 1923.

Title: TORONTO, BLOOR STREET, LOOKING WEST

Title Note: Printed

Date(s) of Object: [between 1903 and 1908]

Date Notes: The card is postmarked November 30, 1909This card was printed prior to when Valentine \& Sons began to use the 'FAMOUS THROUGHOUT THE WORLD' trademark in 1908.

Object Name: Postcard

Medium: Collotype

Dimensions:

Image: $8.8 \times 13.8 \mathrm{~cm}, 3.46 \times 5.43 \mathrm{in}$

Sheet: $8.8 \times 13.8 \mathrm{~cm}, 3.46 \times 5.43$ in

\section{Geography:}

Place Created: Great Britain

Place Depicted: Bloor Street at Huron

Street, Toronto, Ontario looking west

Mark(s): recto: titled, [no.] 101,784 t.r.; verso: publisher imprint, post template

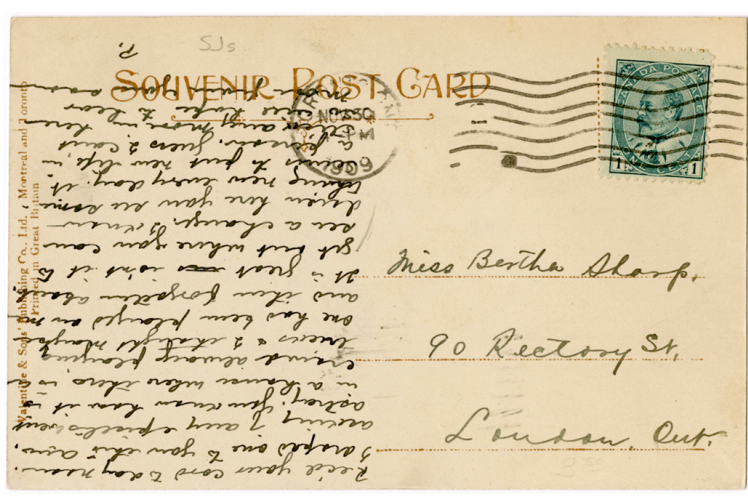

Verso

Inscriptions: verso: in ink: Rec'd your card today noon. I droped (sic) one to you this am asking if any epistles went astray. You know how it is in a house where there is a crowd always playing tricks \& I thought maybe one has been played on me and thus forgotten about. It is great isn't it to get out where you can see a change. I know down here you see some thing new every day. It serves to put new life in a person. Guess I can't stick any more in here so will hope to hear more from you soon. P. Miss Bertha Sharp 90 Rectory St. London, Ont.; in graphite: SJs t.l.

Notes: Bloor Street was named after Joseph Bloore (1789-1862) a successful brewer in 1855. The Bloor Street Presbyterian Church is seen on the right side of the postcard. Designed by architect William Rufus Gregg (18511930) it was constructed in 1889-90. Alternate Number: AG0.98723 


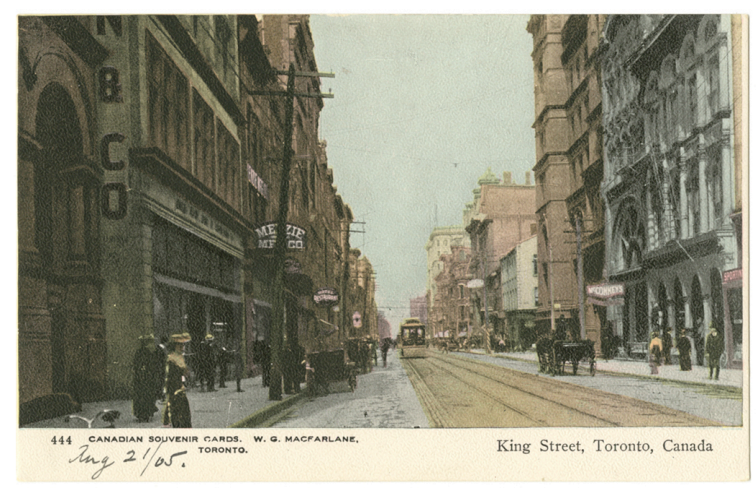

Recto

AGO Accession Number: 2011/259

Classification: Photography Collection

Constituents:

Publisher: W. G. MacFarlane Publishing Co. Ltd. Toronto

Photographer: Unknown

Constituents Note: The W. G. MacFarlane Publishing Co. Ltd. Toronto maintained offices in Toronto commencing in 1899 and published postcards between 1902 and 1910.

Title: King Street, Toronto, Canada

Title Note: Printed

Date(s) of Object: 1905

Date Notes: postmarked August 21, 1905

Object Name: Postcard

Medium: Letterpress halftone

Dimensions:

Image: $7.9 \times 14.0 \mathrm{~cm}, 3.11 \times 5.51 \mathrm{in}$

Sheet: $8.9 \times 14.0 \mathrm{~cm}, 3.50 \times 5.51$ in

Geography:

Place Created: Toronto, Ontario

Place Depicted: King Street looking east

Mark(s): recto: titled, publishers imprint, trademark 'Canadian Souvenir Cards', [no.] 444 l.l.; verso: post template Inscriptions: recto, in ink: Aug 21/05. L.l.; verso: in graphite: [no.] 881 [circled] t.l.

Notes: King Street is named after King George III (b. 1738, r.1760-1820) and was one of the first streets to be designated in the town of York.

Alternate Number: AG0.98724

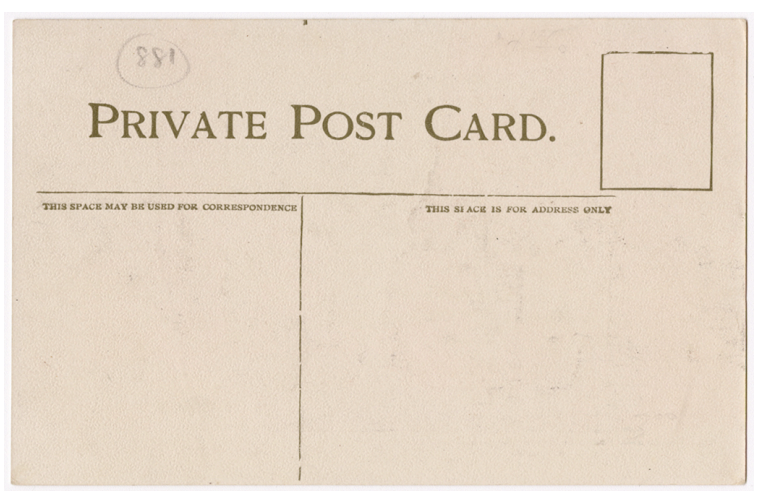

Verso 


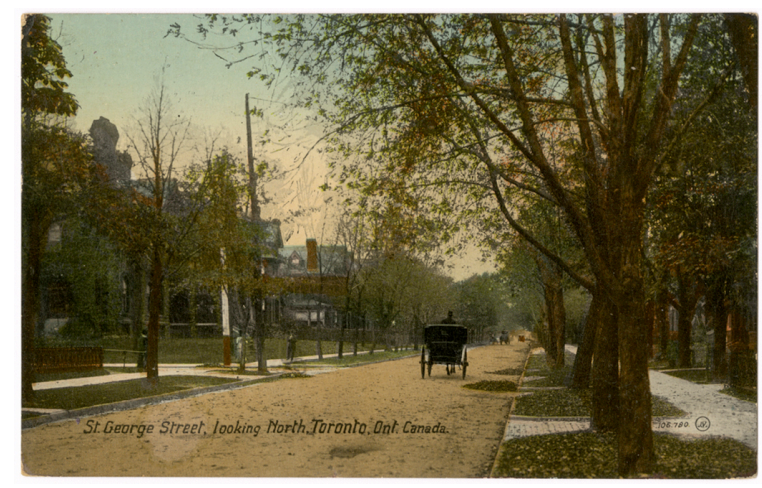

Recto

AG0 Accession Number: 2011/260

Classification: Photography Collection

Constituents:

Publisher: The Valentine \& Sons Co.

Ltd., Montreal and Toronto

Photographer: Unknown

Constituents Note: The Valentine \& Sons

Publishing Co. Ltd. was founded in

Montreal and Toronto in 1903 and 1906

respectively. Operations were terminated in 1923.

Title: St. George Street, looking North, Toronto, Ont. Canada.

Title Note: Printed

Date(s) of Object: [between 1908 and 1912]

Date Notes: The card is postmarked June 6,1912 . This card was printed after the Valentine \& Sons began to use the 'FAMOUS THROUGHOUT THE WORLD' trademark in 1908.

Object Name: Postcard

Medium: Letterpress halftone

Dimensions:

Image: $8.5 \times 13.5 \mathrm{~cm}, 3.35 \times 5.31 \mathrm{in}$

Sheet: $8.5 \times 13.5 \mathrm{~cm}, 3.35 \times 5.31 \mathrm{in}$

Geography:

Place Created: Great Britain

Place Depicted: A view of George

Street looking north from Bloor

Street

$\operatorname{Mark(s):~recto:~titled,~[no.]~} 106.780 \mathrm{JV}$

[circled] l.r.; verso: publisher imprint, trademark, post template, stamp,

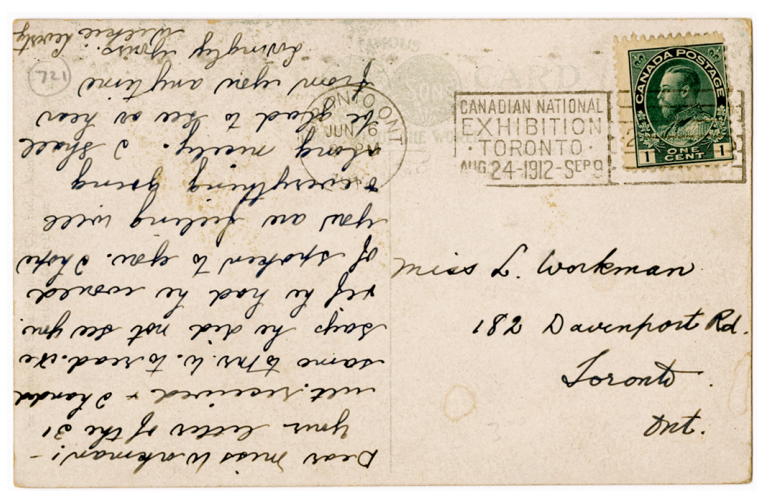

Verso

CANADIAN NATIONAL EXHIBITION TORONTO AUG 24-1912-SEP 9 t.r.

Inscriptions: verso: in ink: Dear Miss

Workman! - your letter of the $31^{\text {st }}$ received \& I handed same to $\mathrm{Mr}$. W. to read. He says he did not see you \& if he had he would of spoken to you. I hope you are feeling well \& everything going along nicely. I shall be glad to see or hear from you anytime Lovingly yours. Wilkie Leverty Miss L. Workman 182 Davenport $\mathrm{Rd}$. Toronto Ont.; in graphite: [no.] 721 [circled] t.l.

Notes: St. George Street was named after the successful businessman Laurent Quetton St. George (1771-1821).

Alternate Number: AG0.98725 


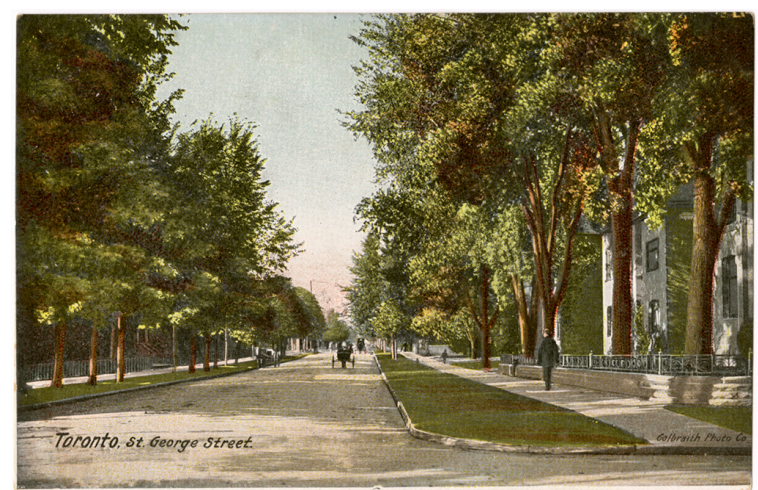

Recto

AGO Accession Number: 2011/261

Classification: Photography Collection Constituents:

Publisher: W. J. Gage and Co. Ltd., Toronto

Photographer: Alexander W. Galbraith Constituents Note: W. J. Gage and Co. Ltd. was founded in 1880 by William Gage and produced stationary and books. The company was destroyed by fire in 1904 and was rebuilt in 1906. Alexander W. Galbraith (1867-1950) was a commercial photographer in Toronto from 1899 to 1924.

Title: Toronto, St. George Street Title Note: Printed Date(s) of Object: [after 1903]

Date Notes: Postal Regulations in Canada allowed for divided postcards in 1903.

Object Name: Postcard

Medium: Letterpress halftone

Dimensions:

Image: $9.0 \times 14.0 \mathrm{~cm}, 3.54 \times 5.51$ in

Sheet: $9.0 \times 14.0 \mathrm{~cm}, 3.54 \times 5.51 \mathrm{in}$

Geography:

Place Created: Unknown

Place Depicted: A view of George Street looking north from Bloor Street Mark(s): recto: titled, photographers imprint 'Galbraith Photo Co.; verso: publishers imprint, post template, [no.] 1784 t.l.

Inscriptions: verso: in graphite: HF, t.l.

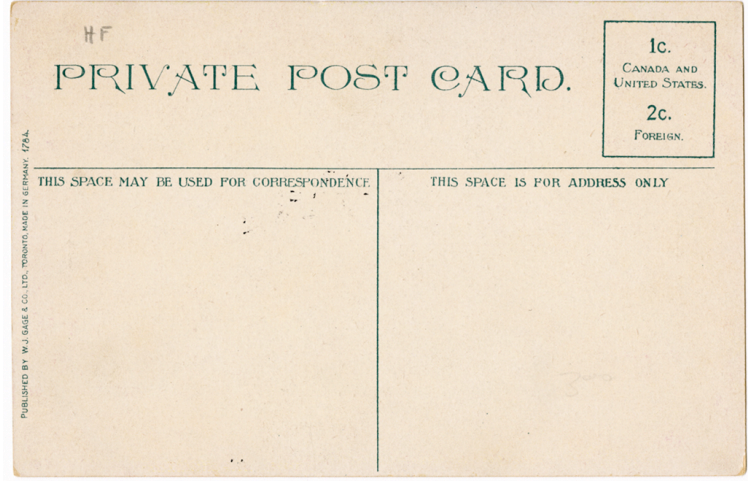

Verso

Notes: St. George Street was named after the successful businessman Laurent Quetton St. George (1771-1821).

Alternate Number: AG0.98726 


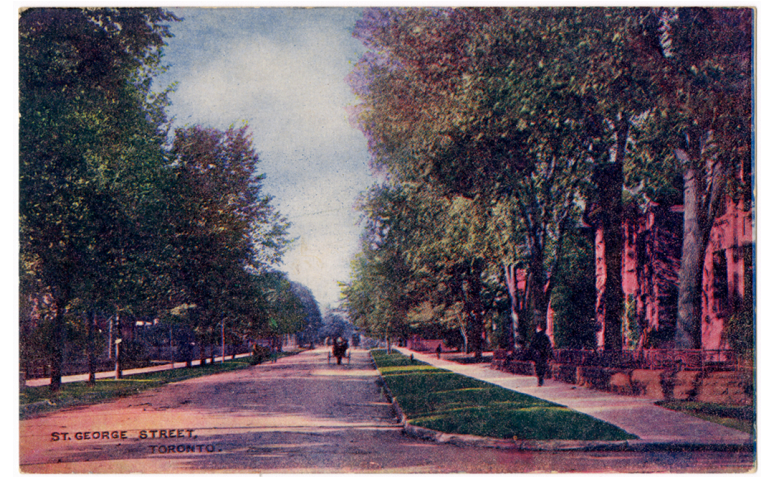

Recto

AGO Accession Number: 2011/262

Classification: Photography Collection

\section{Constituents:}

Publisher: The Canadian View Card Co., Toronto

Photographer: Alexander W. Galbraith Constituents Note: The Canadian View

Card Co. published postcards at the beginning of the twentieth century in Toronto. Alexander W. Galbraith (18671950) was a commercial photographer in Toronto from 1899 to 1924.

Title: St. George Street, Toronto.

Title Note: Printed

Date(s) of Object: [1910s]

Date Notes: None

Object Name: Postcard

Medium: Letterpress halftone

Dimensions:

Image: $8.7 \times 13.8 \mathrm{~cm}, 3.43 \times 5.43$ in

Sheet: $8.7 \times 13.8 \mathrm{~cm}, 3.43 \times 5.43 \mathrm{in}$

Geography:

Place Created: Unknown

Place Depicted: A view of George Street looking north from Bloor Street

Mark(s): recto: titled; verso: publishers imprint, trademark 'PRIVATE-POST-

CARD', post template

Inscriptions: verso: in graphite: squiggly line l.r.

Notes: St. George Street was named after the successful businessman Laurent Quetton St. George (1771-1821).

Alternate Number: AG0.98727

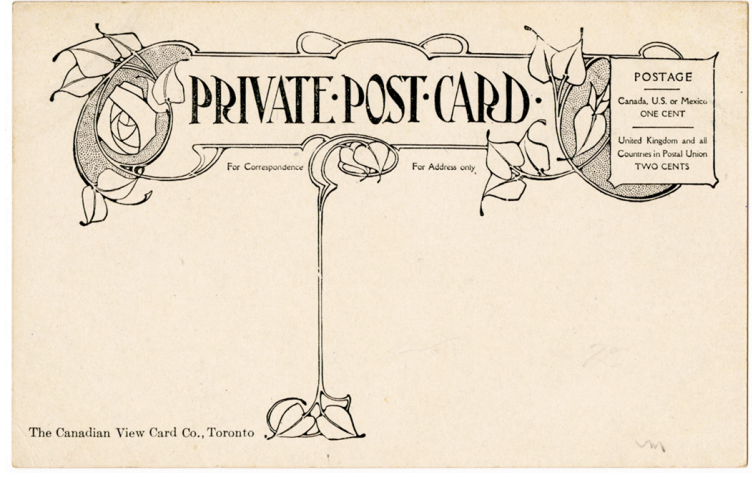

Verso 


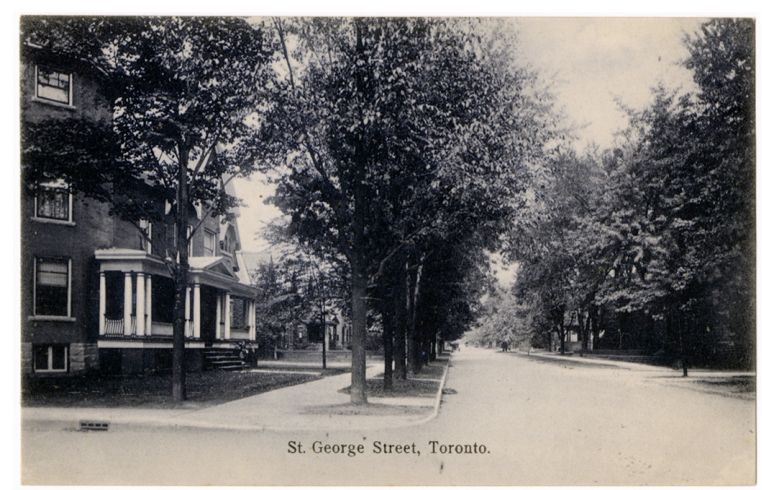

Recto

AG0 Accession Number: 2011/263

Classification: Photography Collection Constituents:

Publisher: W. G. MacFarlane Publishing Co. Ltd. Toronto, New York, and Buffalo Photographer: Unknown

Constituents Note: The W. G. MacFarlane Publishing Co. Ltd. Toronto maintained offices in Toronto commencing in 1899 and published postcards between 1902 and 1910.

Title: St. George Street, Toronto.

Title Note: Printed

Date(s) of Object: [between 1903 and 1910]

Date Notes: Canadian Postal regulations allowed divided postcards in 1903 and the W. G. MacFarlane Publishing Co. Ltd. published postcards between 1902 and 1910

Object Name: Postcard

Medium: Collotype

Dimensions:

Image: $8.7 \times 13.7 \mathrm{~cm}, 3.43 \times 5.39 \mathrm{in}$

Sheet: $8.7 \times 13.7 \mathrm{~cm}, 3.43 \times 5.39$ in

Geography:

Place Created: Toronto, Ontario

Place Depicted: A view of St. George

Street

Mark(s): recto: titled; verso: publisher imprint, post template, [no.] E. 169 l.l. Inscriptions: verso: in graphite: [no.] 2159 [circled] l.r.

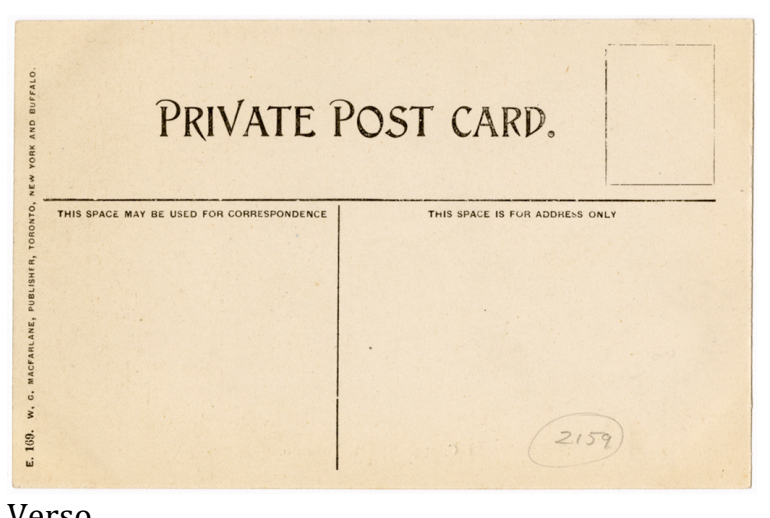

Verso

Notes: St. George Street was named after the successful businessman Laurent Quetton St. George (1771-1821).

Alternate Number: AG0.98728 


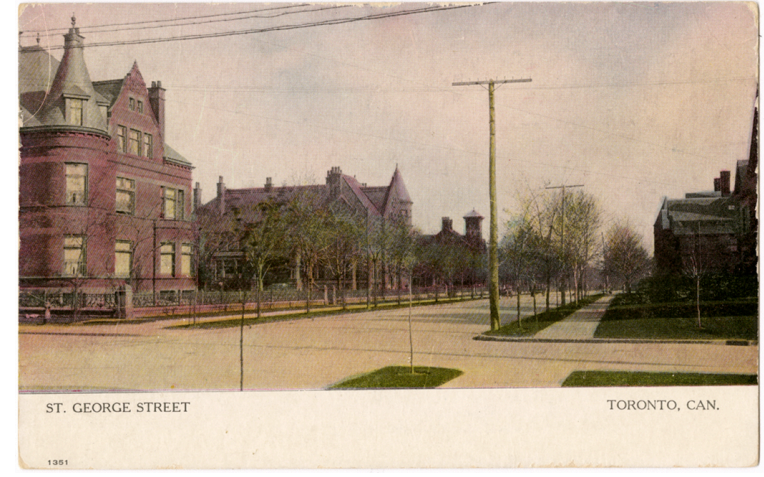

Recto

AGO Accession Number: 2011/264

Constituents:

Publisher: Warwick Bro's \& Rutter, Limited, Publishers, Toronto

Photographer: Unknown

Constituents Note: Warwick Bro's \&

Rutter, Limited maintained operations in

Toronto from 1860 to 1972 and

published postcards between 1903 and

1912

Title: St. George Street - Toronto, Can.

Title Note: Printed

Date(s) of Object: [between 1903 and 1912]

Date Notes: Canadian Postal regulations allowed divided postcards in 1903.

Warwick Bro's \& Rutter, Limited, Publishers produced postcards from 1903

to 1912

Object Name: Postcard

Medium: Letterpress halftone

Dimensions:

Image: $7.4 \times 14.0 \mathrm{~cm}, 2.91 \times 5.51 \mathrm{in}$

Sheet: $8.9 \times 14.0 \mathrm{~cm}, 3.50 \times 5.51$ in

Geography:

Place Created: Toronto, Ontario

Place Depicted: A view of St. George

Street

Mark(s): recto: titled, [no.] 1351 l.l.;

verso: publishers imprint, trademark

'Canadian Souvenir Post Card', post

template

Inscriptions: verso: in graphite: York 2

l.l.

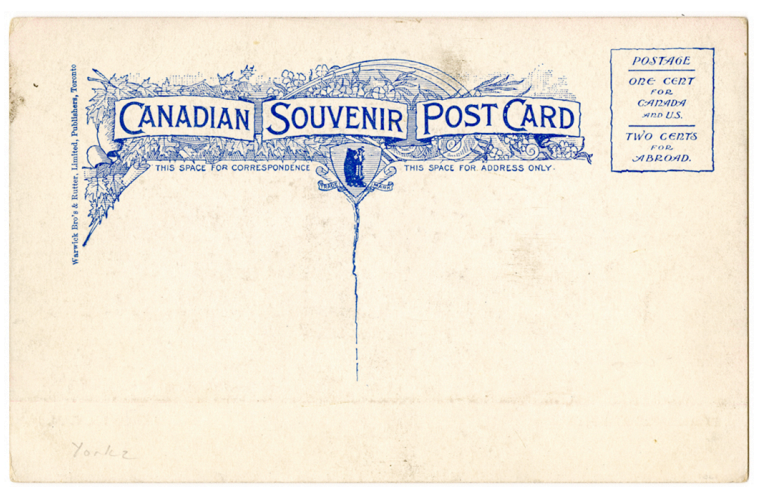

Verso

Notes: St. George Street was named after the successful businessman Laurent Quetton St. George (1771-1821). Alternate Number: AGO.98729 


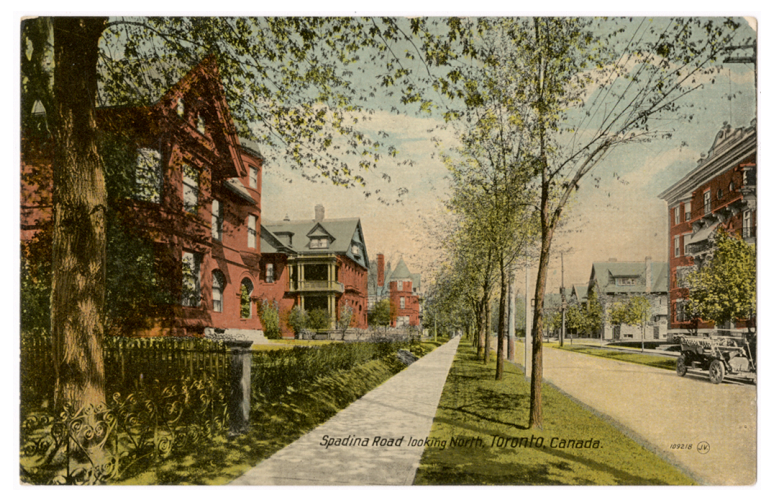

Recto

AGO Accession Number: 2011/265

Classification: Photography Collection

Constituents:

Publisher: The Valentine \& Sons Co.

Ltd., Montreal, Toronto and Winnipeg

Photographer: Unknown

Constituents Note: The Valentine \& Sons

Publishing Co. Ltd. was founded in

Montreal and Toronto in 1903 and 1906

respectively. Operations were terminated in 1923.

Title: Spadina Road looking North,

Toronto, Canada

Title Note: Printed

Date(s) of Object: [between 1908 and 1923]

Date Notes: This card was printed after

Valentine \& Sons began to use the 'FAMOUS THROUGHOUT THE WORLD' trademark in 1908.

Object Name: Postcard

Medium: Letterpress halftone

Dimensions:

Image: $8.9 \times 13.8 \mathrm{~cm}, 3.50 \times 5.43 \mathrm{in}$

Sheet: $8.9 \times 13.8 \mathrm{~cm}, 3.50 \times 5.43$ in

Geography:

Place Created: U.S.A.

Place Depicted: A view of Spadina

Road looking north

Mark(s): recto: titled, [no.] $109218 \mathrm{JV}$

[circled] l.r.; verso: publisher imprint, trademark, post template,

Inscriptions: verso: in graphite: [no.] 142

[circled] l.r.

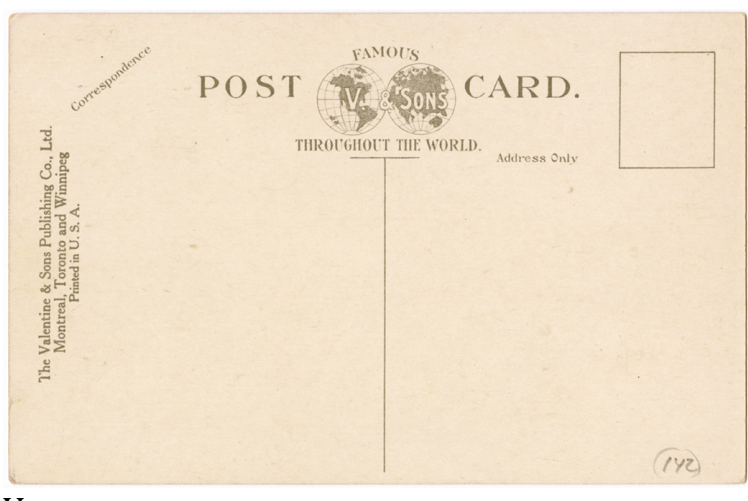

Verso

Notes: Dr. William Warren Baldwin constructed Spadina Road in 1836 and named it after his house on the hill just east of where Casa Loma is located.

Spadina (then pronounced Spadeena) is derived from the Native word "espadinong" meaning hill.

Alternate Number: AG0.98730 


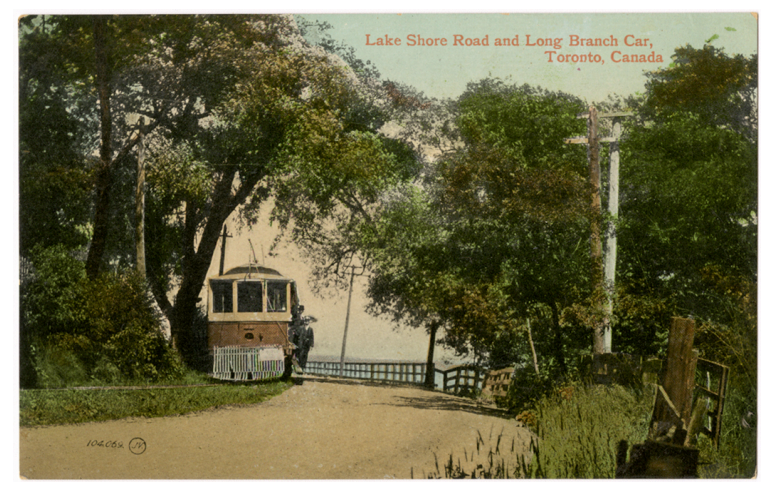

Recto

AGO Accession Number: 2011/266

Classification: Photography Collection Constituents:

Publisher: The Valentine \& Sons Co. Ltd., Montreal, Toronto and Winnipeg

Photographer: Unknown

Constituents Note: The Valentine \& Sons

Publishing Co. Ltd. was founded in

Montreal and Toronto in 1903 and 1906

respectively. Operations were terminated in 1923.

Title: Lake Shore Road and Long Branch Car, Toronto, Canada

Title Note: Printed

Date(s) of Object: [between 1908 and 1923]

Date Notes: This card was printed after Valentine \& Sons began to use the 'FAMOUS THROUGHOUT THE WORLD' trademark in 1908.

Object Name: Postcard

Medium: Letterpress halftone

Dimensions:

Image: $8.7 \times 13.7 \mathrm{~cm}, 3.43 \times 5.39$ in

Sheet: $8.7 \times 13.7 \mathrm{~cm}, 3.43 \times 5.39$ in

Geography:

Place Created: Great Britain

Place Depicted: Long Branch loop the most western portion of the Toronto

Transit Commission streetcar line Mark(s): recto: titled, [no.] 104069. JV [circled] 1.l.; verso: publisher imprint, trademark, post template,

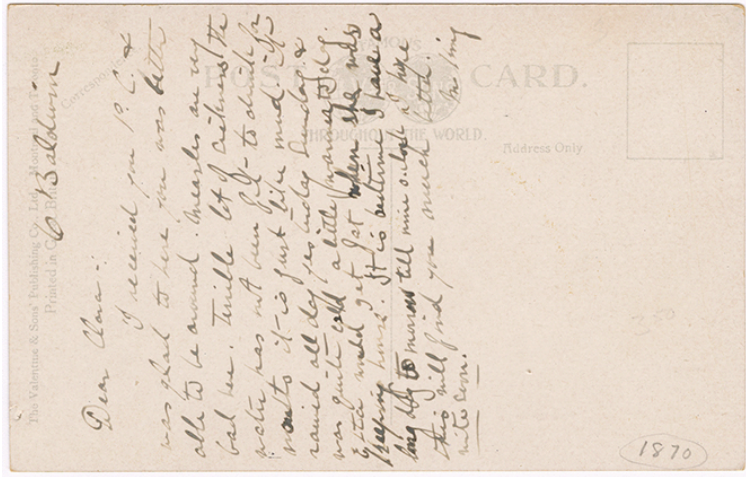

Verso

Inscriptions: verso: in ink: 6 Baldwin Dear Clara, I received you P. C. \& was glad to here you was better able to be around. Measles are very bad here. Terrible lot of sickness the water has not been good to drink for months it is just like mud. It rained all day yesterday Sunday \& was quite cold a little warmer today Etta would get [unreadable] when she was keeping house. It is bedtime I have a long day tomorrow till nine oclock I hope this will find you much better Write soon. M [unreadable] King; in graphite: [no.] 1870 [circled] l.r.

Notes: West of the Humber River, Lake Shore Road built in 1921 connected the City of Toronto with the former Village of Long Branch part of the former Township of Etobicoke. The Long Branch streetcar transported commuters from the Humber Loop in the east with the Long Branch Loop in the west.

Alternate Number: AG0.98731 


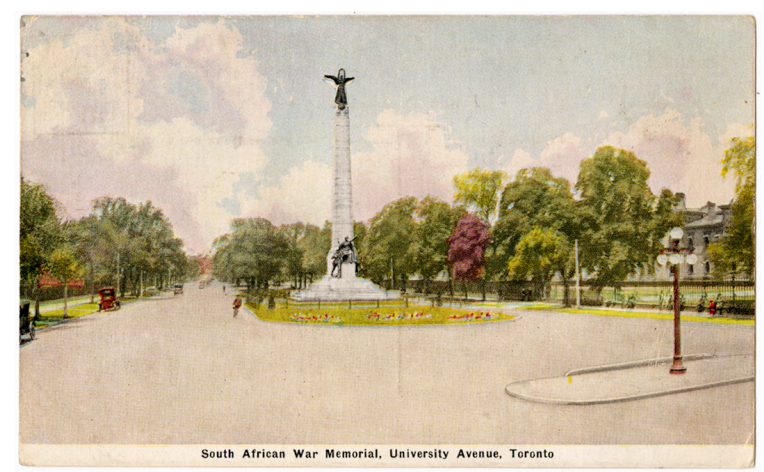

Recto

AGO Accession Number: 2011/267

Classification: Photography Collection Constituents:

Publisher: Gardiner, Thomson \&

Bowles

Photographer: Unknown

Constituents Note: none

Title: South African War Memorial,

University Avenue, Toronto

Title Note: Printed

Date(s) of Object: 1924

Date Notes: postmarked July 28, 1924

Object Name: Postcard

Medium: Letterpress halftone

Dimensions:

Image: $8.1 \times 13.9 \mathrm{~cm}, 3.19 \times 5.47 \mathrm{in}$

Sheet: $8.5 \times 13.9 \mathrm{~cm}, 3.35 \times 5.47 \mathrm{in}$

\section{Geography:}

Place Created: Canada

Place Depicted: University Avenue and Queen Street West, Toronto, Ontario looking north

Mark(s): recto: titled; verso: publisher imprint, [no.] 6682, post template, stamp 'VISIT POSTAL-EXHIBIT-TORONTO EXHIBITION AUG 23 TO SEP 1924

Inscriptions: verso: in ink: Toronto 930 am Monday Making good time all OK in haste to get train in 10 minutes Margaret Misses M \& J Aberud 22 Goemfedar Buffalo N. Y. U. S. A.; in graphite: [no.] 2816 (?) [circled] l.l.

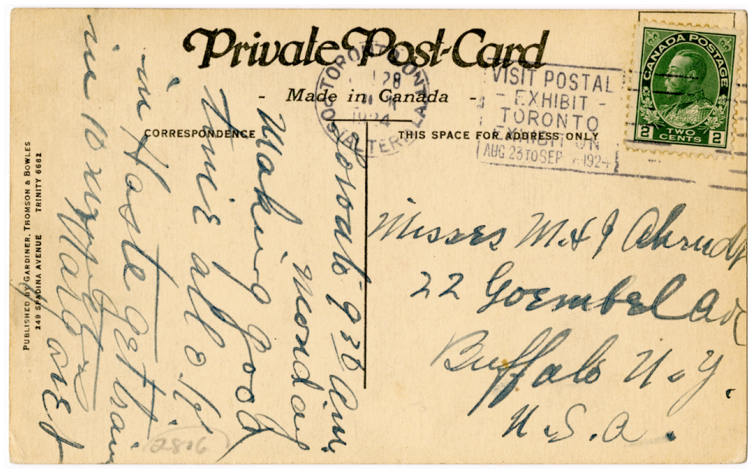

Verso

Notes: The memorial commemorates Canada's participation in the second Boer War (1899-1902). It was commissioned by banker James Mason (1843-1918) and designed by Walter Seymour Allward (1876-1955). It was unveiled in 1908 and was restored in 2001.

Alternate Number: AG0.98732 


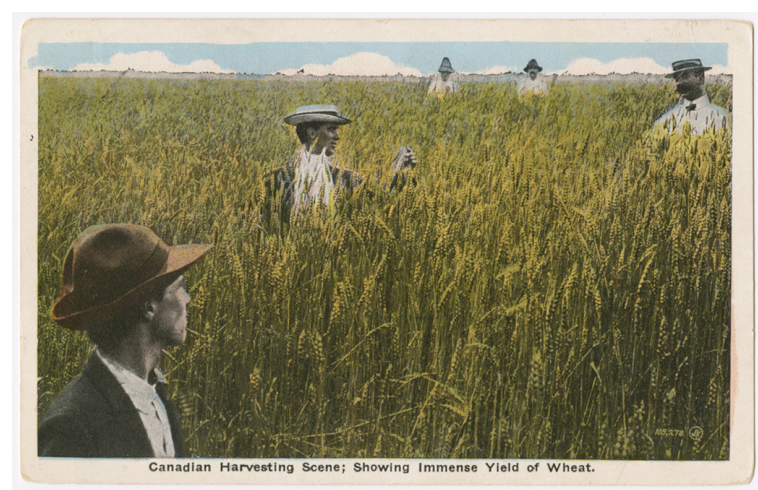

Recto

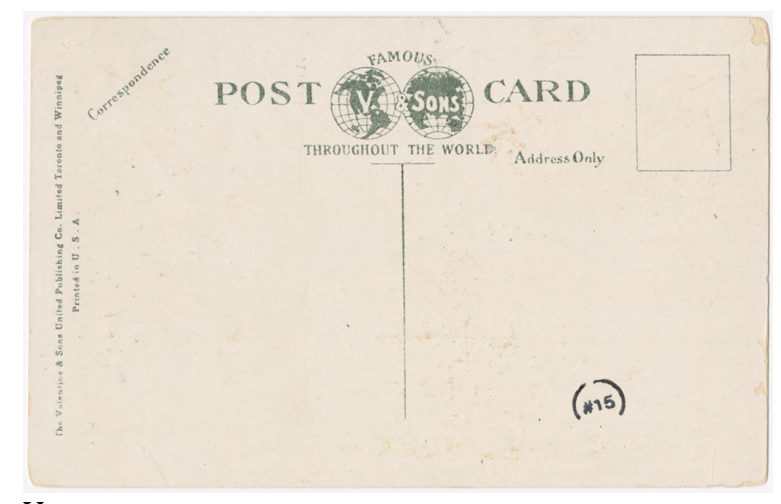

Verso

AGO Accession Number: 2011/268

Classification: Photography Collection

Constituents:

Publisher: The Valentine \& Sons Co.

Ltd., Montreal, Toronto and Winnipeg

Photographer: Unknown

Constituents Note: The Valentine \& Sons

Publishing Co. Ltd. was founded in

Montreal and Toronto in 1903 and 1906

respectively. Operations were terminated in 1923.

Title: Canadian Harvesting Scene; Showing Immense Yield of Wheat

Title Note: Printed

Date(s) of Object: [between 1915 and 1923]

Date Notes: Postcards with a white border first appeared in 1915 and Valentine \& Sons ceased operations in 1923.

Object Name: Postcard

Medium: Letterpress halftone

Dimensions:

Image: $7.9 \times 13.2 \mathrm{~cm}, 3.11 \times 5.20 \mathrm{in}$

Sheet: $8.9 \times 14.0 \mathrm{~cm}, 3.50 \times 5.51 \mathrm{in}$

Geography:

Place Created: U. S. A.

Place Depicted: Unknown

Mark(s): recto: titled, [no.] 105,278 JV

[circled] l.r.; verso: publisher imprint, trademark, post template

Inscriptions: verso: stamp in black ink [no.] \#15 [circled]

Notes: None

Alternate Number: AG0.98733 


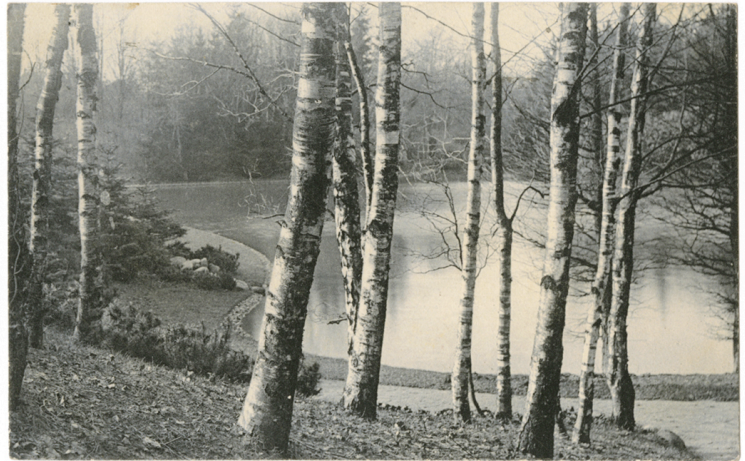

Recto

AGO Accession Number: 2011/269

Classification: Photography Collection Constituents:

Publisher: Warwick Bro's \& Rutter, Limited, Publishers, Toronto

Photographer: Unknown

Constituents Note: Warwick Bro's \&

Rutter, Limited maintained operations in Toronto from 1860 to 1972 and published postcards between 1903 and 1912

Title: [Birch trees by pond]

Title Note: Descriptive

Date(s) of Object: 1908

Date Notes: This card is postmarked March 16, 1908

Object Name: Postcard

Medium: Collotype

Dimensions:

Image: $8.6 \times 13.7 \mathrm{~cm}, 3.39 \times 5.39$ in

Sheet: $8.6 \times 13.7 \mathrm{~cm}, 3.39 \times 5.39$ in

Geography:

Place Created: Germany

Place Depicted: pending further research the site could be Grenadier Pond, High Park looking west

Mark(s): verso: publisher imprint, trademark 'Canadian Souvenir Post Card', post template

Inscriptions: veso, in ink: Mar. 15/08 Dear Bella, Could you come to the lecture at College St. Church on Tuesday, I would meet you at door of church at about 5 or 10 minutes to eight. Is it a collection only? Yours sincerely N. Laidlaw Miss

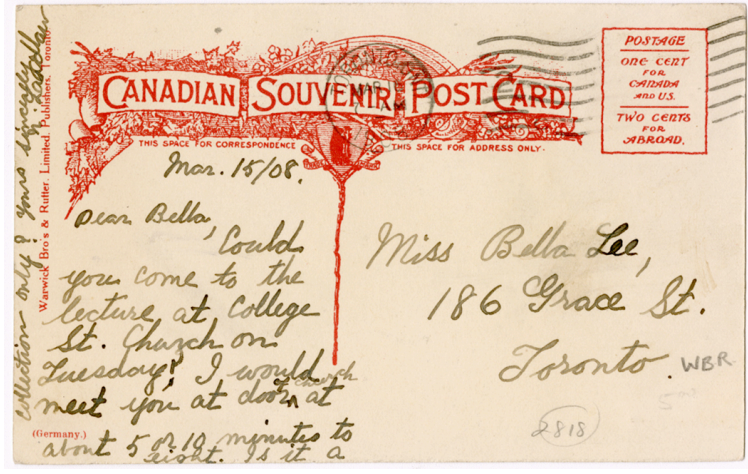

Verso

Bella Lee, 186 Grace St. Toronto; WBR l.r.; in graphite: [no.] 2818 [circled] l.r.

Notes: None

Alternate Number: AGO.98734 


\section{Appendix 1: List of Publishers of AGO Postcards}

1. Advertising Dept. Walker House - W.F.W.

2. A.L. Merrill

3. The B. C. Printing \& Litho Ltd.

4. The Canadian View Card Co.

5. Dept. Of Publicity, Canadian National Exhibition

6. Douglas Ford Toronto, Publisher

7. W. J. Gage \& Co. Ltd.

8. Gardiner, Thomson \& Bowles

9. Henry Garner - Living Picture Post Card Co. (H G L)

10. Kiwanis Club of West Toronto Inc.

11. Novelty and Art Manufacturing Co.

12. Photogelatin Engraving Co. Ltd.

13. Picture Postcard Co.

14. Postcard \& Greeting Card Co. Ltd.

15. The Pugh Manufacturing Co.

16. The Richmond Sales Co. Ltd.

17. Royal Specialty Sales Co.

18. Southam Press Ltd.

19. Souvenir Post Card Co.

20. Toronto Convention \& Tourist Assn.

21. Toronto News Company

22. Valentine-Black Co. Ltd.

23. The Valentine \& Sons Co. Ltd.

24. W. G. MacFarlane Publisher \& Importer

25. Walter M. Lowney Co. of Canada Ltd.

26. Warwick Bro's \& Rutter Ltd. Printers

27. E. Zaitchick, Canadian National Exhibition

(the publishers for six postcards are unknown) 


\section{Appendix 2: List of Photomechanical Reproductive Processes}

\section{Chromolithography}

The chromolithographic process involved the printing of multiple colours employing multiple plates. Each plate contained a printable image transferred from paper and etched. The stone is then inked with the selected colour and printed in register with a "key" plate. Stones allowed for solid areas of colour and stippling (large dot pattern). Detail is visible in solid colours and areas where the dot pattern diffuses the colour. Two overlaid transparent colours can produce a third colour.

\section{Collotype}

The collotype shares with lithography the incompatibility of oil and water to describe the printing surface. Unlike lithography the collotype plates employ a reticulated gelatin coating to produce an image derived from a continuous-tone negative. The collotype plate moved underneath a series of ink rollers and under a cylinder holding the paper the image was to be deposited on. As the cylinder came into contact with the printing plate a single impression of ink is transferred to the paper. Colour collotypes can be achieved with the use of three-colour separation negatives to produce three collotype plates and registered multiple printing. Colour can also be added using stencils and applying paints over the stencils by hand.

\section{Gravure}

The gravure process combines etching and aquatint to produce an image similar to a carbon print. A polished copper plate is dusted with acid resistant grains similar to the aquatint process. Carbon/gelatin tissue with red pigment is sensitized to light and exposed to a film or glass plate to produce a positive image. This carbon/gelatin image is then pressed to the copper plate, the tissue is removed with the use of hot water and the plate is etched using ferric chloride in water transferring the image to the copper plate. The absorption of water by the gelatin permits the ferric chloride to etch the dark and light areas of the image. When the plate is finished etching the resist and aquatint are removed. The plate now displays a set of pits that have been etched inversely proportional to the thickness of the gelatin layer. When inked the plate reveals continuous tonality. Photogravures are produced using flat plates while rotogravures employ a series of cylinders to ink and transport paper for the image to be transferred. 


\section{Letterpress Halftone}

The letterpress halftone process commences with the production of a halftone negative of an original image through a ruled screen of tiny apertures. When exposed to a sensitized plate and developed in a high contrast developer, these tiny apertures produce dots of various sizes in relation to the intensity of illumination by the original. The halftone negative is contacted printed onto a light-sensitive resist deposited on a copper plate. The resist is hardened where exposed to light and is soft where the resist is unexposed. The plate is washed and the soft resist is removed. The plate is then etched in an acid bath dissolving area where the copper plate is bare between the dots. The undercutting of the copper plate by the acid diminished the size of the dots resulting in a lighter print.

\section{Photo Offset Lithography}

Having its origins in chromolithography, photo offset lithography employs metal plates and the refinement of the halftone screen to reproduce the photographic image. The process involved the transfer of an image on an inked metal plate to a rubber blanket and then onto paper with the use of three cylinders arranged above each other. The photo offset lithographic process allows for 300 dots per linear inch producing an image with finer tonal gradation unlike the letterpress halftone limited to 150 dots per linear inch. 


\section{Bibliography}

Anderson, Allan \& Betty Tomlinson, Greetings from Canada: An Album of Unique Canadian Postcards from the Edwardian Era 1900-1916. Toronto: Macmillan of Canada, 1978.

Allen, Rodney F. and Laurie E. S. Molina, "People and Places on Picture Postcards: A HighInterest Source for Geographic Education," Journal of Geography 91, no. 3 (1992): 106112.

Arreola, Daniel D., "La Cerca y Las Garitas de Ambos Nogales: A Postcard Landscape Exploration," Journal of the Southwest, 43, no. 4, Border Cities and Culture (Winter, 2001): 505-541.

Arreola, Daniel D. \& Nick Burkhart "Photographic Postcards and Visual Urban Landscape," Urban Geography 31, no. 7 (2010): 885-904.

Arthur, Eric. Toronto: No Mean City. Toronto: University of Toronto Press, 1986.

Bassnett, Sarah, "Visuality and the Emergence of City Planning in Early Twentieth-Century Toronto and Montreal." Journal of the Society for the Study of Architecture in Canada, 32, 1 (2007): 21-38.

- - - "Picturing the Professionalization of Planning in Canada, 1901-1927," Journal of the Society for the Study of Architecture in Canada, 33, no. 2 (2008): 21-32.

Benson, Richard. The Printed Picture. New York: Museum of Modern Art, 2008.

Biographical Dictionary of Architects in Canada 1800 - 1950, http://www.dictionaryofarchitectsincanada.org/

Carline, Richard. Pictures in the Post: The Story of the Picture Postcard. London: Gordon Fraser, 1971.

Canadian National Exhibition Archive, http://www.cnearchives.com/

City of Toronto Archives, "A Commercial City at the Beginning of the 20th Century", http://www.toronto.ca/culture/history/history-1901-50.htm

Collins, Karen. "Providing Subject Access to Images: A Study of User Queries," The American Archivist 61, (1998): 36-55.

Dating-AU: Technology, Photography and Architecture $19^{\text {th }}-20^{\text {th }}$ www.dating-au.com/valentine-james-and-sons/

Dendy, William. Lost Toronto. Toronto: McClelland \& Stewart Inc., 1978. 
Dendy, William \& William Kilbourn. Toronto Observed: Its Architecture, Patrons, and History, Toronto: Oxford University Press, 1986.

Enser, Peter, "The Evolution of Visual Information Retrieval." Journal of Information Science, 34, (2008): 531-546.

Filey, Mike. Wish You Were Here: Great Postcards of Early Toronto, Toronto: Greey de Pencier Publications, 1977.

Kaellgren, Peter, “Omar Ramsden and the CNE”, Material History Review, 46 (Fall 1997): 1728

Lorimer, James. The Ex: A Picture History of the Canadian National Exhibition. Toronto: James Lewis \& Samuel, Publishers, 1973.

Mackinnon, Steve, Karen Teeple \& Michele Dale, Toronto's Visual Legacy: Official City Photography From 1856 to the Present, Toronto: James Lorimer \& Company, 2009.

Metropolitan Postcard Club of New York, http://www.metropostcard.com/

Nus, Walter Van, “The Fate of City Beautiful Thought in Canada, 1893-1930”, in Stelter, Gilbert A. and Alan F. J. Artibise ed., The Canadian City: Essays in Urban and Social History, Ottawa: Carleton University Press, 1991, 167-186.

Once Upon a Century: 100 Year History of the Ex., Toronto: J. H. Robinson Publishing Ltd., 1978.

Phillips, Glen C., The Ontario Photographers List 1901-1925, Volume Two, Milton, Ontario: Global Heritage Press, 2010.

Rogan, Bjarne, "An Entangled Object: The Picture Postcard as Souvenir and Collectible, Exchange and Ritual Communication." Cultural Analysis 4, (2005): 1-27.

Ruthford, Paul, “Tomorrow's Metropolis: The Urban Reform Movement in Canada, 18801920," in Stelter, Gilbert A. and Alan F. J. Artibise ed., The Canadian City: Essays in Urban and Social History, Ottawa: Carleton University Press, 1991, 435-455.

Sawyer, Carol F. \& David R. Butler, "The Use of Historical Picture Postcards as Photographic Sources for Examining Environmental Change: Promises and Problems," Geocarto International 21, No. 3 (September 2006): 73-80.

Scherer, Joanna C., “The Photographic Document: Photographs as Primary Data in Anthropological Enquiry," in Edwards, Elizabeth ed., Anthropology \& Photography 1860-1920, New Haven: Yale University Press, 1992, 32-41. 
Shatford Layne, Sara, "Some Issues in the Indexing of Images." Journal of the American Society for Information Science 458 (1994): 583-588.

Smith, Michael J. Warwick Bros. \& Rutter Postcard Gems, 1903-1912. Goderich: Michael J. Smith and W.O. (Bill) Buchanan, 2011.

——, The W.G. MacFarlane Picture Postcard Handbook, 1902-1910. Goderich: M.J. Smith, 2010.

Staff, Frank. The Picture Postcard and Its Origins. New York: Frederick A. Praeger, 1966.

Statistics Canada, Toronto 150: Portrait of a Changing City: Government of Canada, 1984.

Stelter, Gilbert A. and Alan F. J. Artibise ed., The Canadian City: Essays in Urban and Social History, Ottawa: Carleton University Press, 1991.

Strong, David, Sidney Carter (1880-1956) and the Politics of Pictorialism, (Masters thesis). Montreal: Concordia University, 1994.

Toronto Postcard Club (TPC), http://torontopostcardclub.com/

Vintage Postcards of Hamilton, Ontario, http://www.hamiltonpostcards.com/

Woody, Howard, "International Postcards: Their History, Production, and Distribution (Circa 1895 to 1915)" Delivering Views: Distant Cultures in Early PostcardsI, Greary, Christraud M, \& Virginia-Lee Webb ed., Washington: Smithsonian Institution Press, 1998, 13-45. 
Illustration Credits

Plates in Catalogue courtesy of the Art Gallery of Ontario.

Additional plates courtesy of the Toronto Reference Library. 